\title{
Soil Investigation of Lower East Fork Poplar Creek
}

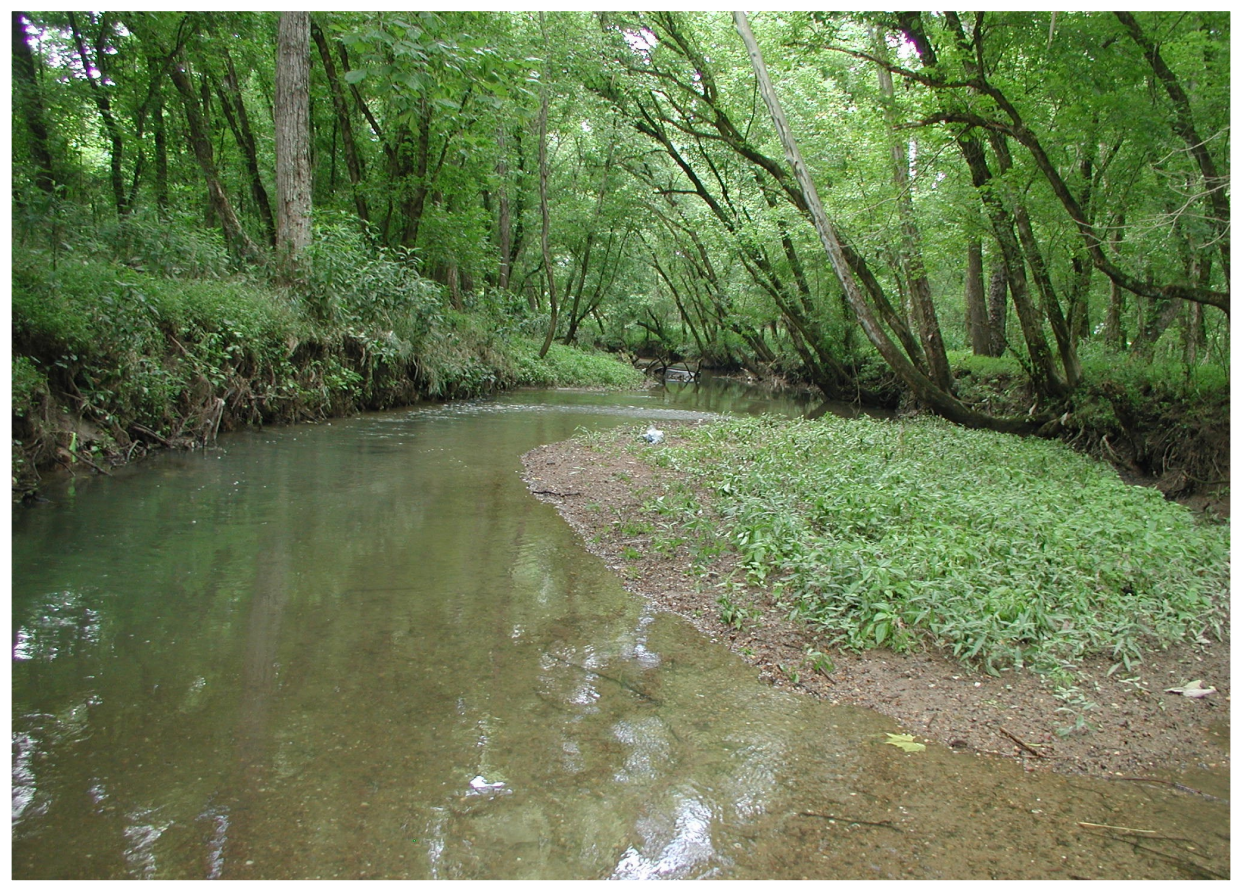

Approved for public release. Distribution is unlimited.
Johnbull Dickson Melanie Mayes Jennifer Earles Tonia Mehlhorn Kenneth Lowe Mark Peterson Eric Pierce

August 2015 


\section{DOCUMENT AVAILABILITY}

Reports produced after January 1, 1996, are generally available free via US Department of Energy (DOE) SciTech Connect.

Website http://www.osti.gov/scitech/

Reports produced before January 1, 1996, may be purchased by members of the public from the following source:

National Technical Information Service
5285 Port Royal Road
Springfield, VA 22161
Telephone 703-605-6000 (1-800-553-6847)
TDD 703-487-4639
Fax 703-605-6900
E-mail info@ntis.gov
Website http://www.ntis.gov/help/ordermethods.aspx

Reports are available to DOE employees, DOE contractors, Energy Technology Data Exchange representatives, and International Nuclear Information System representatives from the following source:

Office of Scientific and Technical Information

PO Box 62

Oak Ridge, TN 37831

Telephone 865-576-8401

Fax 865-576-5728

E-mail reports@osti.gov

Website http://www.osti.gov/contact.html

This report was prepared as an account of work sponsored by an agency of the United States Government. Neither the United States Government nor any agency thereof, nor any of their employees, makes any warranty, express or implied, or assumes any legal liability or responsibility for the accuracy, completeness, or usefulness of any information, apparatus, product, or process disclosed, or represents that its use would not infringe privately owned rights. Reference herein to any specific commercial product, process, or service by trade name, trademark, manufacturer, or otherwise, does not necessarily constitute or imply its endorsement, recommendation, or favoring by the United States Government or any agency thereof. The views and opinions of authors expressed herein do not necessarily state or reflect those of the United States Government or any agency thereof. 
Environmental Sciences Division

\title{
SOIL INVESTIGATION OF LOWER EAST FORK POPLAR CREEK
}

\author{
Johnbull Dickson \\ Melanie Mayes \\ Jennifer Earles \\ Tonia Mehlhorn \\ Kenneth Lowe \\ Mark Peterson \\ Eric Pierce
}

Date Published: August 2015

Prepared by

OAK RIDGE NATIONAL LABORATORY

Oak Ridge, TN 37831-6283

managed by

UT-BATTELLE, LLC

for the

US DEPARTMENT OF ENERGY

under contract DE-AC05-00OR22725 



\section{CONTENTS}

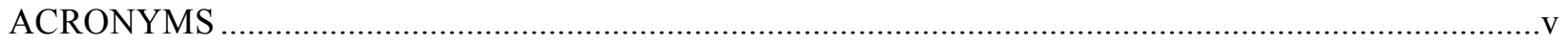

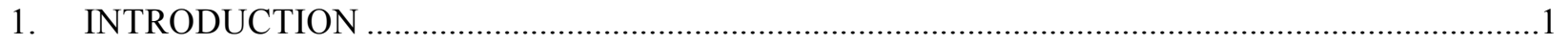

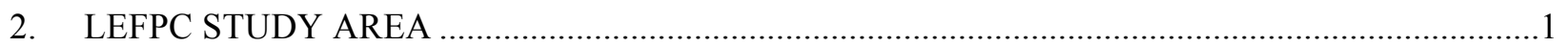

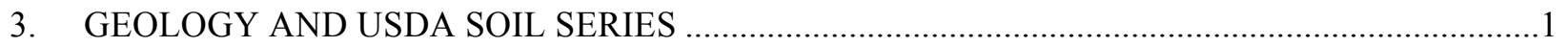

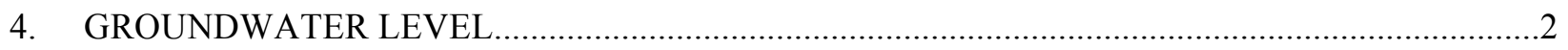

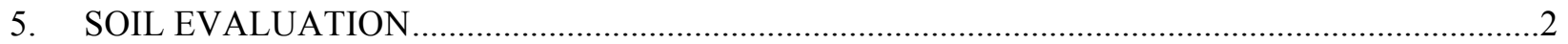

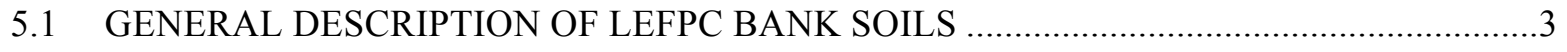

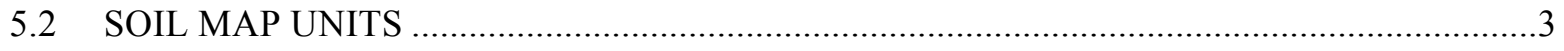

5.2.1 Fluvaquentic Dystrudepts (Chenneby Series) ...........................................................

5.2.2 Fluvaquentic Eutrudepts (Hamblen Series) ............................................................

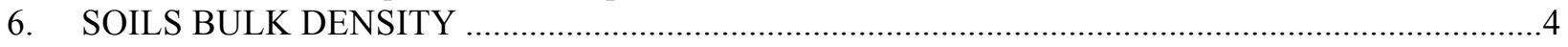

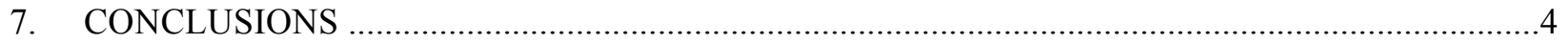

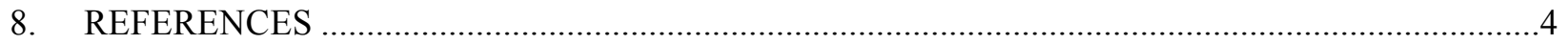

APPENDIX A. SOIL MAPS SHOWING THE DISTRIBUTION OF SOIL MAP UNITS ALONG

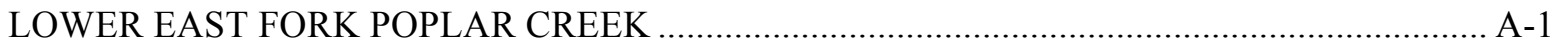

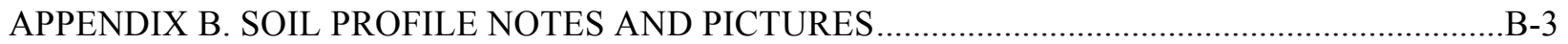

APPENDIX C. BULK DENSITY SUMMARY TABLE .................................................................. 



\section{ACRONYMS}

BGS below ground surface

DOE US Department of Energy

EFPC East Fork Poplar Creek

LEFPC lower East Fork Poplar Creek

USDA US Department of Agriculture

Y-12 Y-12 National Security Complex 



\section{INTRODUCTION}

Mercury is regarded by the US Department of Energy (DOE) Oak Ridge Office of Environmental Management as a priority contaminant on the Oak Ridge Reservation because of the environmental risks associated with substantial losses from buildings, soils, and surface waters at the Y-12 National Security Complex (Y-12). As a result of historical releases of mercury from Y-12 primarily in the 1950s and early 1960 s, the lower East Fork Poplar Creek (LEFPC) stream channel and bank soil margins are contaminated with mercury (Brooks and Southworth 2011; Tennessee Valley Authority 1985b, a).

A Mercury Remediation Technology Development project is underway to evaluate the nature of downstream mercury contamination and to develop targeted site-specific remedial technologies that can mitigate mercury release and biological uptake. It is known that mercury concentration varies longitudinally and with depth in LEFPC bank soils; however, soil types and soil physical properties are not well known, especially relative to the zones of mercury contamination. Moreover, there are no soil maps for the downstream reaches of LEFPC in Roane County (i.e. from the Chestnut Hill Road downstream) and this work represents the first ever soil mapping along this section of LEFPC.

Purpose and Scope: The aim of this report is to present the results of a field investigation of bank soil characteristics within the $18 \mathrm{~km}$ reach of LEFPC, through detailed physical descriptions and mapping. As more information becomes available on mercury concentrations in bank soils, the soil physical properties will be important in the development and application of technologies such as bank stabilization techniques, chemical treatment, or use of sorbents. Bank soils have different properties that may enhance or limit mercury release to the stream and future remedial options may be targeted to those areas with the highest mercury release.

Approach/Method: The bank soil investigation-conducted from May 11 to June 5, 2015-involved walking the entire $18 \mathrm{~km}$ LEFPC reach and mapping soil horizons encountered on the creek bank faces. Before soil characterization was performed, the bank surface was cleared of vegetation and other debris to expose the soil profile. Sixty-nine soil profile descriptions were completed along the entire reach of the creek. An additional 21 soil samples were collected for bulk density determination.

\section{LEFPC STUDY AREA}

LEFPC is located in the EFPC watershed within the city of Oak Ridge in Anderson and Roane Counties in the Appalachian Valley and Ridge Physiographic Province of eastern Tennessee. Within Y-12 EFPC is bounded to the north by Pine Ridge and Chestnut Ridge to the south, while in East Fork valley LEFPC is bounded to the north by Black Oak Ridge and East Fork Ridge to the south. The EFPC watershed drains an area of approximately $76.5 \mathrm{~km}^{2}$ extending from the headwaters to the mouth at Poplar Creek. The elevations within the watershed range from 230 to $290 \mathrm{~m}$ above mean sea level. EFPC originates within the Bear Creek Valley underlying Y-12 and flows in a northeasterly direction until crossing a water gap in Pine Ridge and exiting the Y-12 perimeter. LEFPC refers to the locations downstream of the Y-12 Complex. After the water gap, LEFPC turns toward the northwest, paralleling Tennessee State Route 62 through commercial developments within the city of Oak Ridge. At the intersection of Tennessee State Routes 62 and 95 in Oak Ridge, the creek drains southwesterly toward Poplar Creek. The width of the 100 -year flood plain bordering this creek ranges from several meters in the upper areas to approximately $500 \mathrm{~m}$ in the downstream reaches. The lower reaches of the flood plain (beyond the intersection of Tennessee State Routes 62 and 95) are mostly undeveloped woodlands and pasture with some residential developments. 


\section{GEOLOGY AND USDA SOIL SERIES}

According to Geology of Eastern Tennessee, published by the US Geological Survey (Hardeman, Miller, and Swingle 1966; Hatcher 1987), LEFPC is situated in the Appalachian Valley and Ridge Physiographic Province of eastern Tennessee, characterized by ridges and valleys that strike toward the northeast and southwest. The valleys are typically derived from limestone and shale, whereas the ridges are typically developed from sandstone and cherty dolomite. Because of many strike-parallel local and regional thrust faults in the valley and ridge, southeast trending beds are common features. The sedimentary deposits that underlie the LEFPC are Cambrian- to Ordovician-age sediments of the Rome and Chickamauga Formations. The Rome Formation is characterized as a maroon to gray, micaceous shale interbedded with sandstone and siltstone (Carmichael 1989), whereas the Chickamauga is a gray to blue-gray, shalely to silty limestone with occasional occurrence of sinkholes.

The thickness of the alluvial deposits underlying the site and overlying the bedrock ranges from zero at the floodplain boundary with exposed bedrock to approximately $3 \mathrm{~m}$ at the center of the floodplain. The $0.3-1.5 \mathrm{~m}$ thick alluvial soils of the floodplain comprise mainly silt and clay with a lesser amount of sands. These soils are classified as moderately well drained Hamblen silt loam and somewhat poorly drained Chenneby silt loam, with 0-3\% slopes (USDA 2015).

\section{GROUNDWATER LEVEL}

Based on the observation well data reported by Carmichael (1989) in the eastern portion of LEFPC, depths to water table ranged from approximately 0.31 to $1.22 \mathrm{~m}$ below ground surface (BGS) in late winter to early spring and 0.61 to $2.13 \mathrm{~m}$ BGS in summer and fall. The seasonal high water table generally occurred during the late fall and early spring because of increased precipitation and a large decrease in evapotranspiration.

The field mapping of bank soils was conducted during May and June 2015. Based on precipitation data recorded by the National Oceanic and Atmospheric Administration for Oak Ridge, Tennessee, cumulative precipitation (46 years) was $8.64 \mathrm{~mm}$ above normal (average) for the period of January 1, 2014, through December 31, 2014, and was $3.56 \mathrm{~mm}$ below normal for the months of January 1, 2015, through April 30, 2015. The normal annual precipitation for Oak Ridge from January through December is approximately $1,400 \mathrm{~mm}$ (NOAA 2015). Depth to surface water observed within LEFPC in May 2015 ranged from approximately 0.76 to $2.44 \mathrm{~m} \mathrm{BGS}$ over the evaluated portion of the creek. Thus, it is likely that the LEFPC surface water levels observed during this soil investigation represent normal seasonal high groundwater table fluctuations for summer to early fall.

\section{SOIL EVALUATION}

The LEFPC bank soils were mapped from May 11 through June 5, 2015, and consisted of visual inspection of creek bank surfaces, removal of vegetation and debris from surfaces with trowels and machetes to expose soil horizons, and description of profiles at 69 LEFPC bank locations. See Appendix A for approximate soil boring locations.

The soils encountered at these locations were classified in accordance with the USDA textural classification method. The soil profile evaluations are summarized in the Soil Profile Notes in Appendix B.

The soils were delineated based on drainage limitations, estimated permeability, and soil taxonomy. Soil conditions include soil permeability, depth to limiting zones encompassing zones of seasonal or perennial 
saturation, or a stratum that effectively limits the movement of water. Limiting zones may consist of dense or clayey strata that restrict the movement of water vertically through the soil profile, potentially resulting in seasonal saturation at shallow depths, sometimes referred to as a perched water table. The depth and degree of seasonal saturation may vary depending on the amount of precipitation from season to season and year to year. Redoximorphic features - soil colors due to the process of reduction, translocation, and oxidation of iron and manganese oxides (Vepraska 1999) - that form in response to repeated and prolonged saturation in the soil are generally used to estimate limiting zones, irrespective of where the groundwater table may be observed at any given time.

\subsection{GENERAL DESCRIPTION OF LEFPC BANK SOILS}

The evaluated LEFPC bank soils generally are characterized by fine silty to clayey alluvial materials of variable thickness underlain by gleyed, silty clay to clayey horizons. The Chickamauga bedrock is generally are encountered below this horizon.

Redoximorphic features indicative of a seasonal high water table or slow soil permeability (perched water table) were observed at depths ranging from 1.0 to $2.0 \mathrm{ft}$ BGS in these soils. Free water was observed in LEFPC at depths ranging from 30 to 96 in. BGS, which is in good agreement with groundwater levels reported by Carmichael (1989).

Based on soil characteristics described in the soil profile notes in Appendix B, soil taxonomy, and drainage limitations, two interpretive soil map units were delineated within the LEFPC site as follows: Fluvaquentic Dystrudepts and Fluvaquentic Eutrudepts.

\subsection{SOIL MAP UNITS}

\subsubsection{Fluvaquentic Dystrudepts (Chenneby Series)}

\subsubsection{Description}

The Chenneby soil unit occupies floodplains and depressions on gentle to slight slopes. These are deep (from 30 to $70 \mathrm{in}$.), somewhat poorly drained, moderately permeable soils formed in silty, 3- to 6-ft thick alluvial material weathered from sedimentary rock (limestone, sandstone, and shale). These soils are occasionally or frequently flooded for a brief period. The surface horizons of this unit are typically 6 in. thick and composed of a brown to dark brown mineral horizon of loam to silty clay loam. These horizons transition to a subsurface horizon (B horizon), a zone of color or structure development greater than $30 \mathrm{in}$. thick. The B horizon is underlain by a gray to olive yellow loamy parent material. Redoximorphic features indicative of a seasonal high groundwater table generally are encountered in these soils from 12 to 30 in. BGS.

\subsubsection{Findings}

The somewhat poorly drained Chenneby soil map unit within the LEFPC generally was composed of a loamy to silt loam surface horizon, to depths ranging from 6 to 18 in. BGS. These soils transition to a silt loam to clay loam subsurface horizon to depths ranging from 20 to $48 \mathrm{in}$. BGS. Underlying this horizon is the parent or geologic material consisting of gleyed silty clay loam to clay to depths of 36 to greater than 84 in. BGS.

Redoximorphic features indicative of seasonally saturated conditions were observed at depths ranging from 8 to 18 in. BGS, and free water levels observed in those parts of the creek occupied by this soil unit ranged from depths of 32 to 86 in. BGS. Based on observed soil textures, measured bulk density, and 
USDA saturated hydraulic conductivity classes $\left(K_{\text {sat }}\right)$, the permeability of these soils is moderate to moderately slow $(0.20-2.00 \mathrm{in} . / \mathrm{h})$ within the surficial alluvial material but slow to very slow $(<0.06 \mathrm{in} . / \mathrm{h})$ in the underlying clayey sediments. It should be noted that some areas under this mapping unit may qualify as wetlands.

\subsubsection{Fluvaquentic Eutrudepts (Hamblen Series)}

\subsubsection{Description}

The Hamblen are soils of floodplains and depressions, occupying gentle to slight slopes. These are very deep, moderately well drained, moderately permeable soils formed in alluvial material derived from limestone, sandstone, and shale. These soils are occasionally flooded for a brief period. The surface horizons of this unit typically are composed of a yellowish brown to dark grayish brown mineral horizon of loam to silt loam material. These horizons transition to a subsurface horizon (B horizon), a zone of color or structure development $12-45$ in. thick. The B horizon is underlain by a silt loam parent material. The Hamblen soils are associated with a seasonal high groundwater table of 18-36 in. BGS.

\subsubsection{Findings}

The moderately well drained Hamblen soil map unit within the LEFPC generally is composed of a loamy to silt loam surface horizon, to depths ranging from 5 to $12 \mathrm{in.} \mathrm{BGS.} \mathrm{These} \mathrm{soils} \mathrm{transition} \mathrm{to} \mathrm{a} \mathrm{silt} \mathrm{loam}$ to silty clay loam subsurface horizon to depths ranging from 28 to $58 \mathrm{in.} \mathrm{BGS.} \mathrm{This} \mathrm{horizon} \mathrm{is} \mathrm{underlain}$ by parent material consisting of silty clay loam to clay to depths of approximately 38 to greater than 96 in. BGS.

Redoximorphic features indicative of seasonally saturated conditions were observed at depths ranging from 20 to 28 in. BGS, and free water levels observed in this soil unit ranged from depths of 38 to 96 in. BGS. Based on observed soil textures, measured bulk density, and USDA saturated hydraulic conductivity classes $\left(K_{\text {sat }}\right)$, the permeability of these soils is moderate to moderately slow $(0.20$ $2.00 \mathrm{in} . / \mathrm{h})$ in the surficial alluvial material to very slow $(<0.06 \mathrm{in} . / \mathrm{h})$ in the underlying clayey sediments.

\section{SOILS BULK DENSITY}

Bulk density measurements (USDA-NRCS 2014) were conducted in each soil map unit at select locations within LEFPC. Results are summarized in the Bulk Density Summary Table in Appendix C. Overall, the measured bulk density ranged from 0.75 to $1.49 \mathrm{~g} / \mathrm{cm}^{3}$ in the Chenneby soil series and from 0.91 to 1.39 $\mathrm{g} / \mathrm{cm}^{3}$ in the Hamblen soil series, indicating some hydraulically restrictive layers within the underlying parent materials of both soil series.

\section{CONCLUSIONS}

Soils in the evaluated LEFPC were mapped as somewhat poorly to moderately well-drained with moderate to slowly permeable subsoil/substratum. These soils occupy lower landscape positions such as floodplains and depressions where slopes are slight to nearly level (from 0 to $3 \%$ ). The Chenneby soils are associated with limiting zones ranging from approximately 8 to $18 \mathrm{in}$. BGS and slow permeability in the geologic parent materials. The Hamblen soils have limiting zones ranging from approximately 20 to 28 in. BGS and moderate to slow permeability in the clayey parent materials. It should be noted that both series include minor components $(<10 \%)$ of Ennis series (Fluventic Dystrudepts), urban soils, and rock outcrops. Some areas within these soil map units may be classified as wetlands, given the presence of appropriate wetland vegetation and hydrology. 
This investigation has provided an improved knowledge of soil types and physical properties in LEFPC that could be useful to the development and application of remedial technologies such as bank stabilization techniques, chemical treatment, or use of sorbents to mitigate mercury contamination in bank soils. For example, soil layers with high(er) $\mathrm{Hg}$ content and high(er) permeability $\left(K_{\text {sat }}\right)$ can more easily conduct water and release $\mathrm{Hg}$ to EFPC, and these soils would represent higher priority zones for targeted action. Combining results of the present study of soil properties with those of previous and ongoing studies of $\mathrm{Hg}$ content and release rate will help to prioritize remedial action zones.

\section{REFERENCES}

Brooks, Scott C., and George R. Southworth. 2011. "History of Mercury Use and Environmental Contamination at the Oak Ridge Y-12 Plant." Environmental Pollution 159 (1):219-228. doi: 10.1016/j.envpol.2010.09.009.

Carmichael, John K. 1989. An Investigation of Shallow Groundwater Quality Near East Fork Poplar Creek, Oak Ridge, Tennessee. US Geological Survey, Nashville, Tenn.

Hardeman, W. D., R. A. Miller, and G. D. Swingle. 1966. Geologic Map of Tennessee. Tennessee Division of Geology.

Hatcher, R. D. 1987. "Tectonics of the Southern and Central Appalachian Internides." Annual Review of Earth and Planetary Sciences 15:337-362. doi: 10.1146/annurev.ea.15.050187.002005.

NOAA. 2015. NOAA Online Weather Data for Oak Ridge area, http://nowdata.rcc-acis.org/mrx/. Oak Ridge, Tenn.

Tennessee Valley Authority. 1985a. Instream Contaminant Study, Task 1: Water Sampling and Analysis Report to US Department of Energy. Office of Natural Resources and Economic Development, Tennessee Valley Authority, Knoxville, Tenn.

Tennessee Valley Authority. 1985b. Instream Contaminant Study, Task 3: Sediment Transport Report to US Department of Energy. Office of Natural Resources and Economic Development, Tennessee Valley Authority, Knoxville, Tenn. doi: 10.2172/1082023.

USDA-NRCS. 2014. Soil Bulk Density. US Department of Agriculture, Natural Resources Conservation Service, Washington, DC. Available from http://www.nrcs.usda.gov/Internet/FSE DOCUMENTS/nrcs142p2 053260.pdf.

USDA. 2015. Soil Survey of Anderson County, Tenn. (http://websoilsurvey.sc.egov.usda.gov/App/WebSoilSurvey.aspx). Anderson County, Tenn.

Vepraska, M. J. 1999. Redoximorphic Features for Identifying Aquic Conditions. North Carolina Agricultural Research Service Technical Bulletin No. 301, North Carolina State University, Raleigh. 

APPENDIX A. SOIL MAPS SHOWING THE DISTRIBUTION OF SOIL MAP UNITS ALONG LOWER EAST FORK POPLAR CREEK 



\section{APPENDIX A. SOIL MAPS SHOWING THE DISTRIBUTION OF SOIL MAP UNITS ALONG}

LOWER EAST FORK POPLAR CREEK

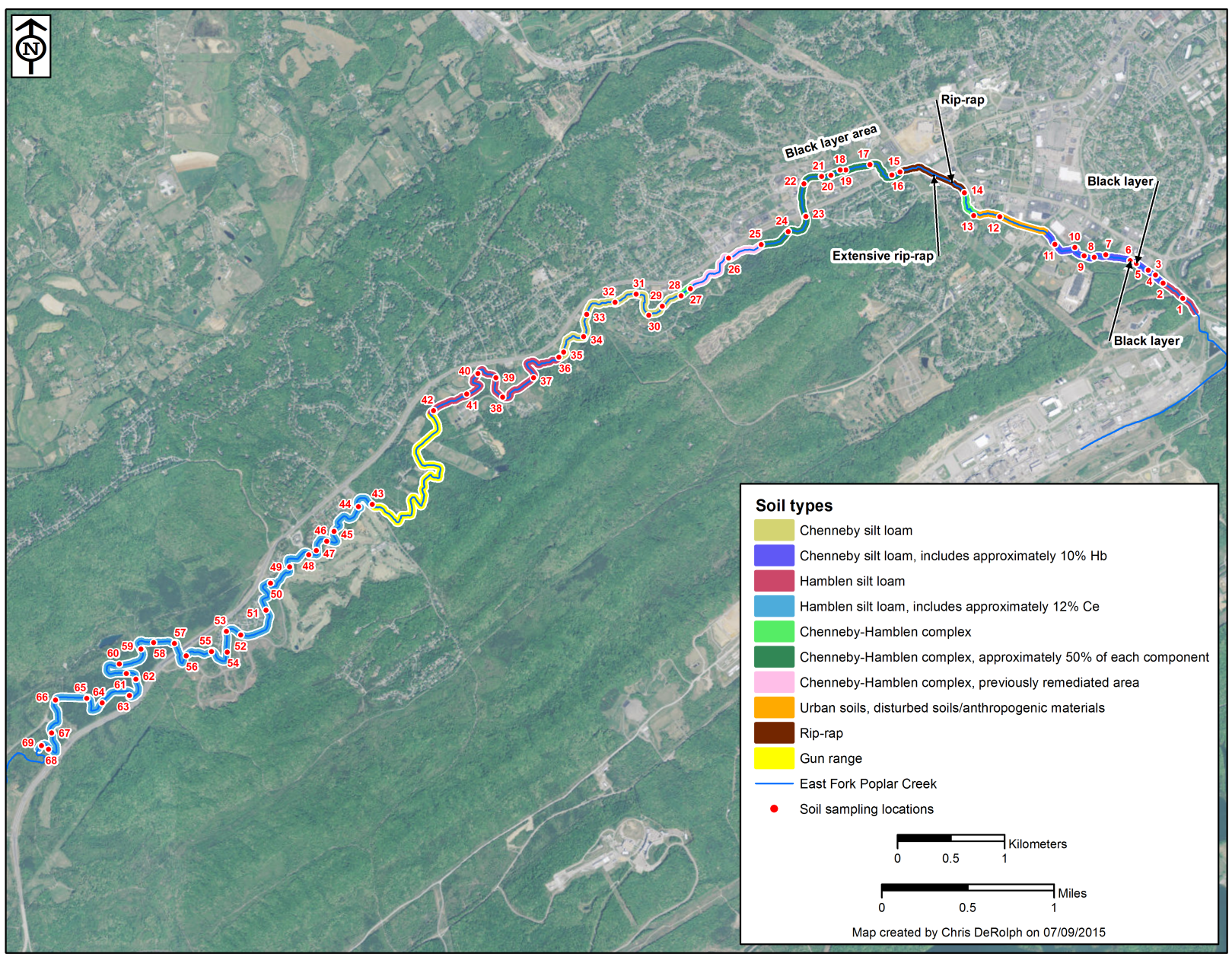

Fig. A.1. Map of soil types along lower East Fork Poplar Creek. 


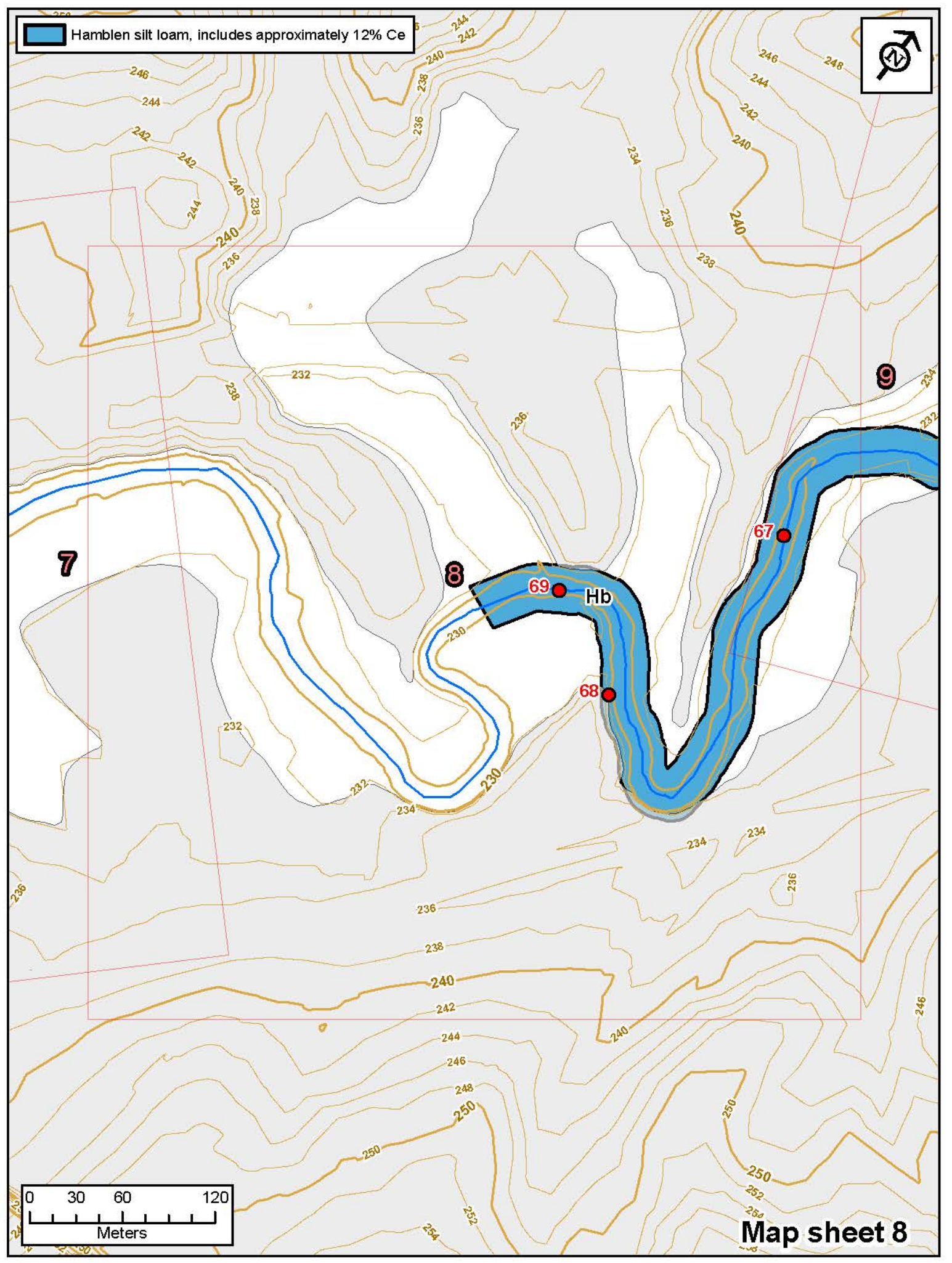

Fig. A.2. Map of soil types at bank locations 67-69 along lower East Fork Poplar Creek. 


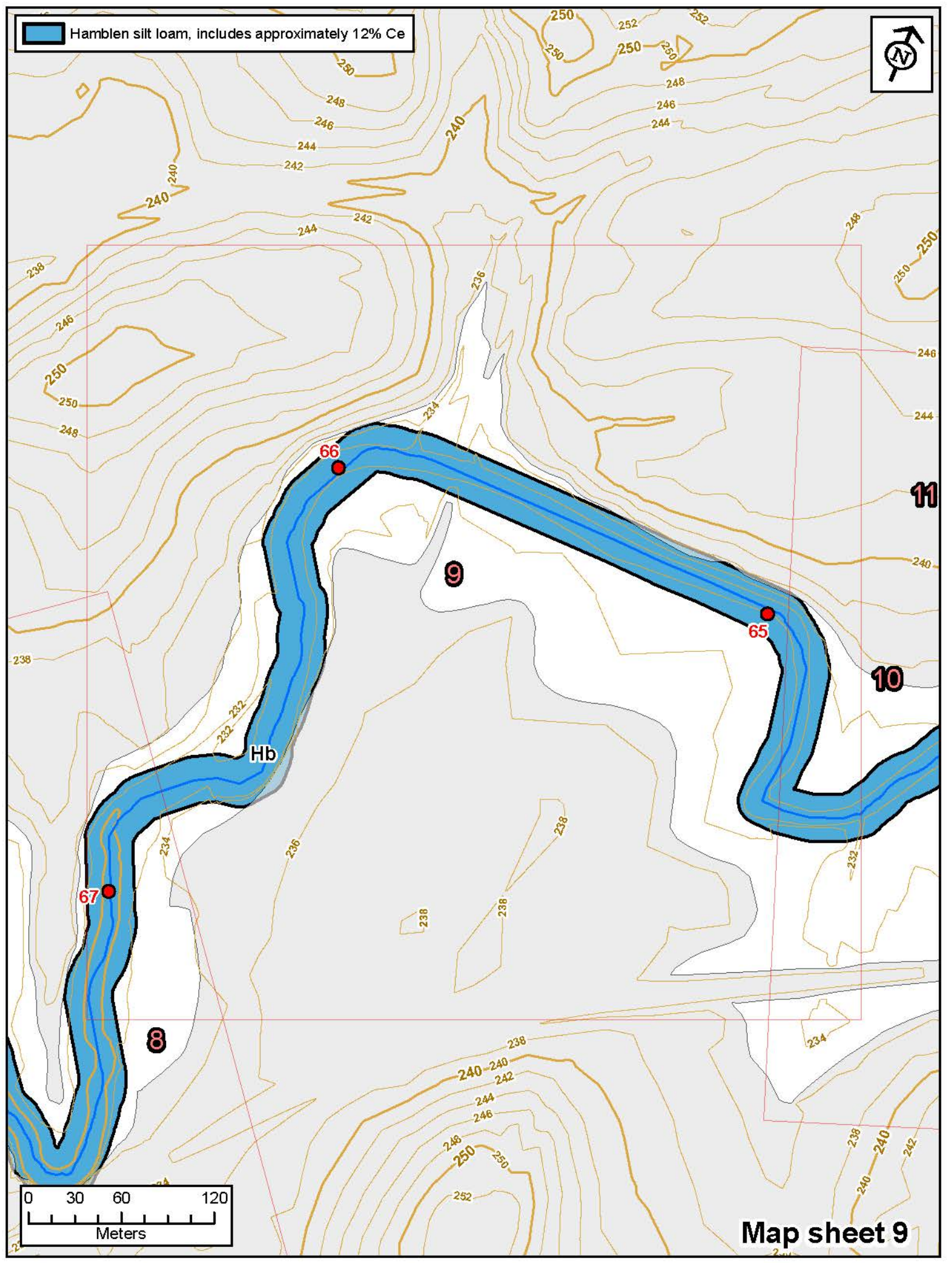

Fig. A.3. Map of soil types at bank locations 65-67 along lower East Fork Poplar Creek. 


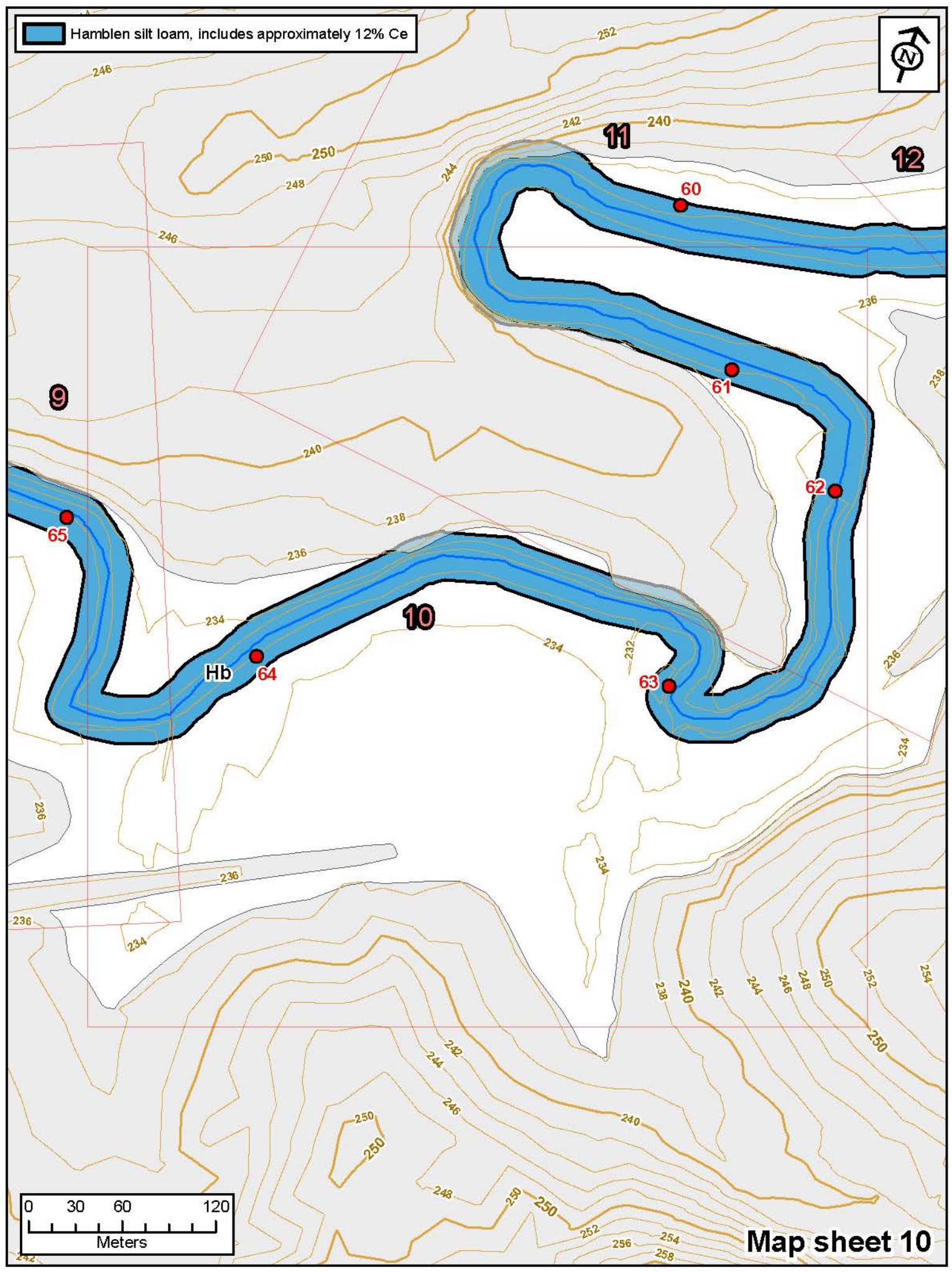

Fig. A.4. Map of soil types at bank locations 60-65 along lower East Fork Poplar Creek. 


$$
\text { if }
$$




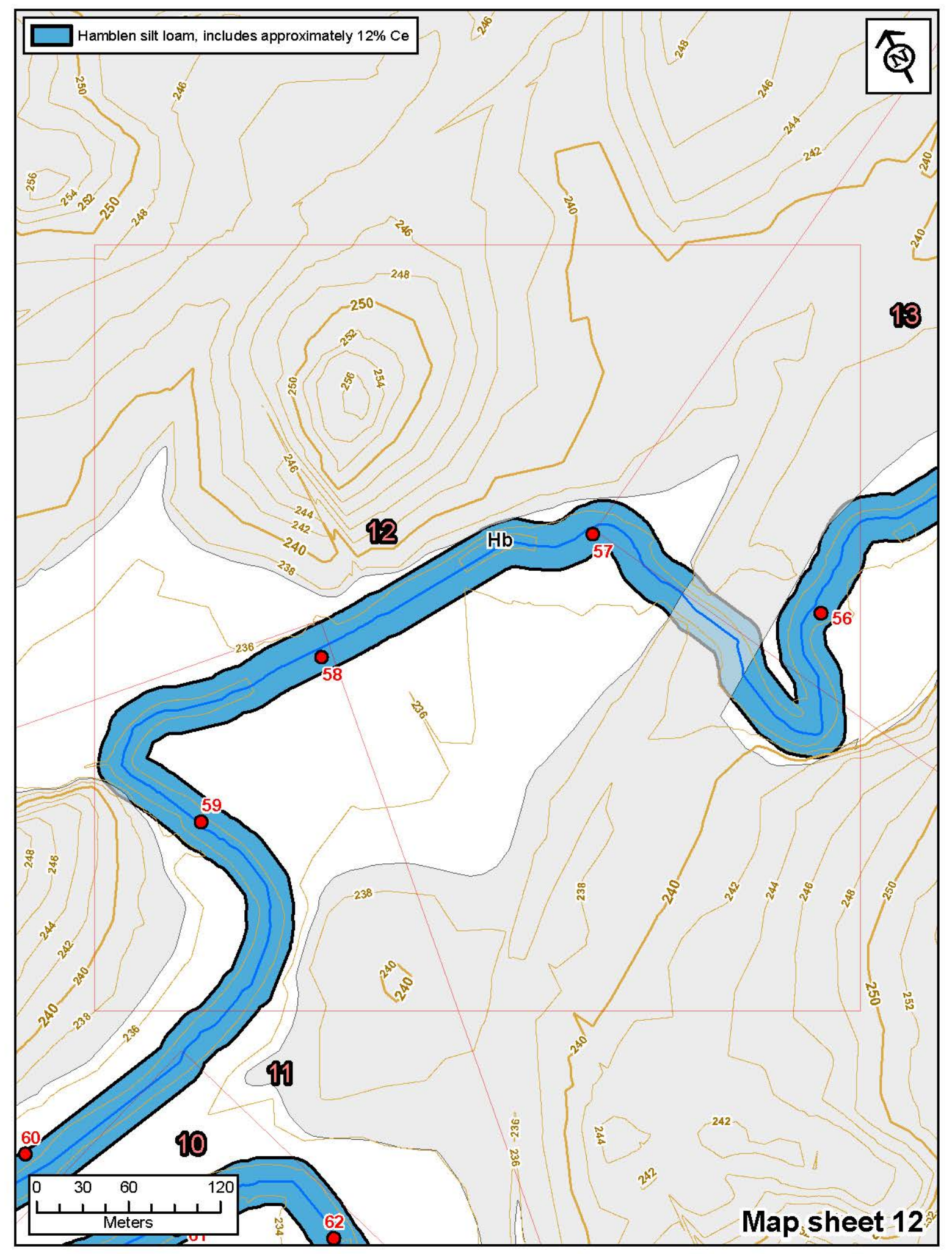

Fig. A.6. Map of soil types at bank locations 56-62 along lower East Fork Poplar Creek. 


$$
\bar{L}_{2}
$$




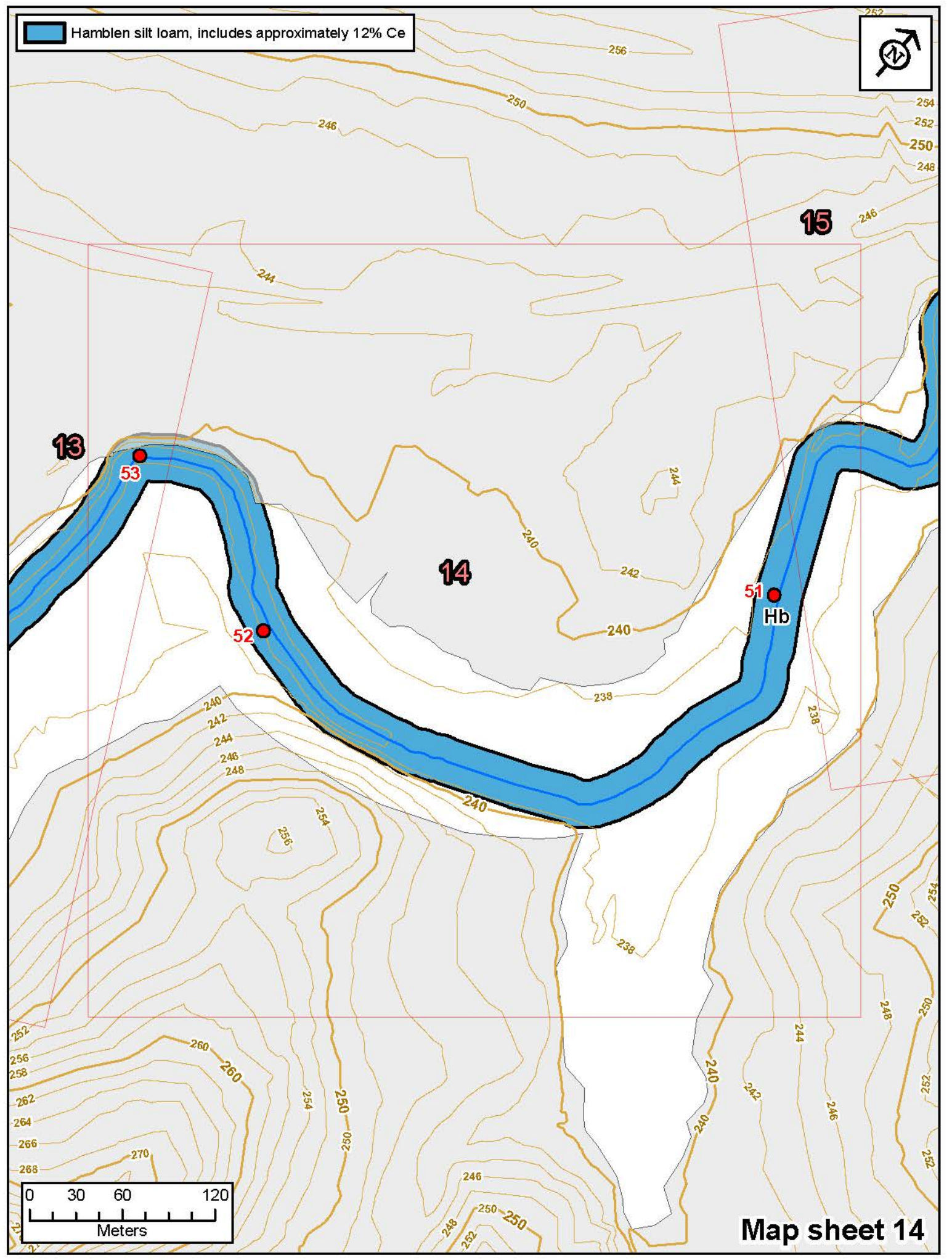

Fig. A.8. Map of soil types at bank locations 51-53 along lower East Fork Poplar Creek. 


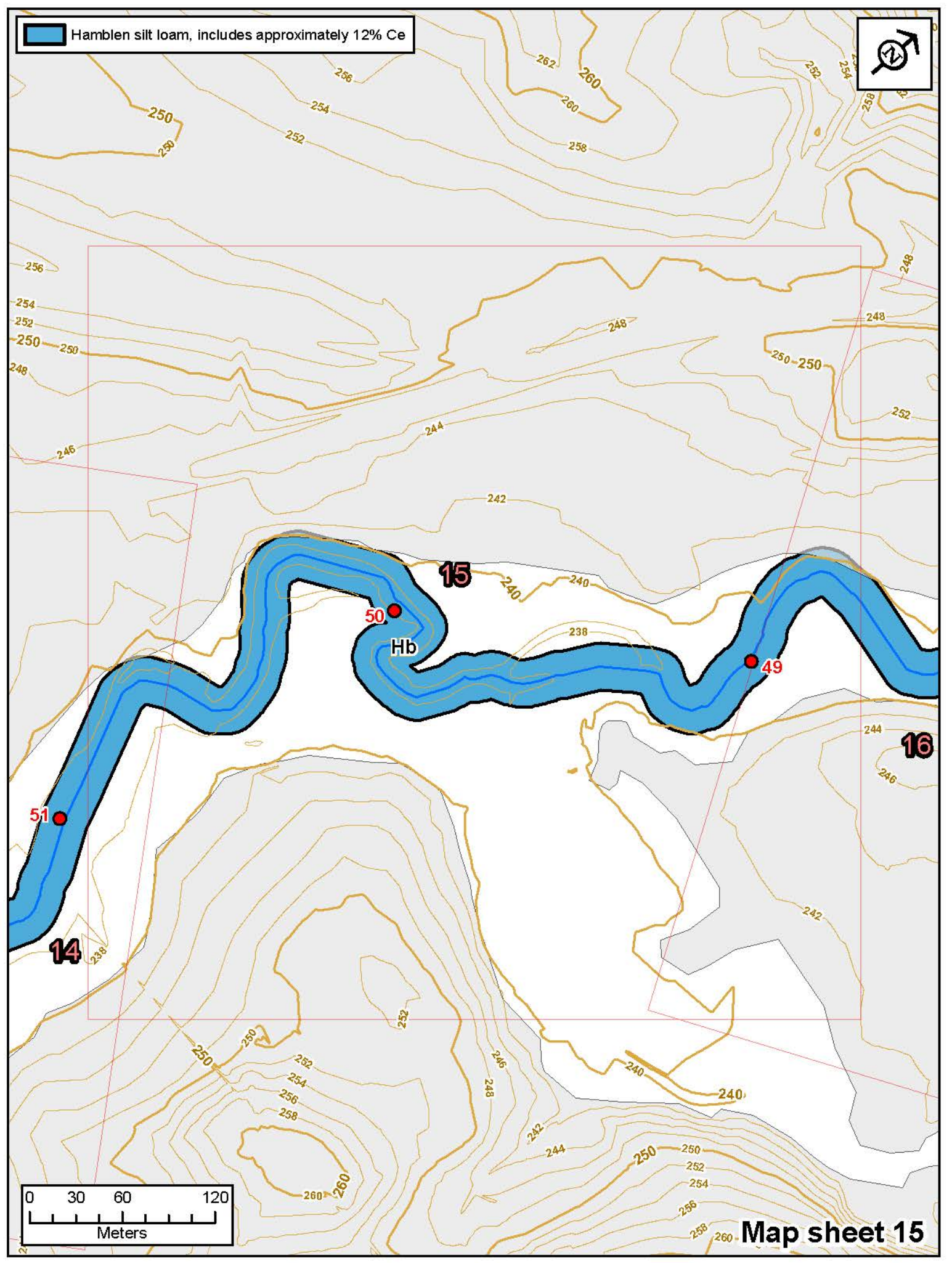

Fig. A.9. Map of soil types at bank locations 49-51 along lower East Fork Poplar Creek. 


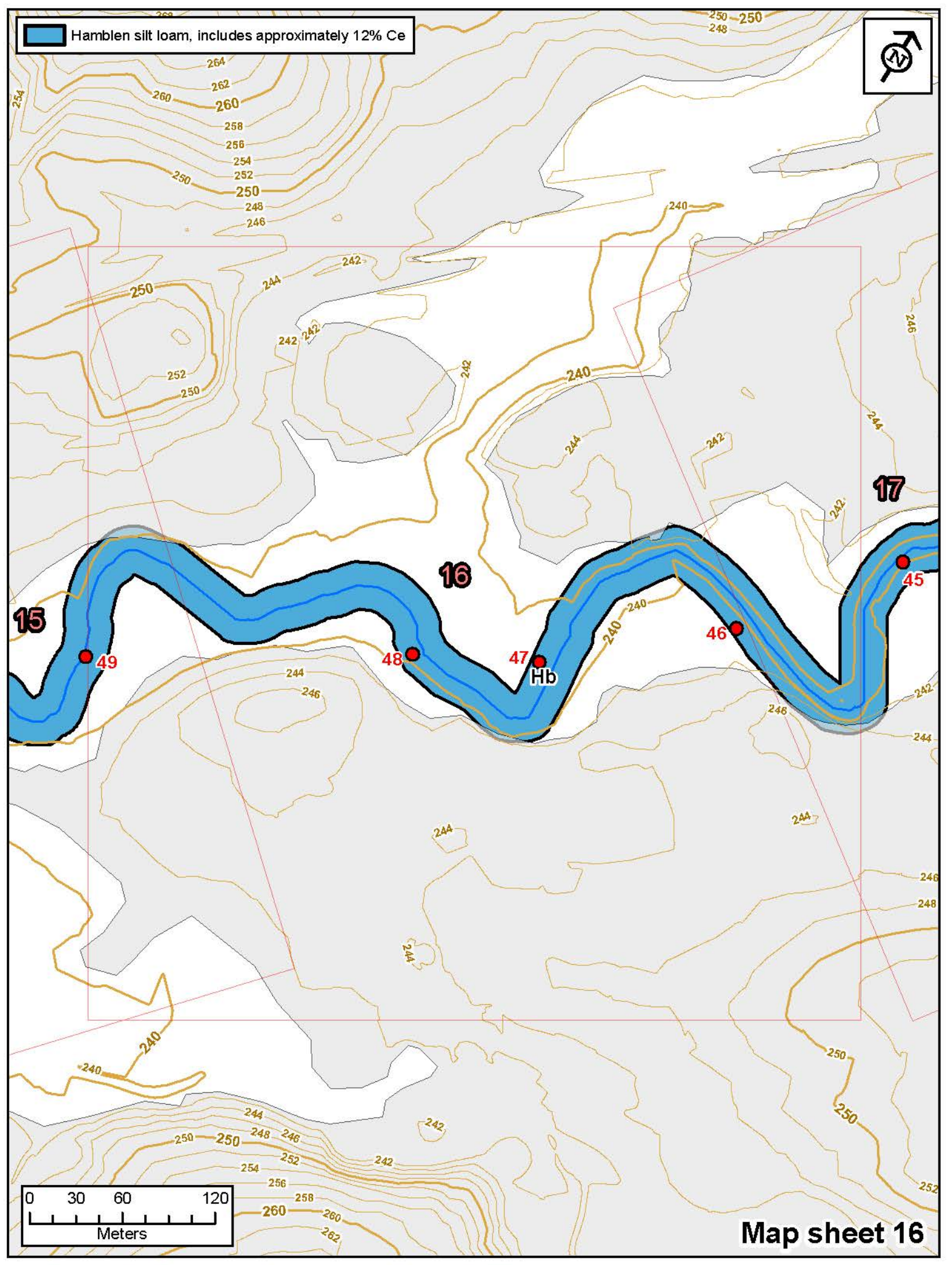

Fig. A.10. Map of soil types at bank locations 45-49 along lower East Fork Poplar Creek. 


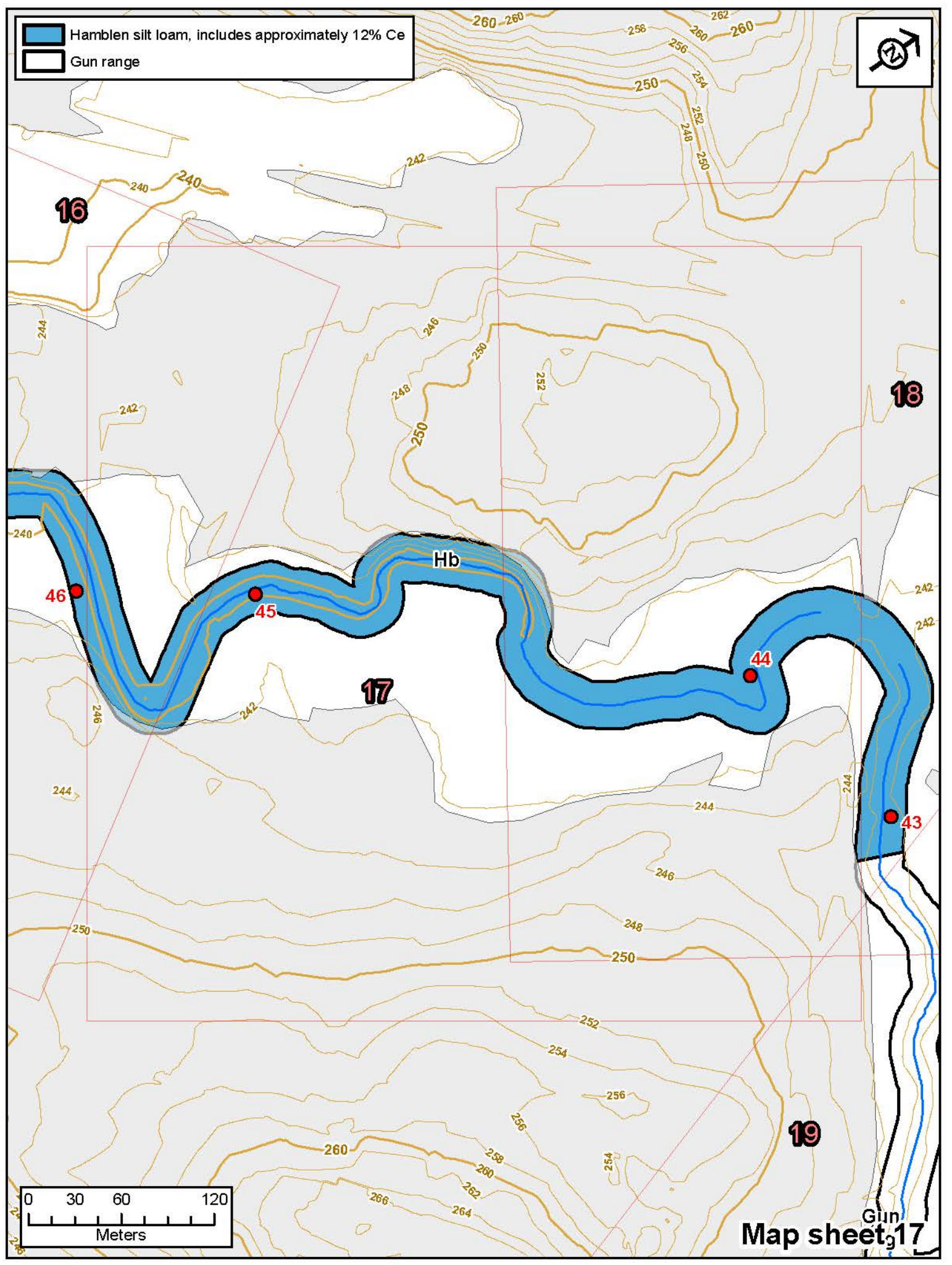

Fig. A.11. Map of soil types at bank locations 43-46 along lower East Fork Poplar Creek. 


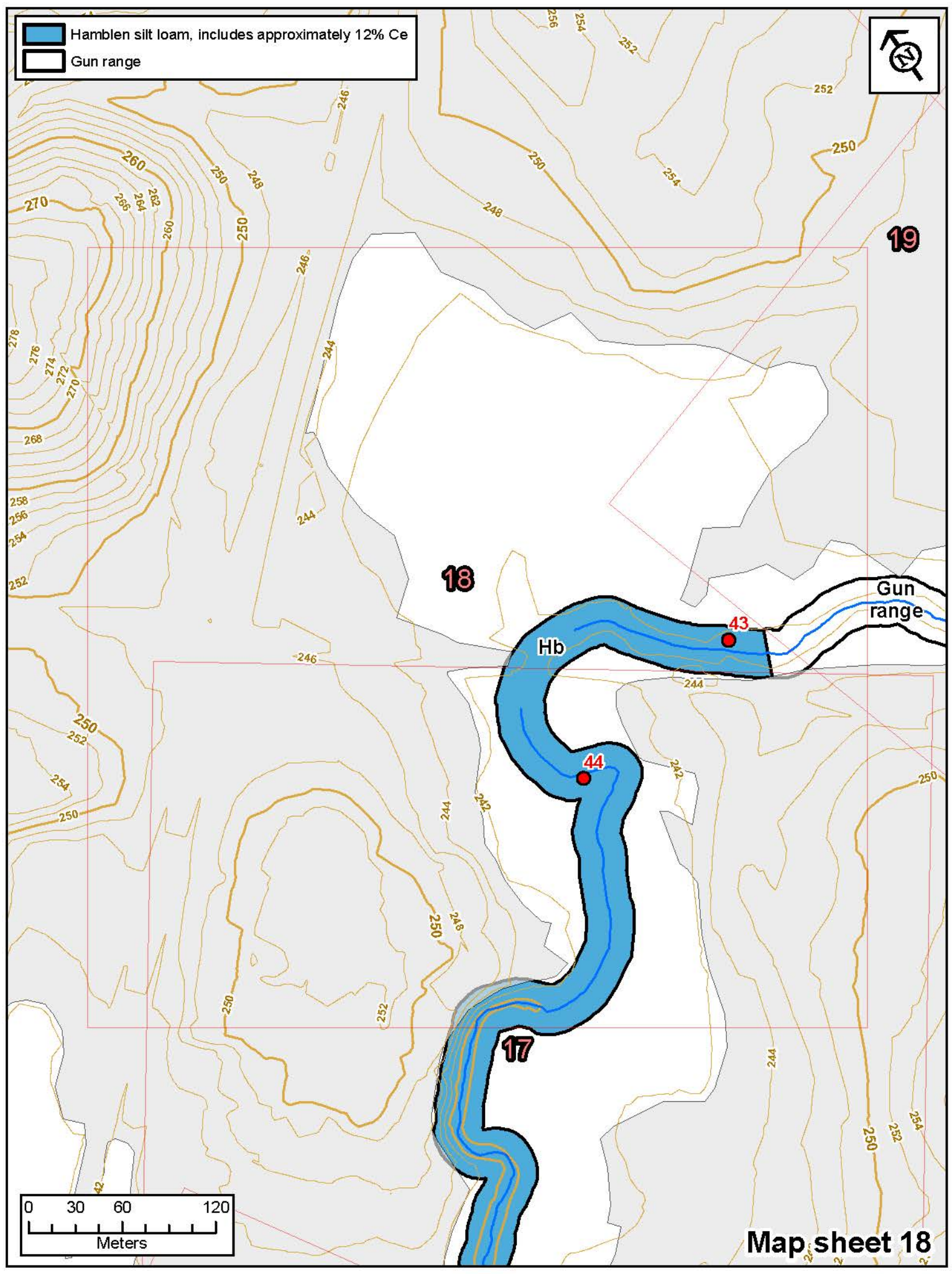

Fig. A.12. Map of soil types at bank locations 43-44 along lower East Fork Poplar Creek. 


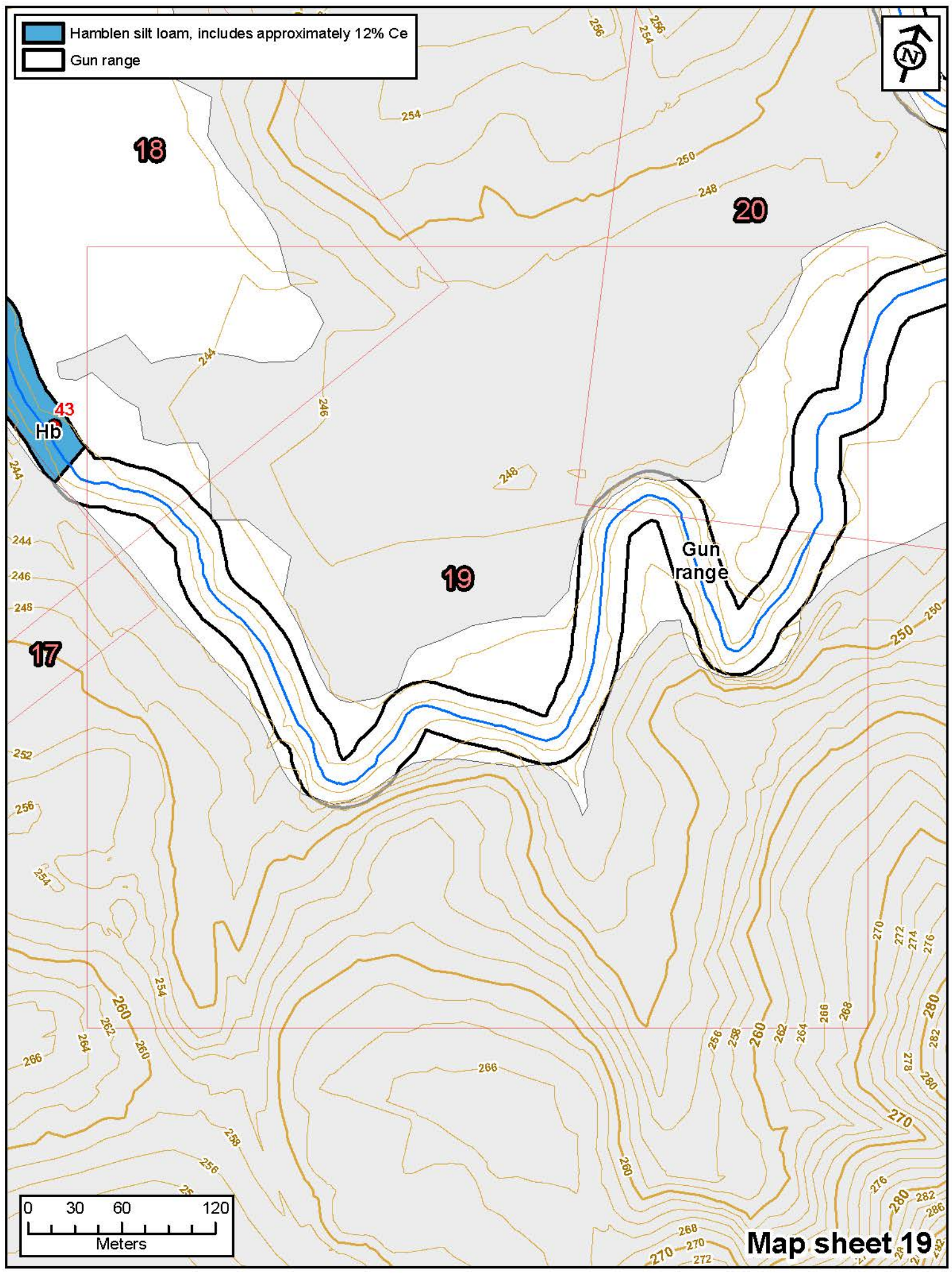

Fig. A.13. Map of soil types at bank location 43 and the gun range along lower East Fork Poplar Creek. 


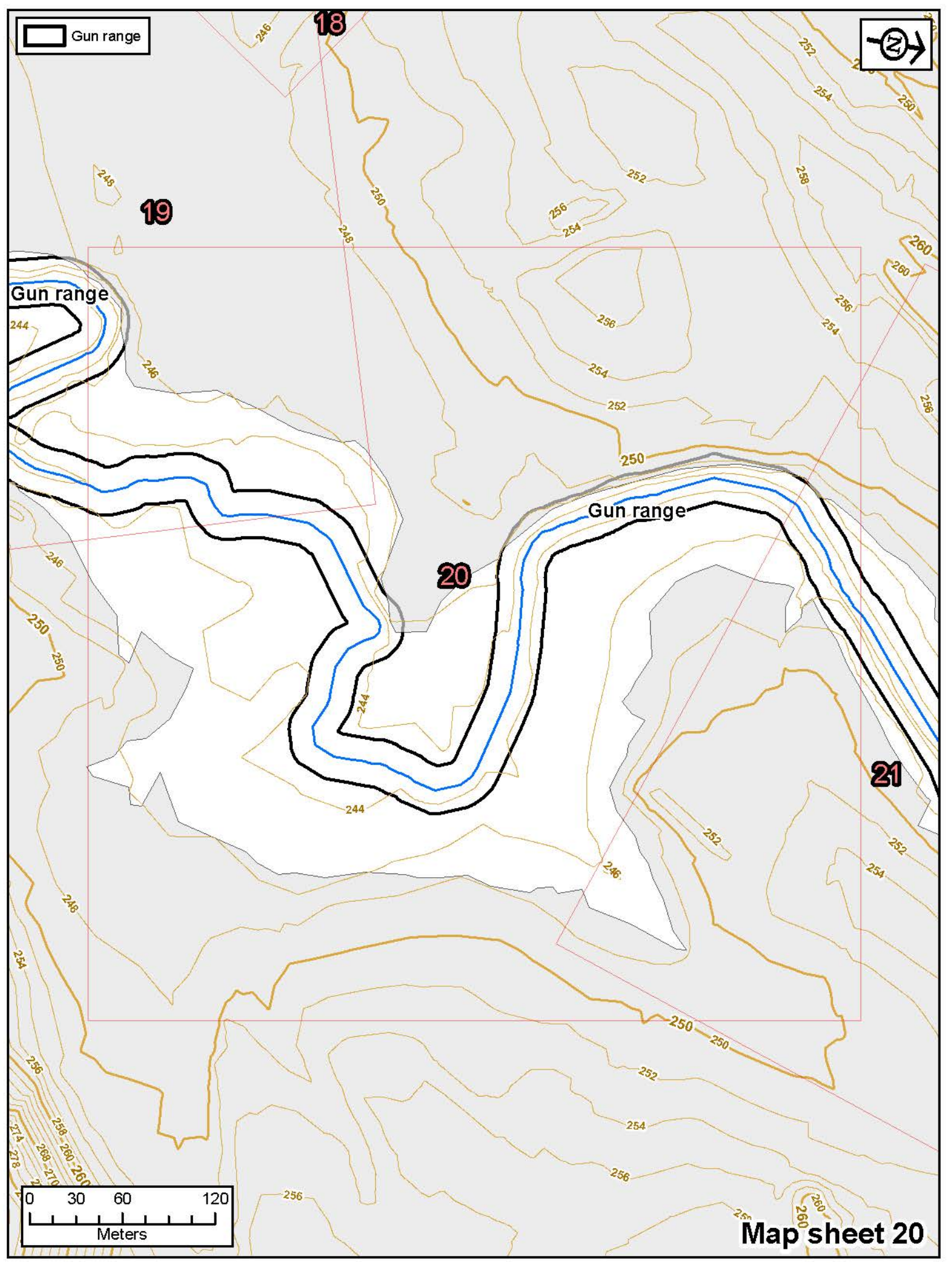

Fig. A.14. Map of soil types at the gun range along lower East Fork Poplar Creek. 


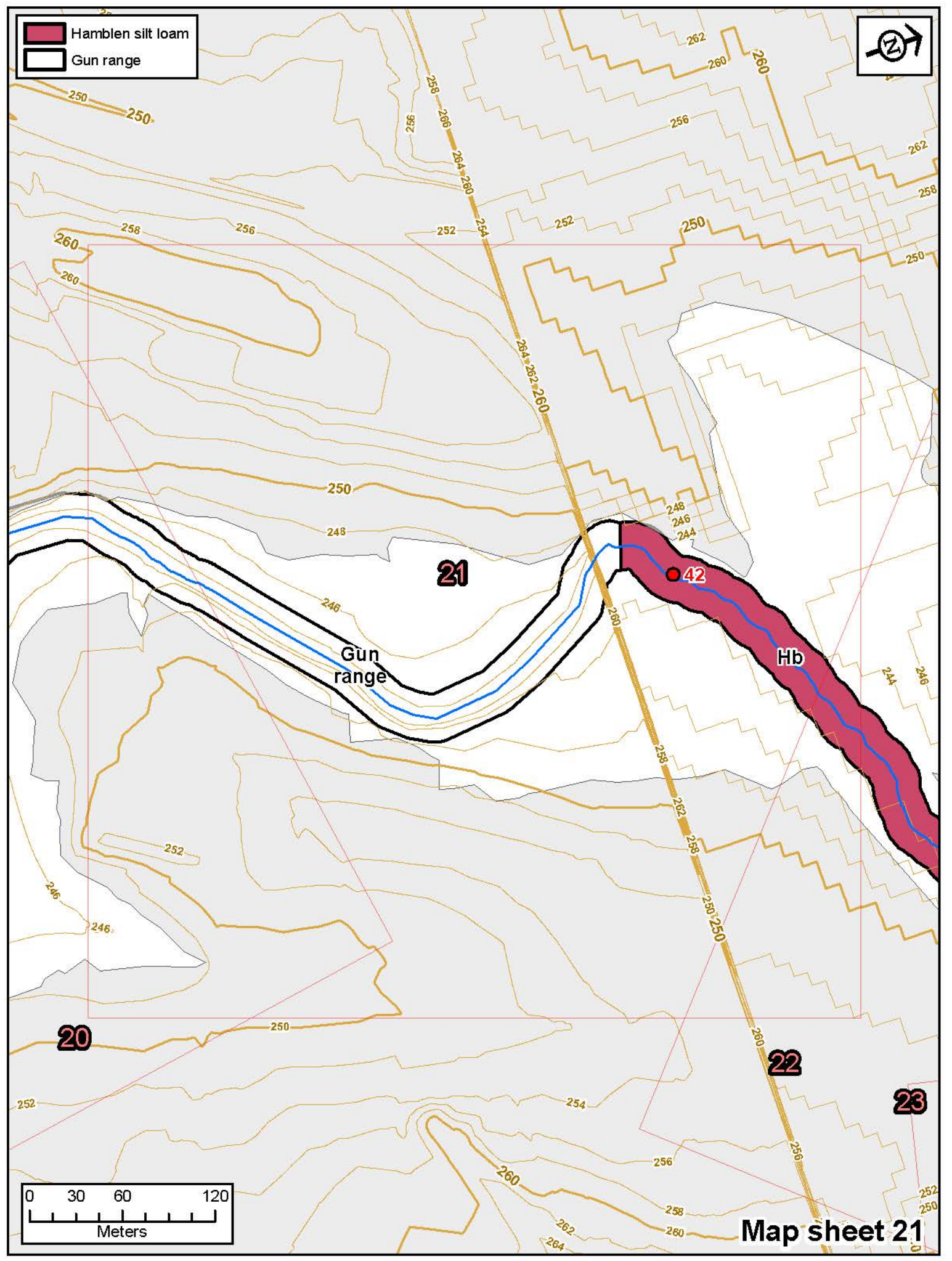

Fig. A.15. Map of soil types at bank location 42 and the gun range along lower East Fork Poplar Creek. 


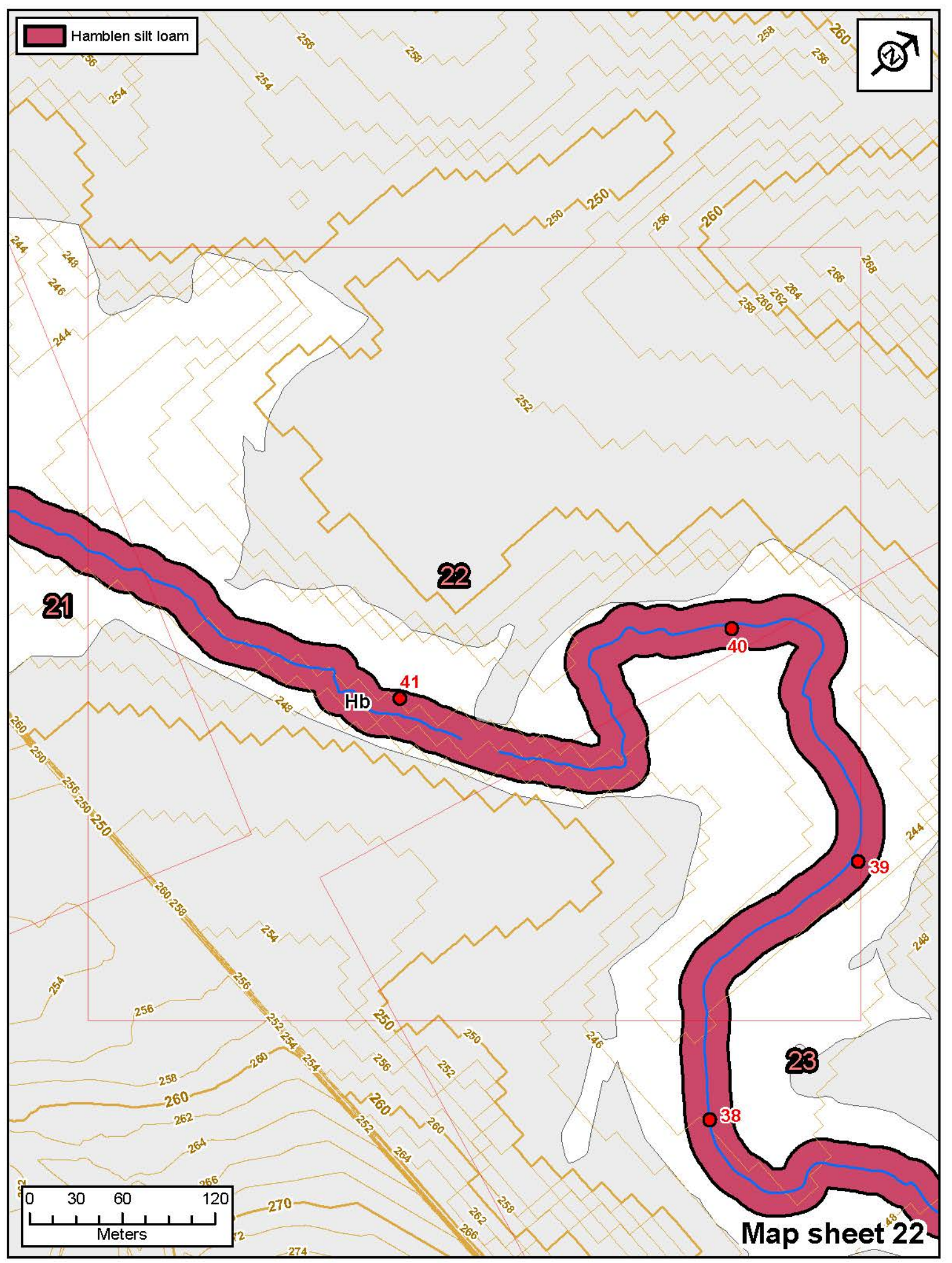

Fig. A.16. Map of soil types at bank locations 38-41 along lower East Fork Poplar Creek. 


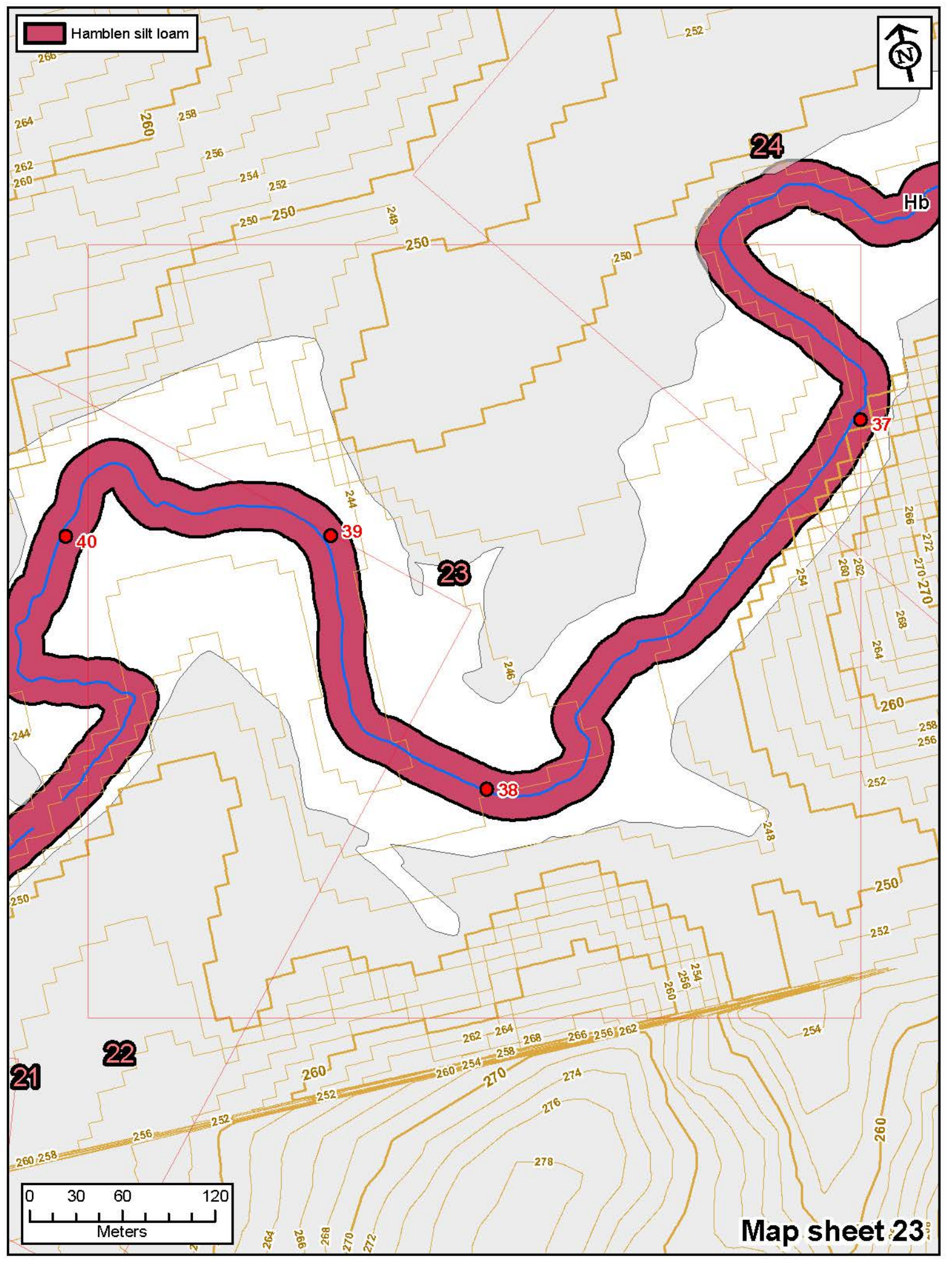

Fig. A.17. Map of soil types at bank locations 37-40 along lower East Fork Poplar Creek. 


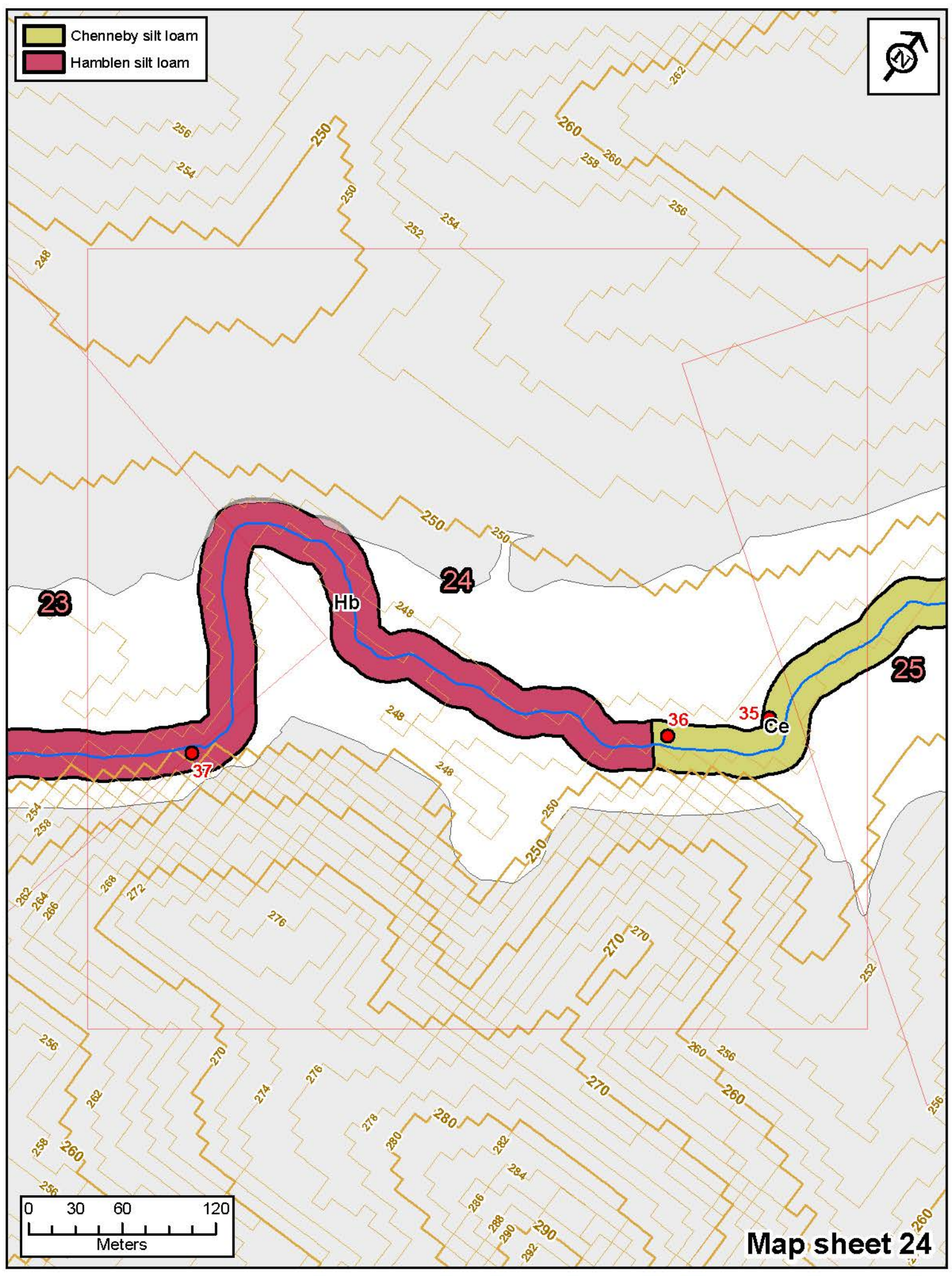

Fig. A.18. Map of soil types at bank locations 35-37 along lower East Fork Poplar Creek. 


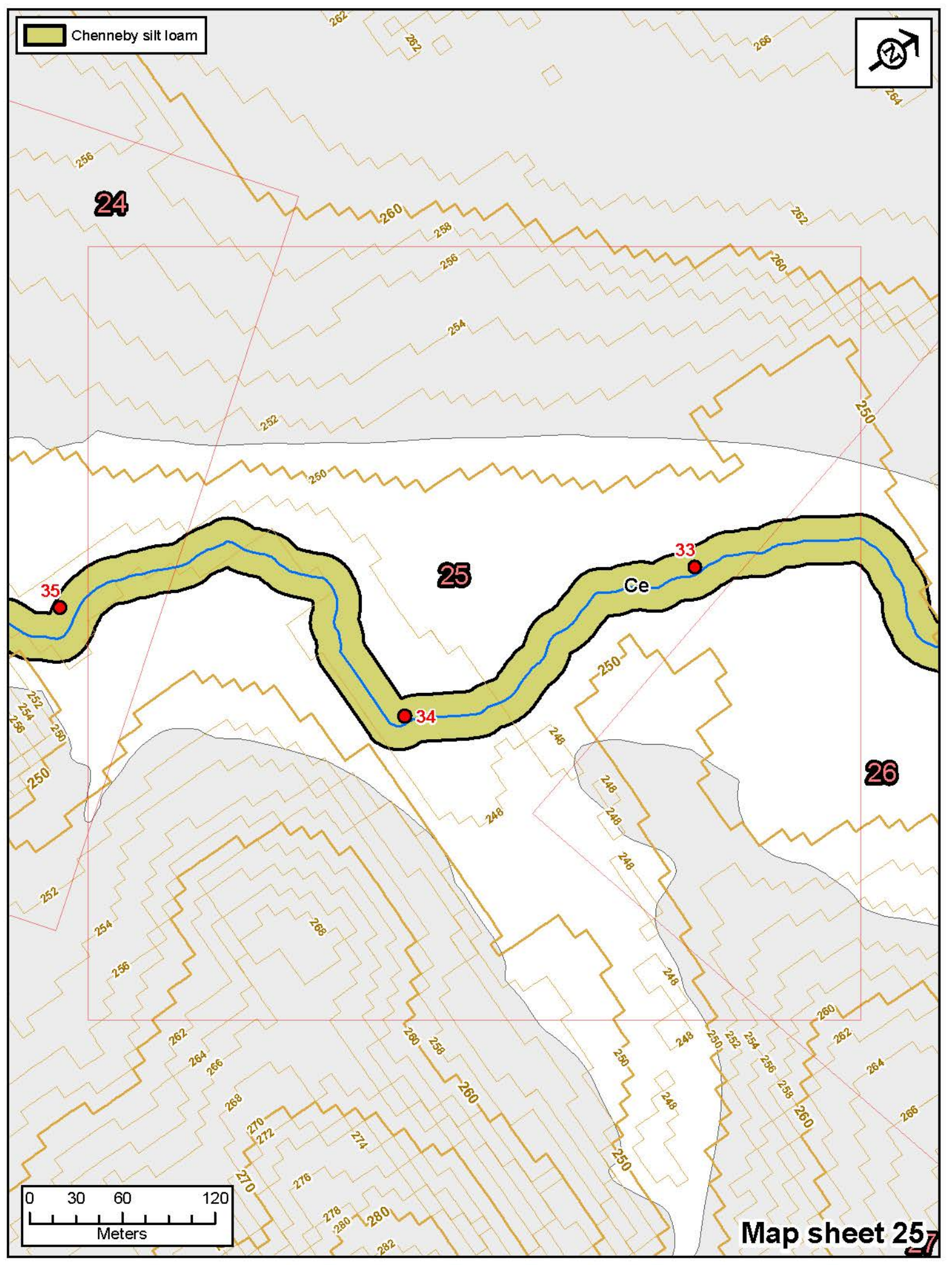

Fig. A.19. Map of soil types at bank locations 33-35 along lower East Fork Poplar Creek. 


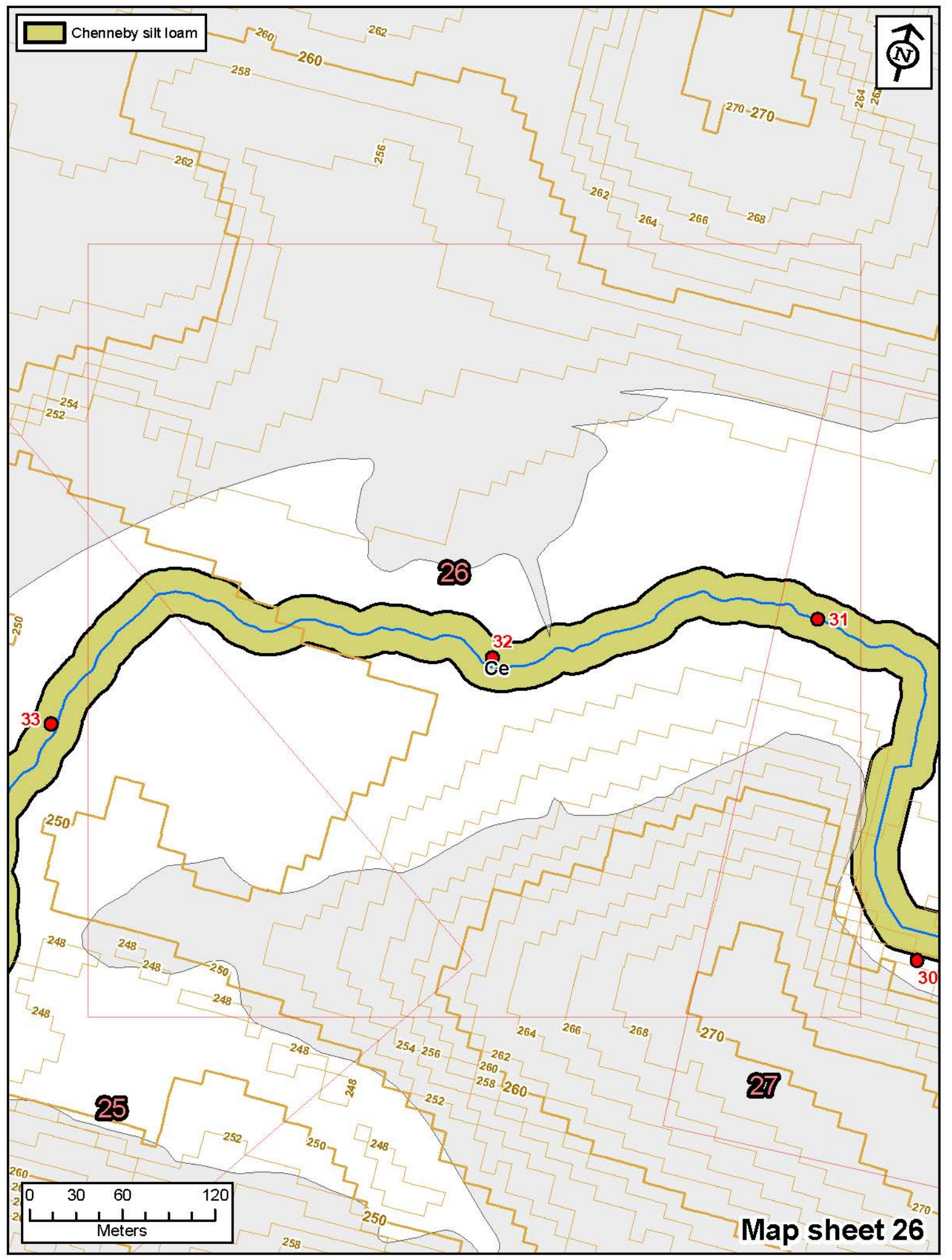

Fig. A.20. Map of soil types at bank locations 30-33 along lower East Fork Poplar Creek. 


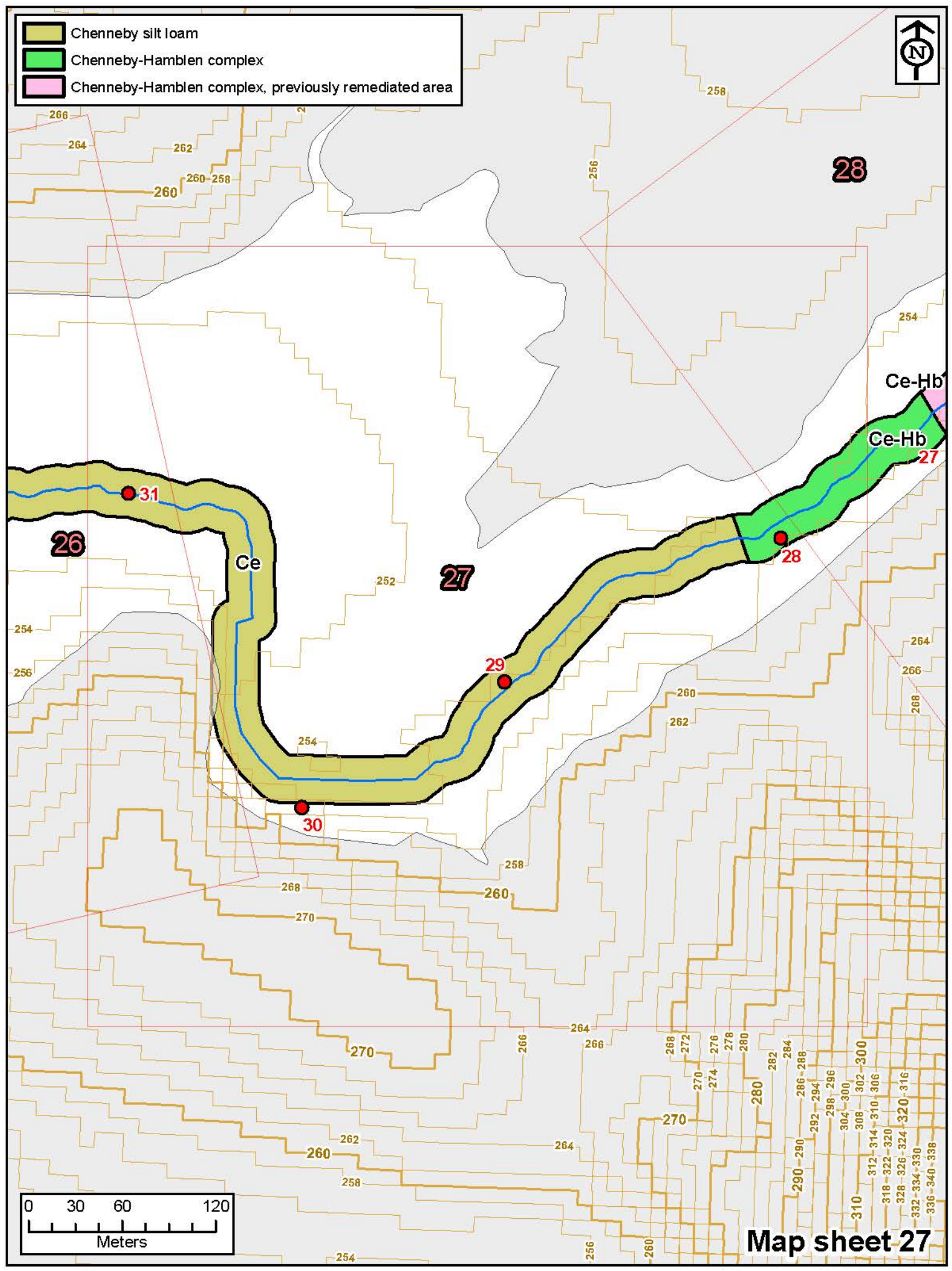

Fig. A.21. Map of soil types at bank locations 27-31 along lower East Fork Poplar Creek. 


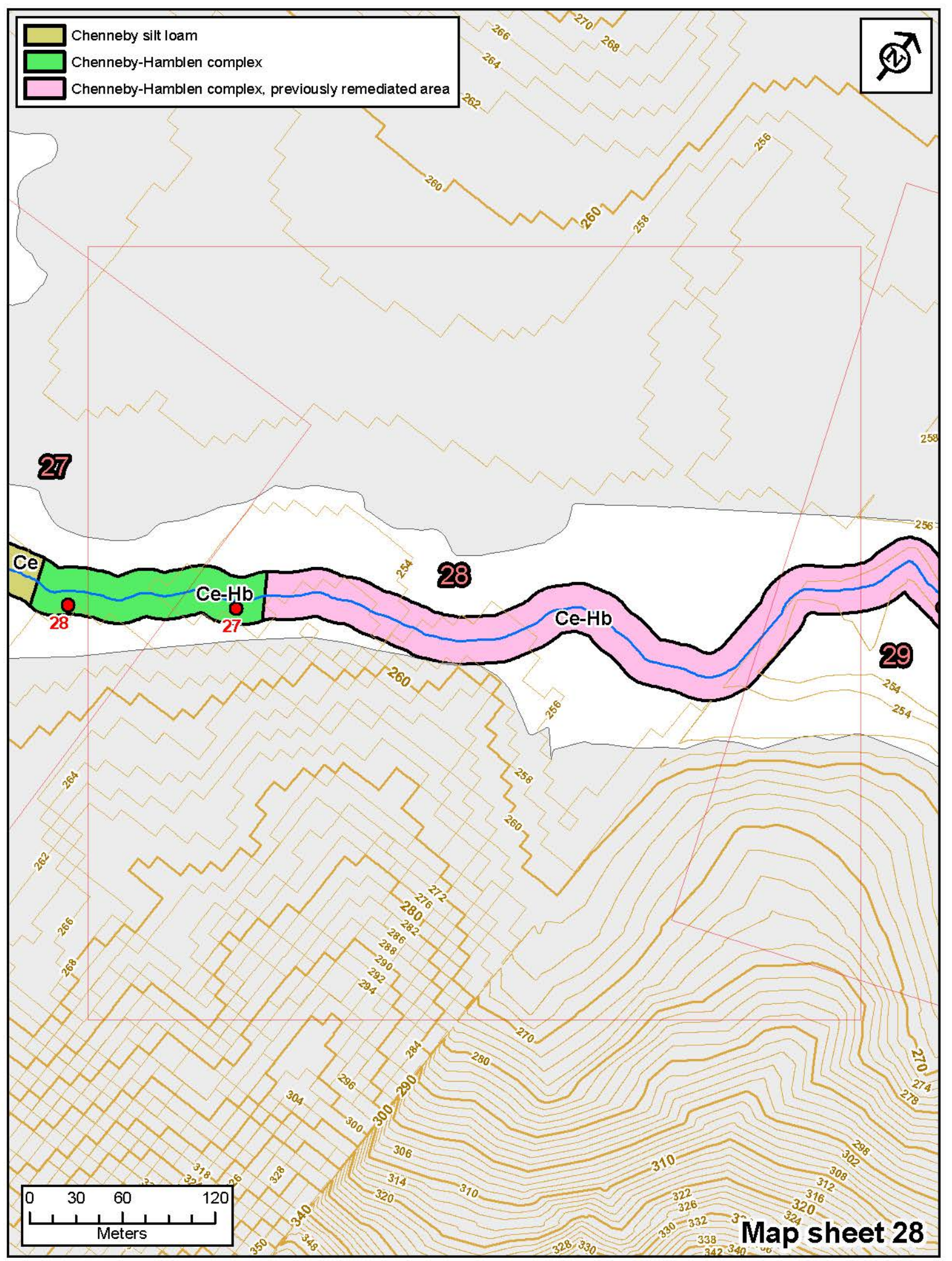

Fig. A.22. Map of soil types at bank locations 27-28 along lower East Fork Poplar Creek. 


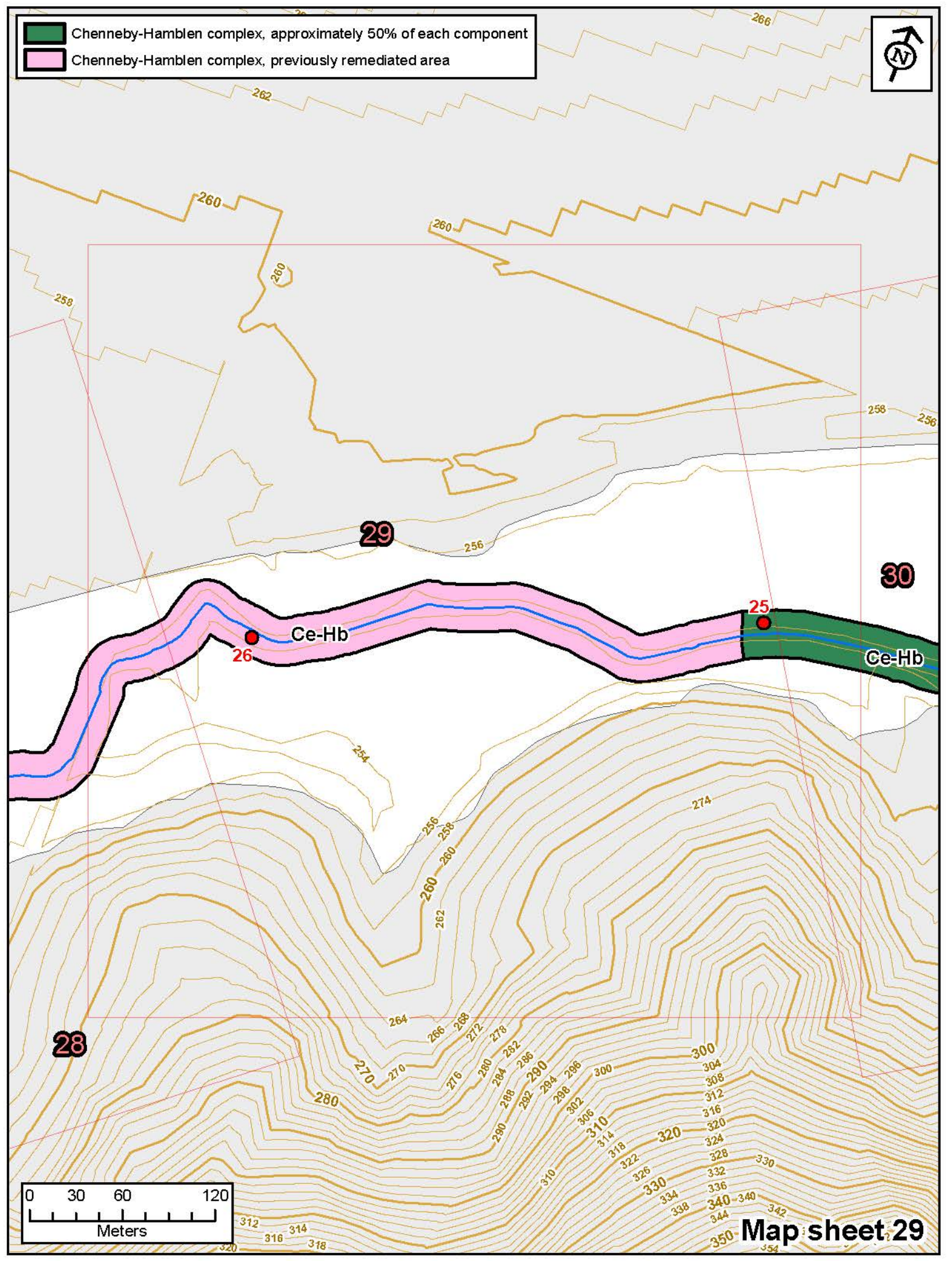

Fig. A.23. Map of soil types at bank locations 25-26 along lower East Fork Poplar Creek. 


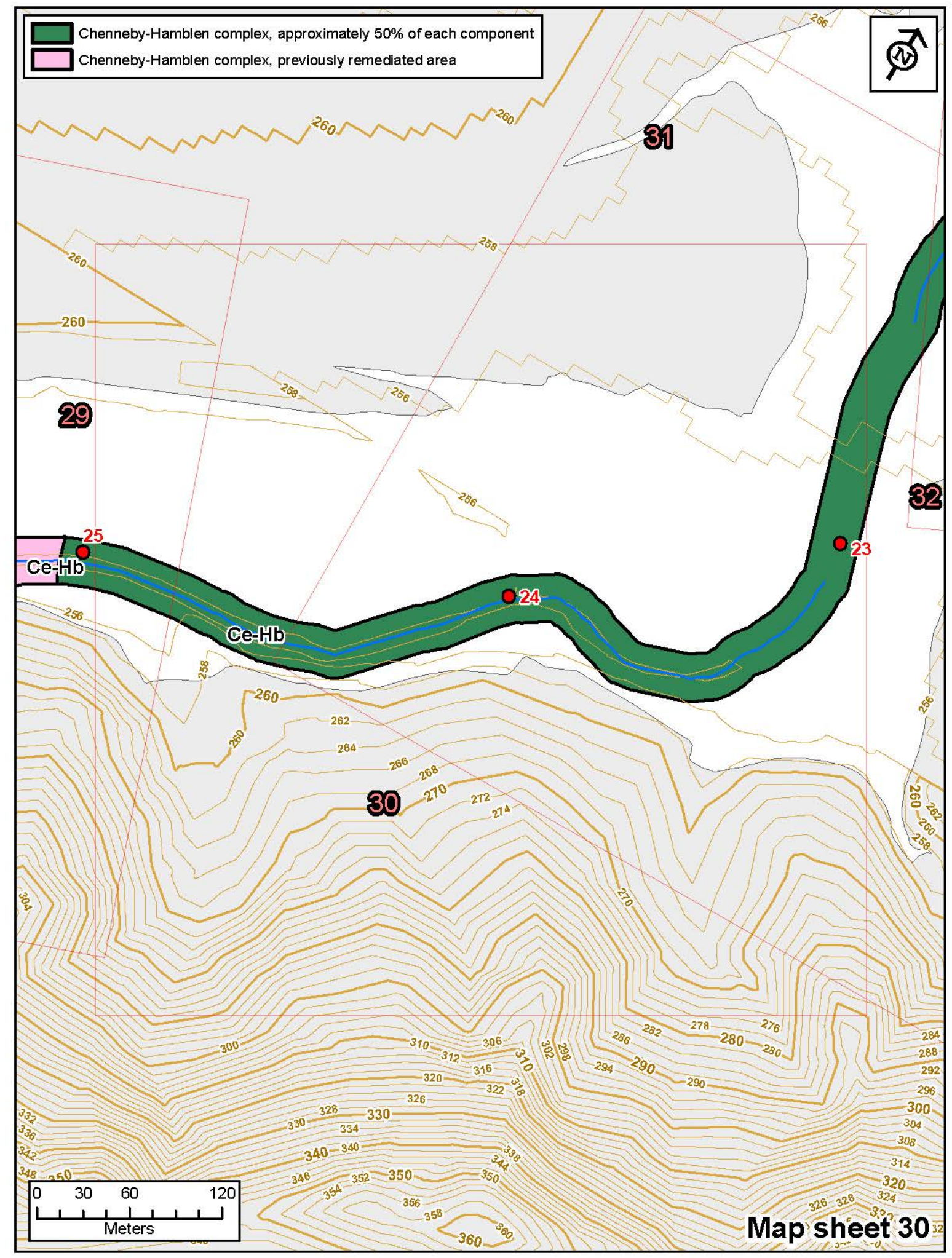

Fig. A.24. Map of soil types at bank locations 23-25 along lower East Fork Poplar Creek. 


$$
E
$$




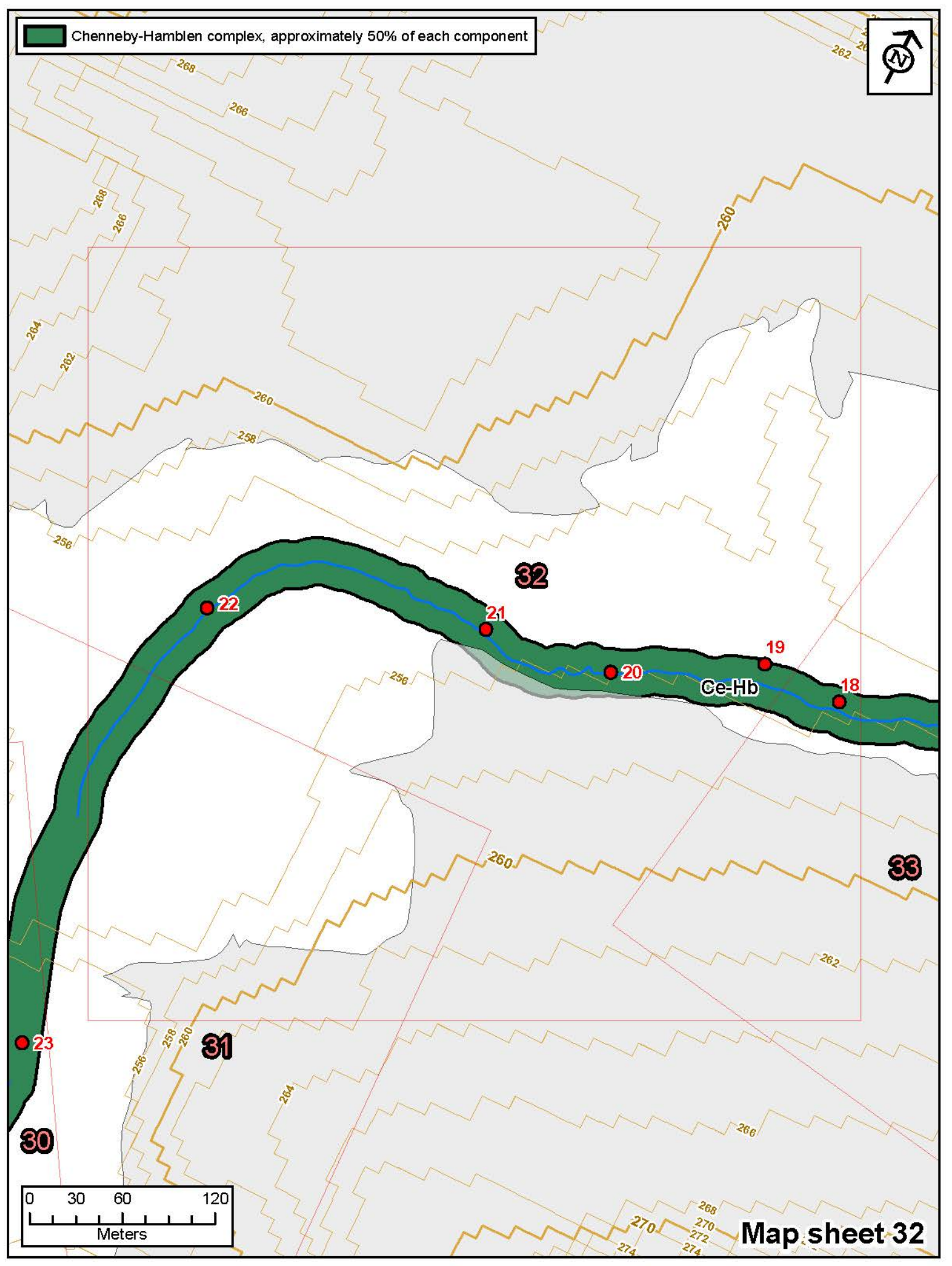

Fig. A.26. Map of soil types at bank locations 18-23 along lower East Fork Poplar Creek. 


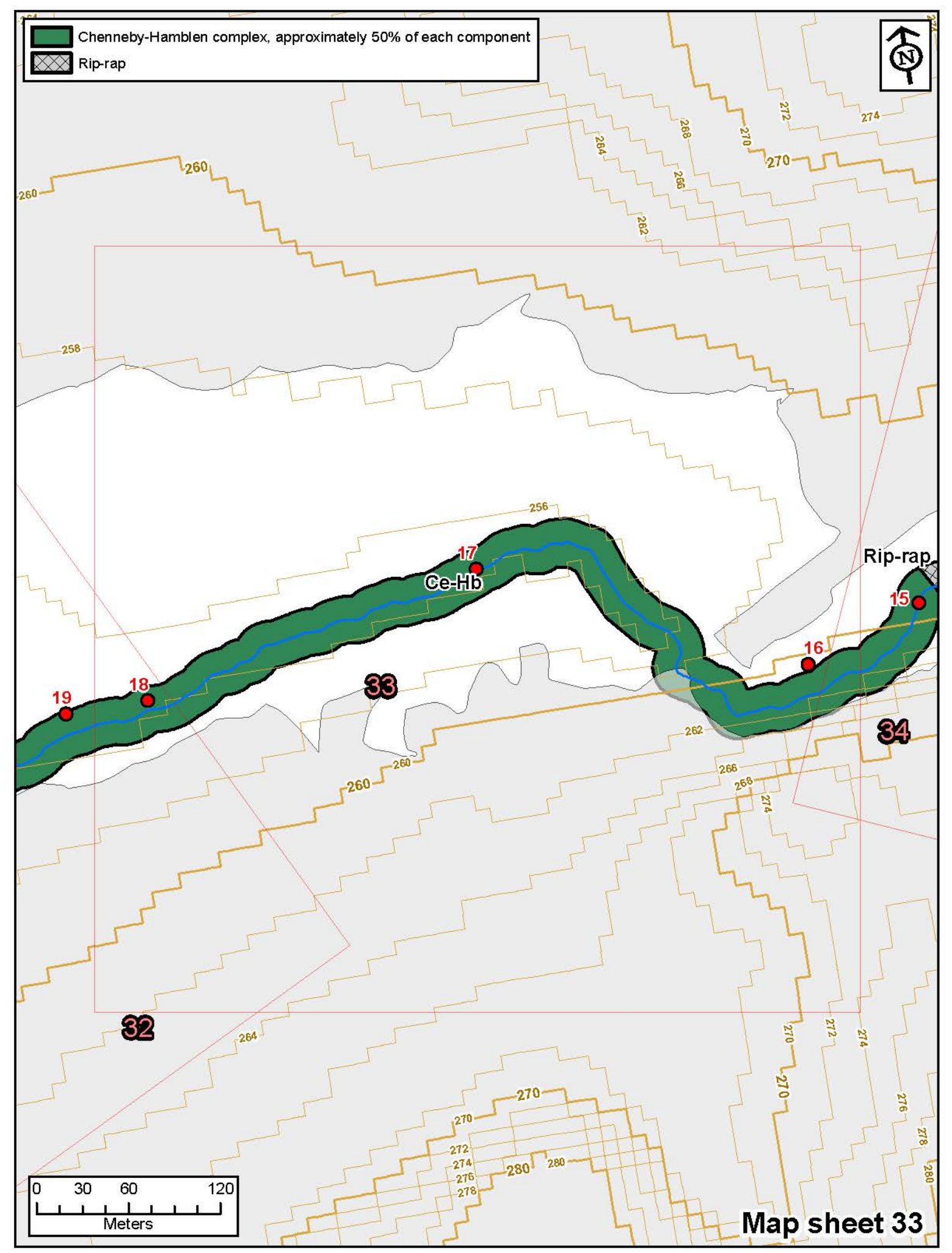

Fig. A.27. Map of soil types at bank locations 15-19 along lower East Fork Poplar Creek. 


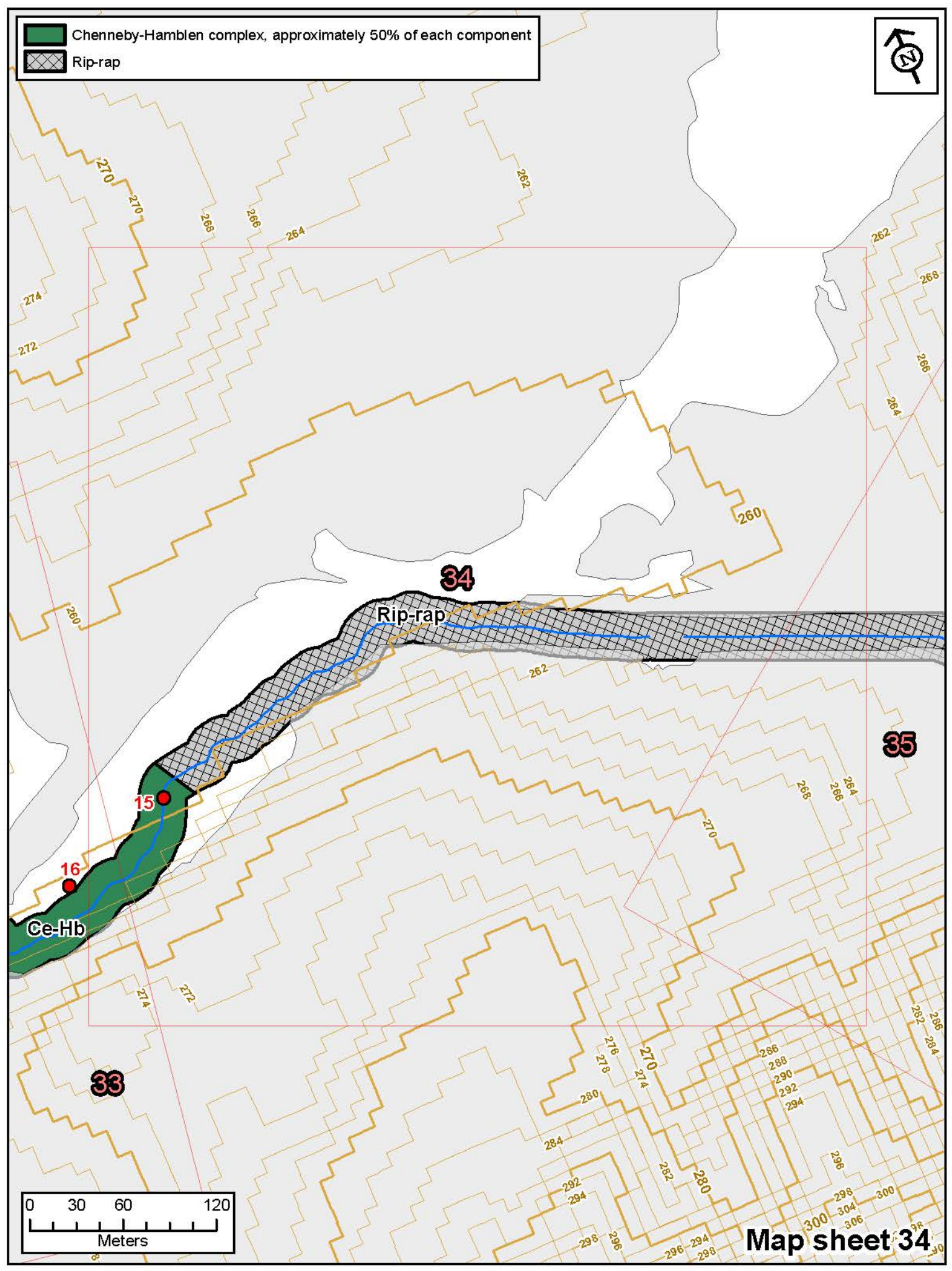

Fig. A.28. Map of soil types at bank locations 15-16 along lower East Fork Poplar Creek. 


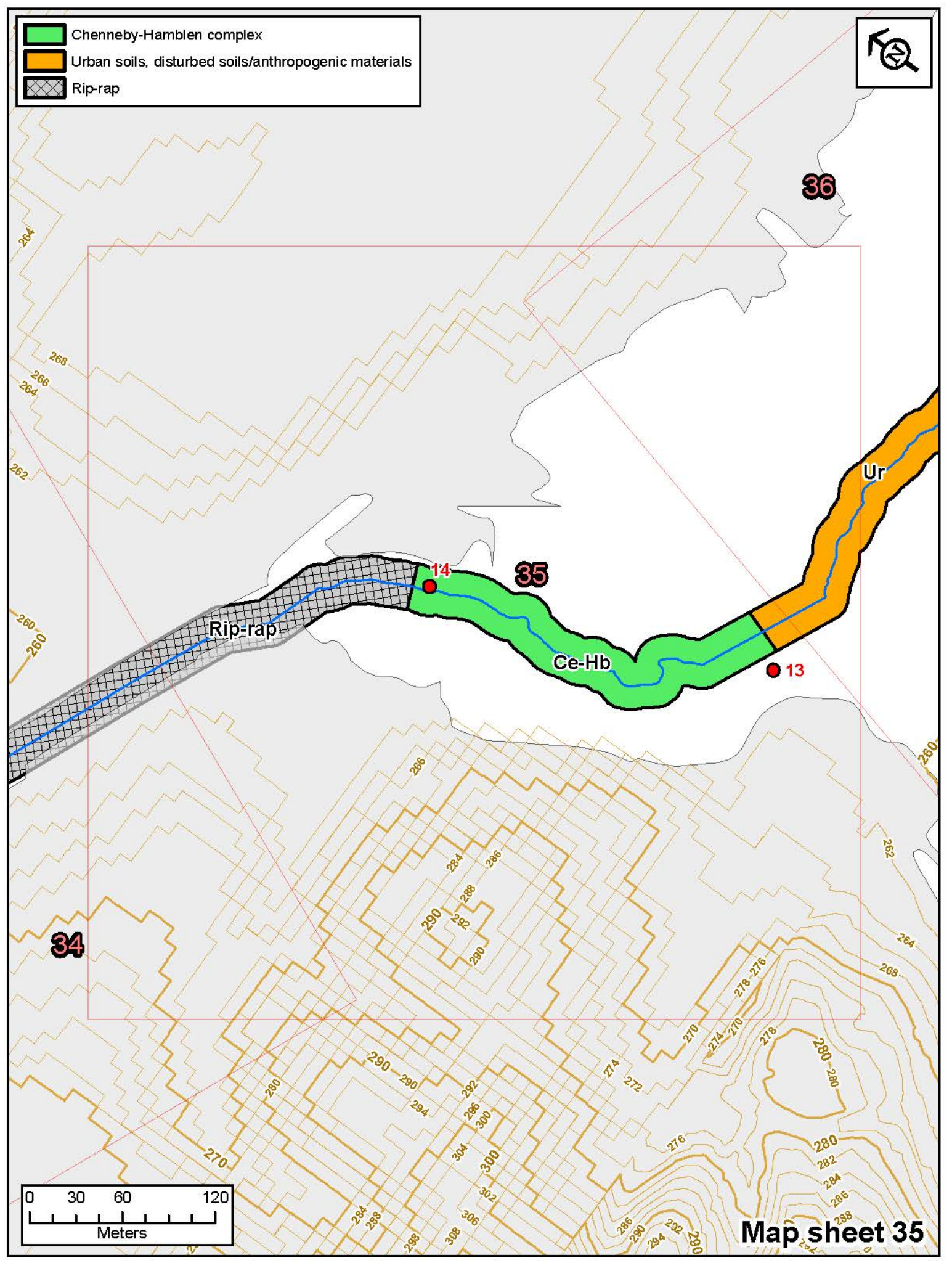

Fig. A.29. Map of soil types at bank locations 13-14 along lower East Fork Poplar Creek. 


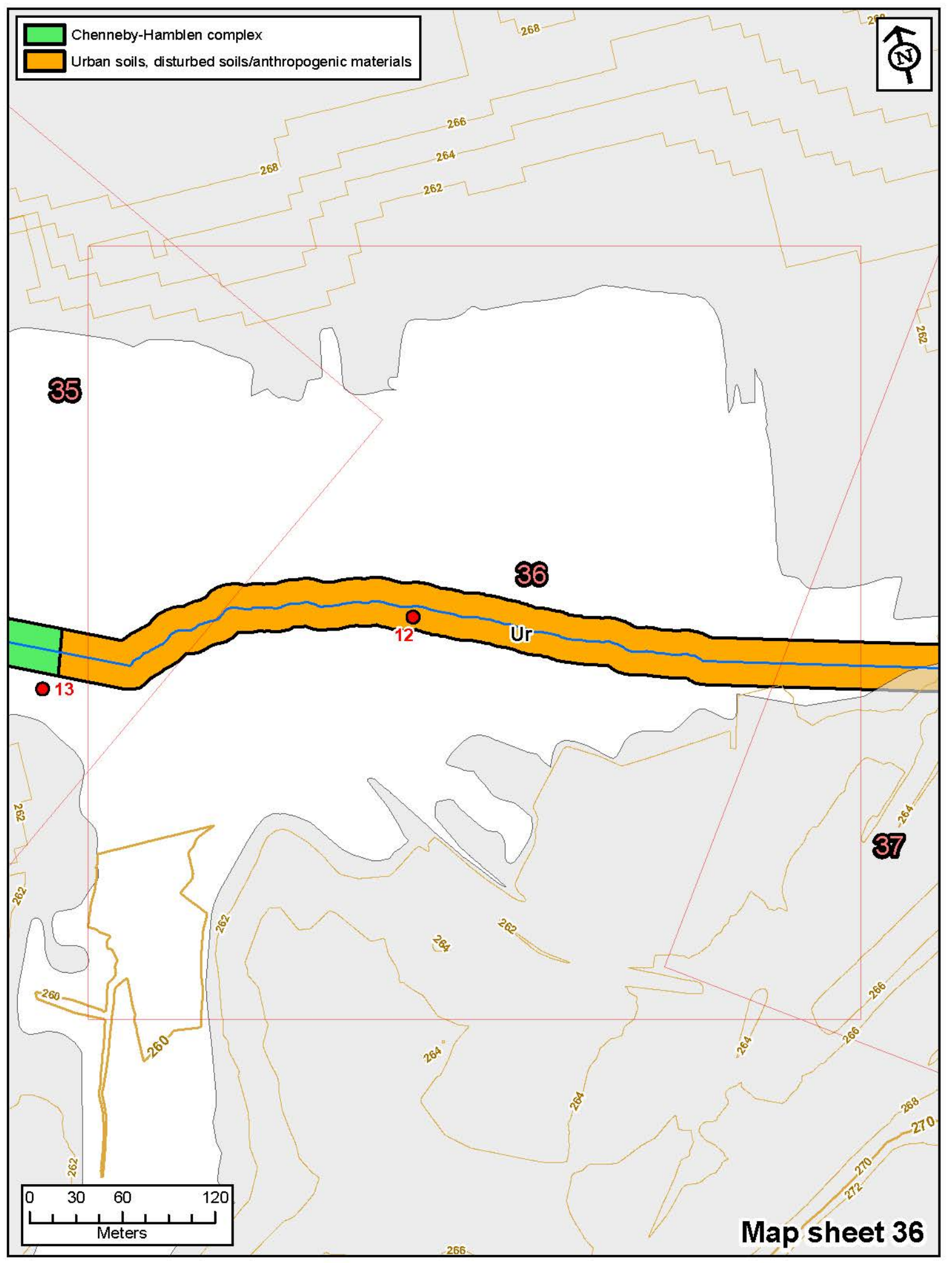

Fig. A.30. Map of soil types at bank locations 12-13 along lower East Fork Poplar Creek. 


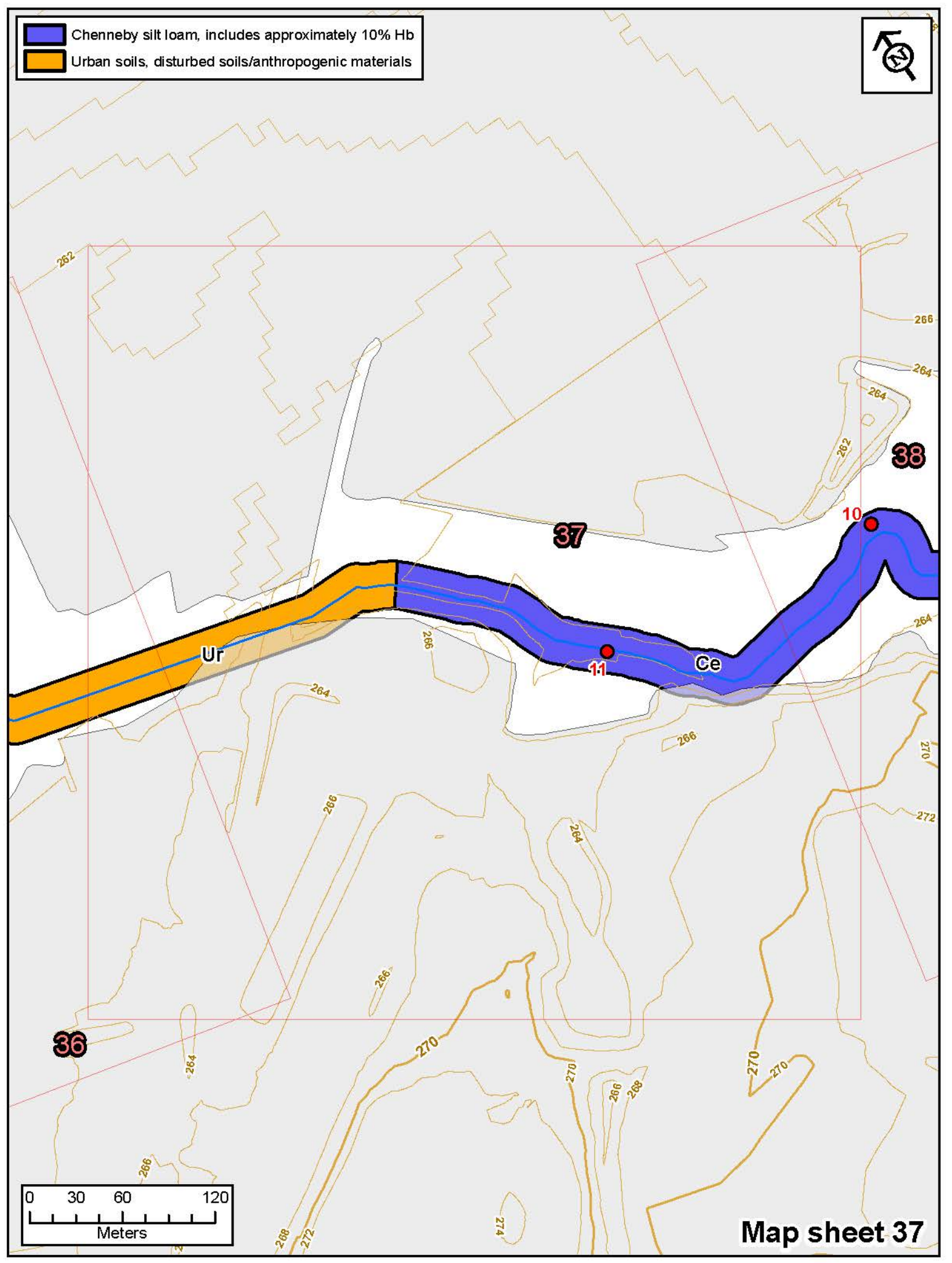

Fig. A.31. Map of soil types at bank locations 10-11 along lower East Fork Poplar Creek. 


$$
m
$$




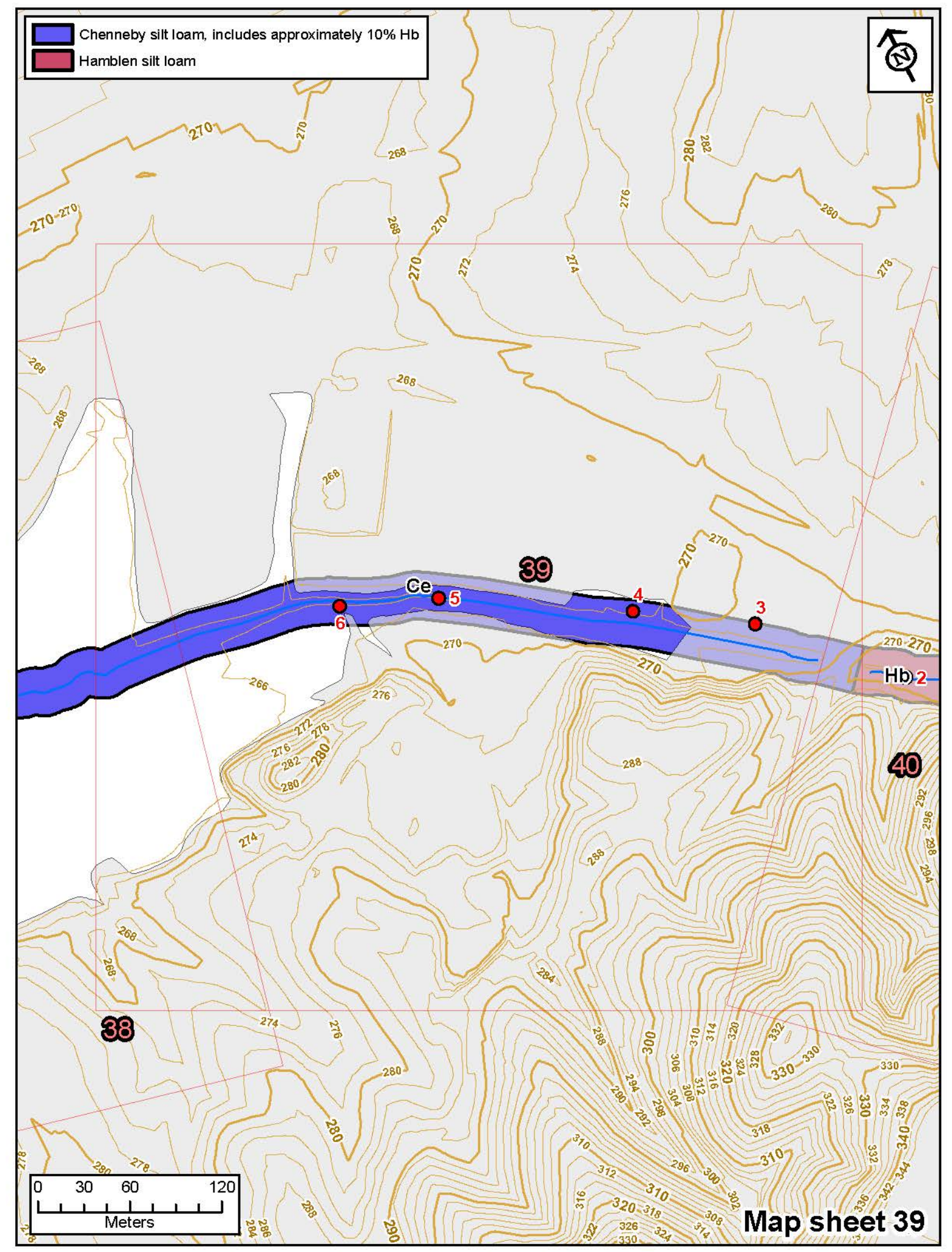

Fig. A.33. Map of soil types at bank locations 2-6 along lower East Fork Poplar Creek. 


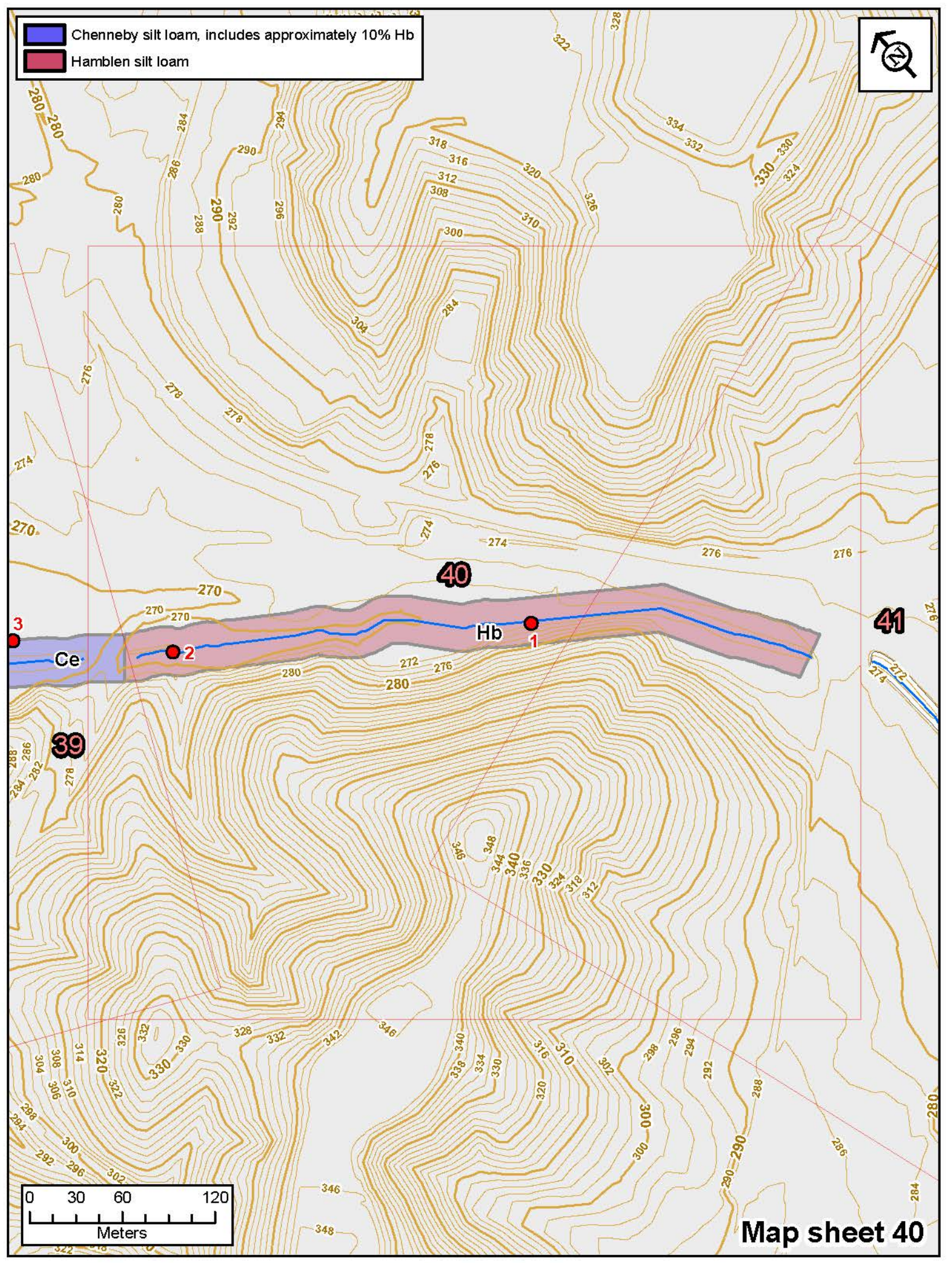

Fig. A.34. Map of soil types at bank locations 1-2 along lower East Fork Poplar Creek. 
APPENDIX B. SOIL PROFILE NOTES AND PICTURES 

APPENDIX B. SOIL PROFILE NOTES AND PICTURES

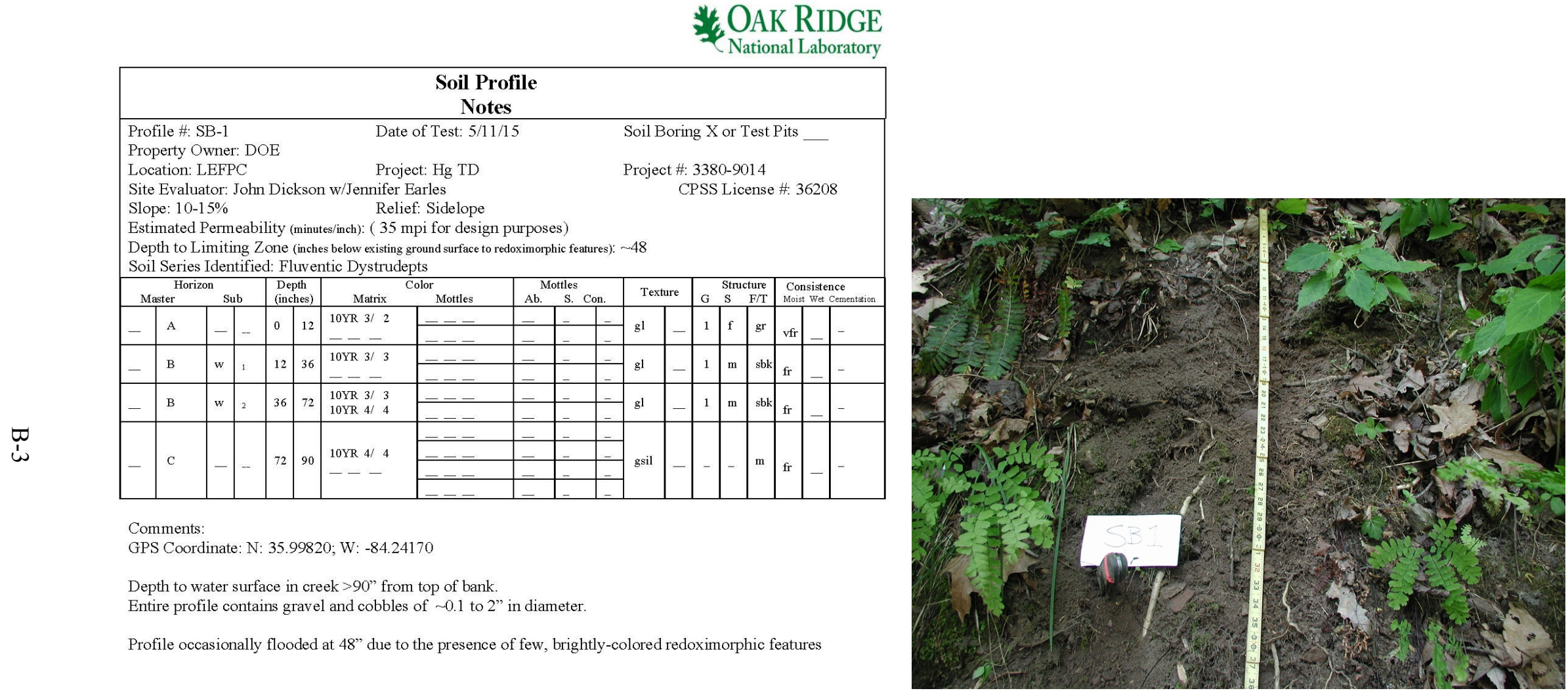




\section{OAK RIDGE \\ National Laboratory}

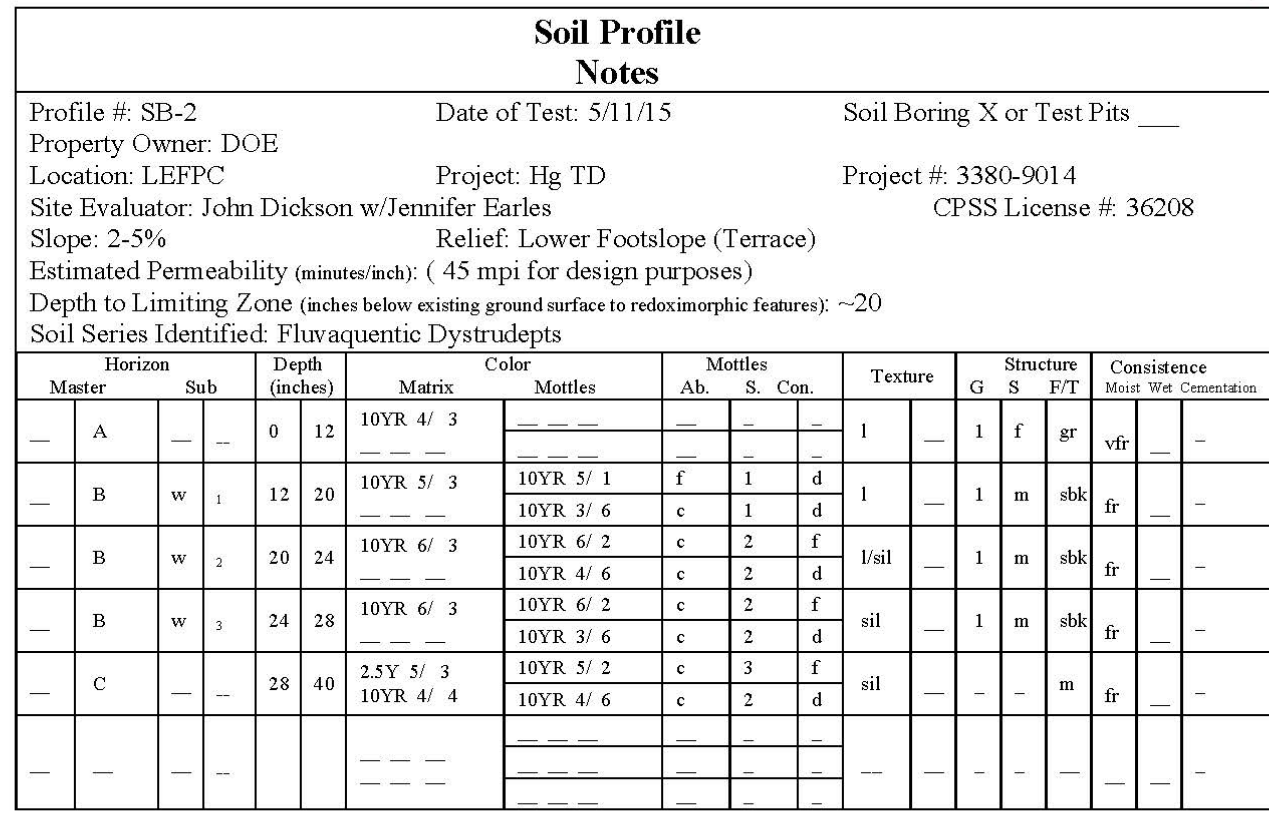

Comments

GPS Coordinate: N: $35.99951 ; \mathrm{W}:-84.24371$

From 12 " to $>40$ " gravel and cobbles of $\sim 0.1$ to 1 " in diameter.

Depth to water surface in creek 42 " from top of bank.

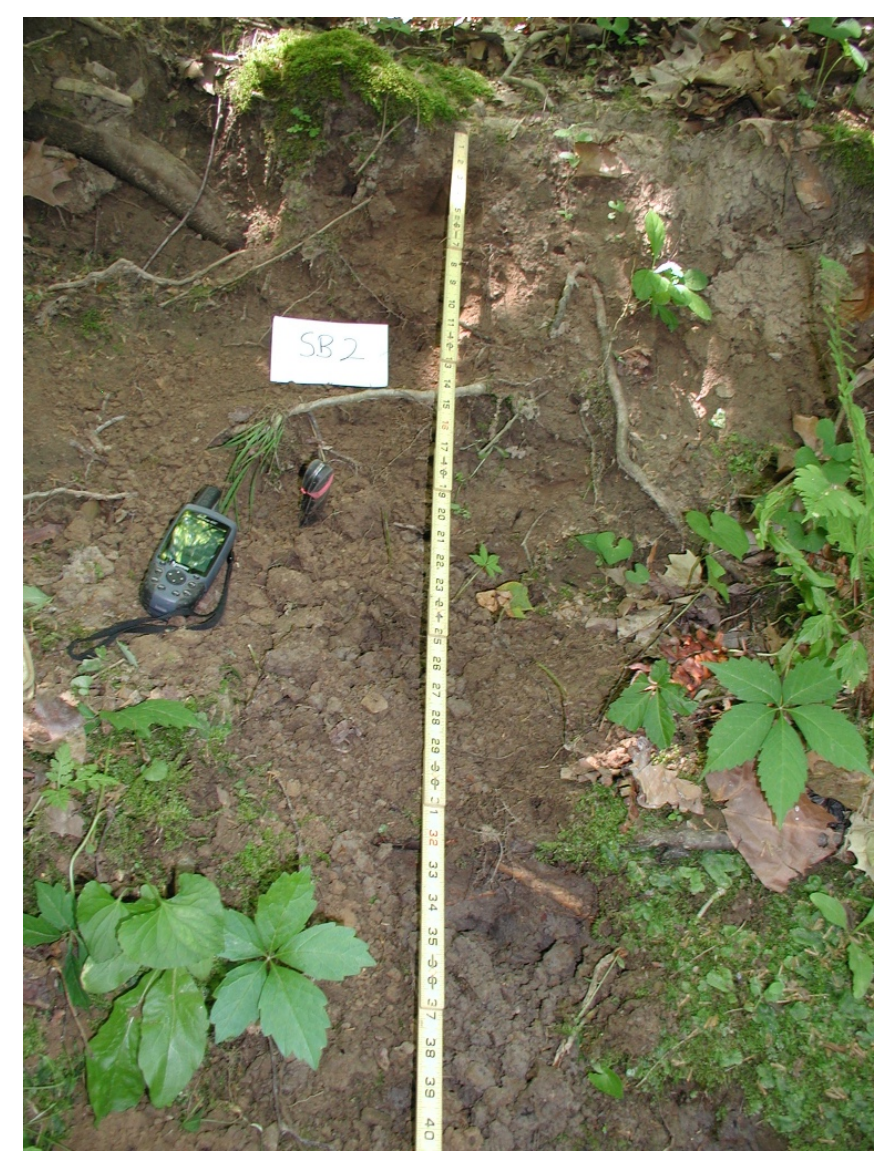

Site Evaluator's Signature: 
National Laboratory

\begin{tabular}{|c|c|c|c|c|c|c|c|c|c|c|c|c|c|c|c|c|c|c|}
\hline \multicolumn{19}{|c|}{$\begin{array}{c}\text { Soil Profile } \\
\text { Notes }\end{array}$} \\
\hline \multicolumn{19}{|c|}{ 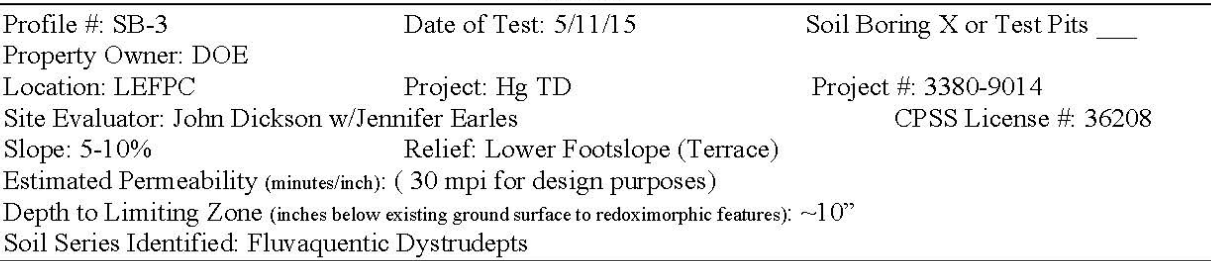 } \\
\hline \multicolumn{4}{|c|}{\begin{tabular}{cc}
\multicolumn{2}{c}{ Horizon } \\
Master & Sub \\
\end{tabular}} & \multicolumn{2}{|c|}{$\begin{array}{l}\begin{array}{l}\text { Depth } \\
\text { (inches) }\end{array} \\
\end{array}$} & \multicolumn{2}{|c|}{ Matrix $\quad{ }^{\text {Color }}$ Mottles } & \multicolumn{3}{|c|}{\begin{tabular}{|l|c}
\multicolumn{2}{|c}{ Mottles } \\
Ab. \\
S. Con.
\end{tabular}} & \multicolumn{2}{|c|}{ Texture } & \multicolumn{3}{|c|}{ 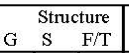 } & \multicolumn{3}{|c|}{$\begin{array}{l}\text { Consistence } \\
\text { Moist Wwet Cementition }\end{array}$} \\
\hline- & A & - & - & 0 & 10 & $\begin{array}{l}10 \mathrm{YR} 4 / 3 \\
---\end{array}$ & --- & $=$ & & - & 1 & - & 1 & f & $\mathrm{gr}$ & fr & & - \\
\hline- & B & $\mathrm{w}$ & - & 10 & 25 & $\begin{array}{l}10 \mathrm{YR} 4 / 2 \\
10 \mathrm{YR} 4 / 4\end{array}$ & $\frac{2.5 Y 5 / 2}{10 Y R \quad 4 / 6}$ & $\frac{c}{c}$ & & $\frac{f}{d}$ & $\mathrm{gl}$ & - & 1 & $\mathrm{~m}$ & sbk & $\mathrm{fr}$ & 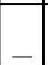 & - \\
\hline- & CB & - & - & 25 & 48 & $\begin{array}{l}2.5 \mathrm{Y} 4 / 4 \\
---\end{array}$ & $\begin{array}{l}2.5 \mathrm{Y} 5 / 2 \\
10 \mathrm{YR} 4 / 6\end{array}$ & $\frac{c}{c}$ & & $\frac{d}{d}$ & $\mathrm{gl}$ & - & 1 & $\mathrm{~m}$ & sbk & $\mathrm{fr}$ & & - \\
\hline- & - & - & - & & & $\begin{array}{l}--- \\
---\end{array}$ & --- & $=$ & & - & - & - & - & - & - & $=$ & 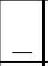 & - \\
\hline- & - & - & - & & & $\begin{array}{l}--- \\
---\end{array}$ & $=--$ & & & - & - & - & - & - & - & - & $=$ & - \\
\hline- & - & - & -- & & & $\begin{array}{l}--- \\
--\end{array}$ & & & & & - & - & - & - & - & & - & - \\
\hline
\end{tabular}

Comments:

GPS Coordinate: N: $36.0002 ; \mathrm{W}:-84.24449 \pm 34^{\prime}$

From $10 "$ to $>48$ " gravel and cobbles of $\sim 0.1$ to $1 "$ in diameter. Bedrocks at 48 "

Depth to water surface in creek $\sim 48$ " from top of bank.

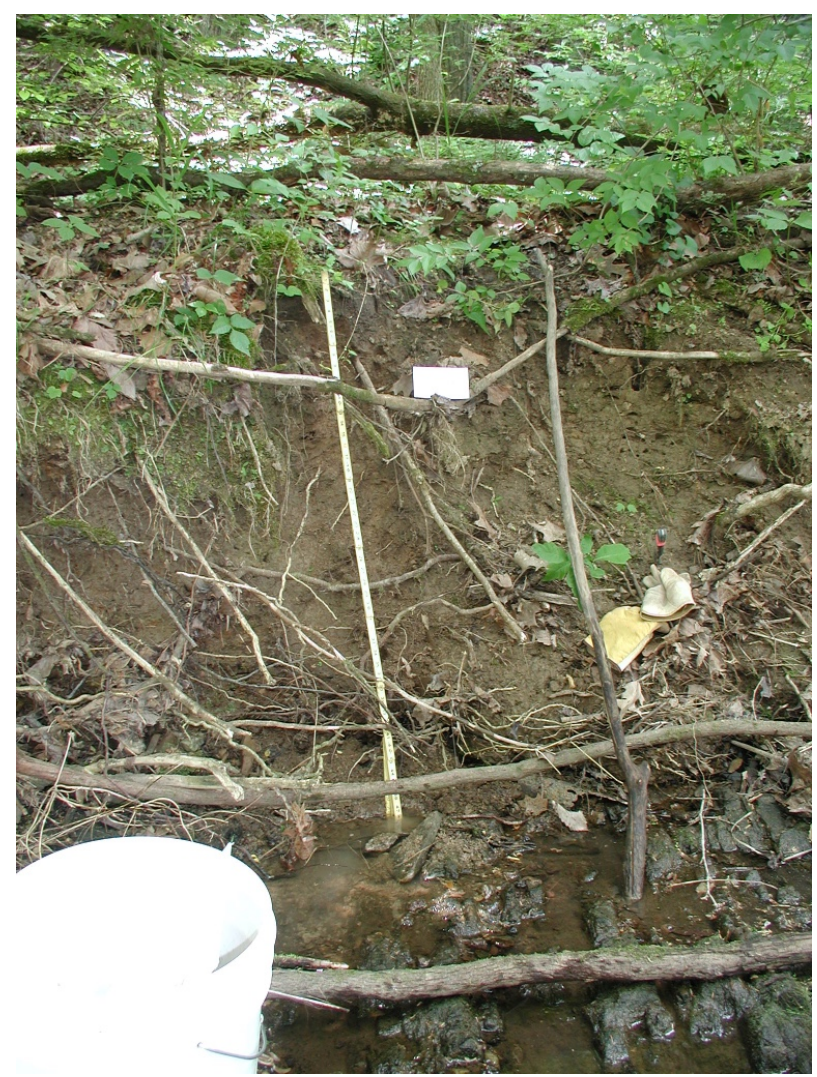

Site Evaluator's Signature: 


Soil Profile
Notes

Comments:

GPS Coordinate: N: 36.00060 , W: $-84.24523 \pm 15$

At 11-18" few pockets of clay (c); many black (Mn) concretions, 10YR 2/1.

At 18-27" lenses of coarse loamy sand

At 36-66" inclusion of gravels, cobbles, $~ 50 \%$ of horizon; many black (Mn) concretions, 10 YR 2/1

At 66" and greater, gravels and cobbles with clays inclusion

Depth to water surface in creek -66 " from top of bank.

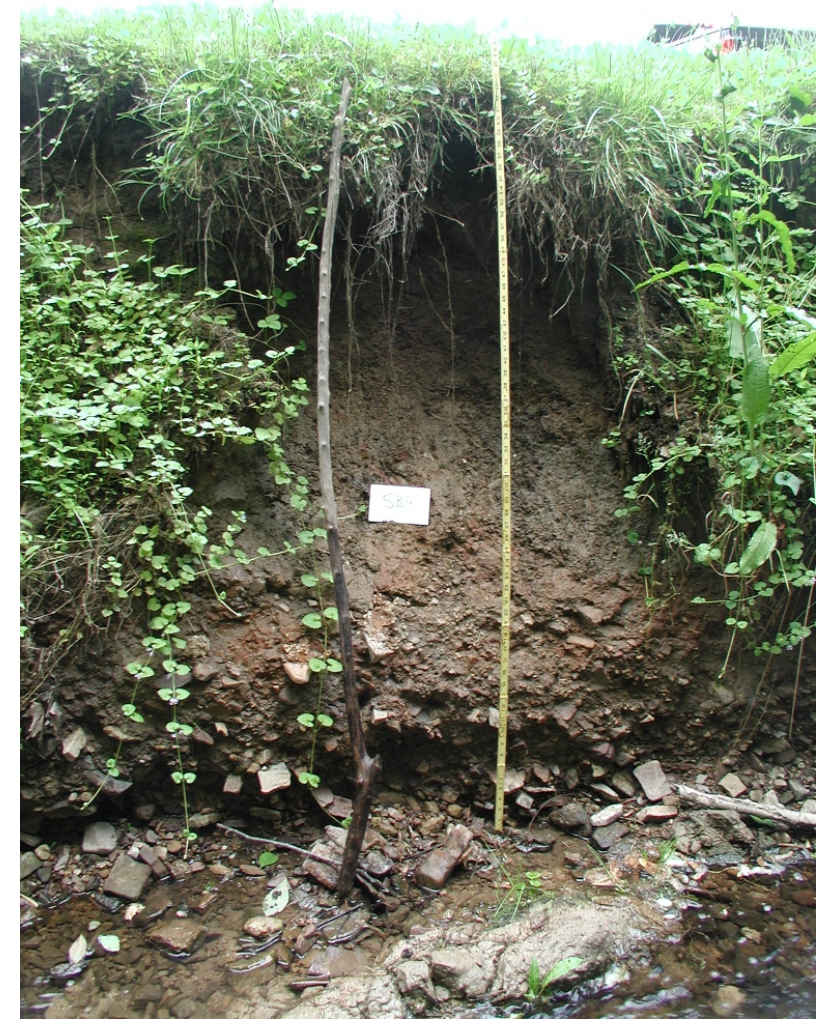

Site Evaluator's Signature: 


Soil Profile
Notes

Comments:

GPS Coordinate: N: $36.00120 ; \mathrm{W}:-84.24643$

At 7-15" many black (Mn) concretions, 10YR 2/1. "Black layer" observed

Depth to water surface in creek $>80^{\prime \prime}$ from top of bank.

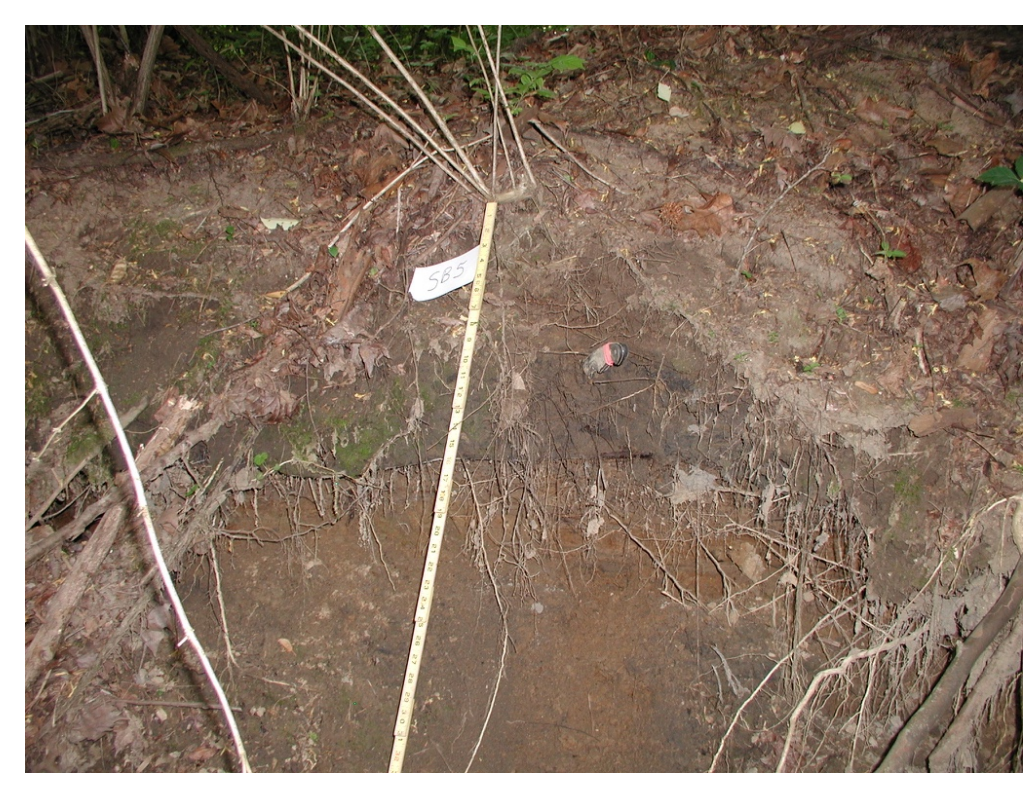




\section{NaAK RIDGE}

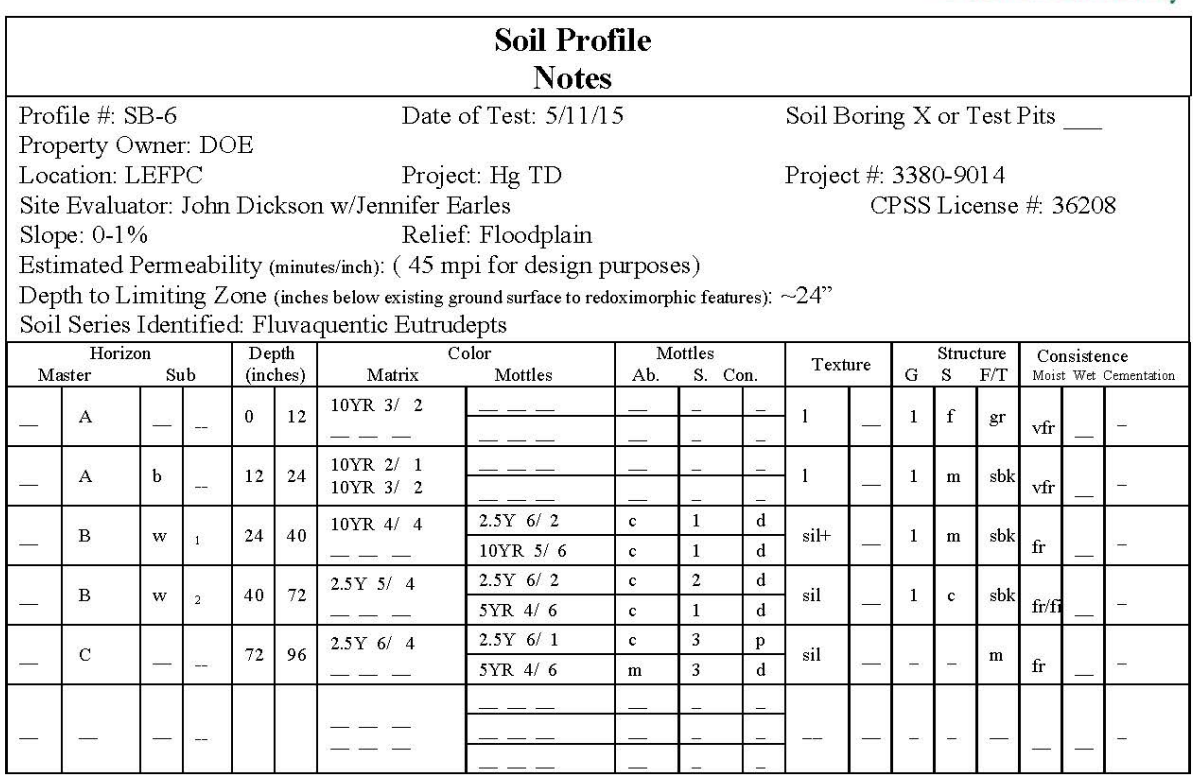

Comments:

GPS Coordinate: N: 36.00143 ; W: -84.24709

At 12-24" many black (Mn) concretions, 10YR 2/1, "Black layer" observed At 72-96" few inclusions of gravels

Below 96" very firm and gleyed clay horizon

Depth to water surface in creek $>96$ " from top of bank.

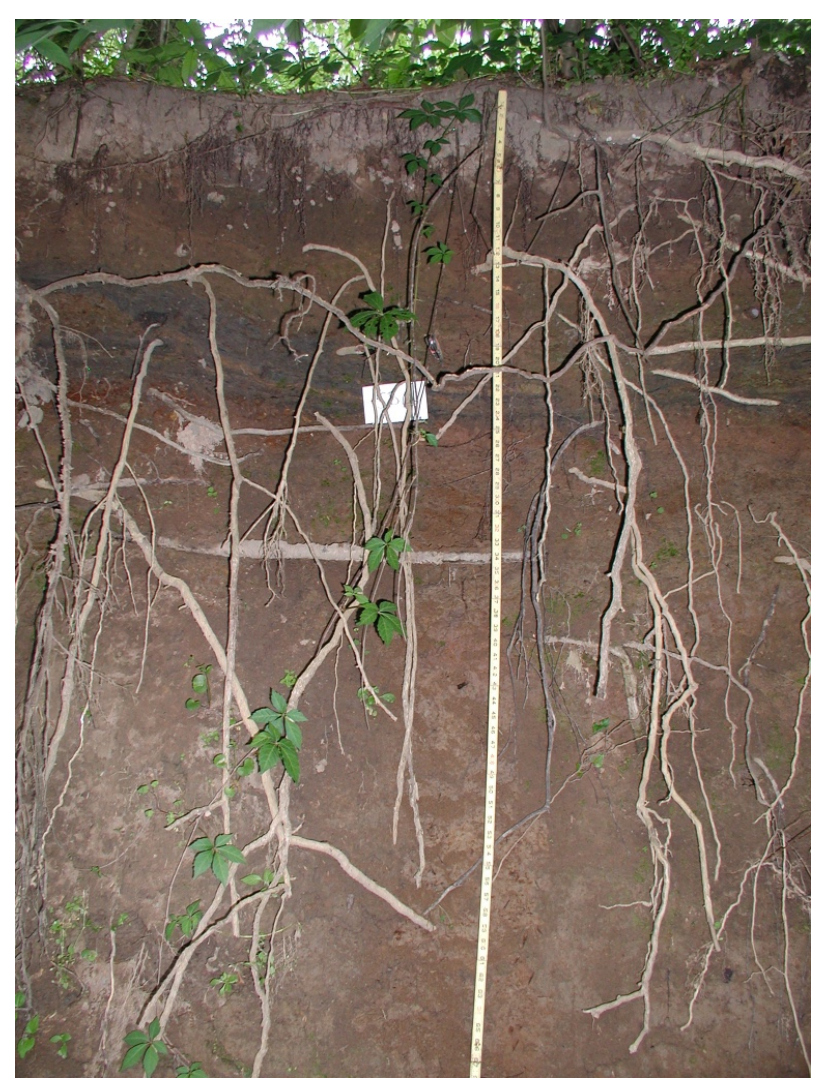




\begin{tabular}{|c|c|c|c|c|c|c|c|c|c|c|c|c|c|c|c|c|c|c|}
\hline \multicolumn{18}{|c|}{$\begin{array}{c}\text { Soil Profile } \\
\text { Notes }\end{array}$} & \\
\hline \multirow{2}{*}{\multicolumn{19}{|c|}{ 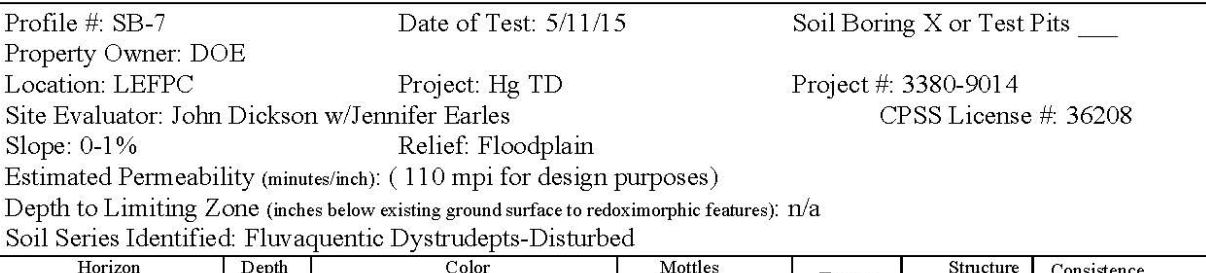 }} \\
\hline $\begin{array}{l}\text { Master Horizon } \\
\text { Sub }\end{array}$ & & & & & & & & & & & & & & & & & & \\
\hline- & FLL & - & -- & 0 & 16 & $10 \mathrm{YrR} 4 / 4$ & & $=$ & - & - & 1 & - & & & $\mathrm{m}$ & $\mathrm{fr} / \mathrm{f}$ & . & - \\
\hline- & в & w & -- & 16 & 32 & $2.5 \mathrm{Y} 4 / 4$ & \begin{tabular}{|l|} 
10YR $6 / 2$ \\
$10 \mathrm{YR} 5 / 6$
\end{tabular} & & $\frac{1}{2}$ & $\frac{d}{d}$ & sil & - & & & & fi & & - \\
\hline- & c & $\mathrm{g}$ & - & 32 & 38 & $\begin{array}{l}2.5 \mathrm{Y} 5 / 2 \\
2.5 \mathrm{Y} 5 / 4 \\
\end{array}$ & 5YR $4 / 6$ & c & 1 & $d$ & cl & - & & & & frof & & - \\
\hline- & - & - & - & & & --- & $-\ldots$ & - & & - & -- & - & & & & & . & - \\
\hline- & - & - & - & & & $-z_{-}-$ & -- & - & - & - & -- & - & & & - & & . & - \\
\hline- & - & - & - & & & -ニ- & & & & - & -- & - & & & & & & - \\
\hline
\end{tabular}

No photo

Comments:

GPS Coordinate: N: 36.00197 ; W: -84.24960

SB location appears to be previously remediated area covered with $\sim 16$ " fill material At 32-38" some inclusion of gravels

Depth to water surface in creek $\sim 38$ " from top of bank. 


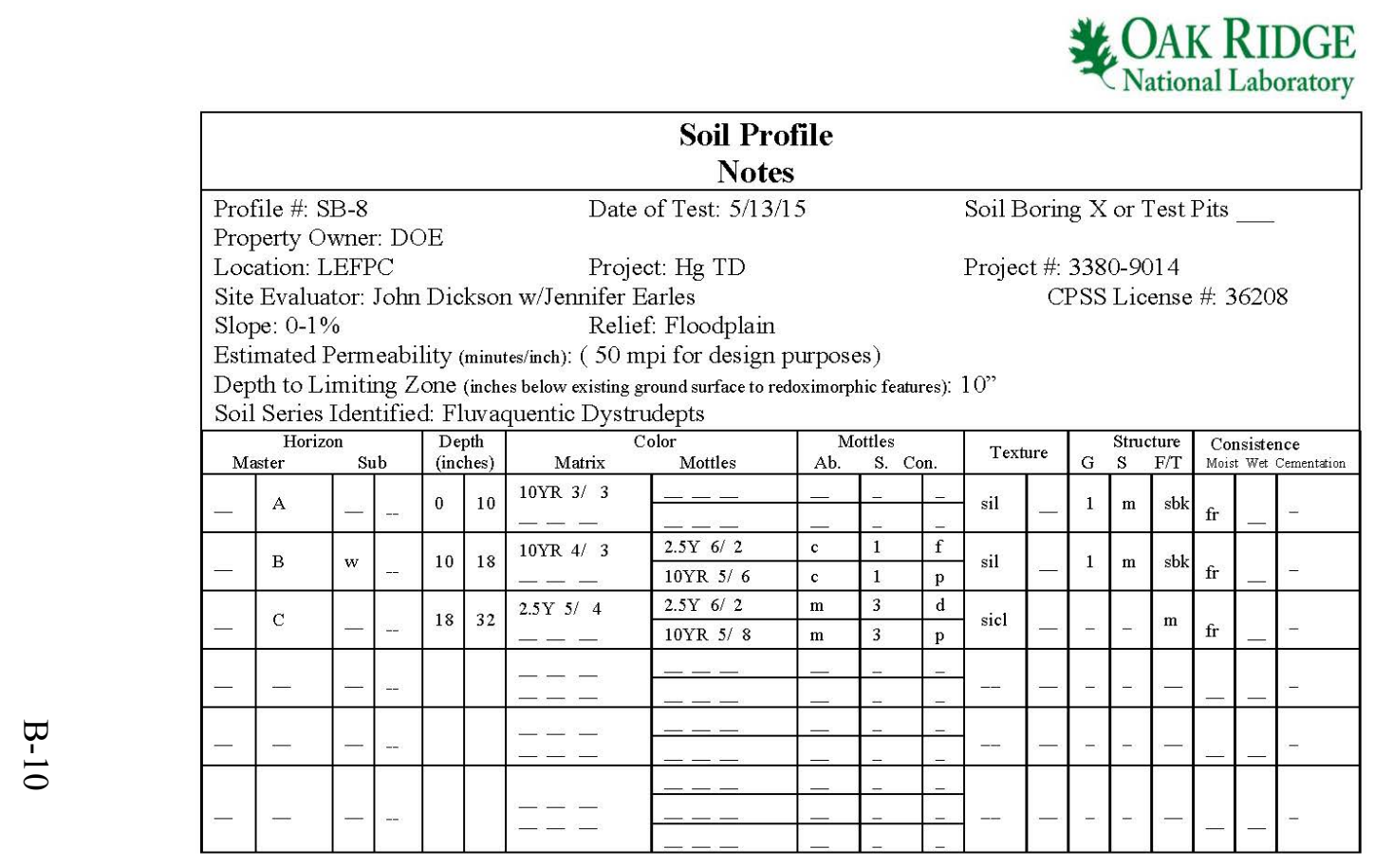

Comments:

GPS Coordinate: N: 36.00179; W: -84.25079

Firm, gleyed clayey (Cg) horizon at 32" and greater.

SB location prone to erosional deposition. Many gravels/pebbles observed in creek bed.

Depth to water surface in creek 32 " from top of bank.

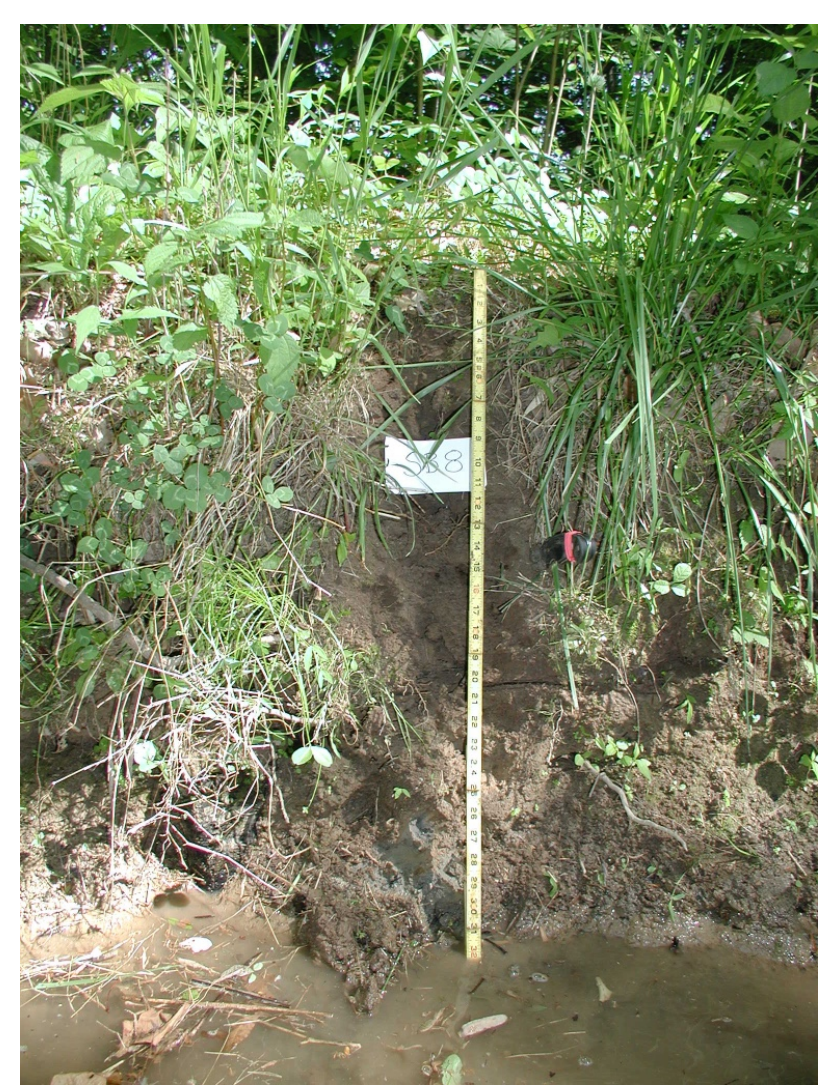




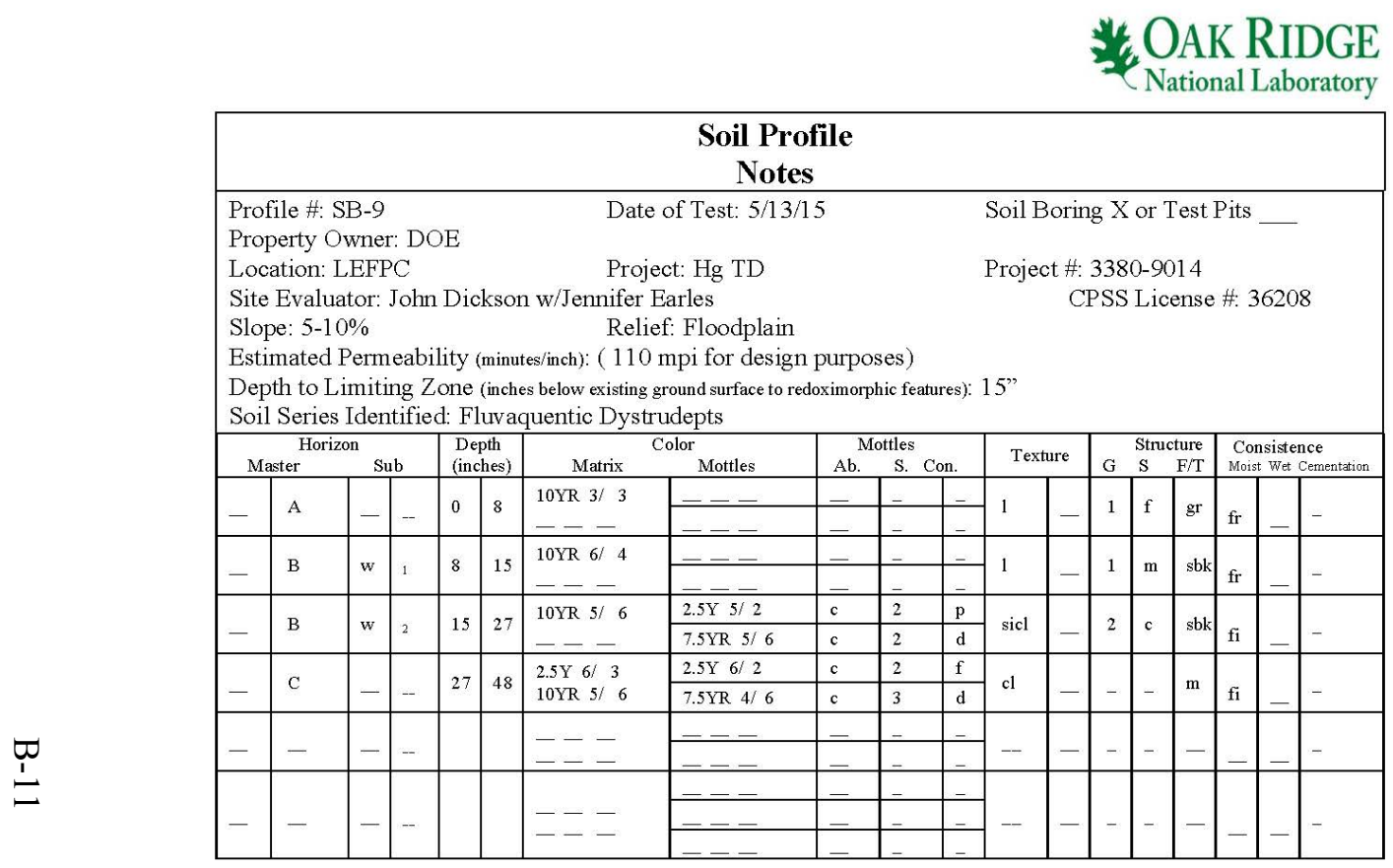

Comments:

GPS Coordinate: N: 36.00192 ; W: $-84.25185 \pm 10^{\circ}$

SB location prone to erosional deposition. Fallen trees observed.

From $15-27$ " inclusion of pockets of black Mn masses, 10YR 2/1

At 48 " firm, gleyed clay containing some gravels/cobbles

Depth to water surface in creek 48 " from top of bank.

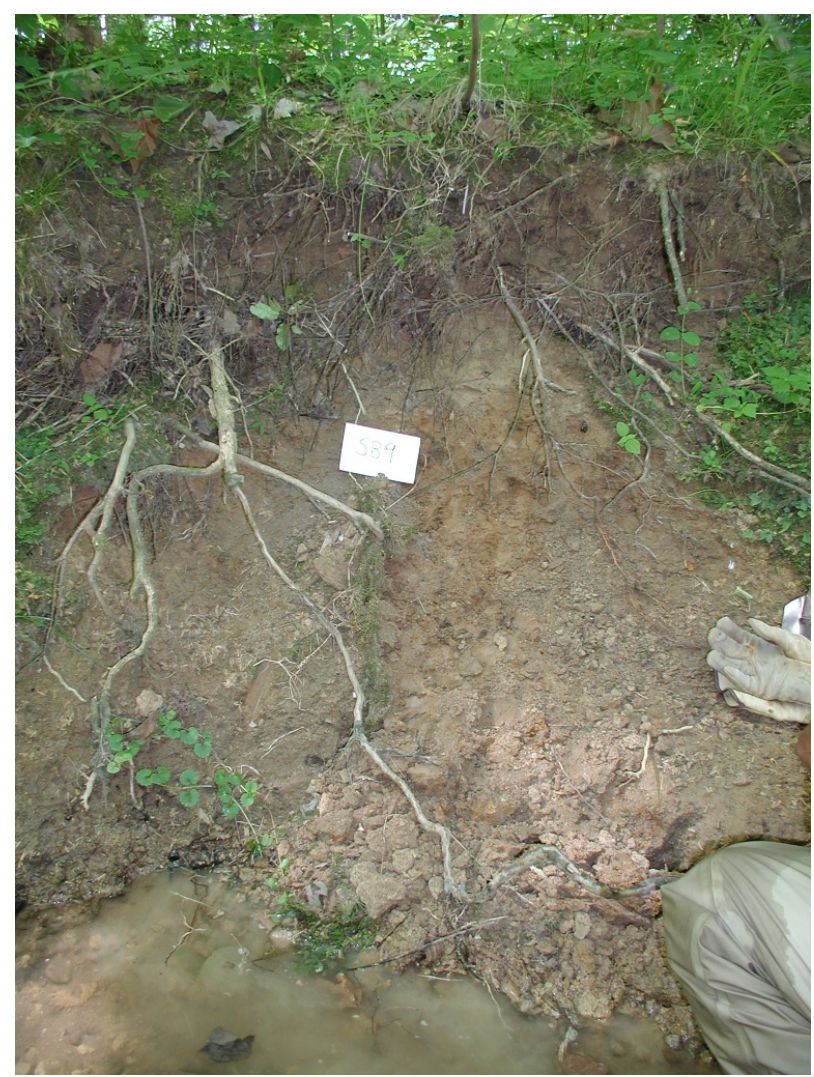




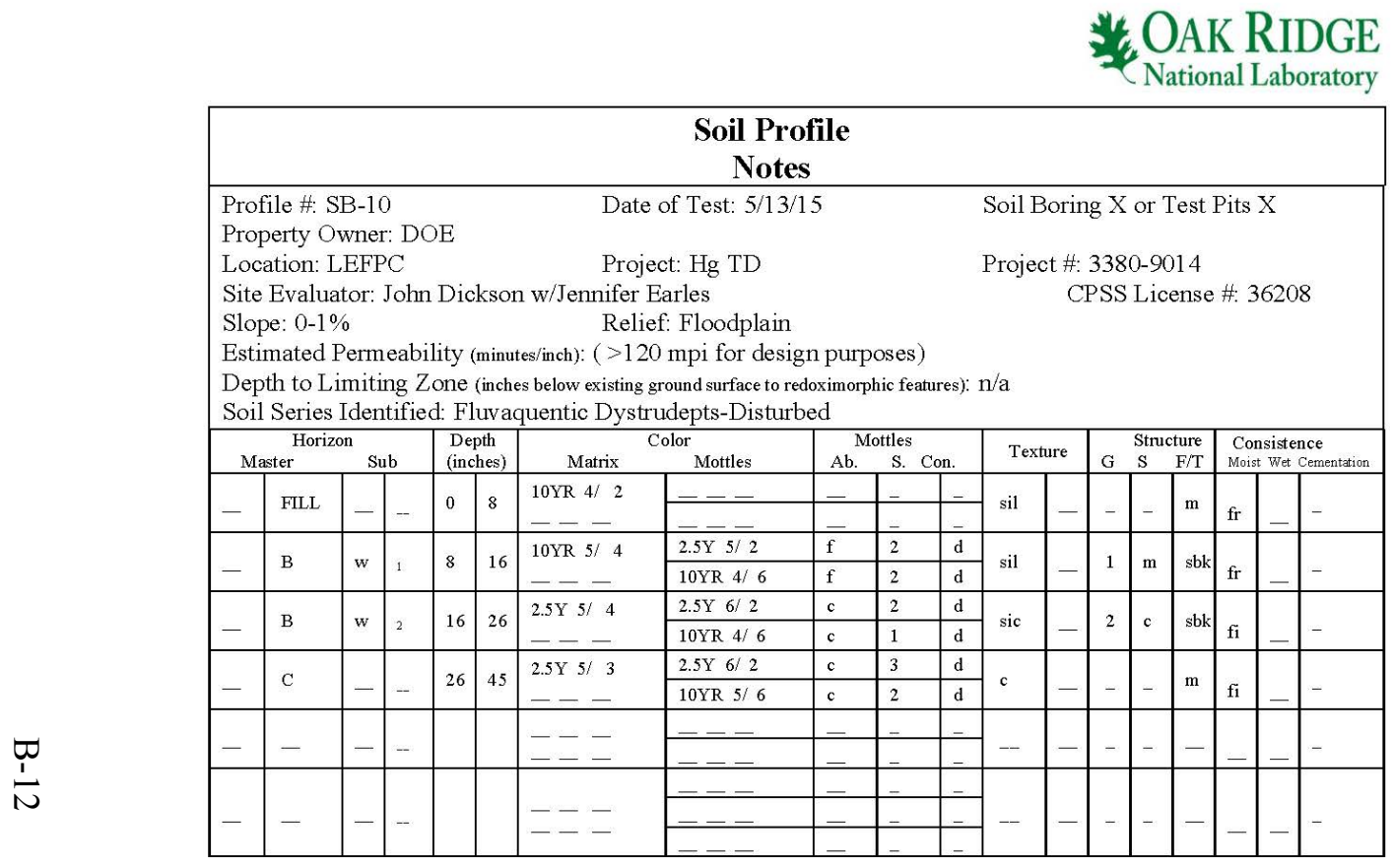

Comments:

GPS Coordinate: N: 36.00263 ; W: -84.25278

SB location located within previously remediated area.

From 26-45" inclusion of few gravels.

At 48 " firm, gleyed clayey horizon containing some cobbles

Depth to water surface in creek $\sim 45^{\prime \prime}$ from top of bank.

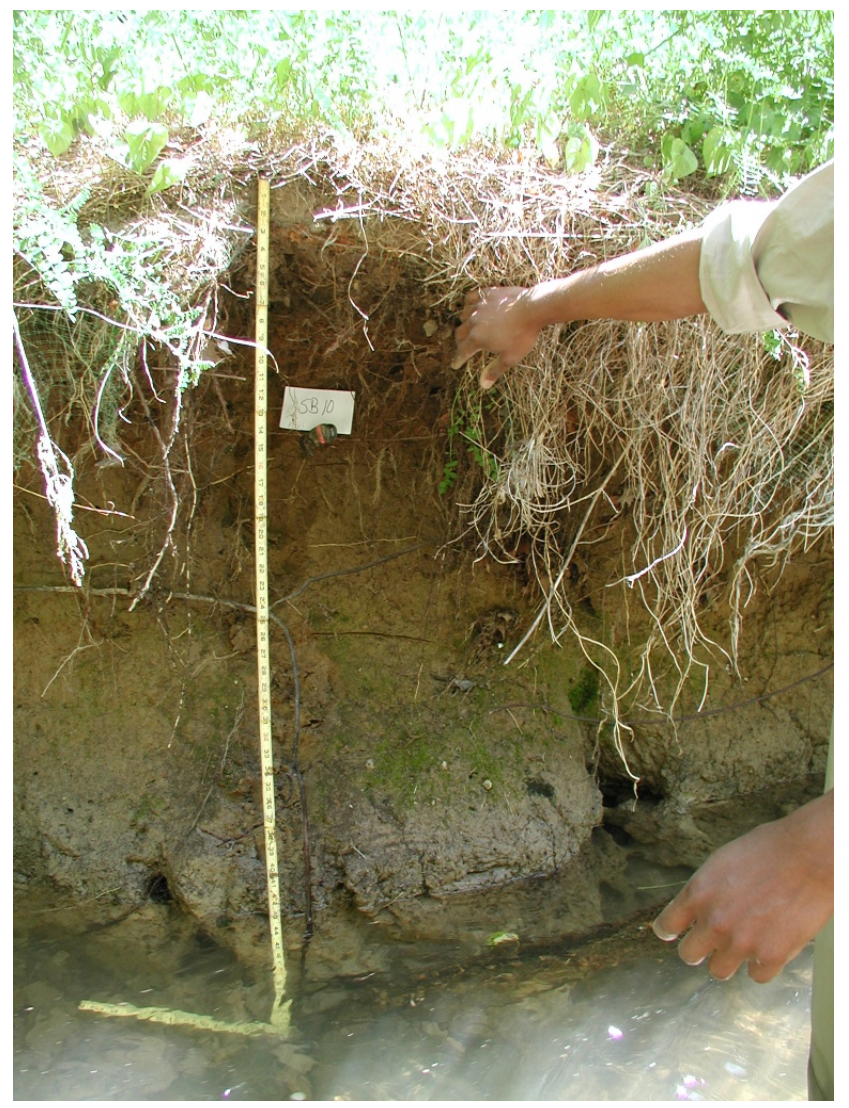




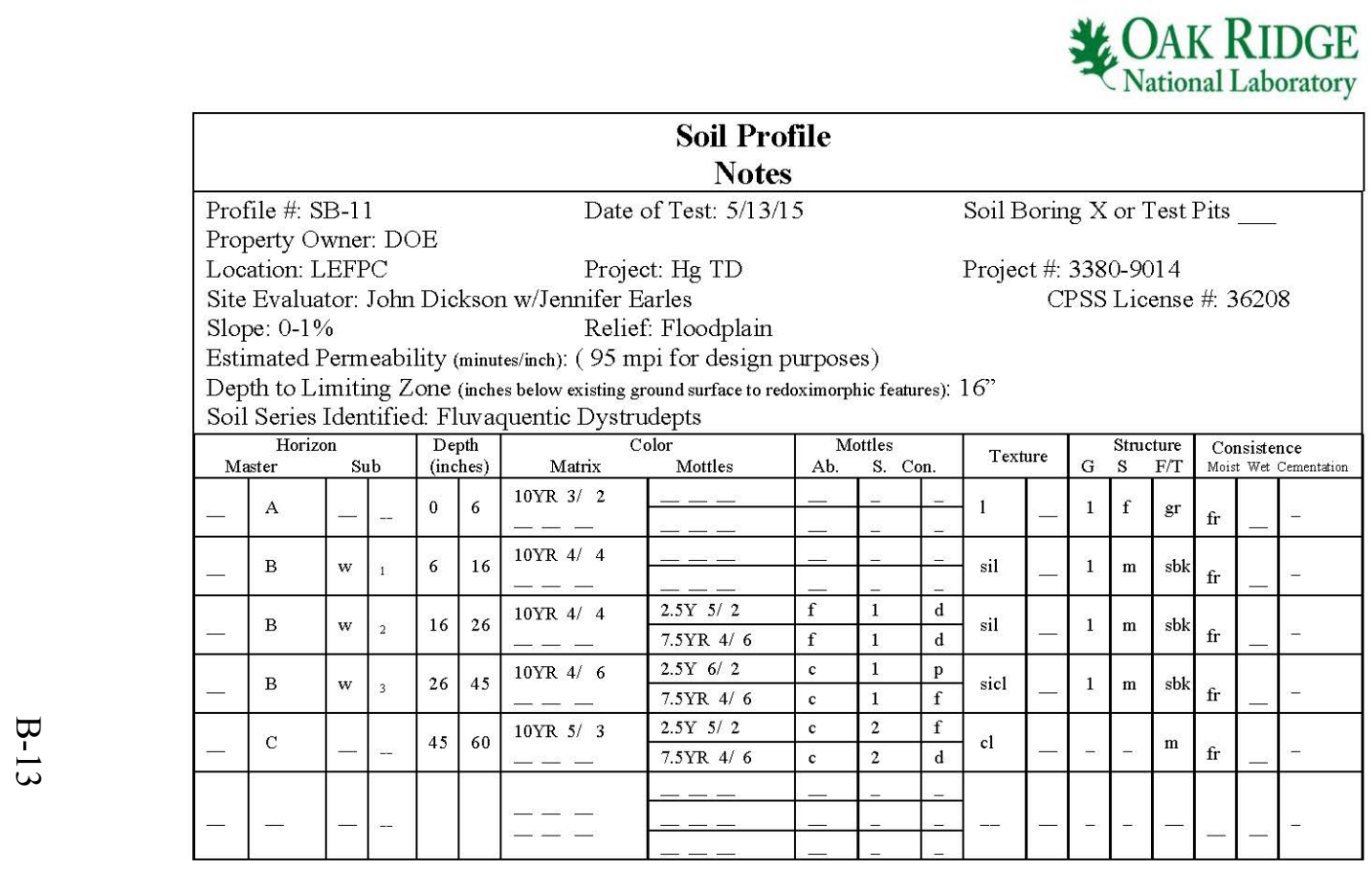

Comments:

GPS Coordinate: N: 36.00293 ; W: $-84.25485 \pm 9.4$ '

Depth to water surface in creek $\sim 60$ " from top of bank.

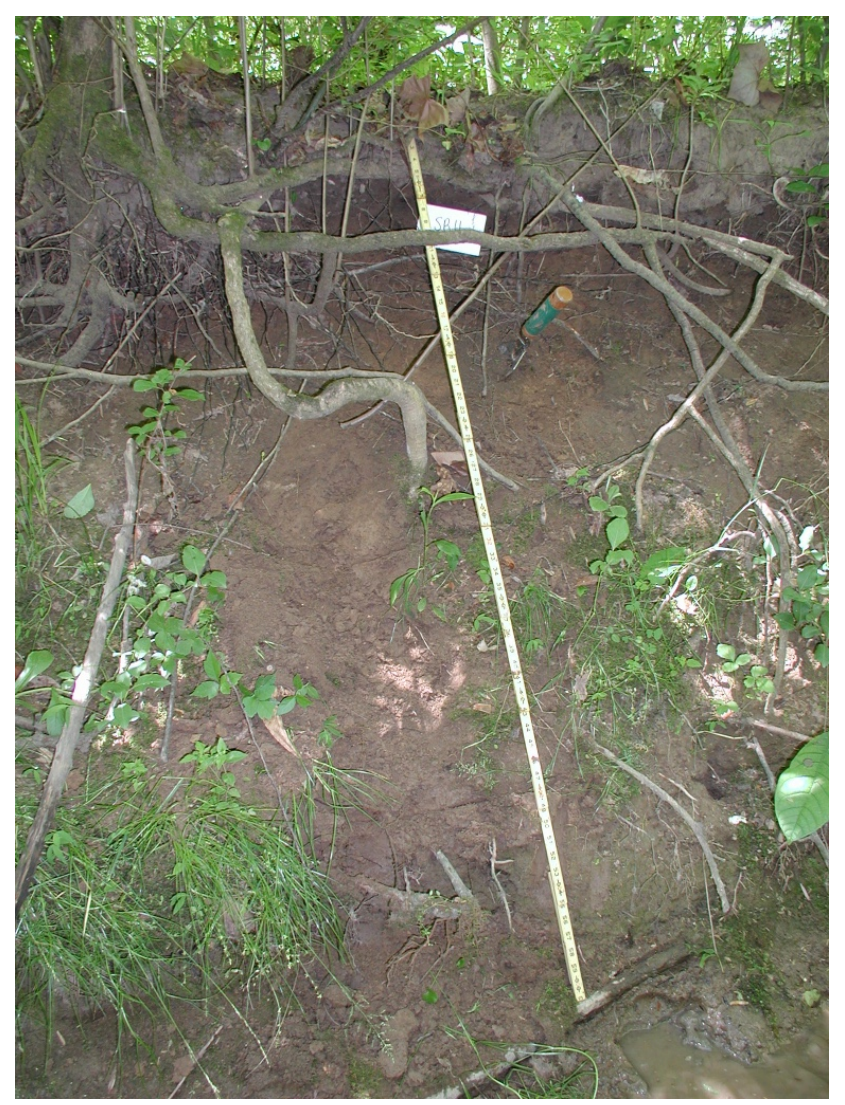




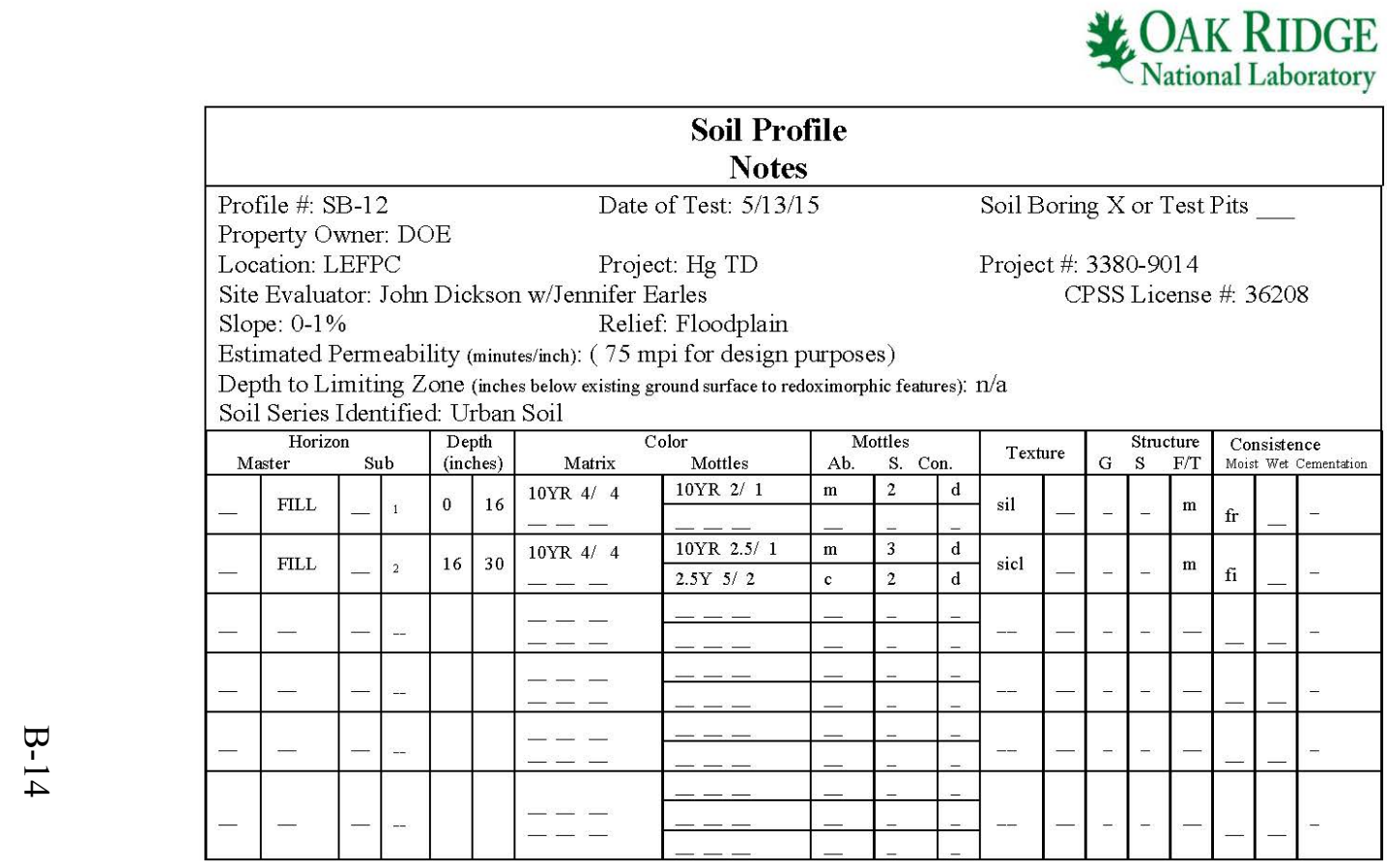

Comments:

GPS Coordinate: N: $36.00532 ; \mathrm{W}:-84.26051$

Disturbed urban soil. Entire swath of stream bank appears to be anthropogenic materials

Depth to water surface in creek $\sim 30$ " from top of bank.

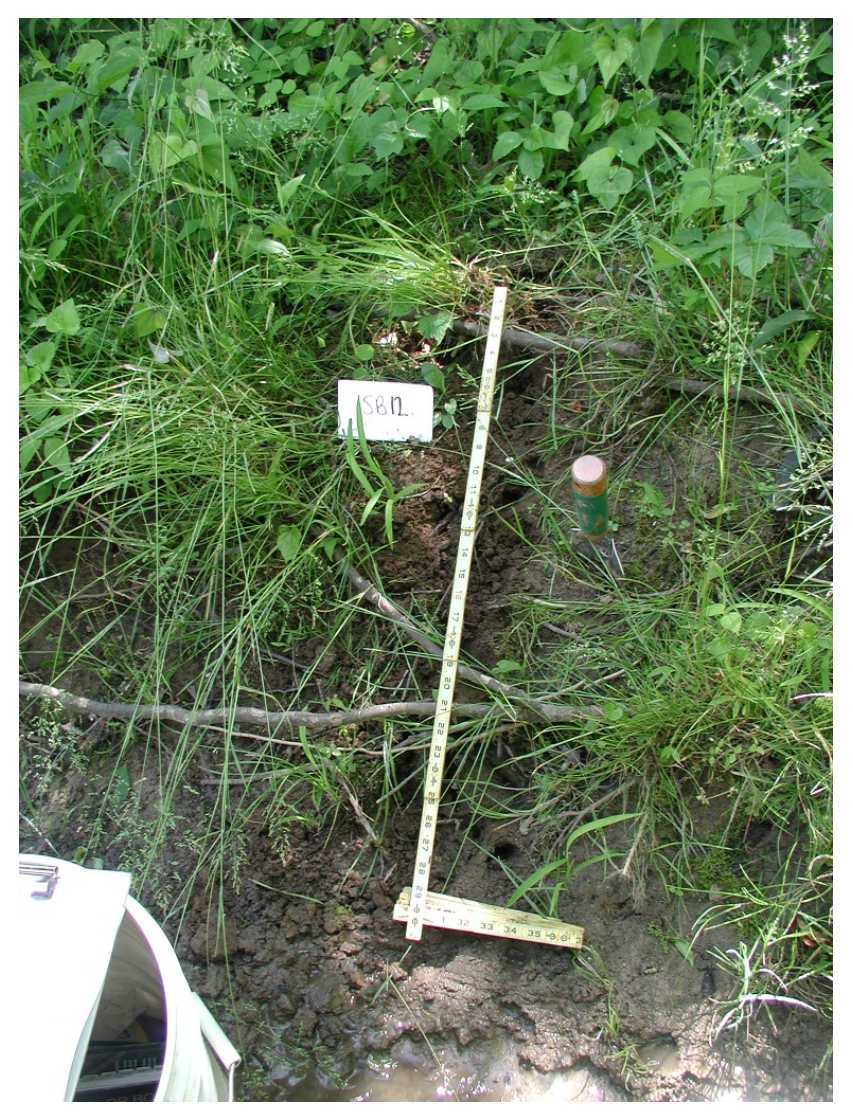




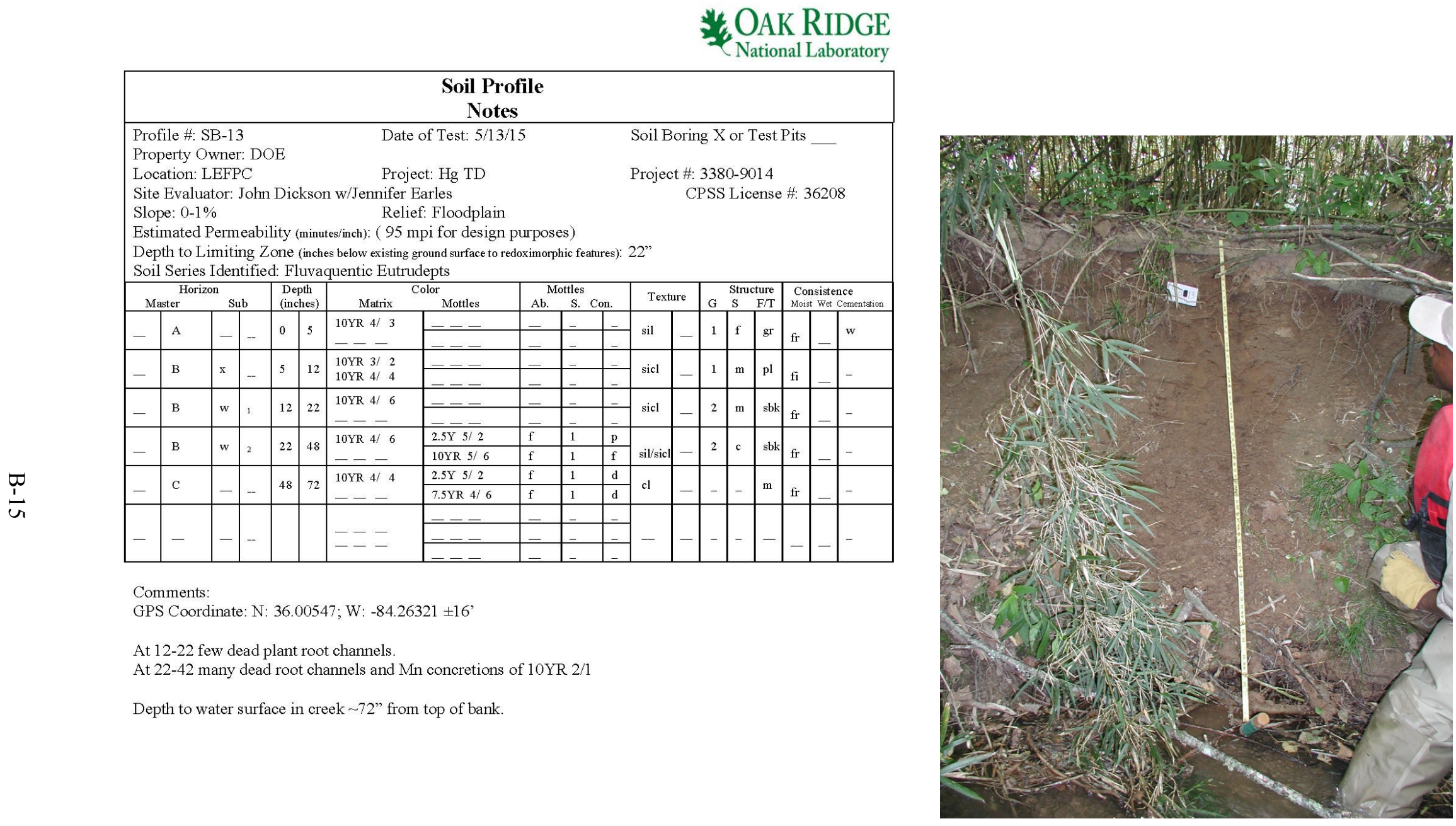

Site Evaluator's Signature 


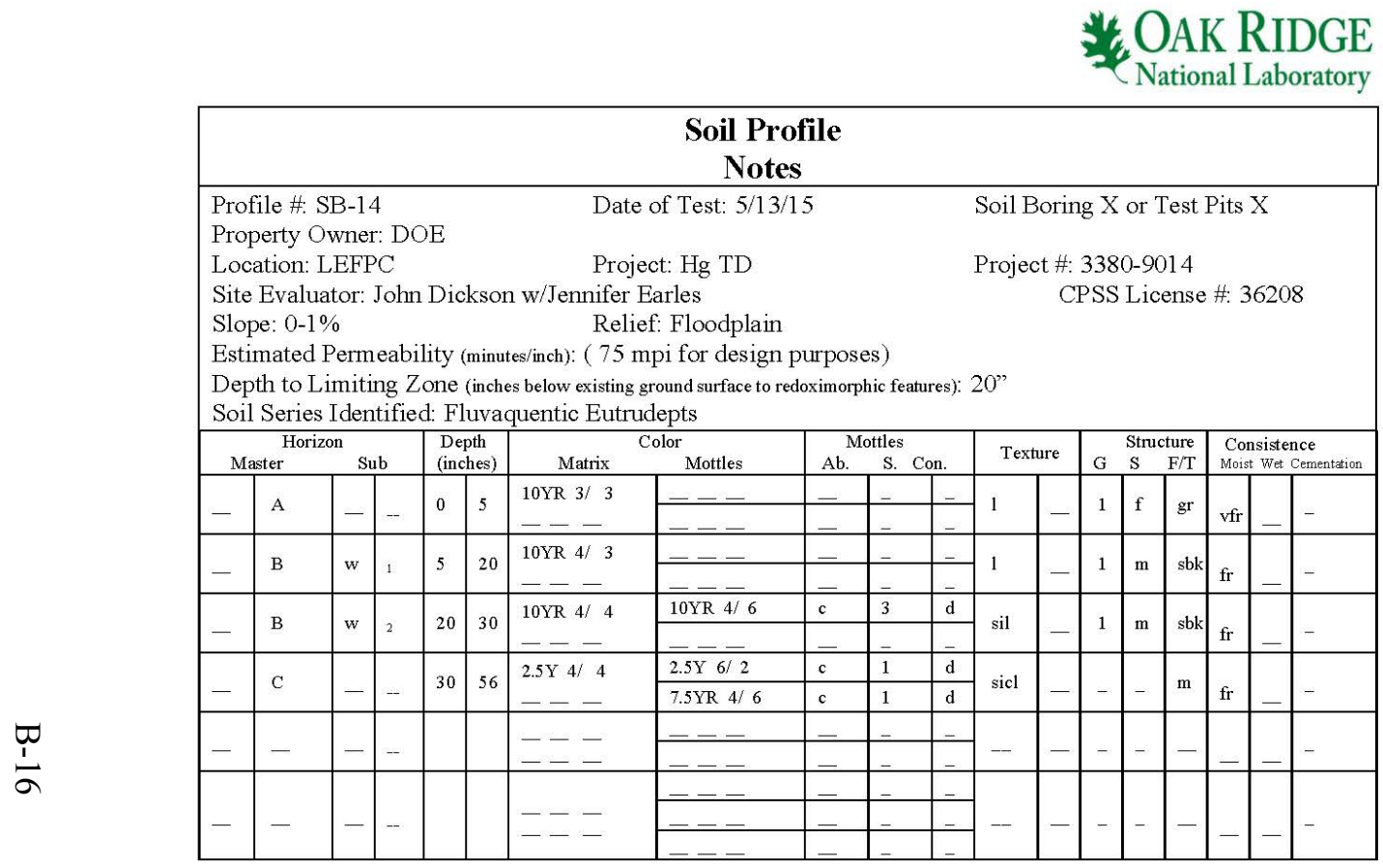

Comments:

GPS Coordinate: N: 36.00739 ; W: $-84.26414 \pm 12$

Depth to water surface in creek $~ 56$ " from top of bank.

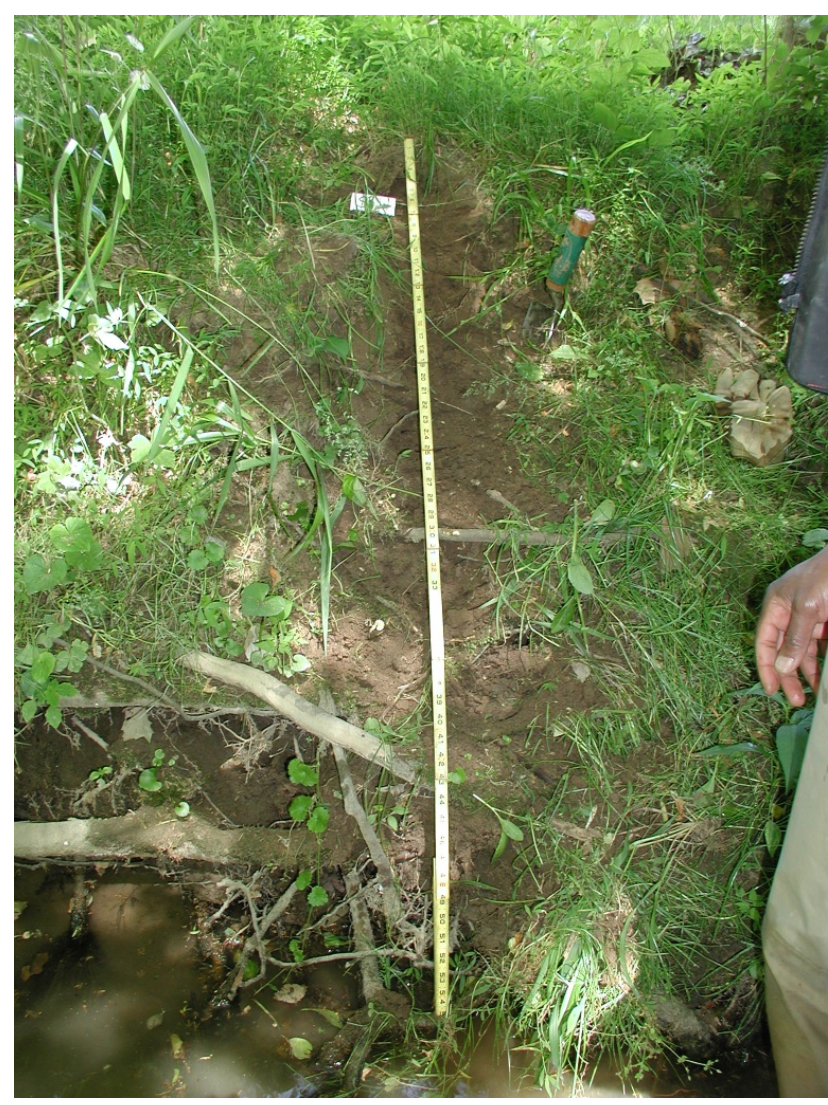




Soil Profile
Notes

Comments:

GPS Coordinate: N: 36.00924 : W: -84.27075

At 22-24" dark thin layer, 10YR 3/2.

Depth to water surface in creek $\sim 64$ " from top of bank.

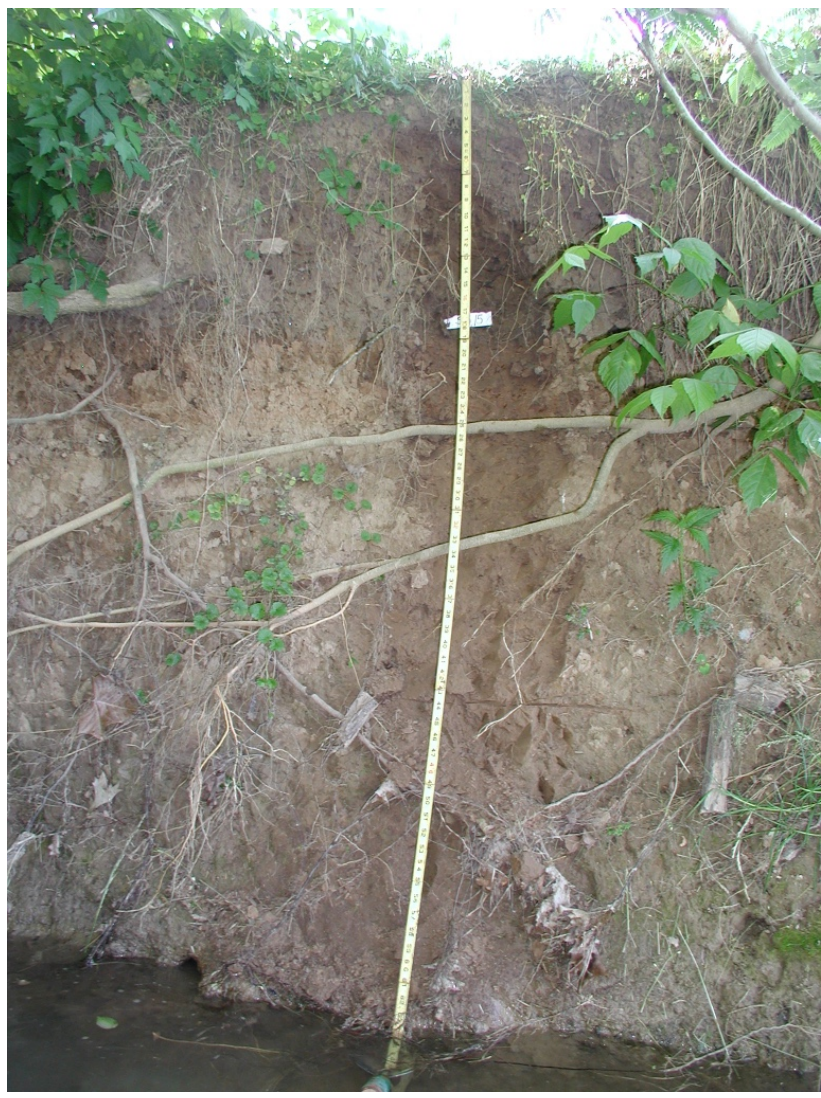




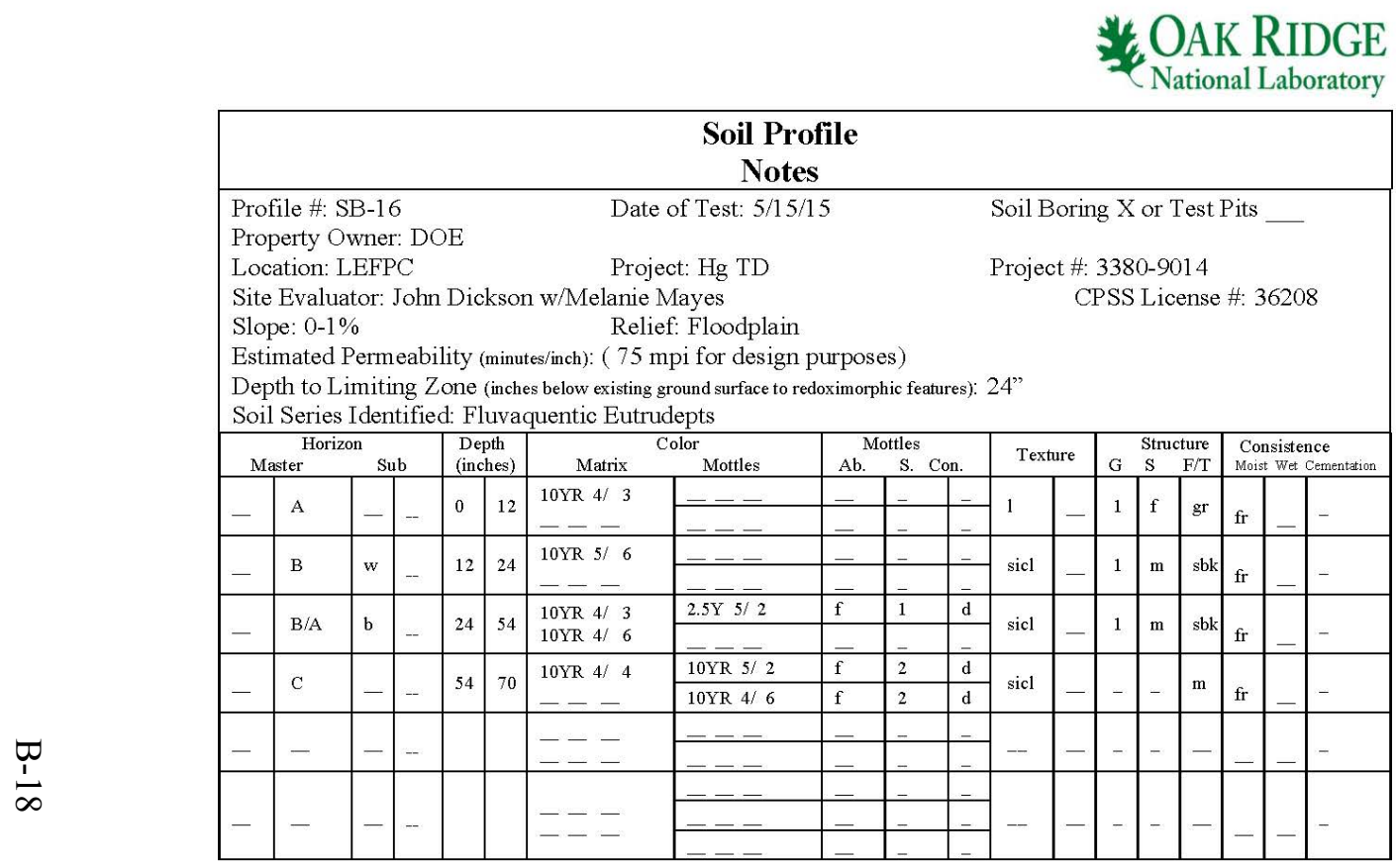

Comments:

GPS Coordinate: N: 36.00900 ; W: $-84.27162 \pm 18$

At 32-54" dark thin layer, 10YR 4/3, appears to be buried soils.

SB located in the vicinity of over-head electric poles and, the area appears to be slightly disturbed. Opposite bank located on a high landscape position.

Depth to water surface in creek $\sim 70^{\prime \prime}$ from top of bank.

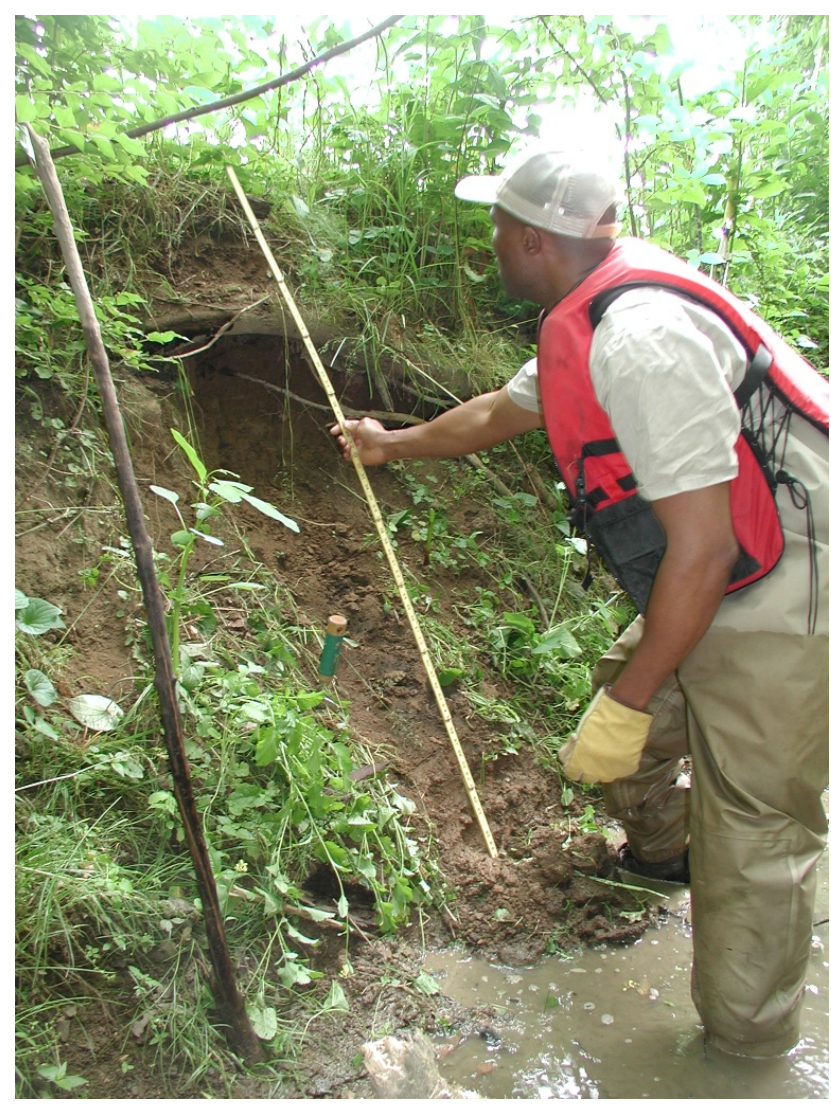




\section{OAK RIDGE}

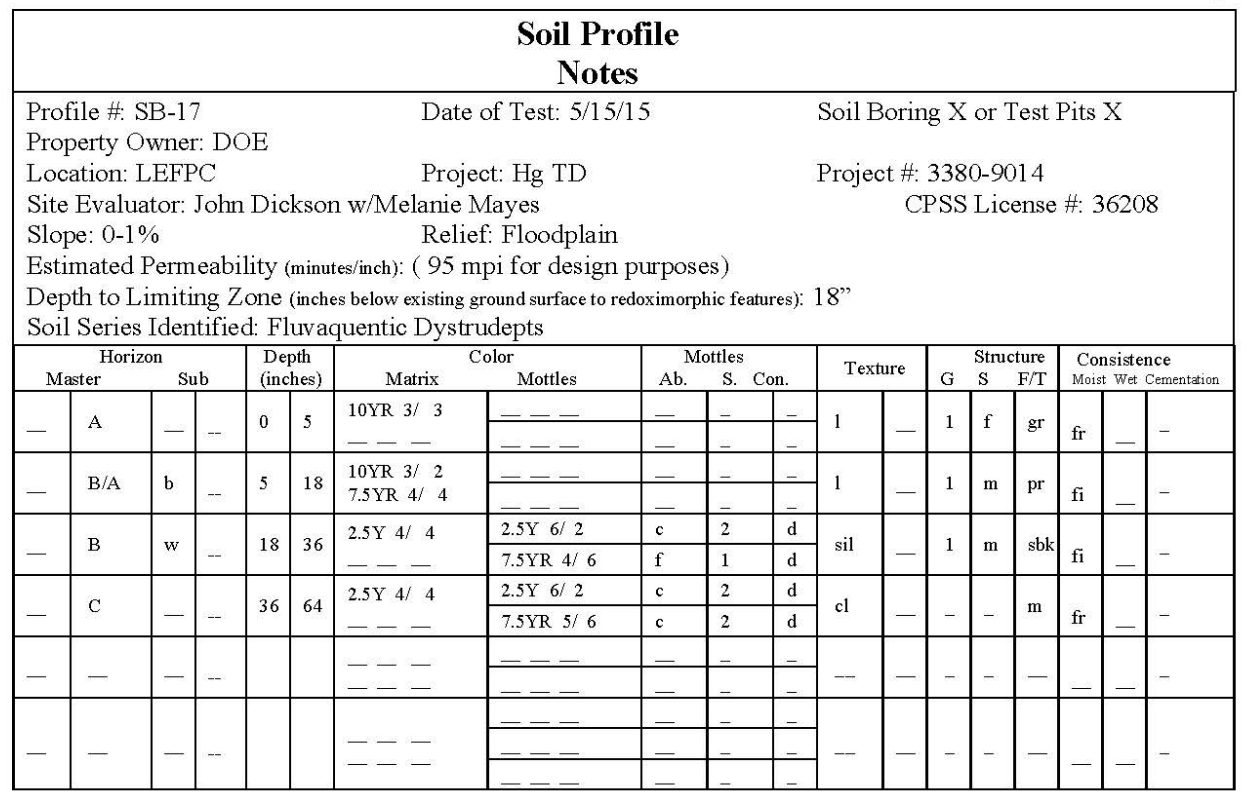

Comments:

GPS Coordinate: N: $36.00990 ; \mathrm{W}:-84.27386$

5-18" appears to be "Black layer", 10YR 3/3(2). Require additional investigation to confirm.

Depth to water surface in creek 64" from top of bank.

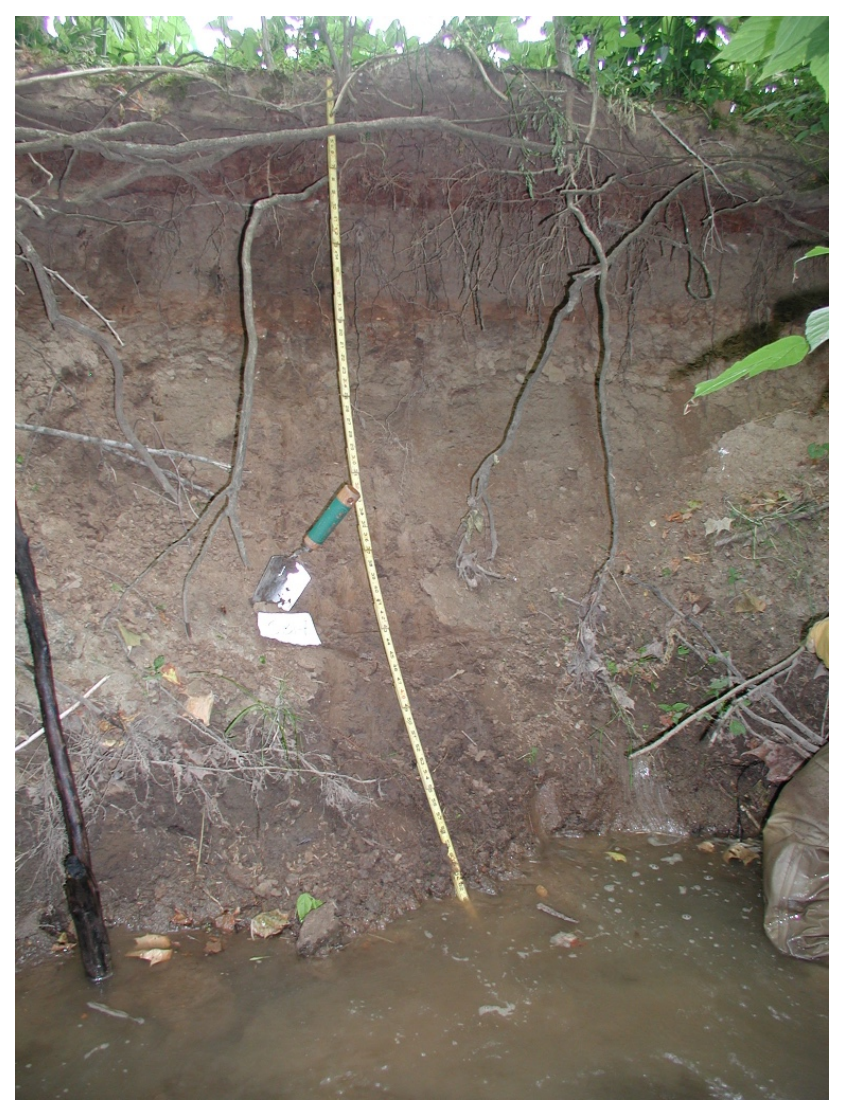

Site Evaluator's Signature: 


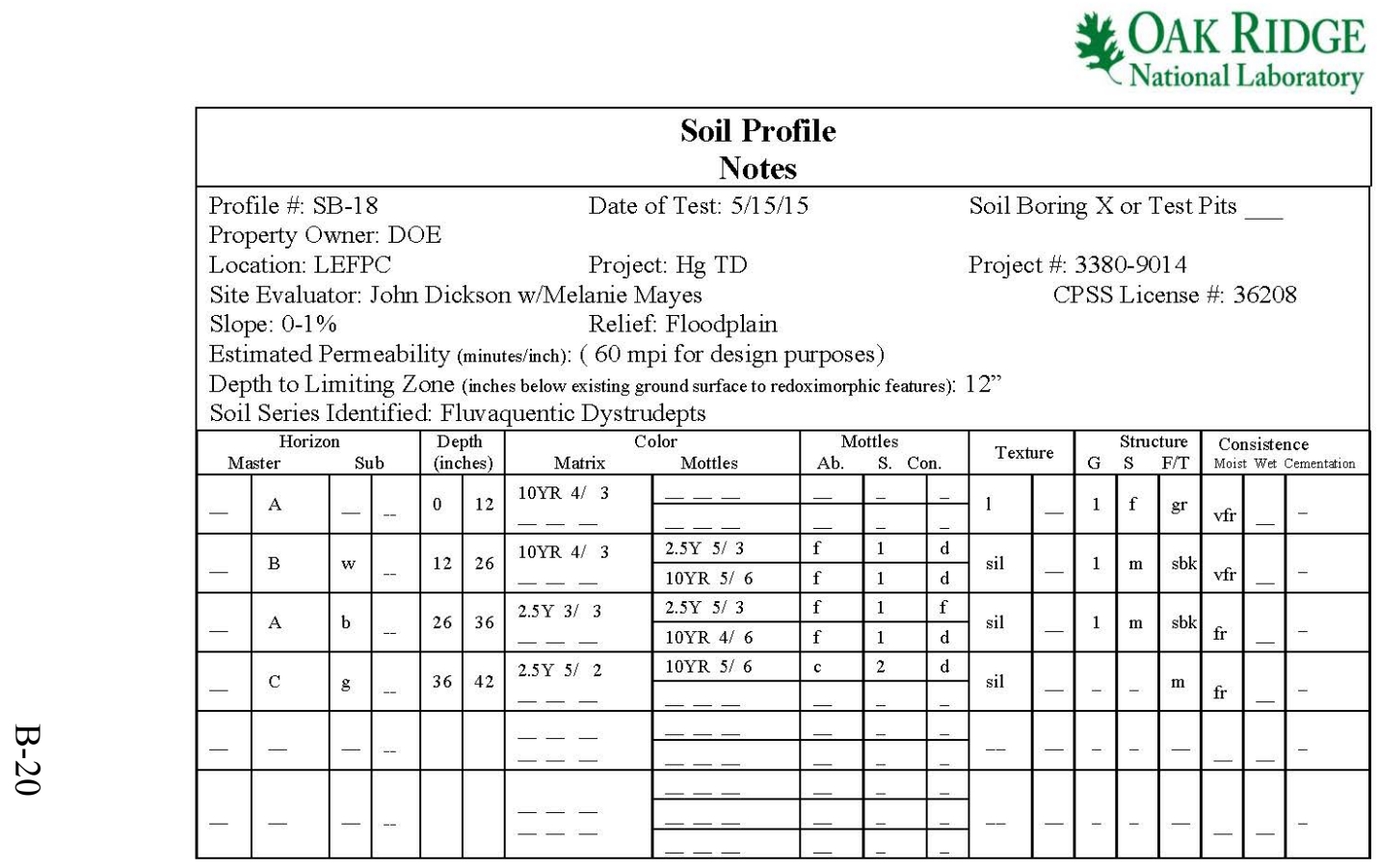

Comments:

GPS Coordinate: N: $36.00948 ; \mathrm{W}:-84.27637$

Depth to water surface in creek $\sim 42$ " from top of bank.

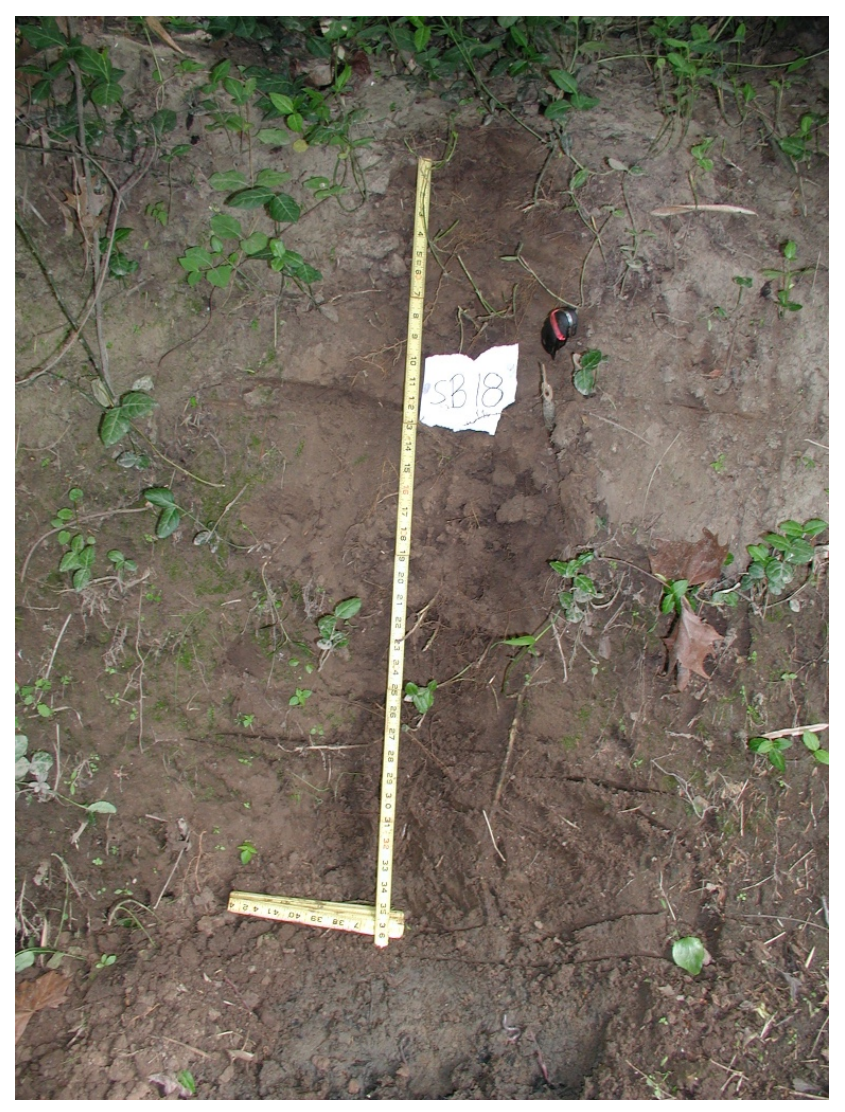




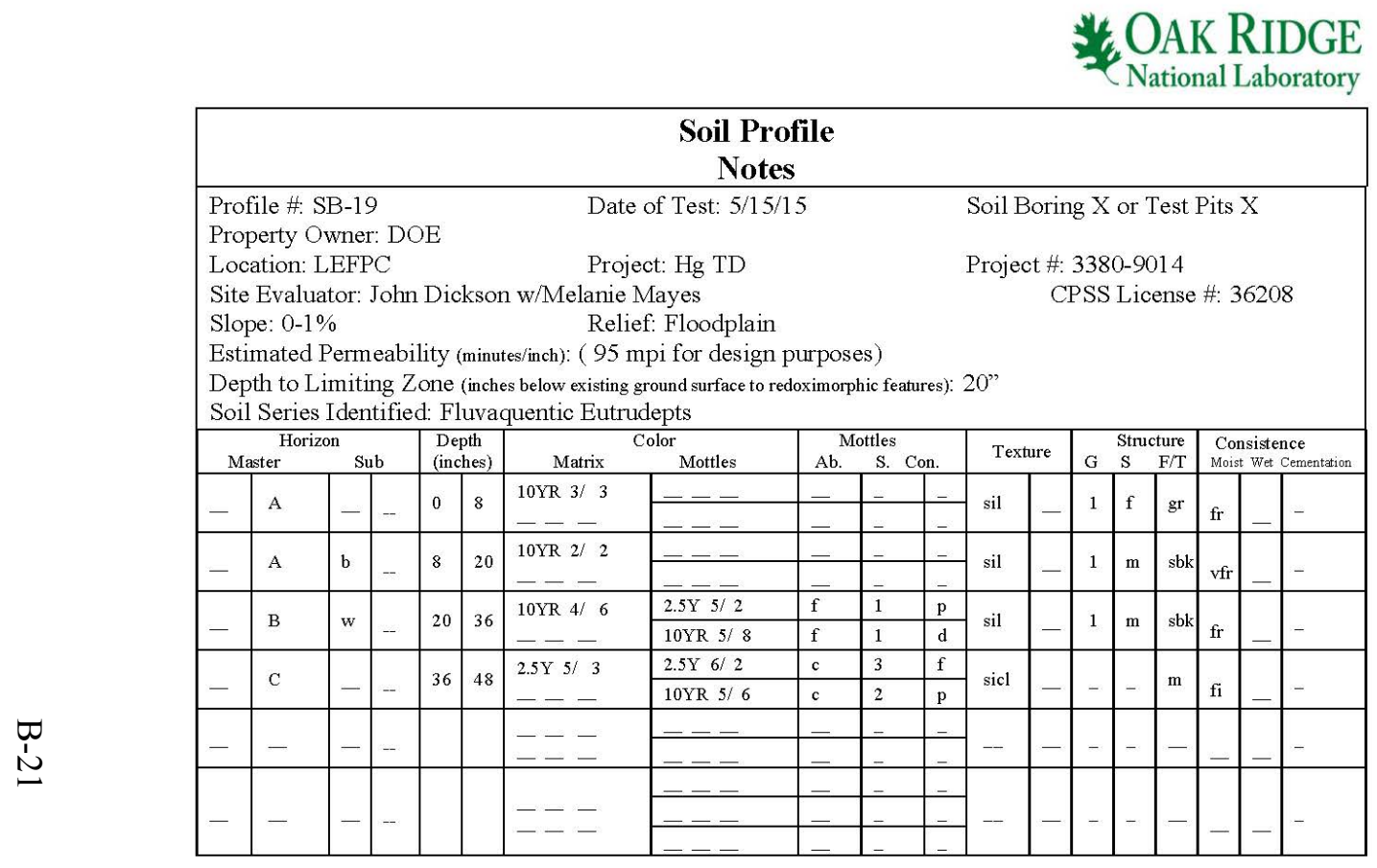

Comments:

GPS Coordinate: N: 36.00949; W: -84.27697

At 8-20" Black layer, 10YR 2/2 observed

Depth to water surface in creek $\sim 48$ " from top of bank.

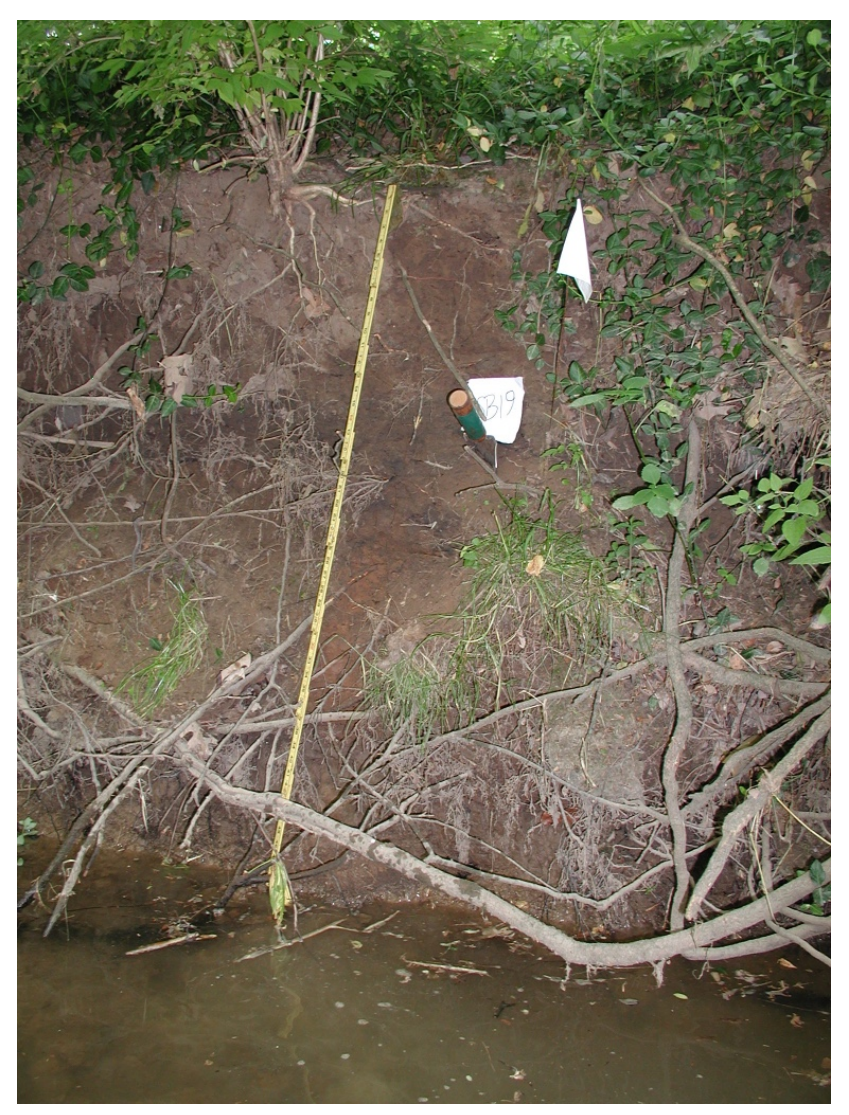




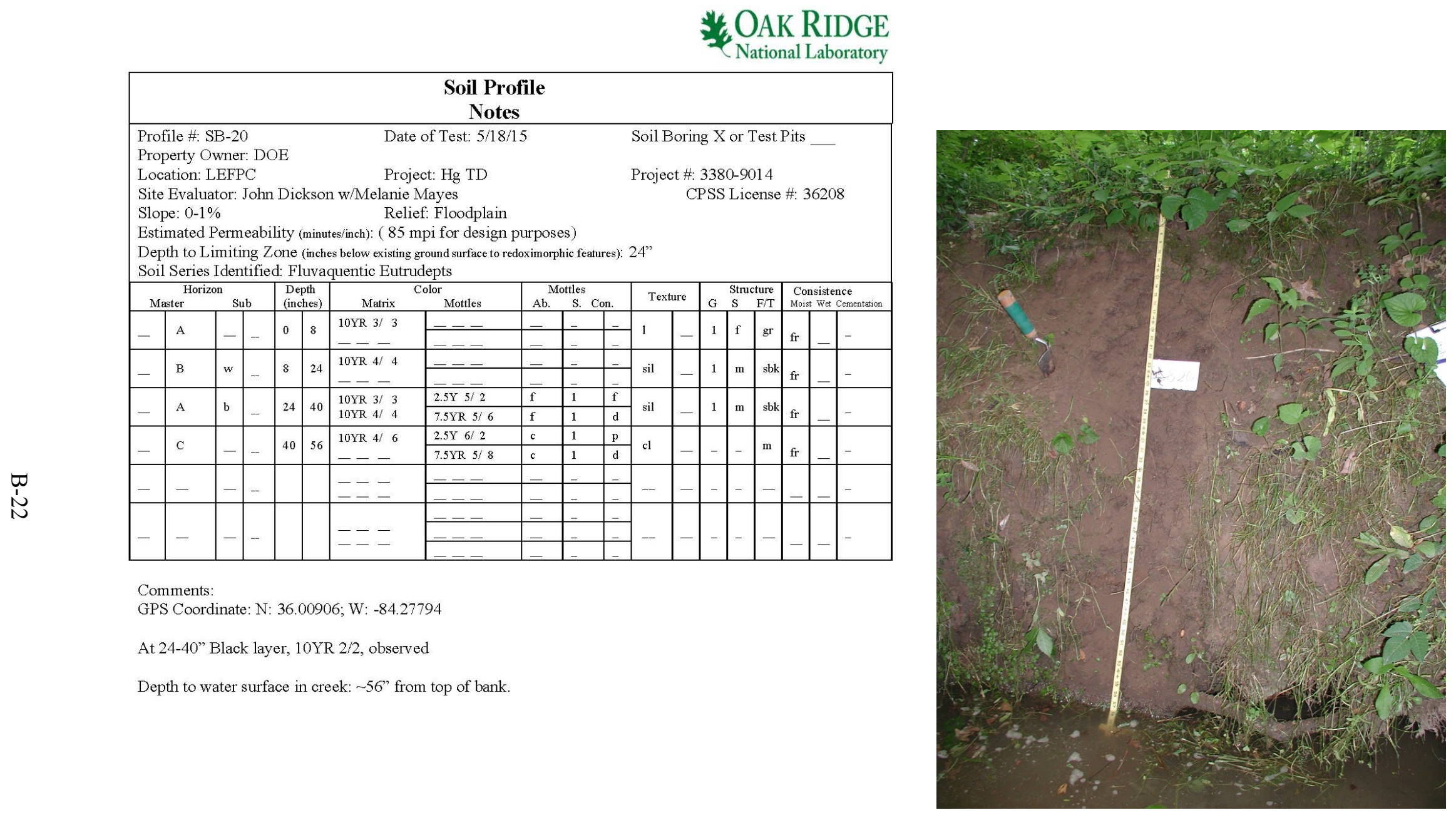

Site Evaluator's Signature 


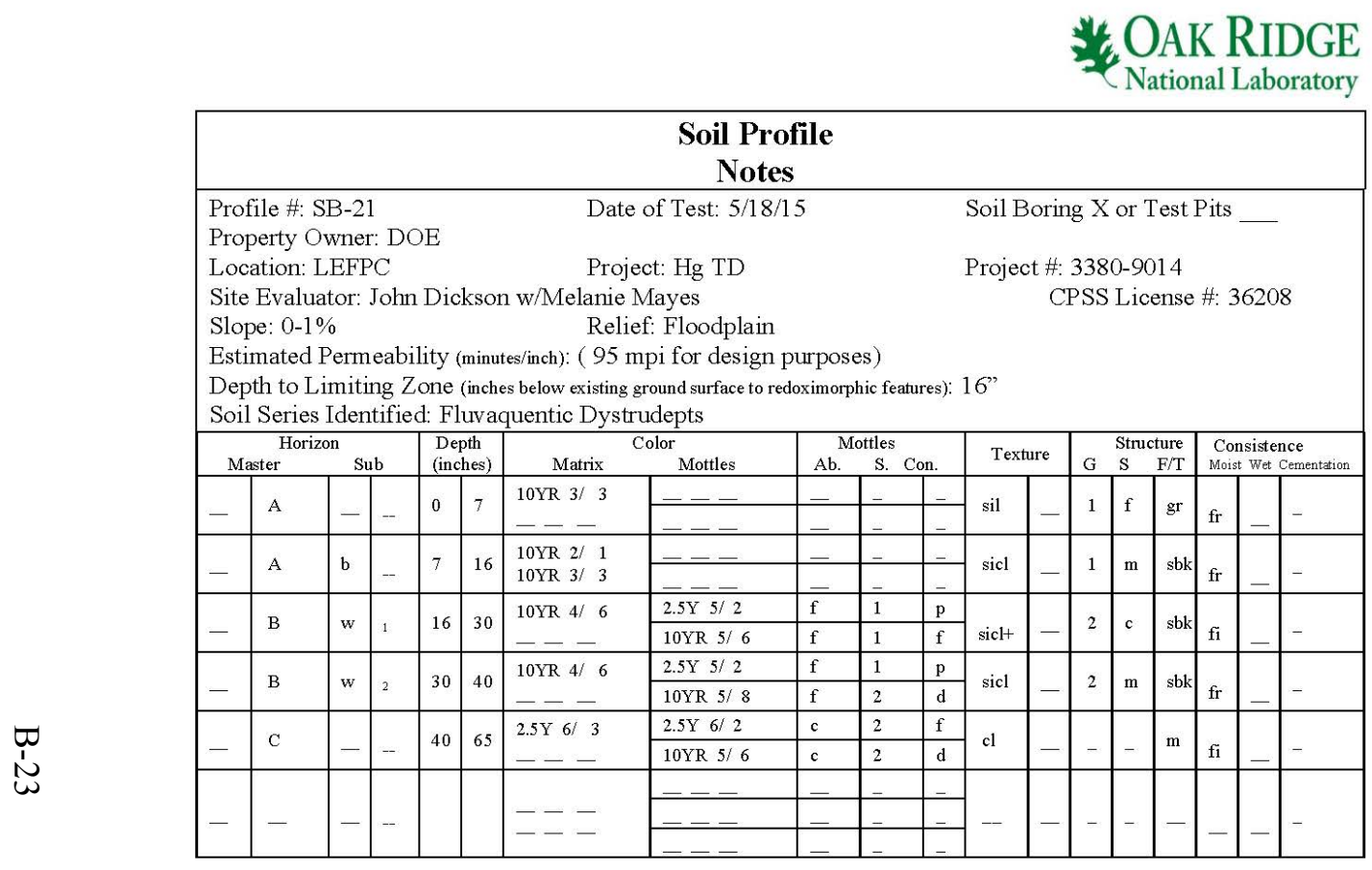

Comments

GPS Coordinate: N: 36.00897 ; W: $-84.27888 \pm 7.5$

At 7-16" black layer, 10YR 2/2, observed

Depth to water surface in creek: $\sim 65$ " from top of bank.

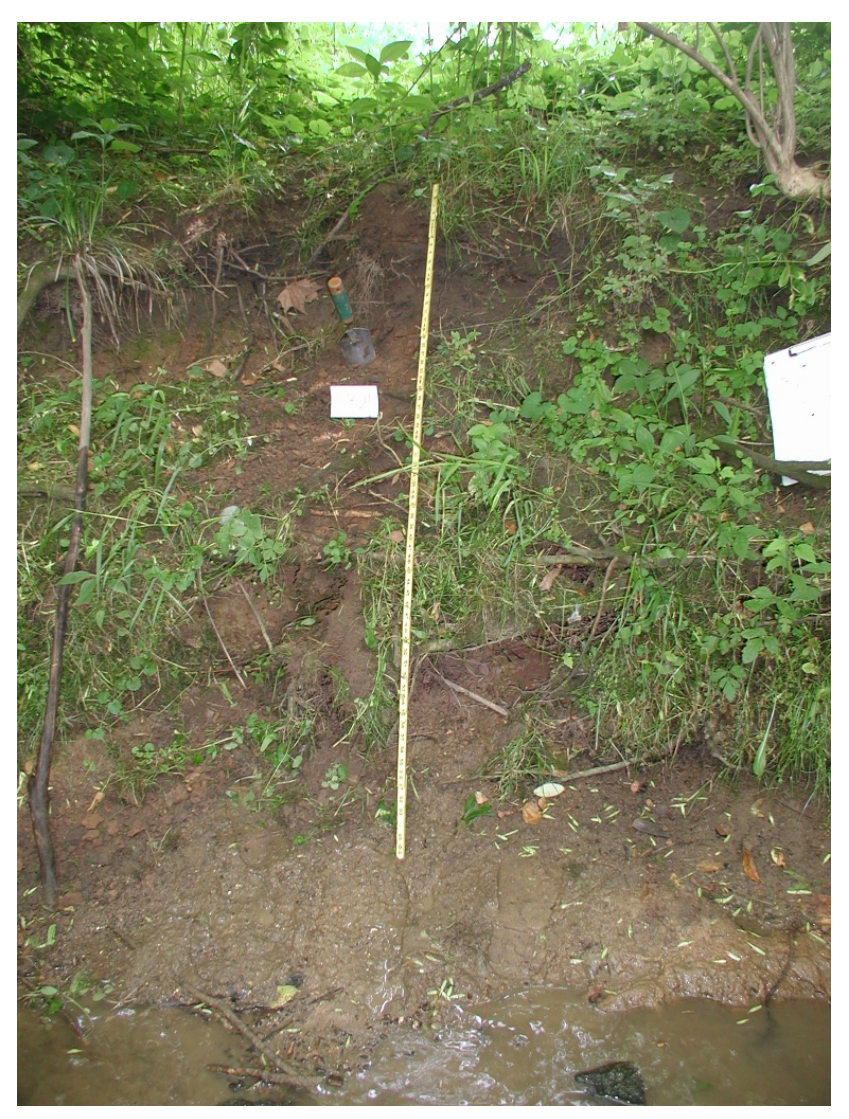




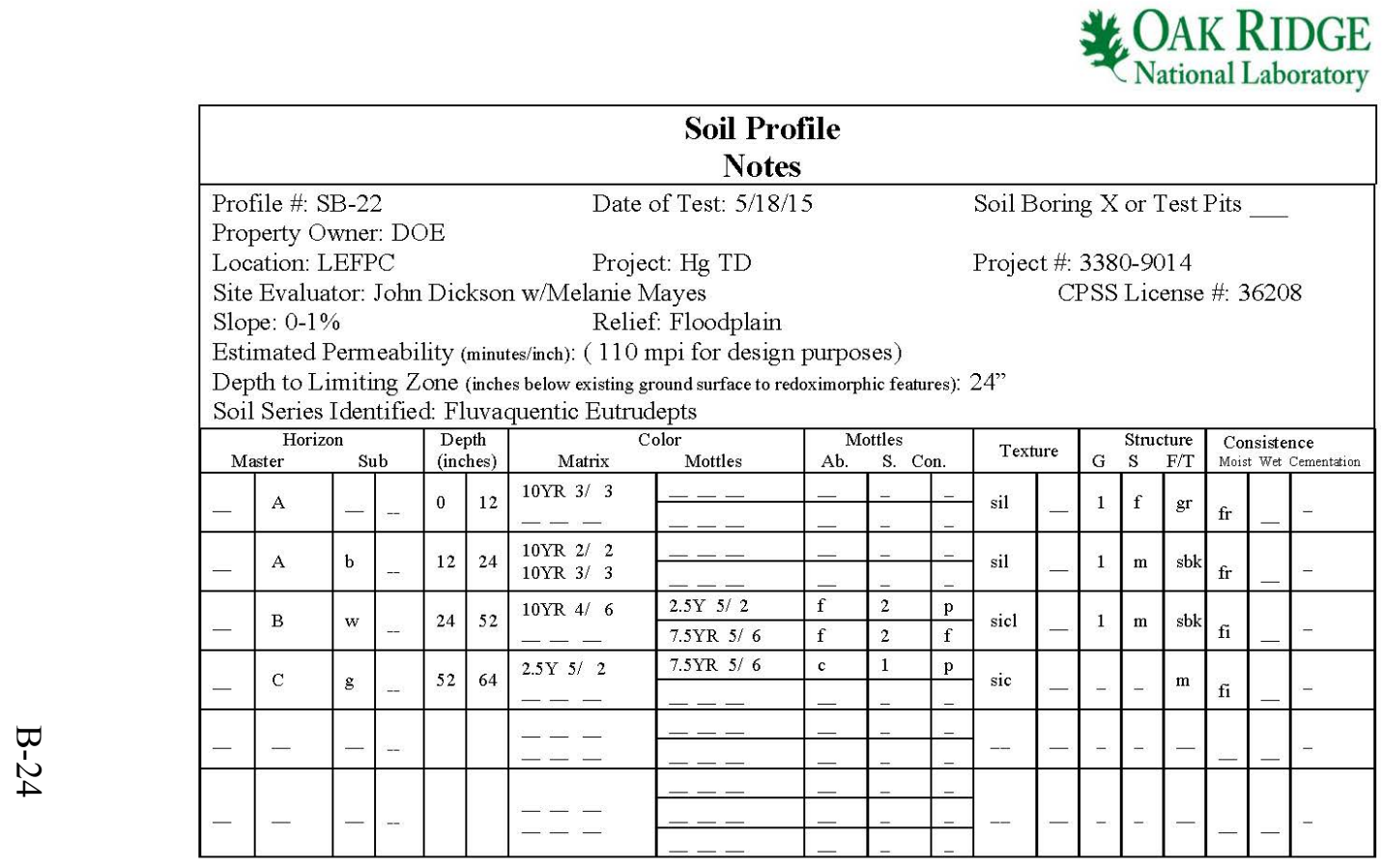

Comments :

GPS Coordinate: N: $36.00838 ; \mathrm{W}:-84.28075 \pm 11.5$

At 12-24" black layer, 10YR 2/2, observed

Depth to water surface in creek: 64 " from top of bank.

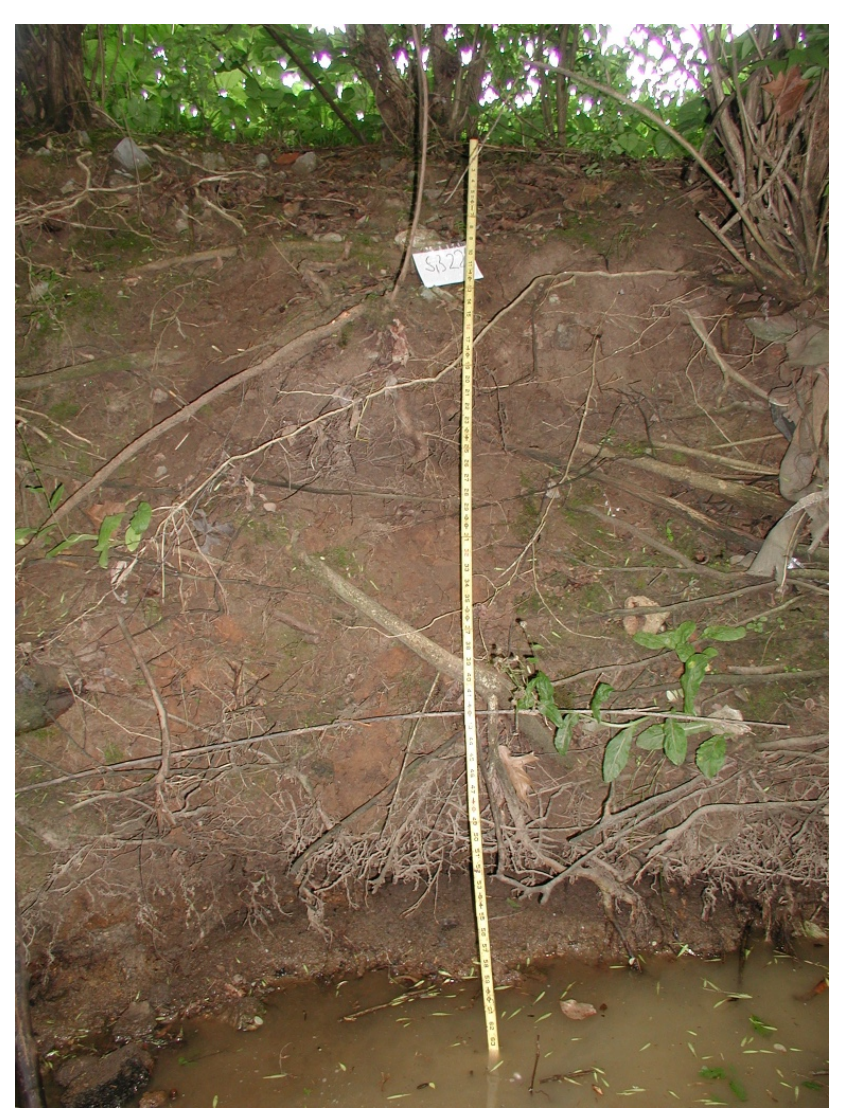




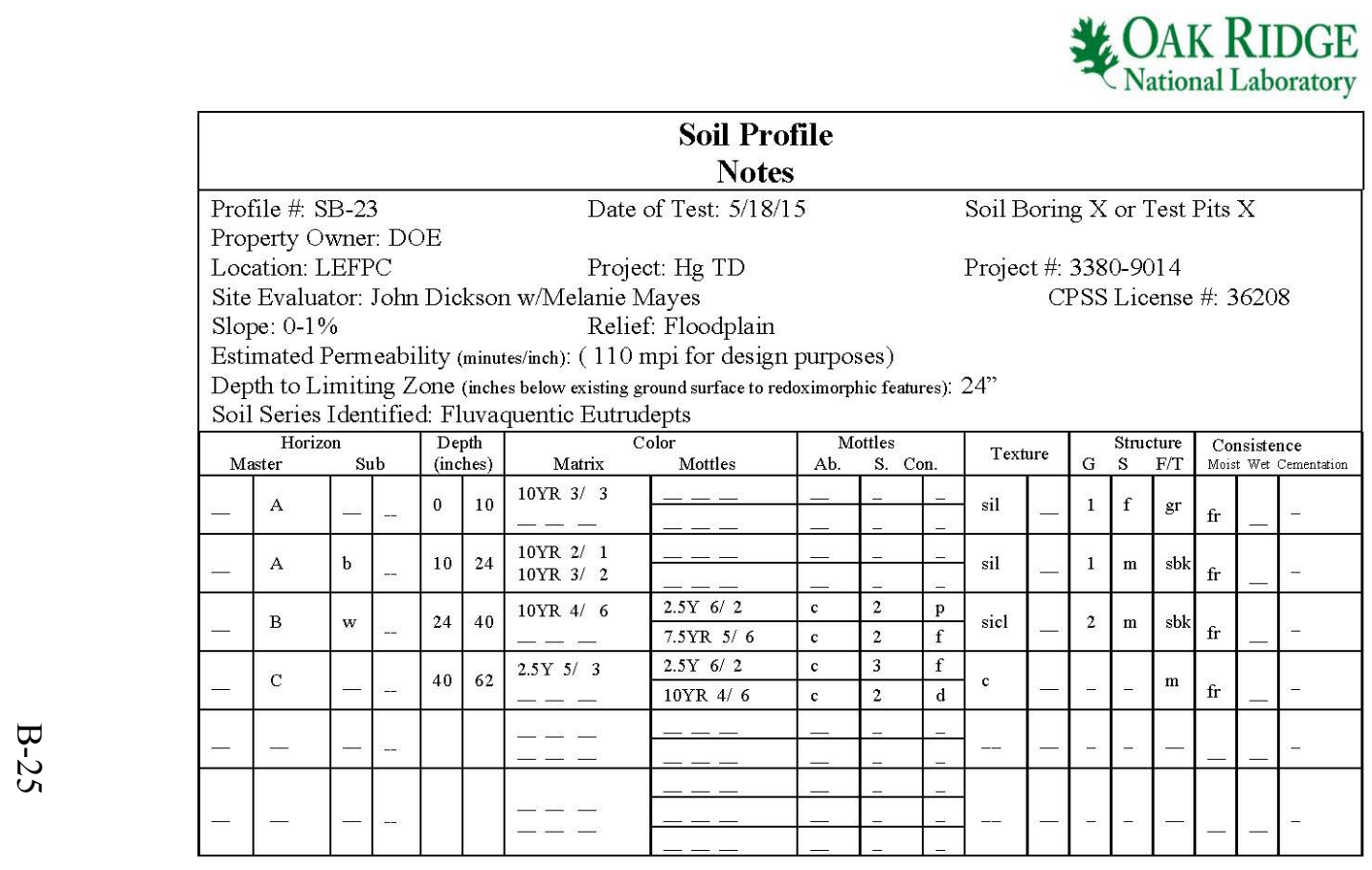

Comments:

GPS Coordinate: N: $36.00563 ; \mathrm{W}:-84.28060$

At 10-24" black layer, 10YR 2/2, observed

Collected bulk density sample within black layer.

Depth to water surface in creek: $\sim 62$ " from top of bank.

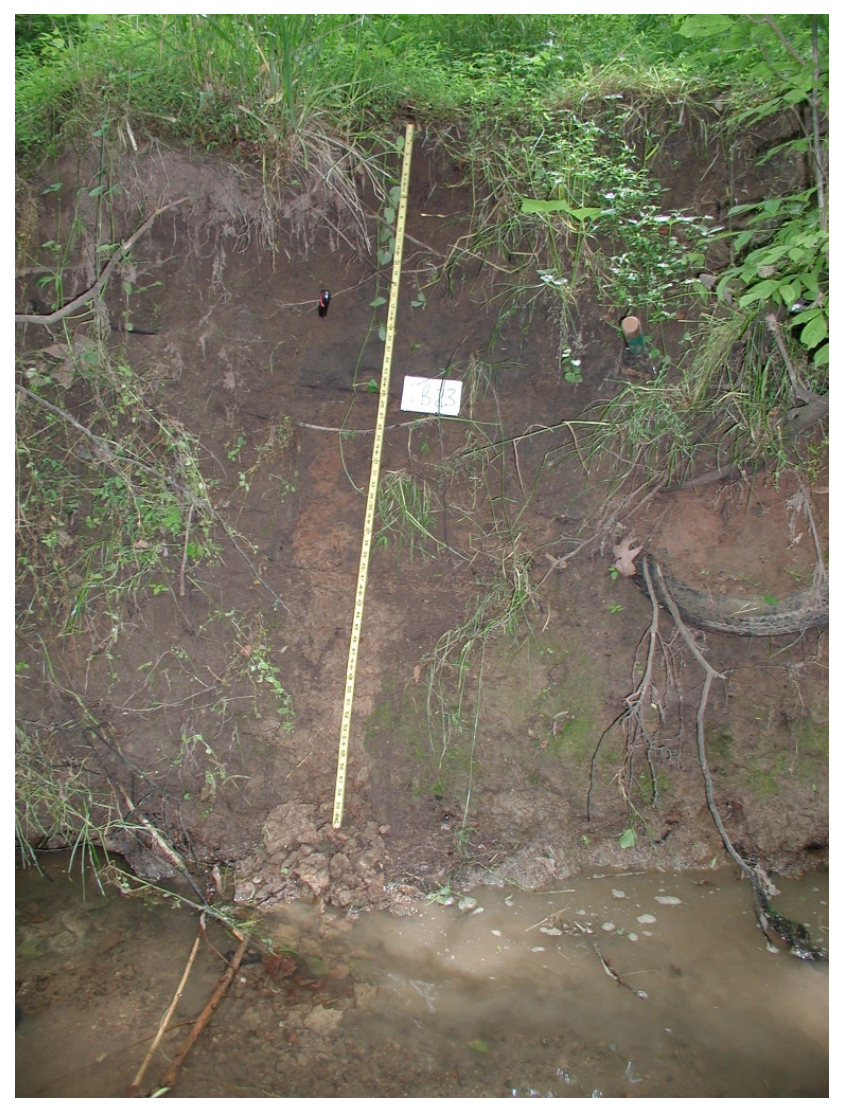




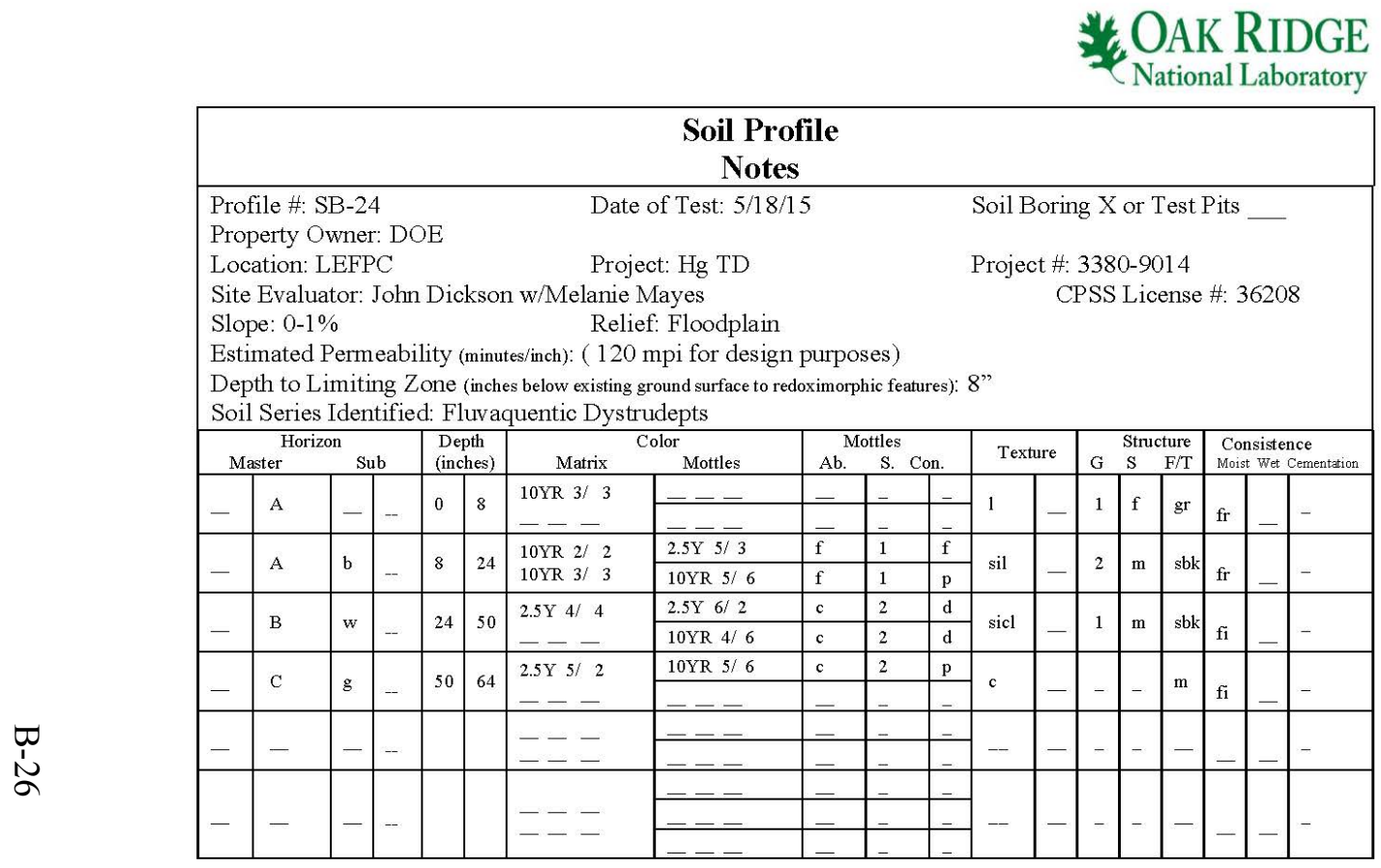

Comments:

GPS Coordinate: N: $36.00438 ; \mathrm{W}:-84.28246$

At 8-24" black layer, $10 \mathrm{YR} 2 / 2$, observed

At $25-50 "$ gravels/cobbles $(\sim 5 \%)$

Depth to water surface in creek: $\sim 64$ " from top of bank

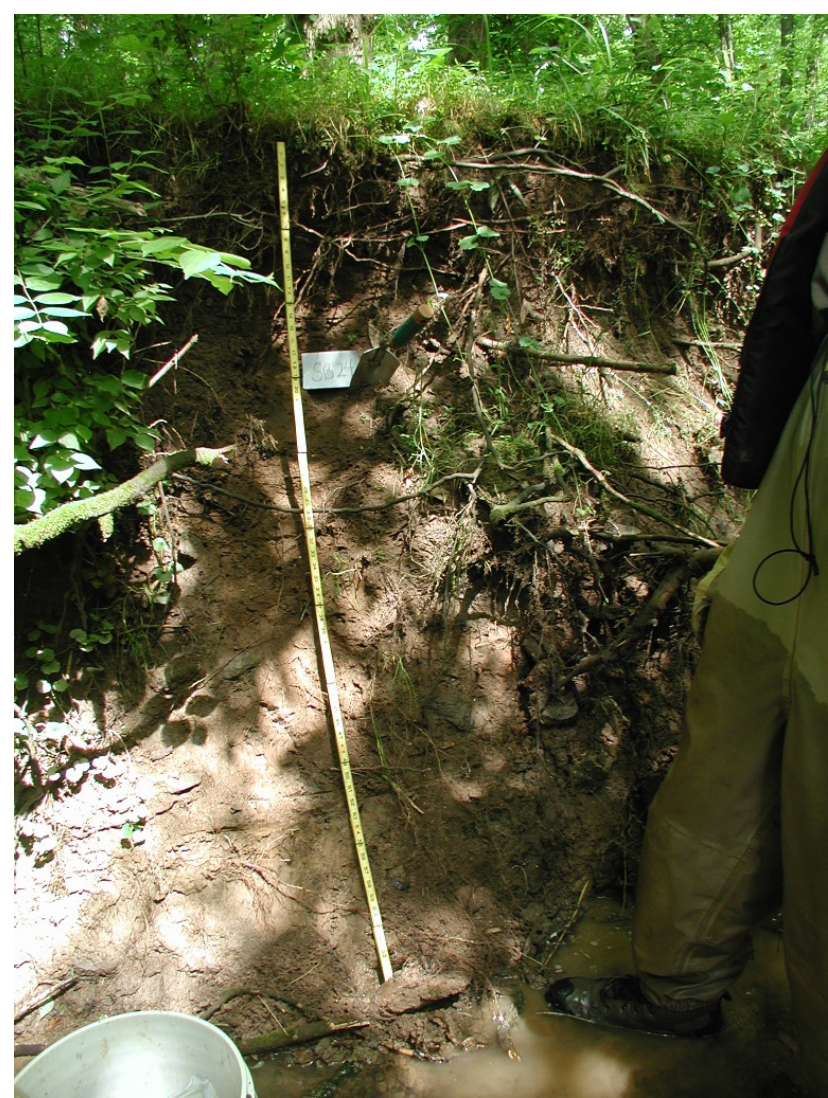




Soil Profile
Notes

Comments:

GPS Coordinate: N: 36.00334 ; W: $-84.28526 \pm 19.0^{\prime}$

At 8-20" black layer, 10 YR $2 / 2$, observed

From 16" many mottles

Depth to water surface in creek: 72 " from top of bank

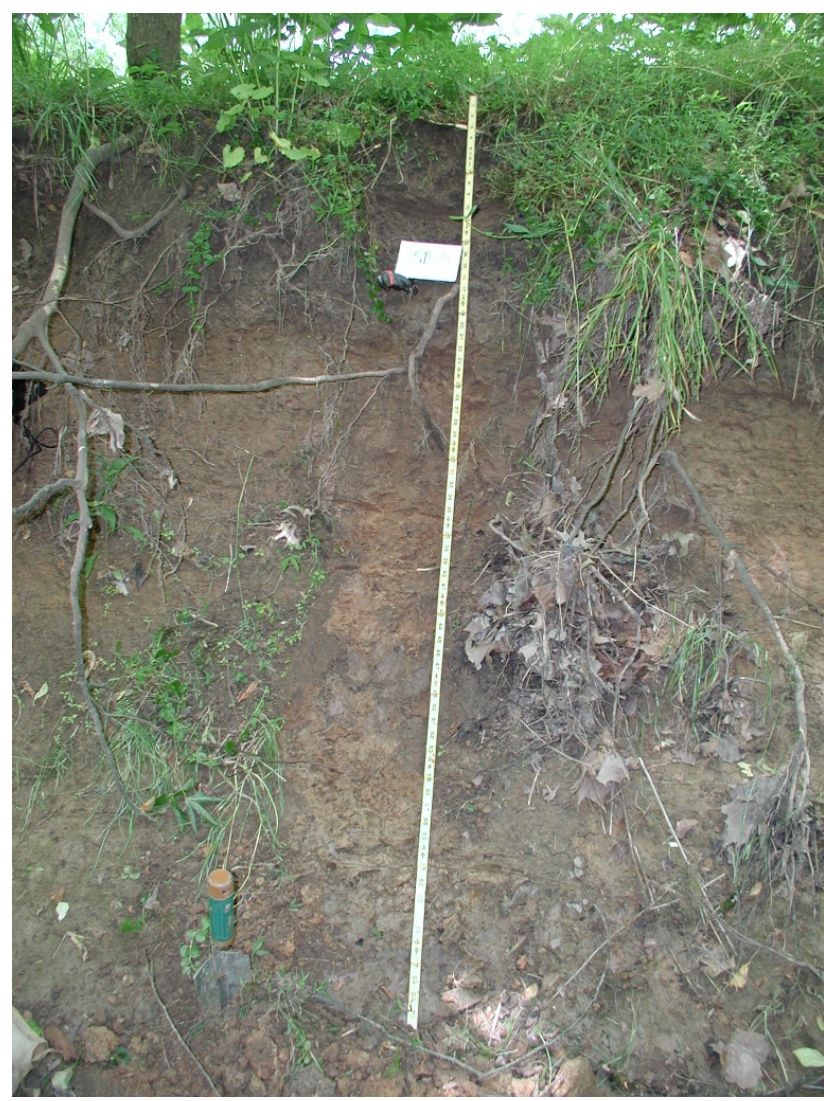




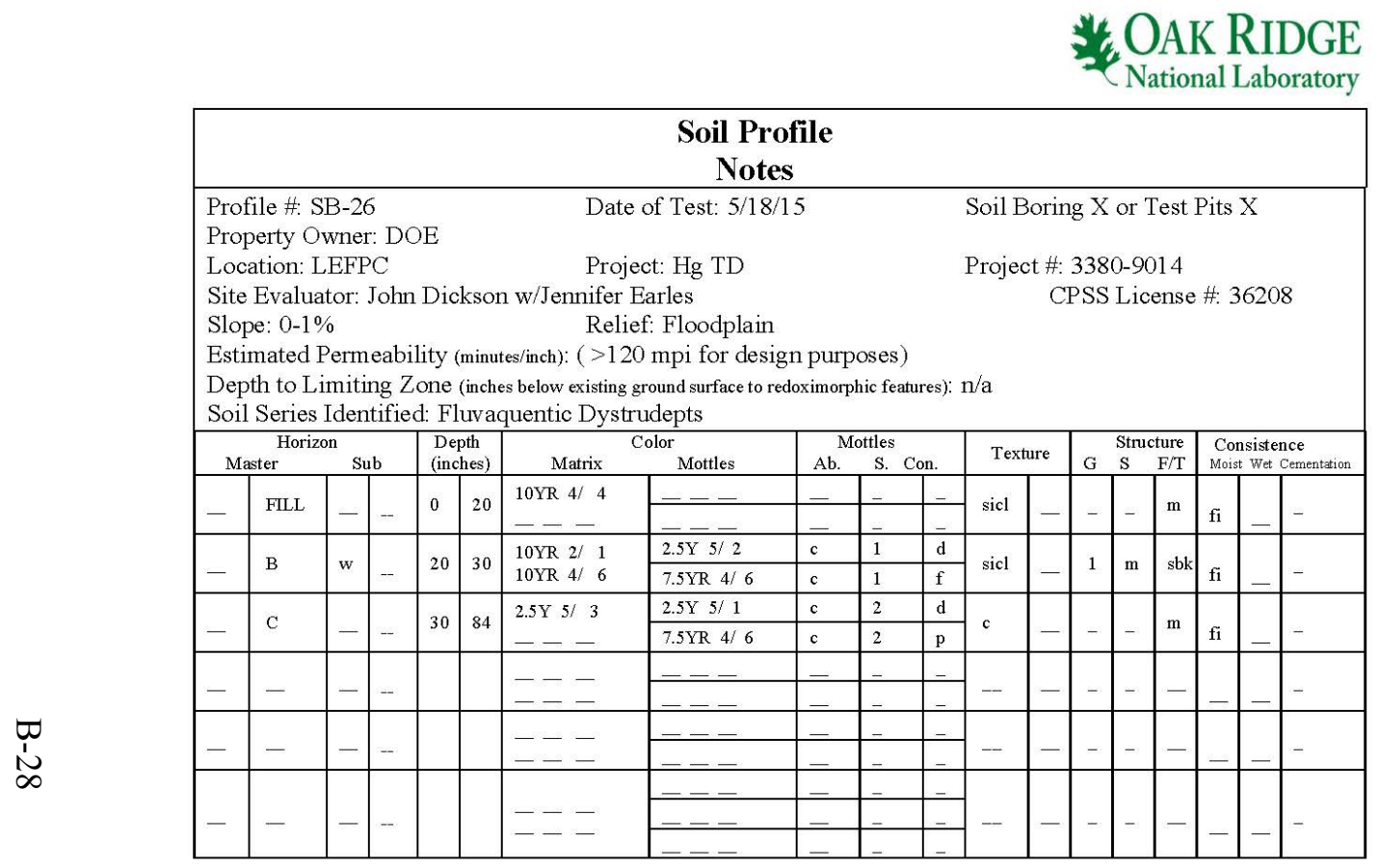

Comments:

GPS Coordinate: N: 36.00225 ; W: $-84.28868 \pm 10.5$,

At 20-30" many thin bands of black layer, 10YR 2/1

SB located within previously remediated area, $~ 25$ " from SB 6-5

Depth to water surface in creek: $\sim 84$ " from top of bank.

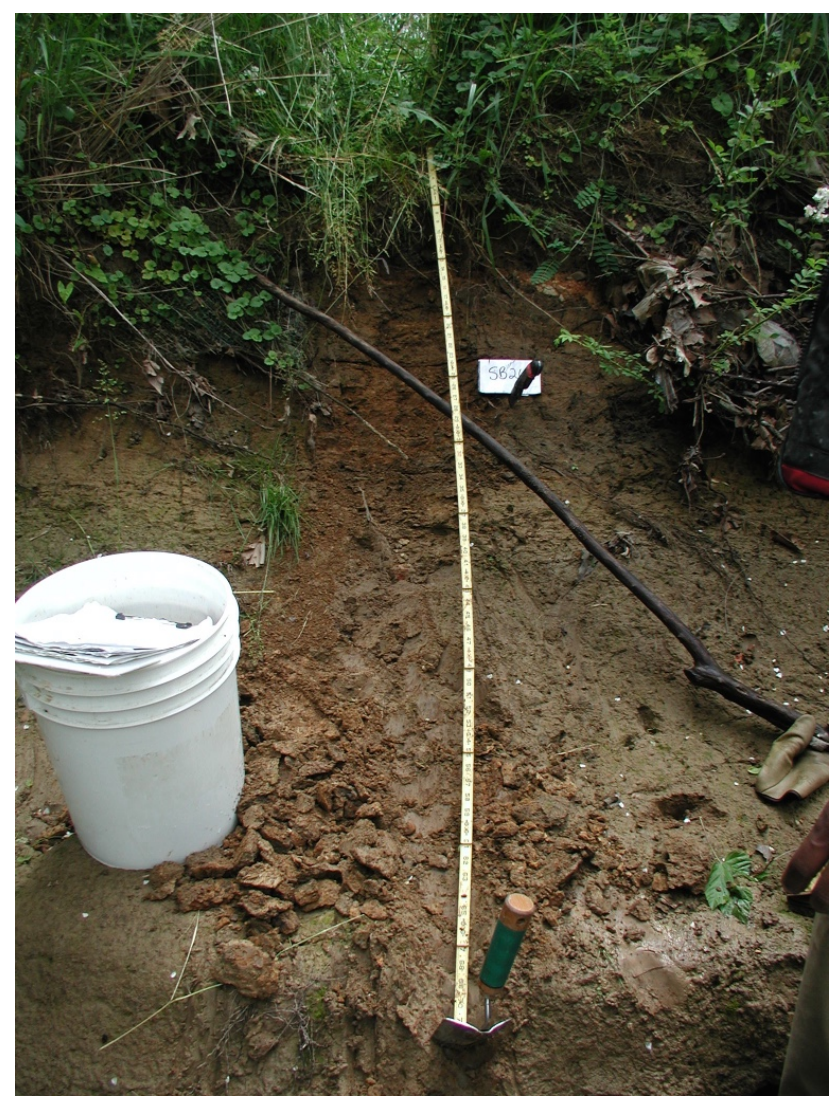




Soil Profile
Notes

Comments:

GPS Coordinate: N: 35.99974 ; W: $-84.29270 \pm 16$

6-20" appears to be a black layer, 10 YR $2 / 2$

Inclusions of coarse sands at 20-32"

Depth to water surface in creek: $>72$ " from top of bank.

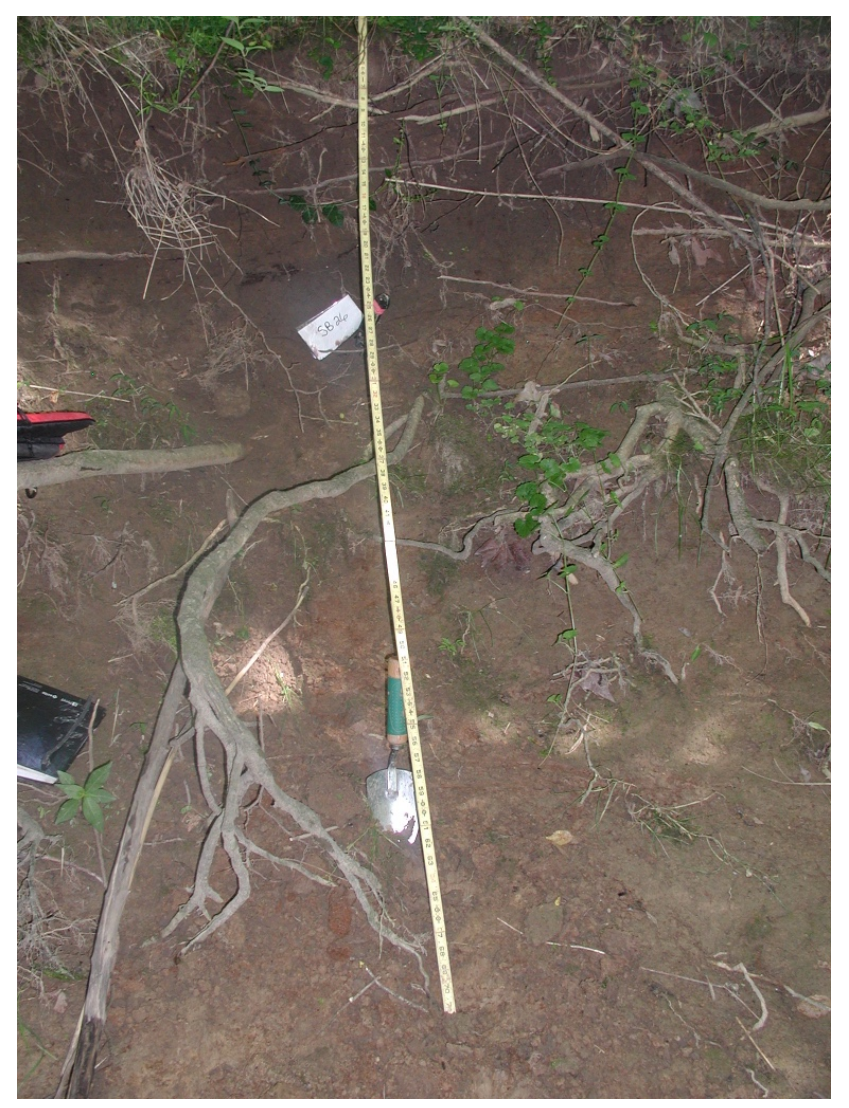




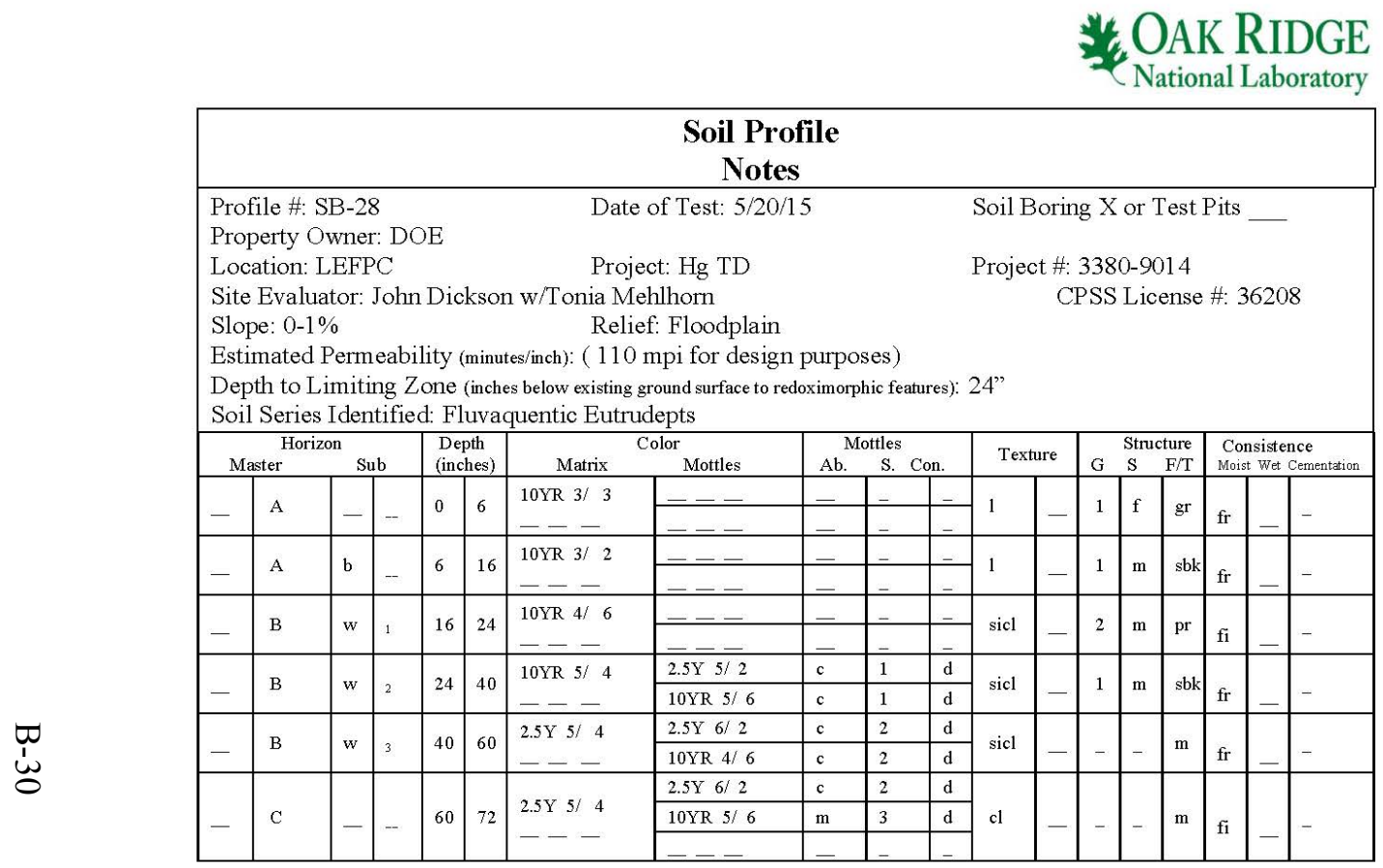

Comments:

GPS Coordinate: N: 35.99916 ; W: $-84.29367 \pm 10^{\prime}$

Depth to water surface in creek: $\sim 90^{\prime \prime}$ from top of bank.

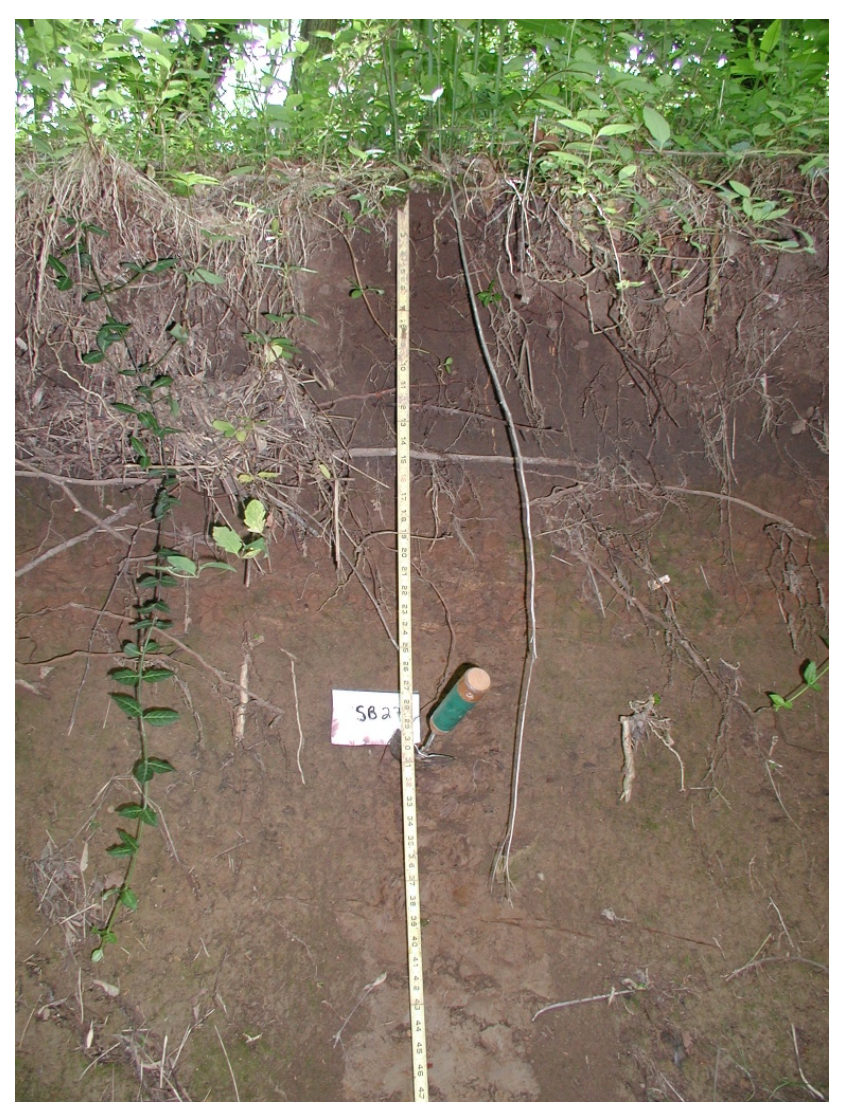

Site Evaluator's Signature 


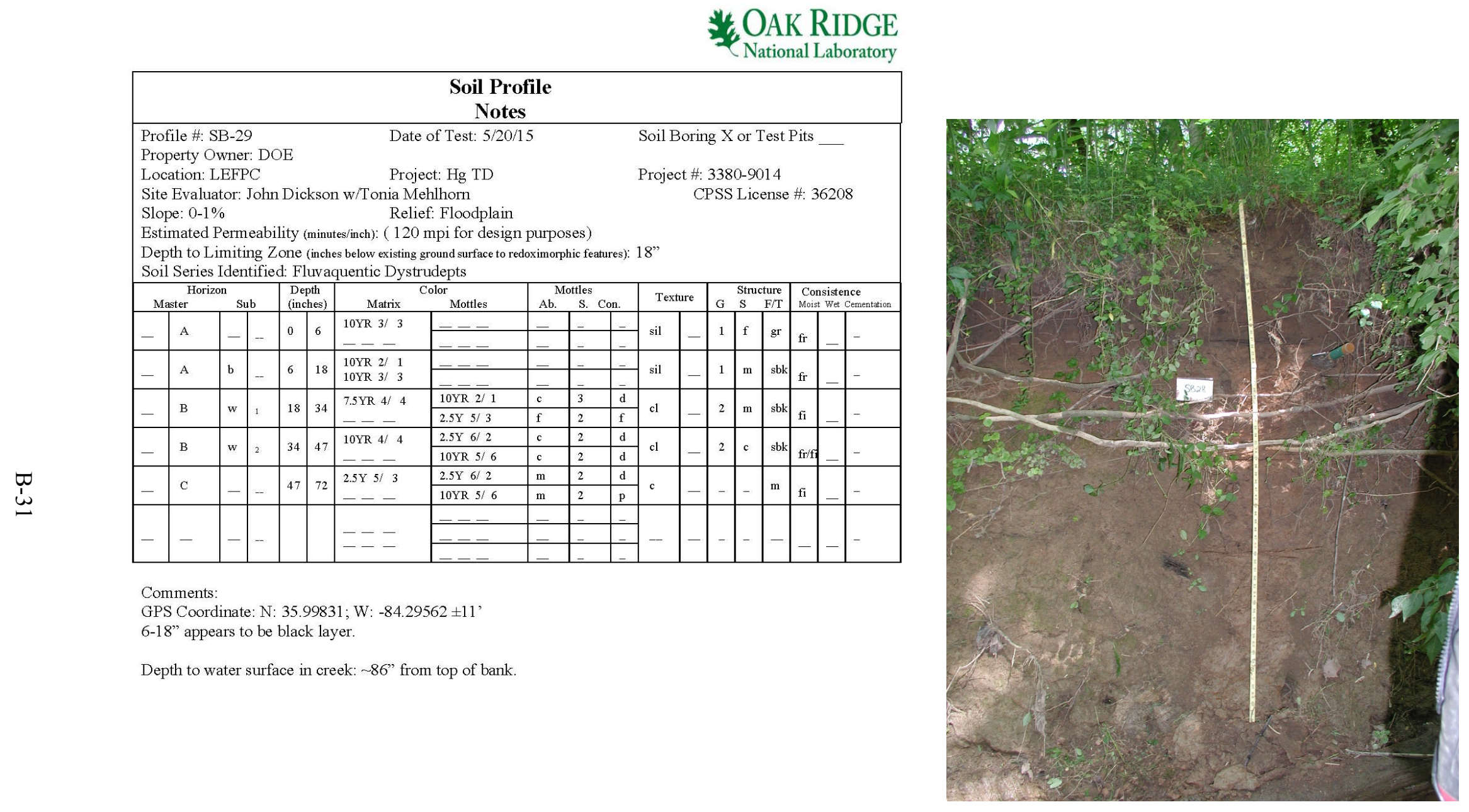

Site Evaluator's Signature: 


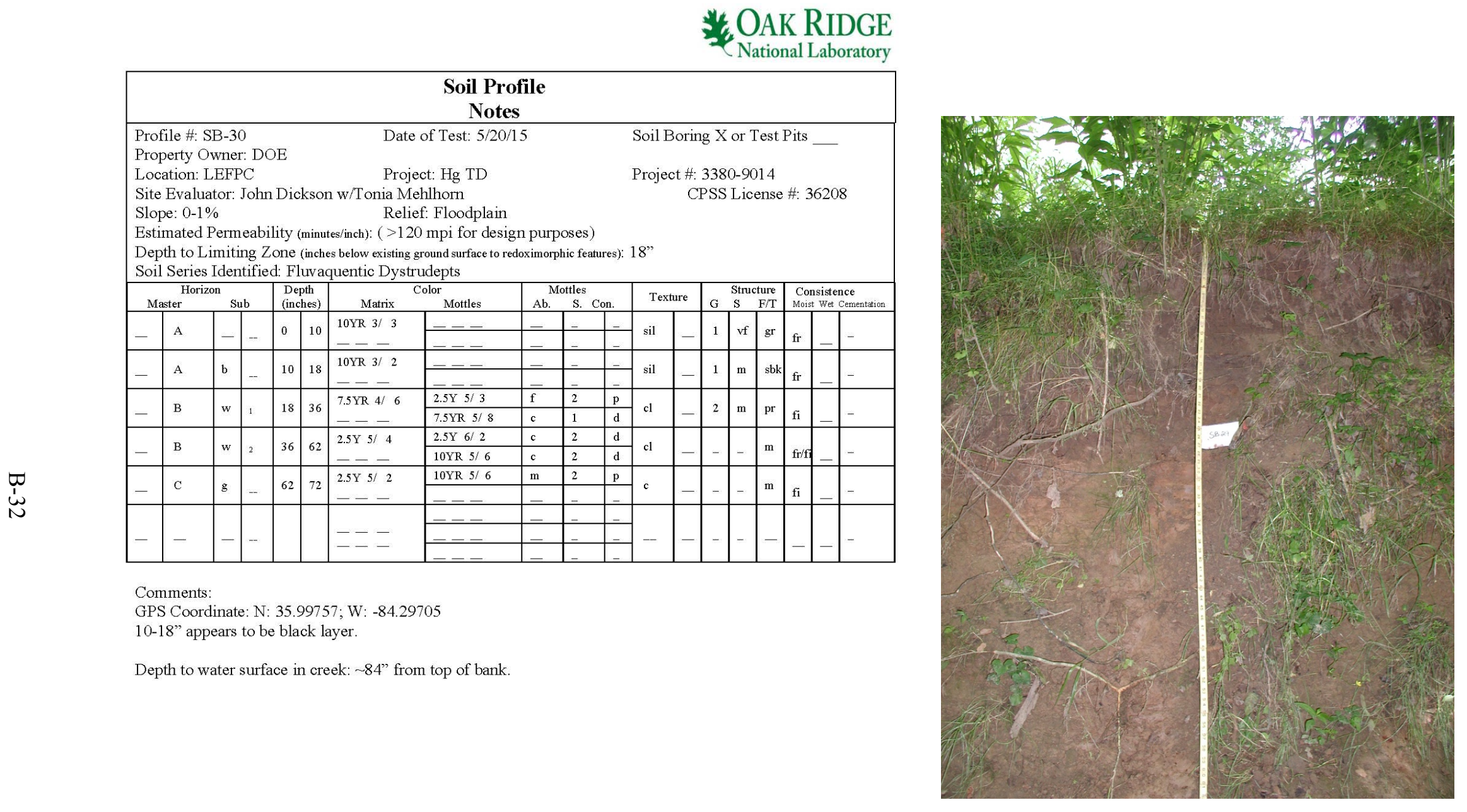




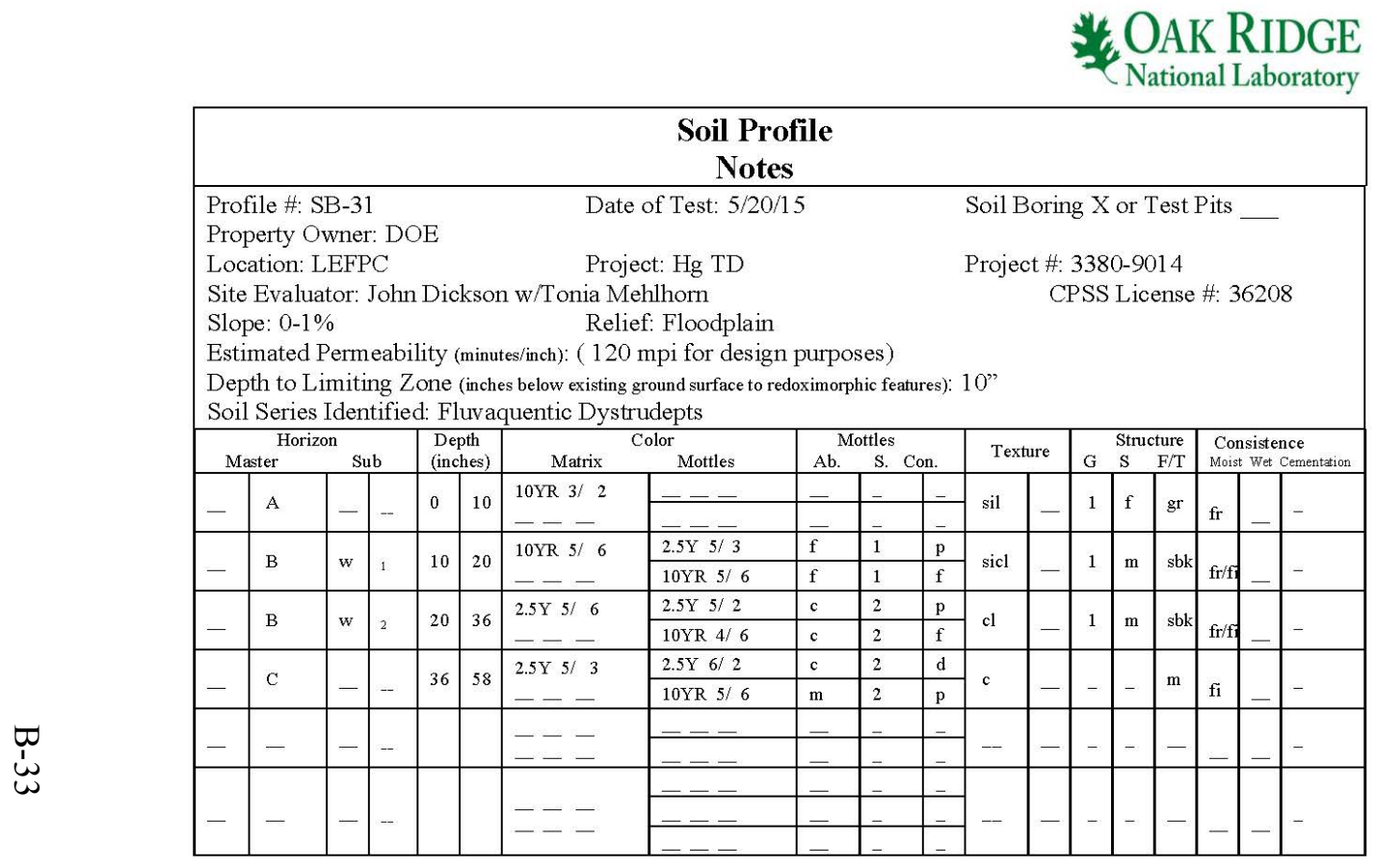

Comments:

GPS Coordinate: N: 35.99937 ; W: $-84.29831 \pm 20^{\prime}$

No black layer observed

Depth to water surface in creek: $\sim 58$ " from top of bank.

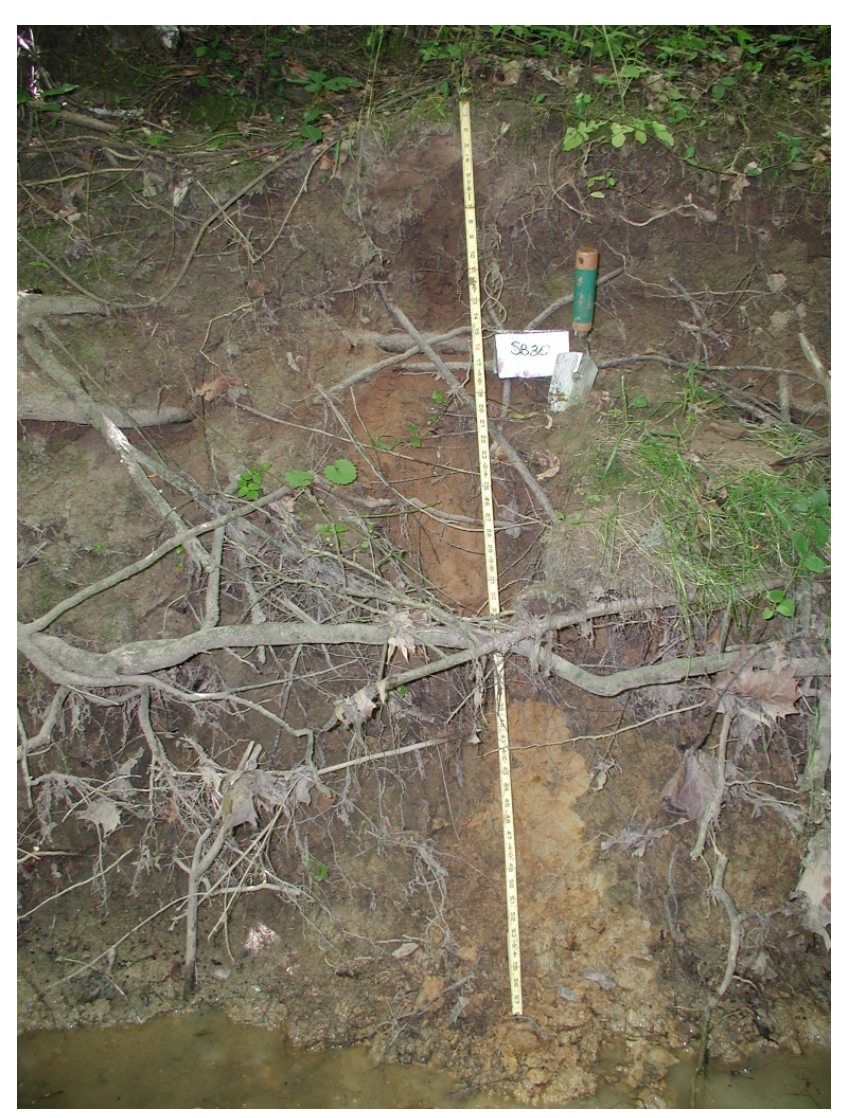




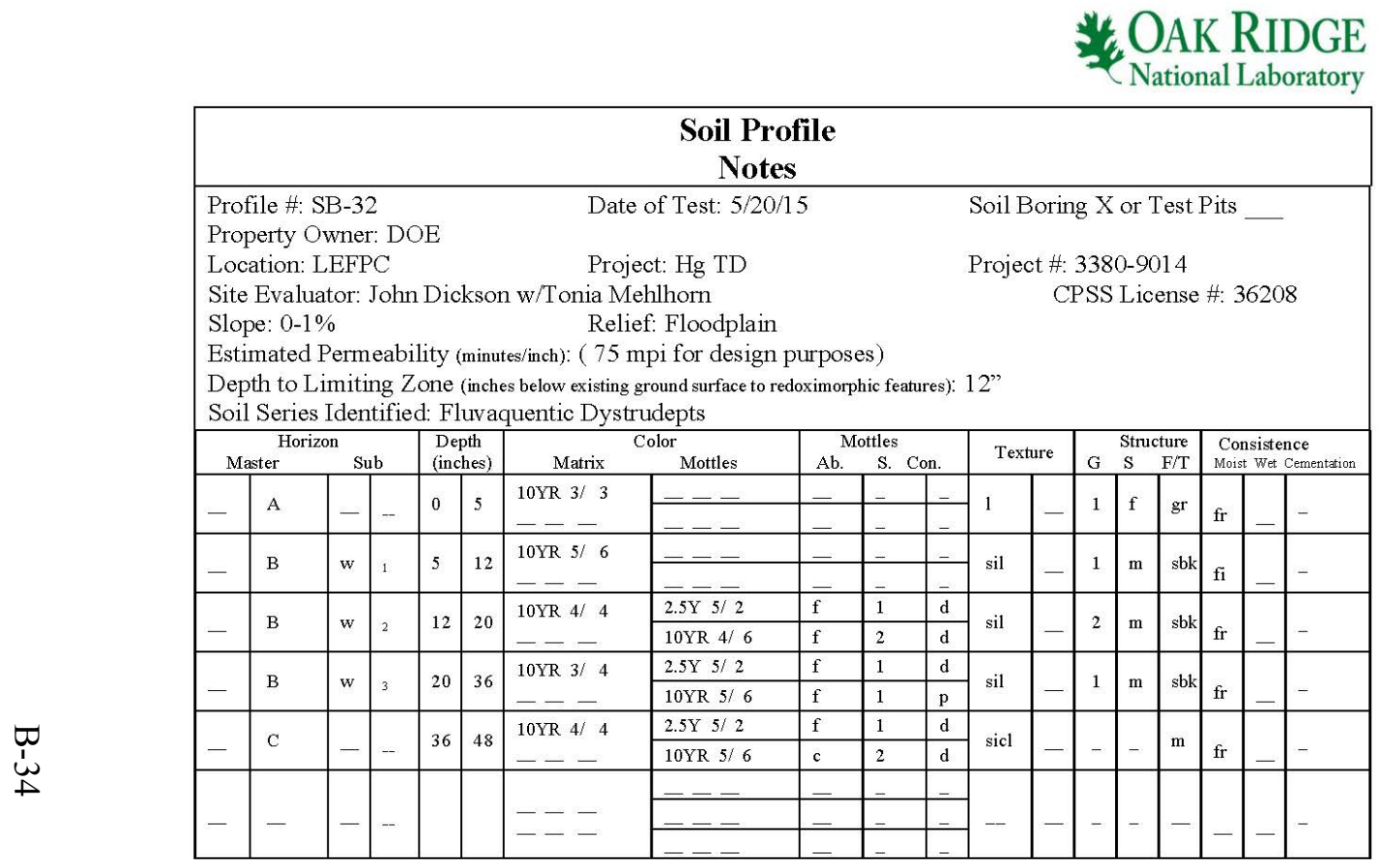

Comments:

GPS Coordinate: N: $35.99871 ; \mathrm{W}:-84.30052$

At 12-36" thin lenses of 10YR 2/1 observed

Below 48 " massive and firm clay, $2.5 \mathrm{Y} 5 / 3$ with many redoximorphic features

Depth to water surface in creek: $\sim 54$ " from top of bank.

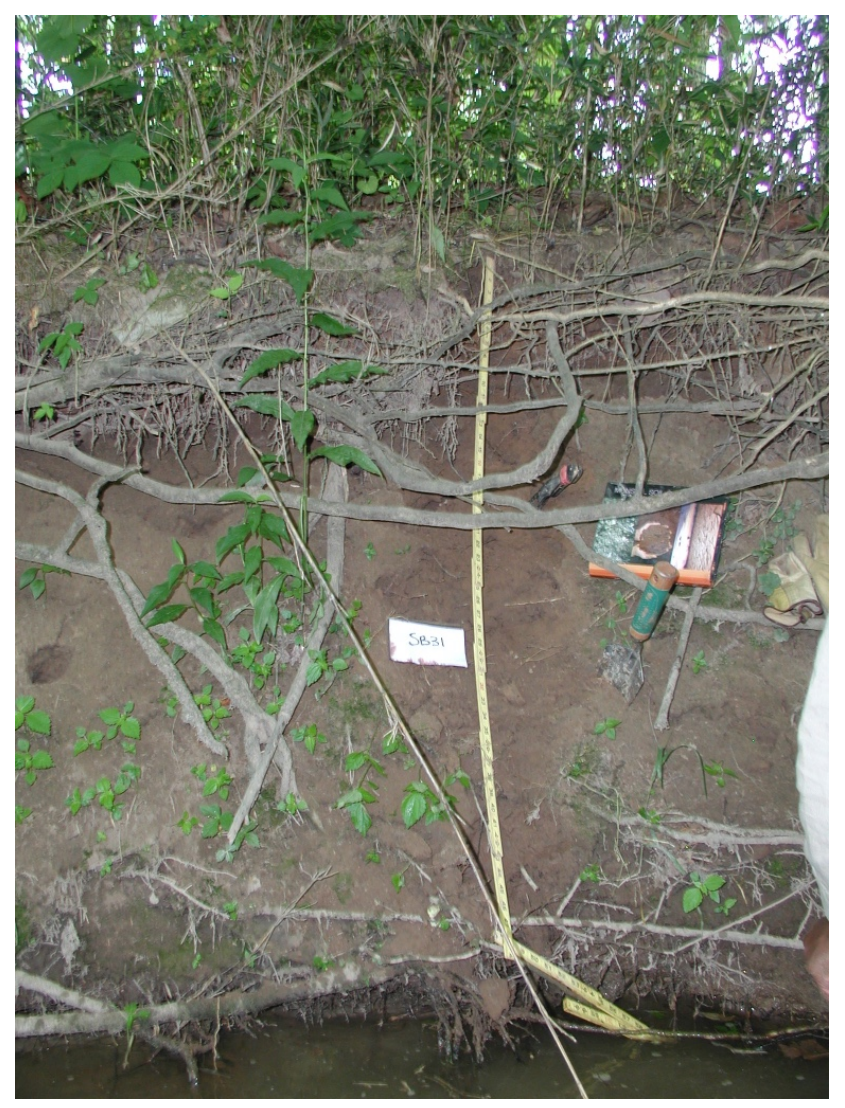

Site Evaluator's Signature: 


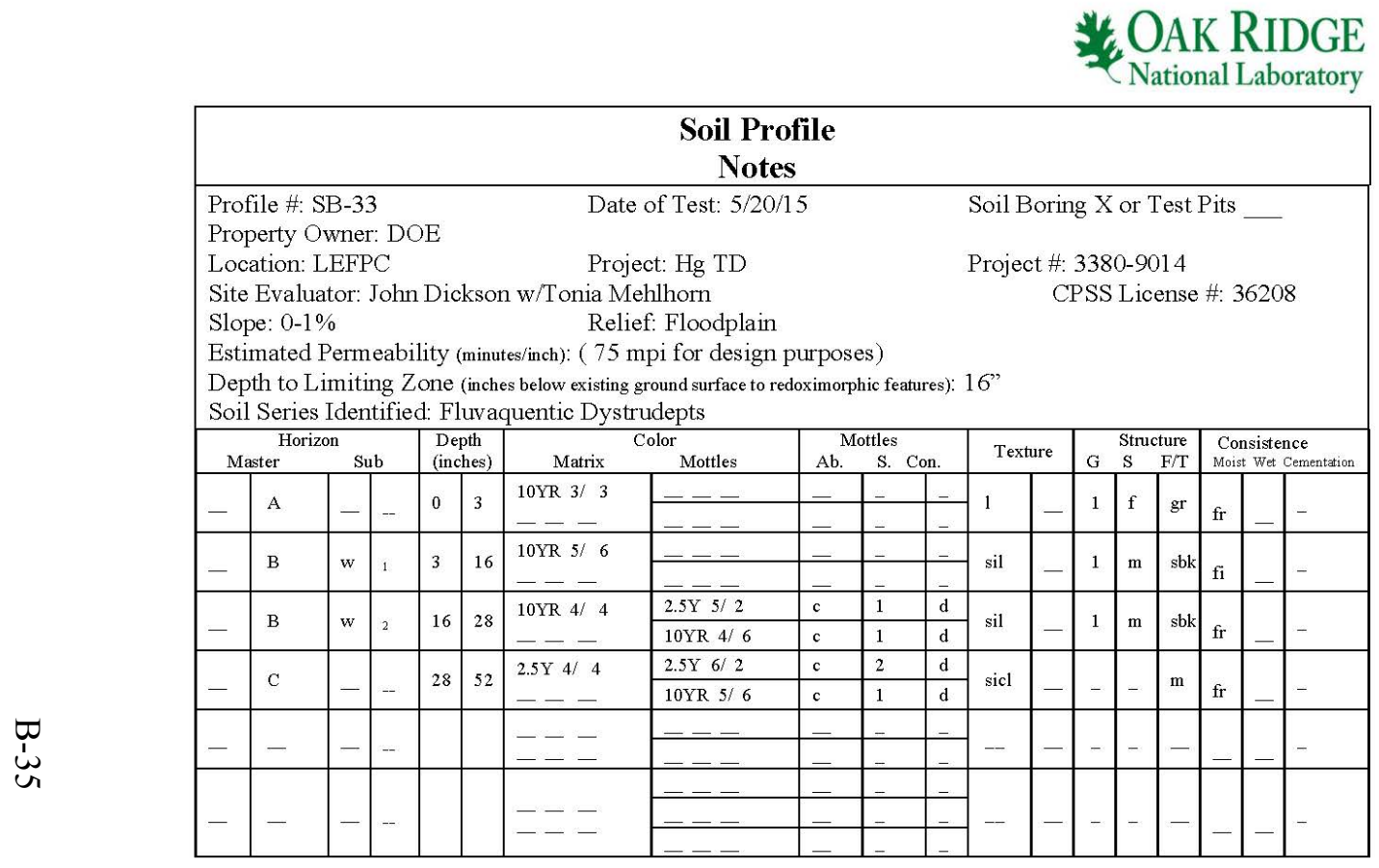

Comments:

GPS Coordinate: N: 35.99774 ; W: $-84.30349 \pm 14$

Depth to water surface in creek: $\sim 54$ " from top of bank.

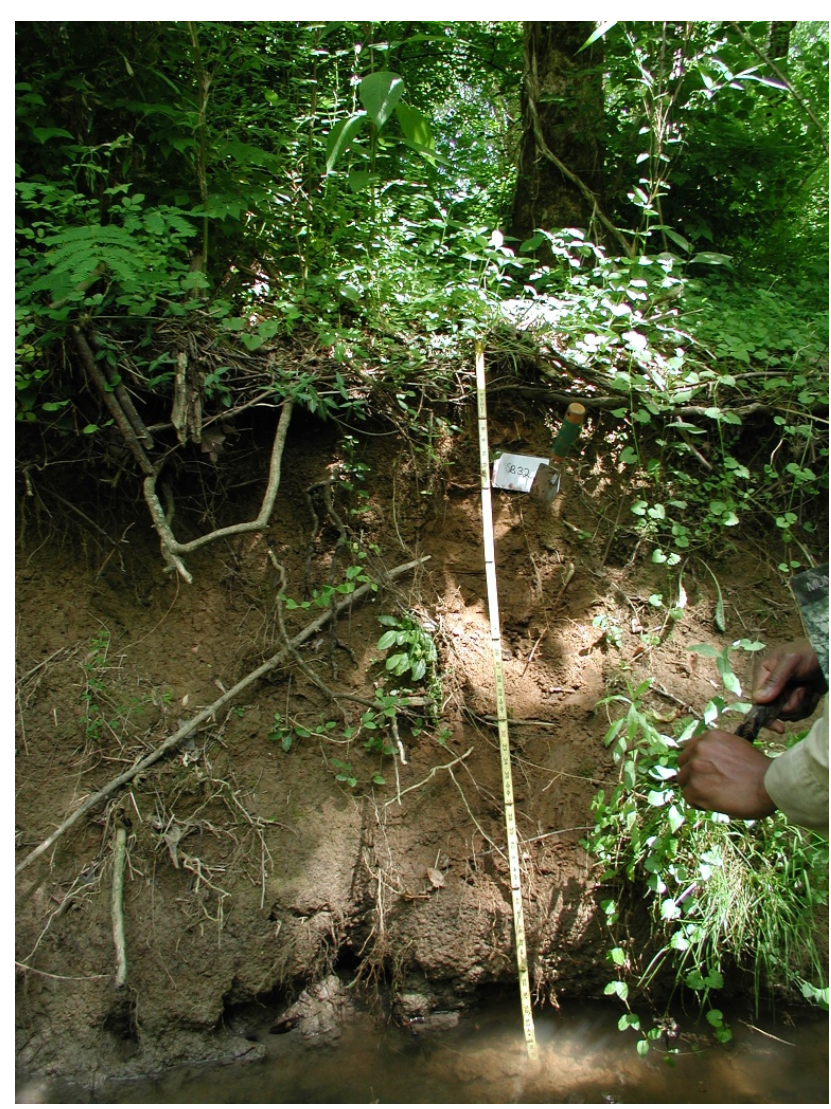




\section{OAK RIDGE}

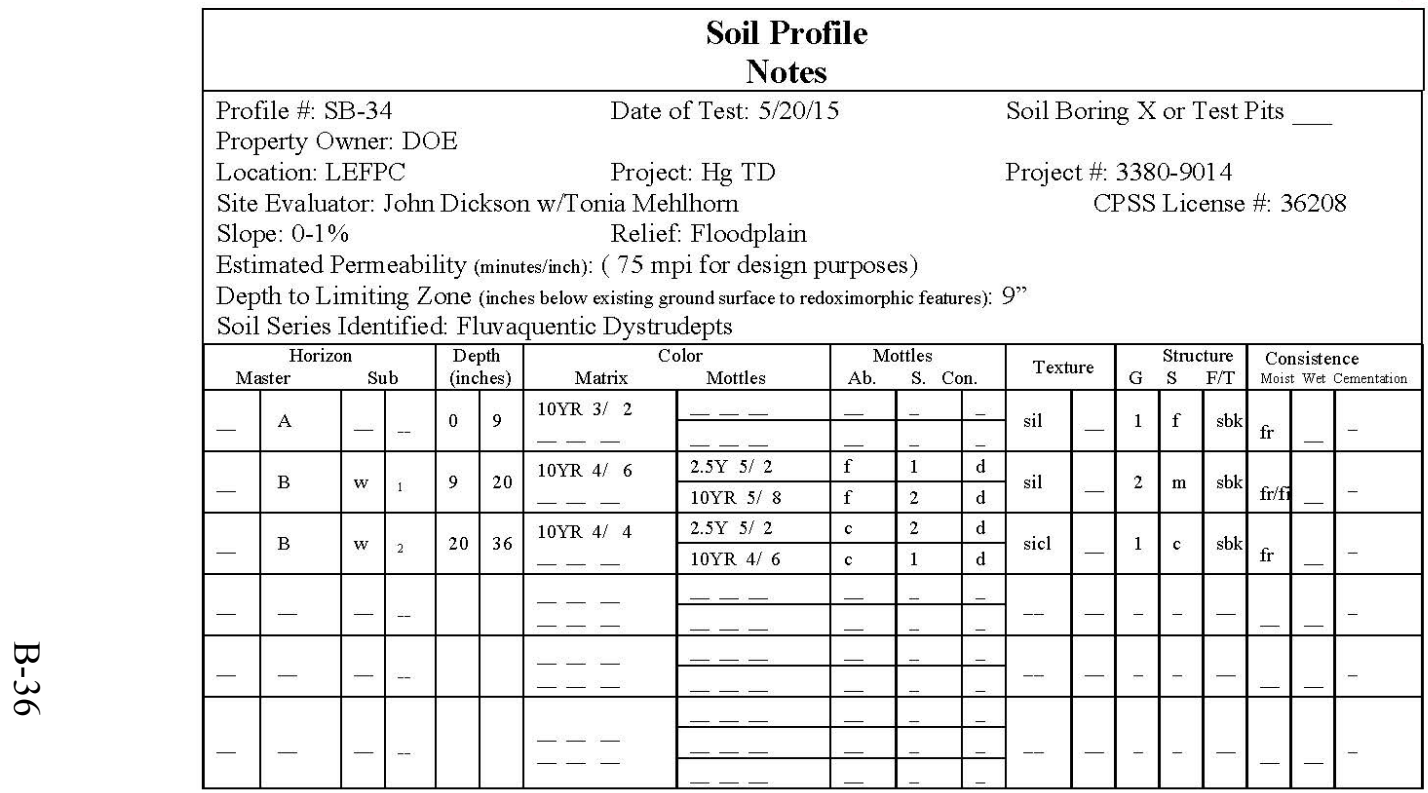

Comments:

GPS Coordinate: N: $35.99586 \cdot \mathrm{W} \cdot-84.30384$

Location prone to depositional erosion.

Depth to water surface in creek: $\sim 42 "$ from top of bank.

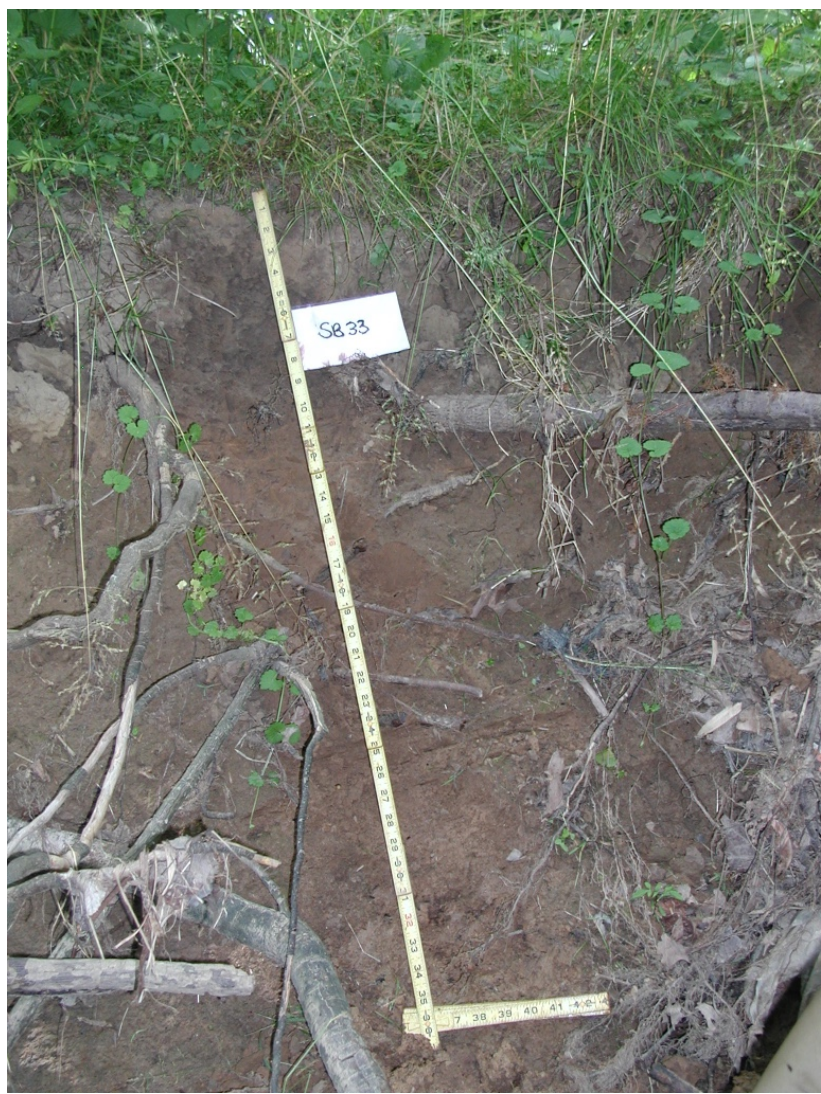




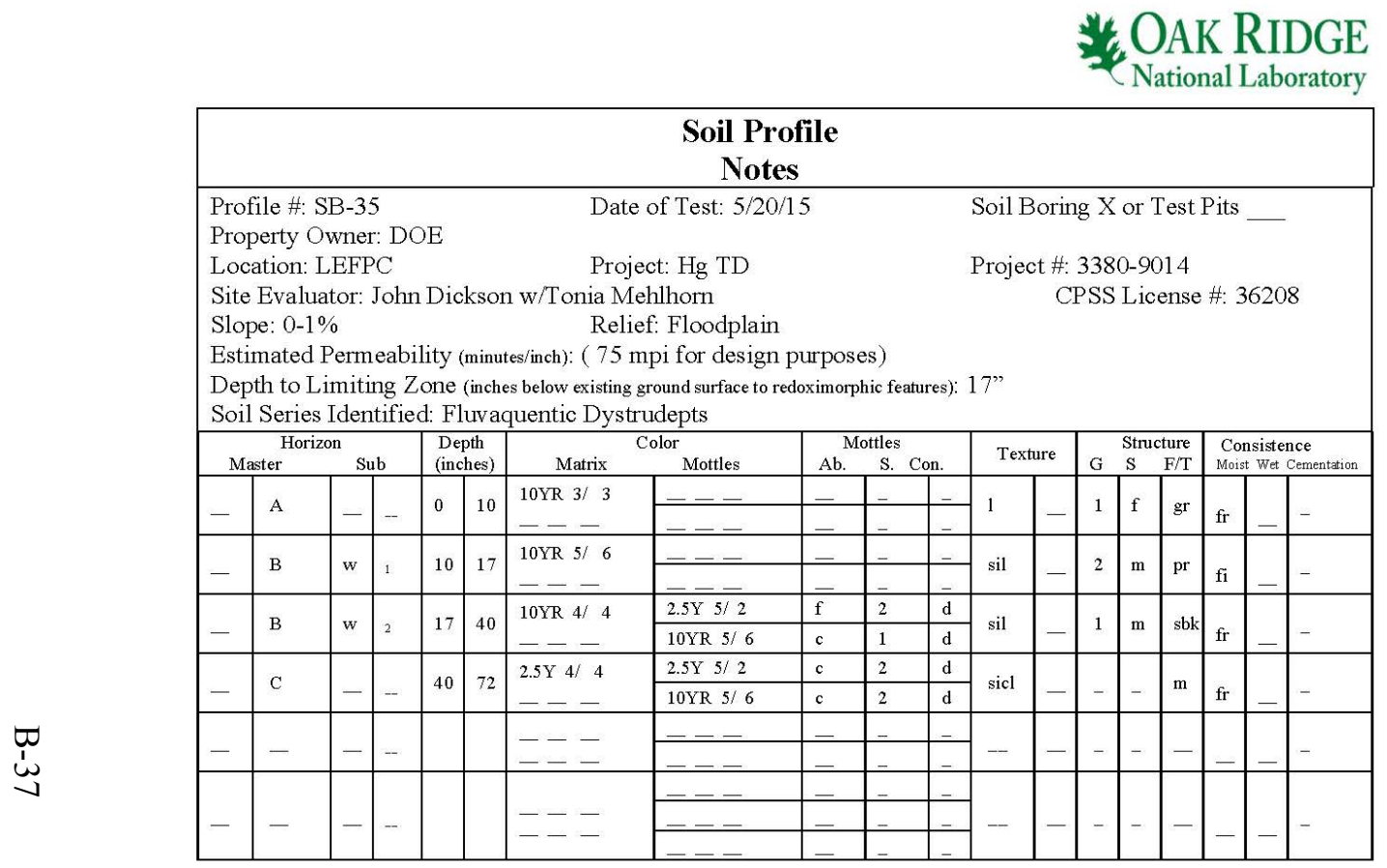

Comments:

GPS Coordinate: N: 35.99460 ; W: $-84.30592 \pm 15$

At 17-40 variegation 10YR 4/6, 2.5Y 5/4 and 10YR $2 / 1$ black (Mn) concretions Location prone to depositional erosion.

Depth to water surface in creek: $\sim 84$ " from top of bank.

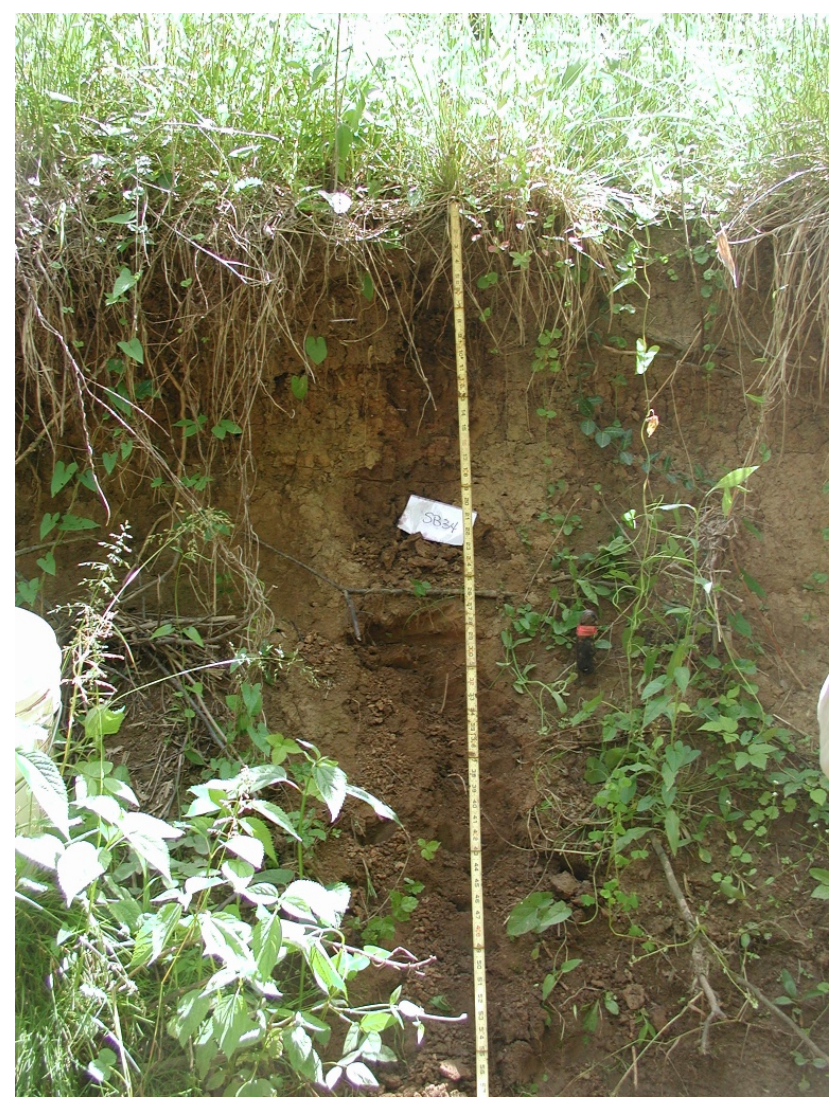




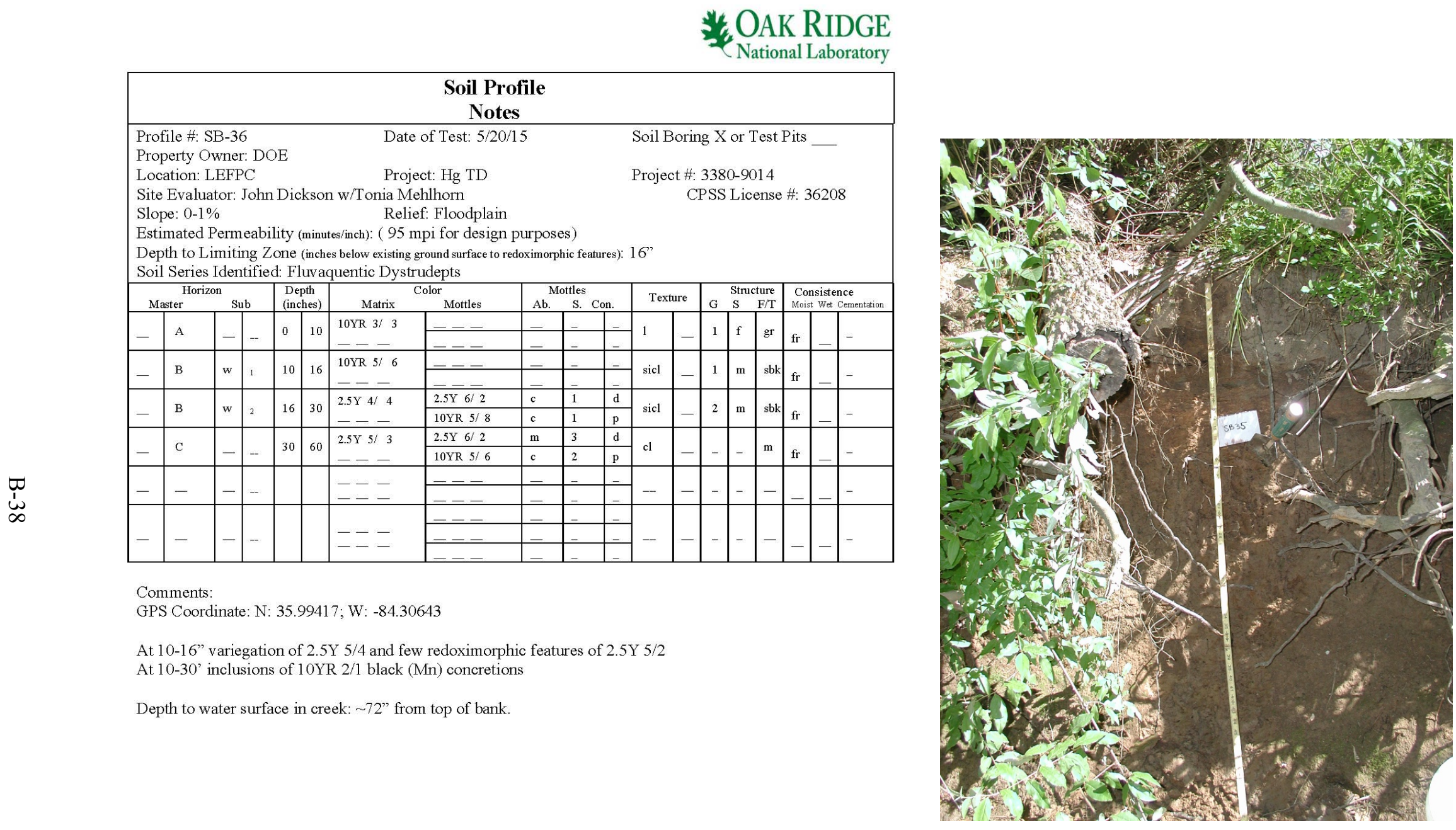

Site Evaluator's Signature: 


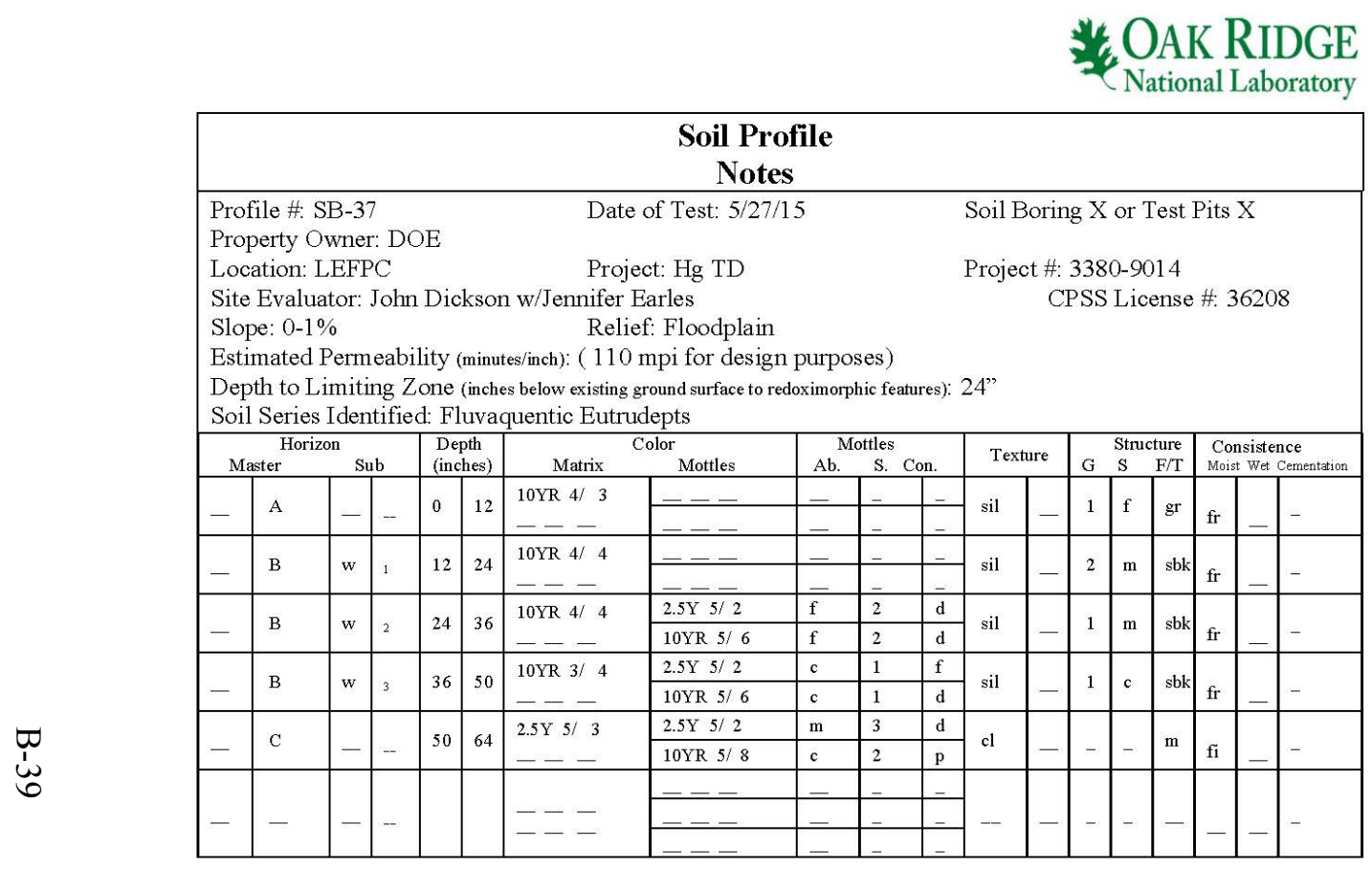

Comments:

GPS Coordinate: N: 35.99248 ; W: $-84.30910 \pm 6.7$

At 24-50" inclusions of 10YR 2/1 black (Mn) concretions

Rocky outcrops on opposite bank of creek

Depth to water surface in creek: $\sim 64$ " from top of bank.

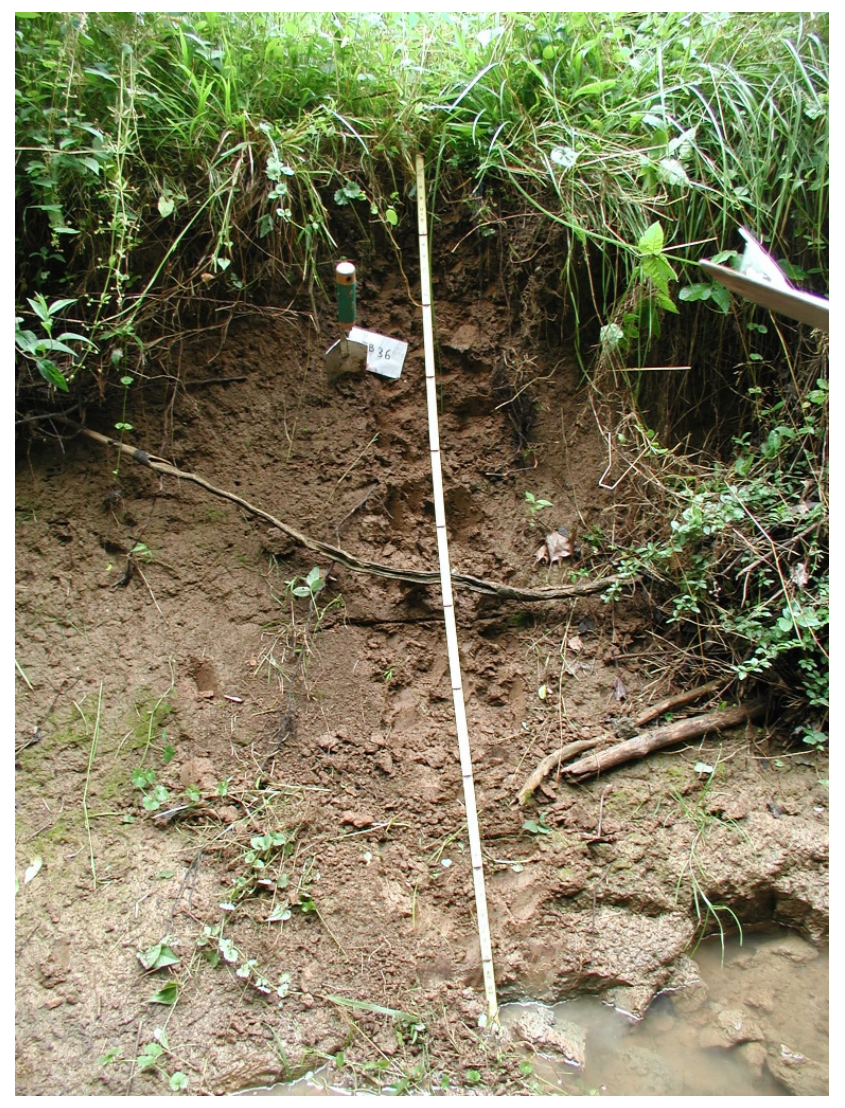




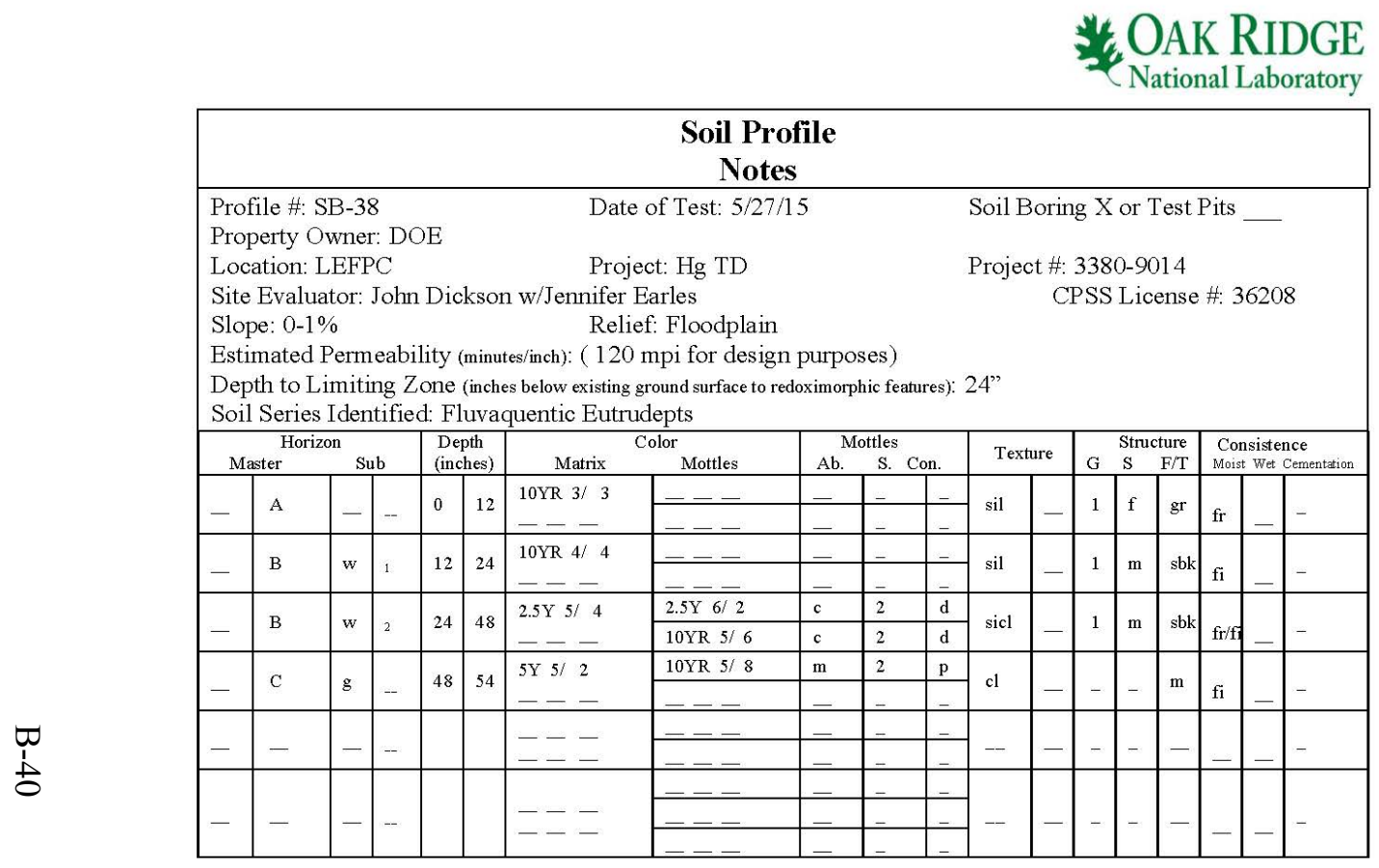

Comments

GPS Coordinate: N: 35.99090; W: -84.31233

At 12-24" inclusions of few 10YR 2/1 black (Mn) concretions

Depth to water surface in creek: $~ 54$ " from top of bank.

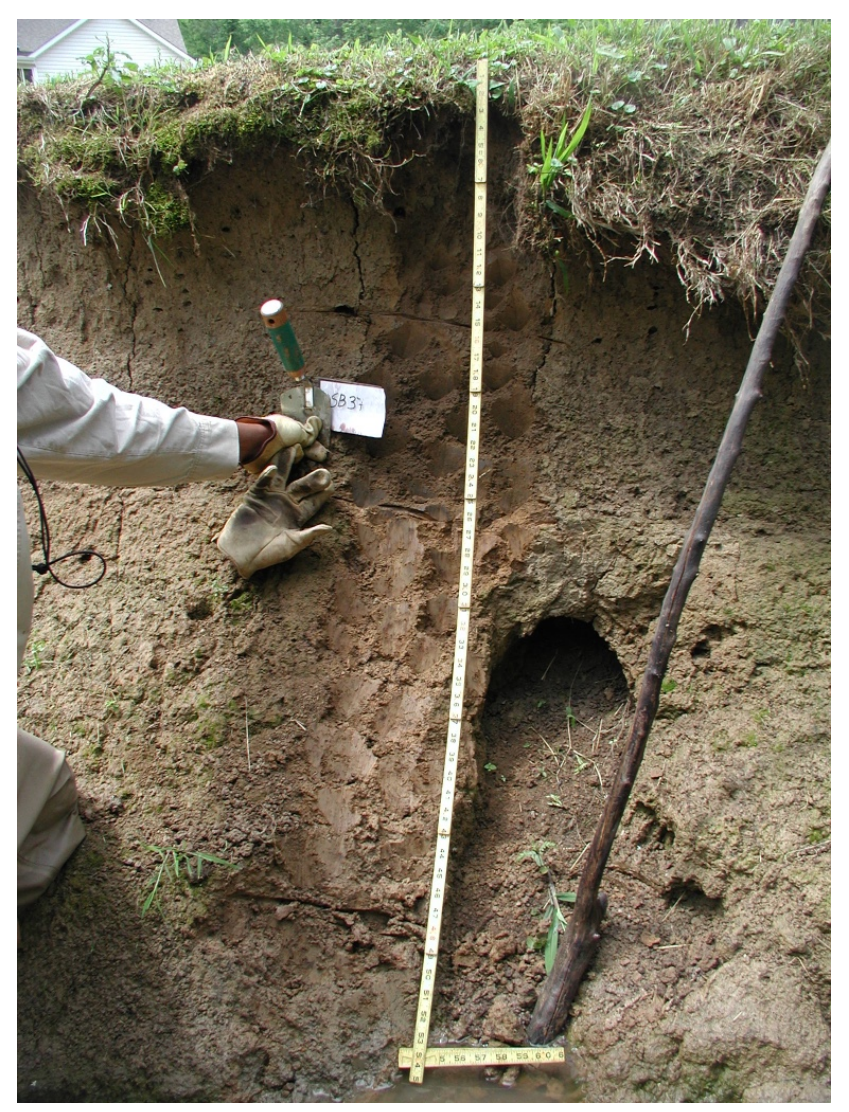




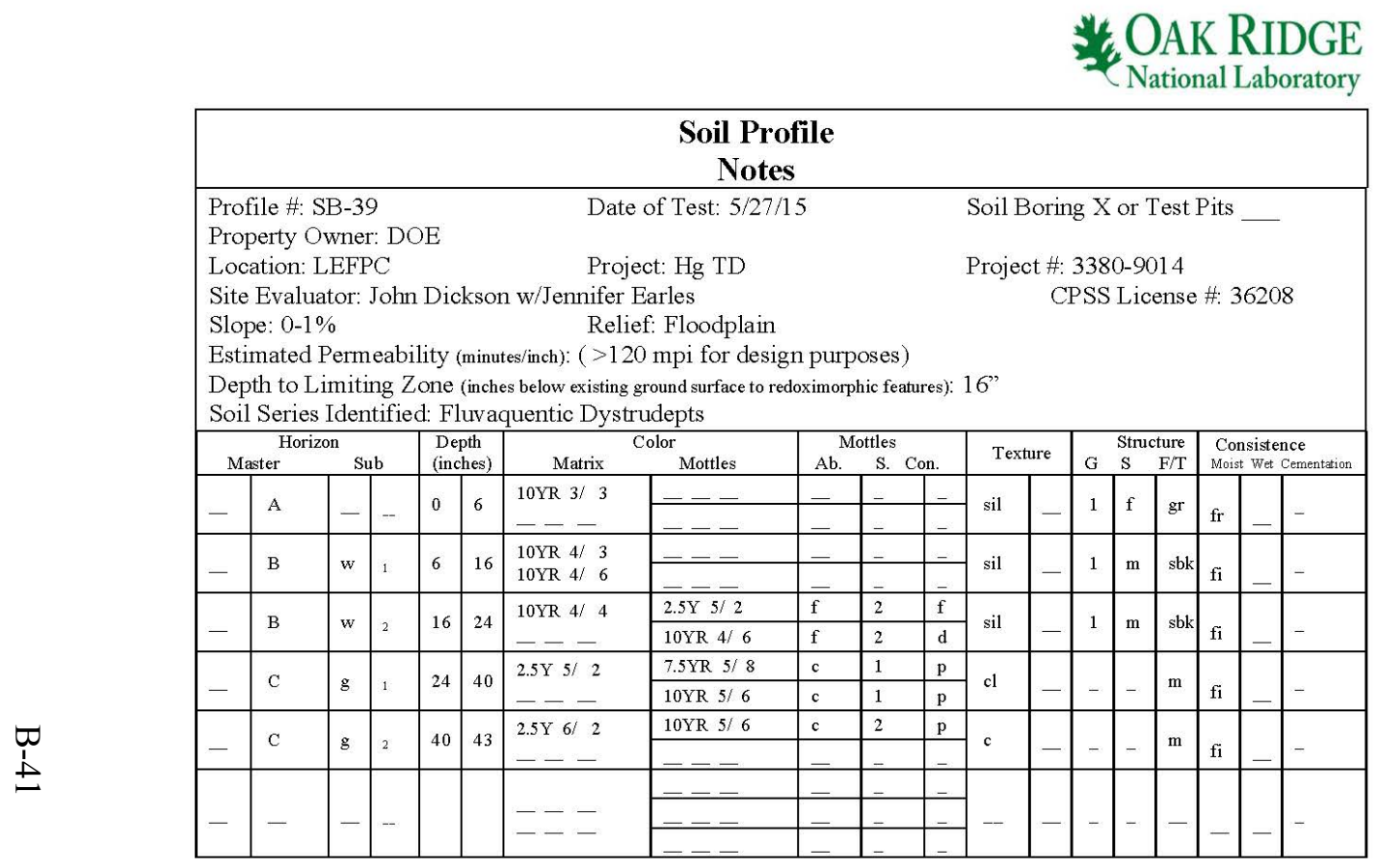

Comments:

GPS Coordinate: N: 35.99255 ; W: -84.31299

At 6-24" horizons are dry and very firm with some inclusions of prismatic structures

Depth to water surface in creek: $\sim 43$ " from top of bank.

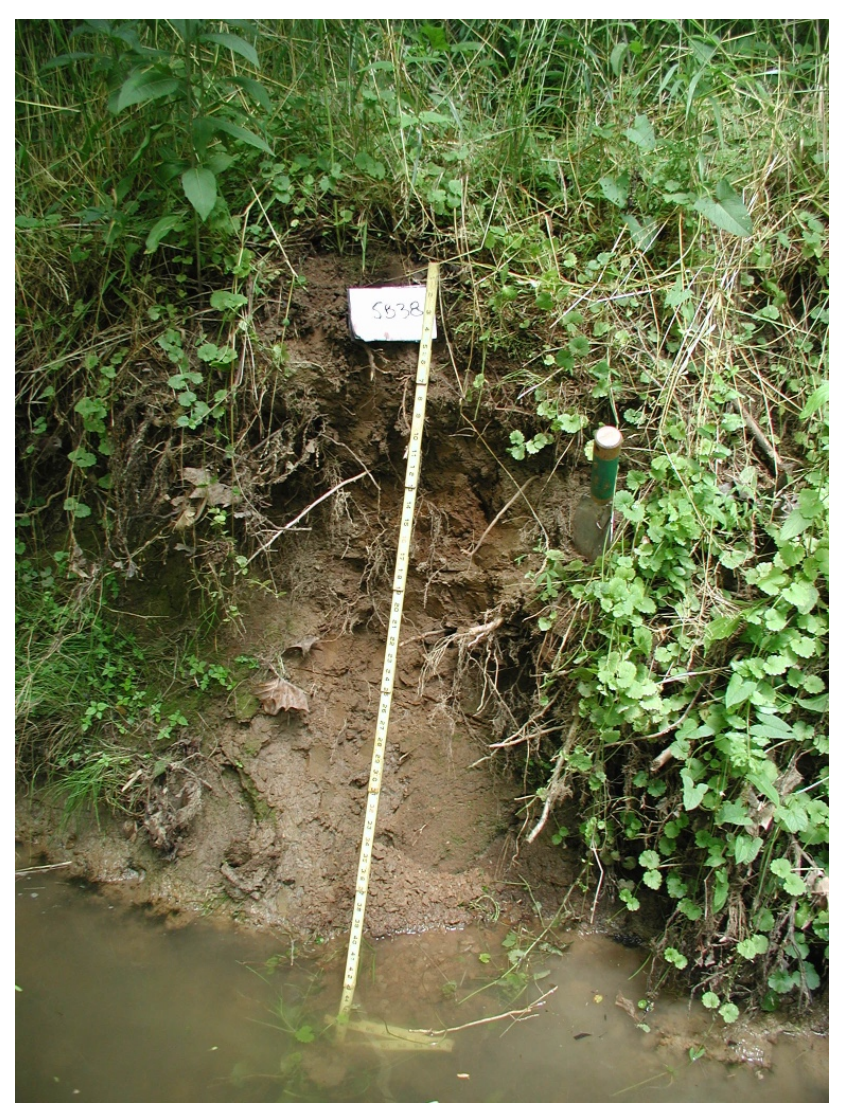




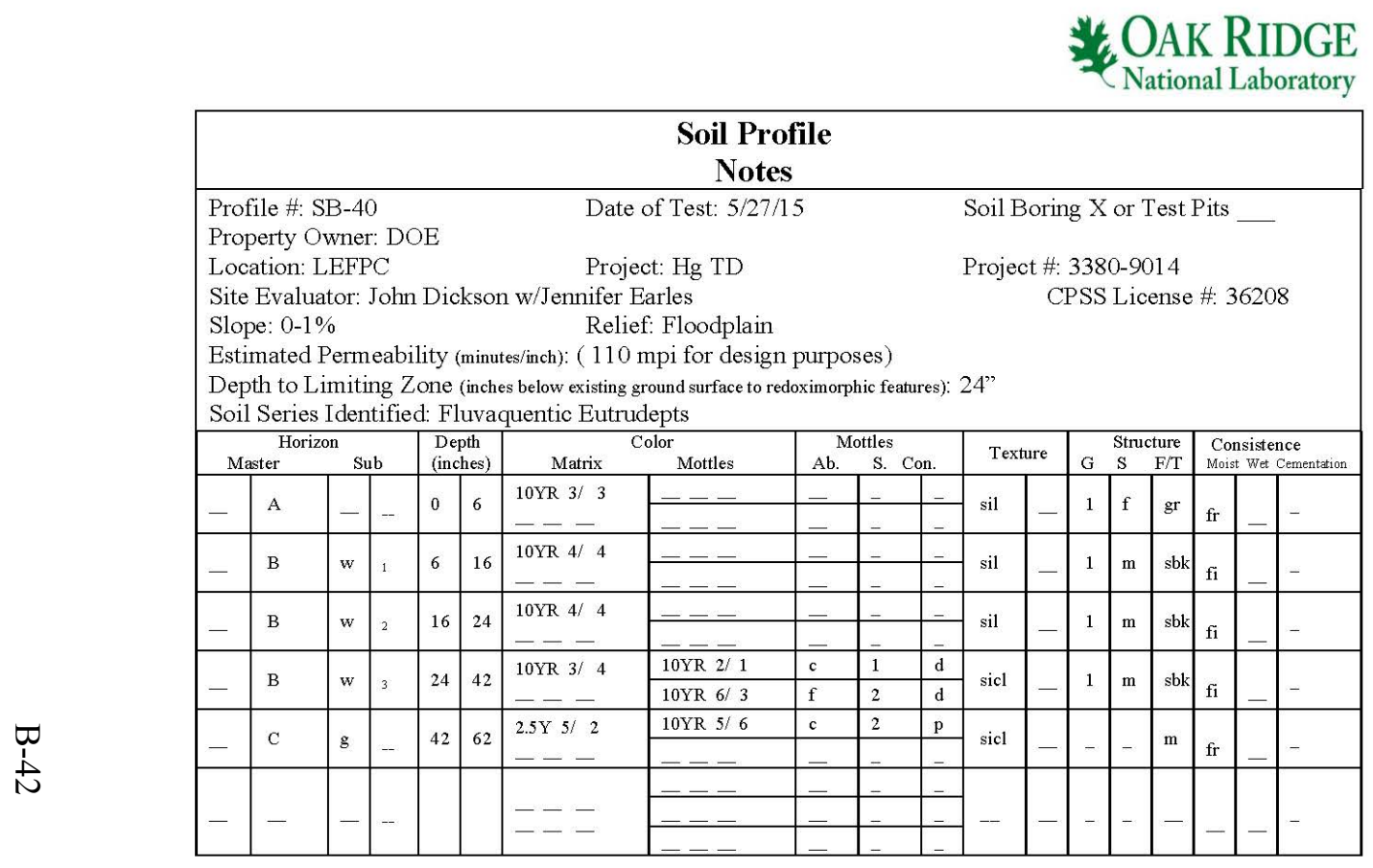

Comments

GPS Coordinate: N: 35.99291 ; W: -84.31484

At 24-42" some 10YR 2/1 Mn concretions

Depth to water surface in creek: 62 " from top of bank.

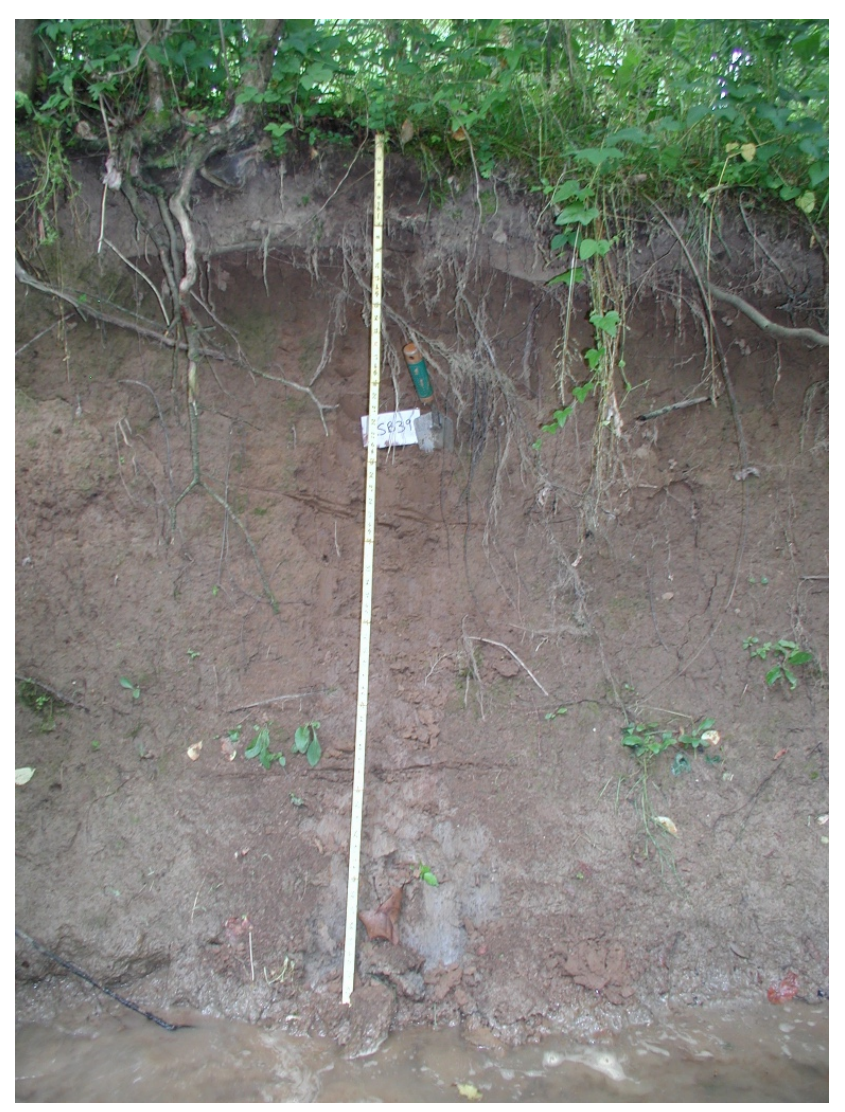




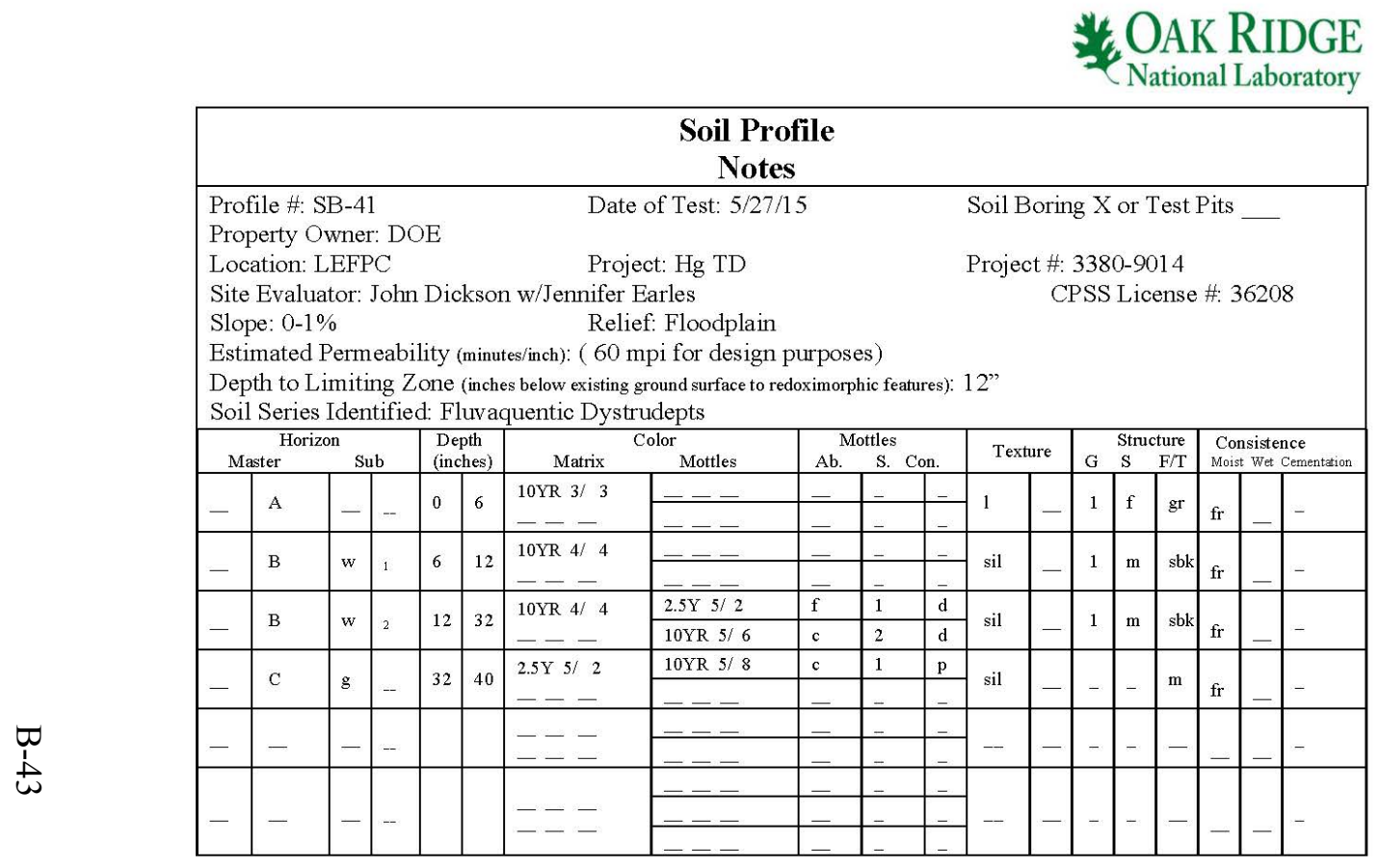

Comments:

GPS Coordinate: N: 35.99120; W: -84.31606

Depth to water surface in creek: $\sim 40$ " from top of bank.

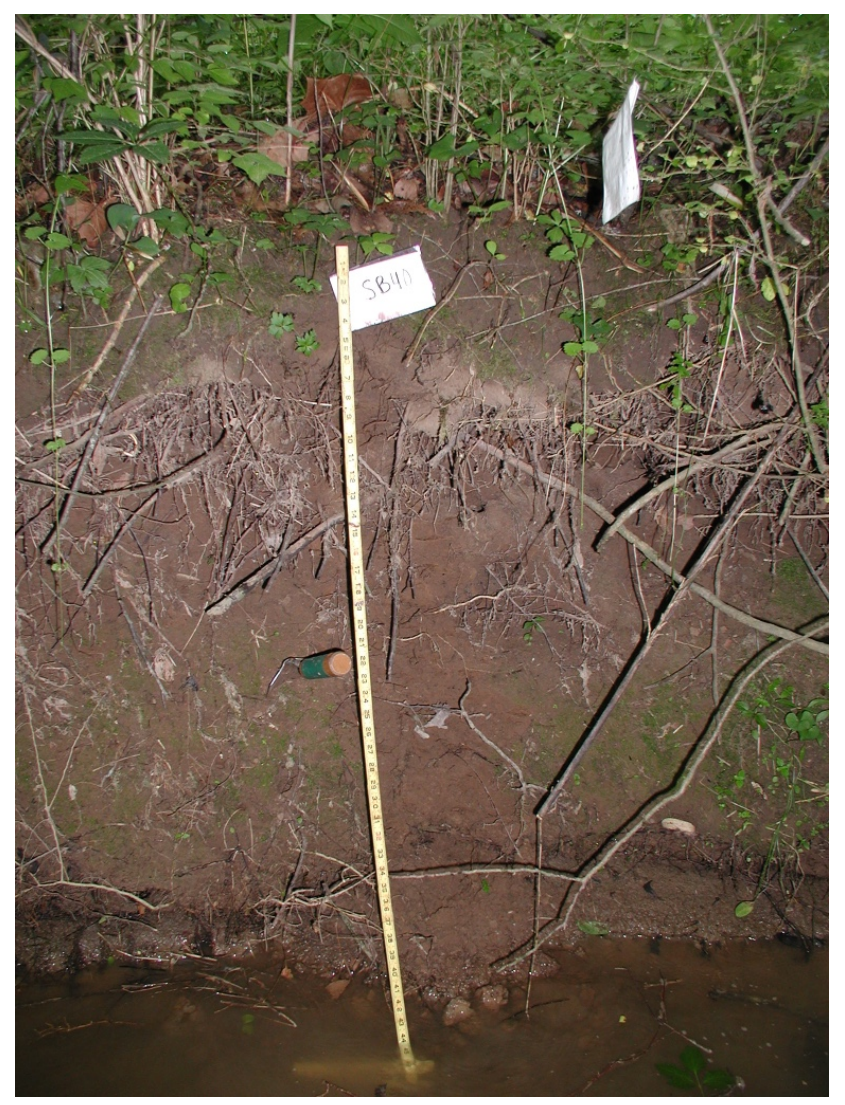




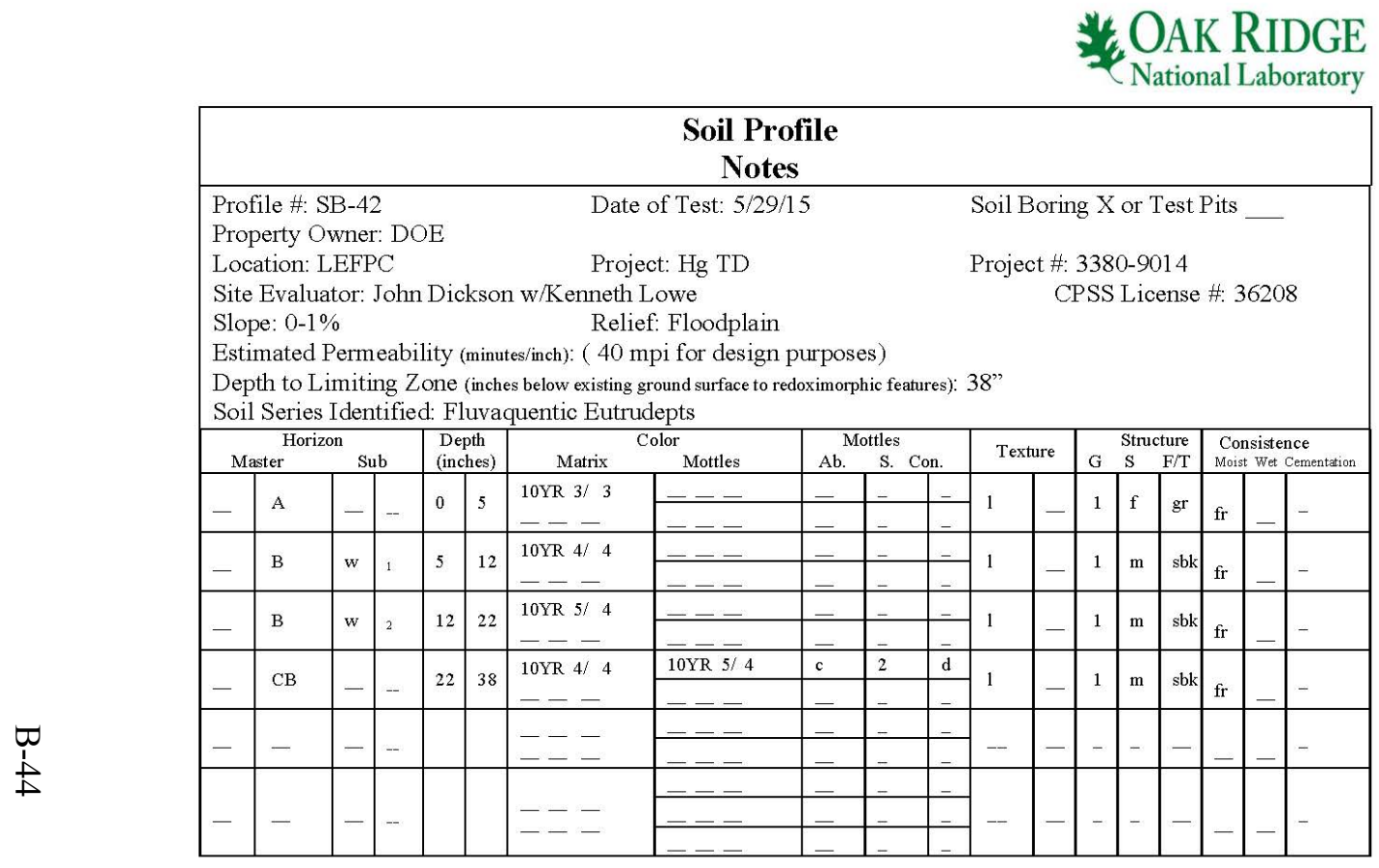

Comments:

GPS Coordinate: N: 35.98987 ; W: -84.31950

At 22-38" common medium and distinct 10YR 5/4 variegations Bedrock at 38 "

Depth to water surface in creek: 96 " from top of bank.

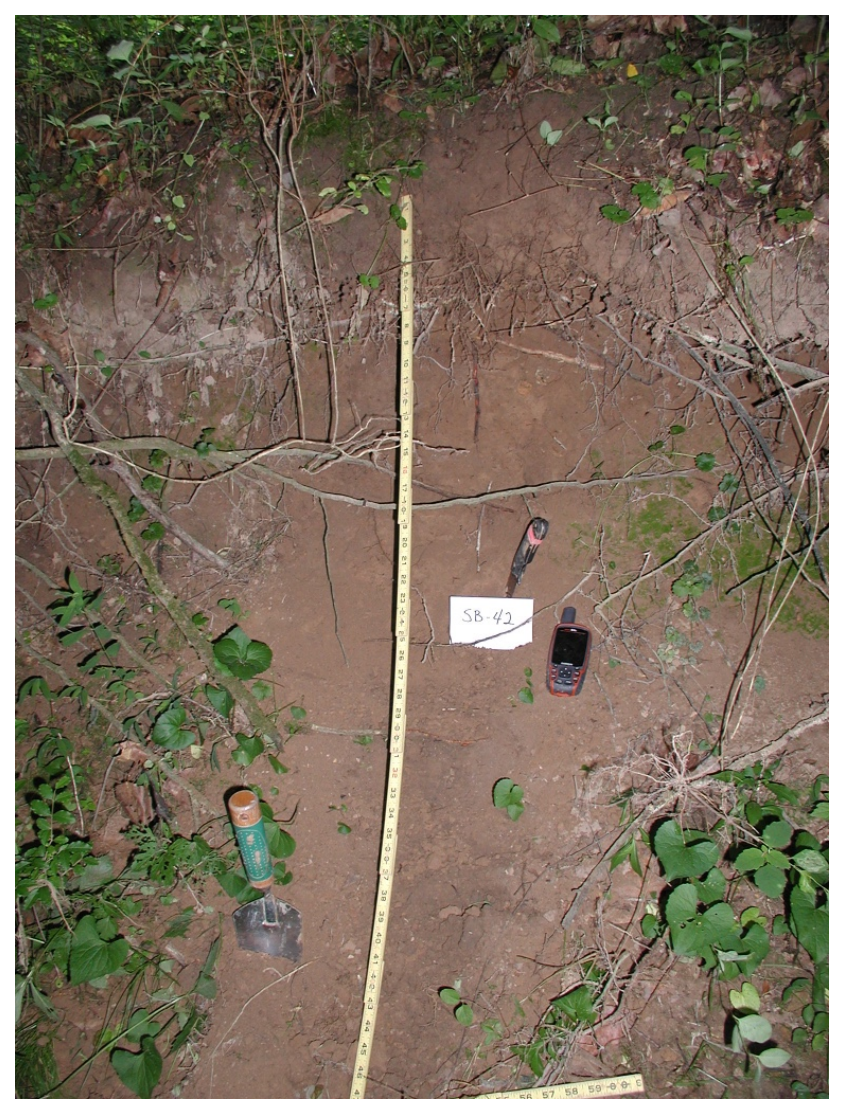




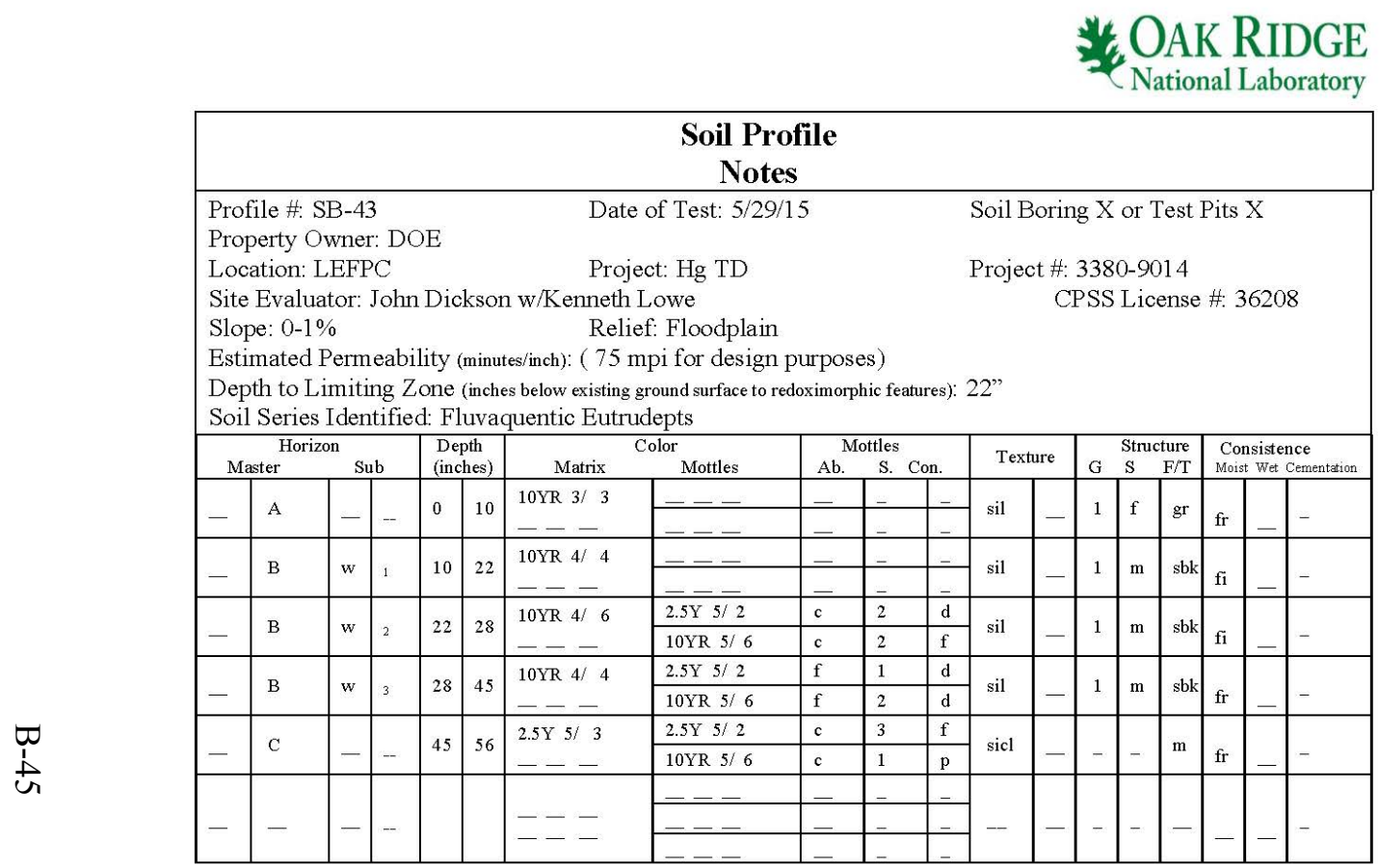

Comments:

GPS Coordinate: N: 35.98207 ; W: -84.32604

Rock outcrops on opposite creek bank

Depth to water surface in creek: $\sim 56$ " from top of bank.

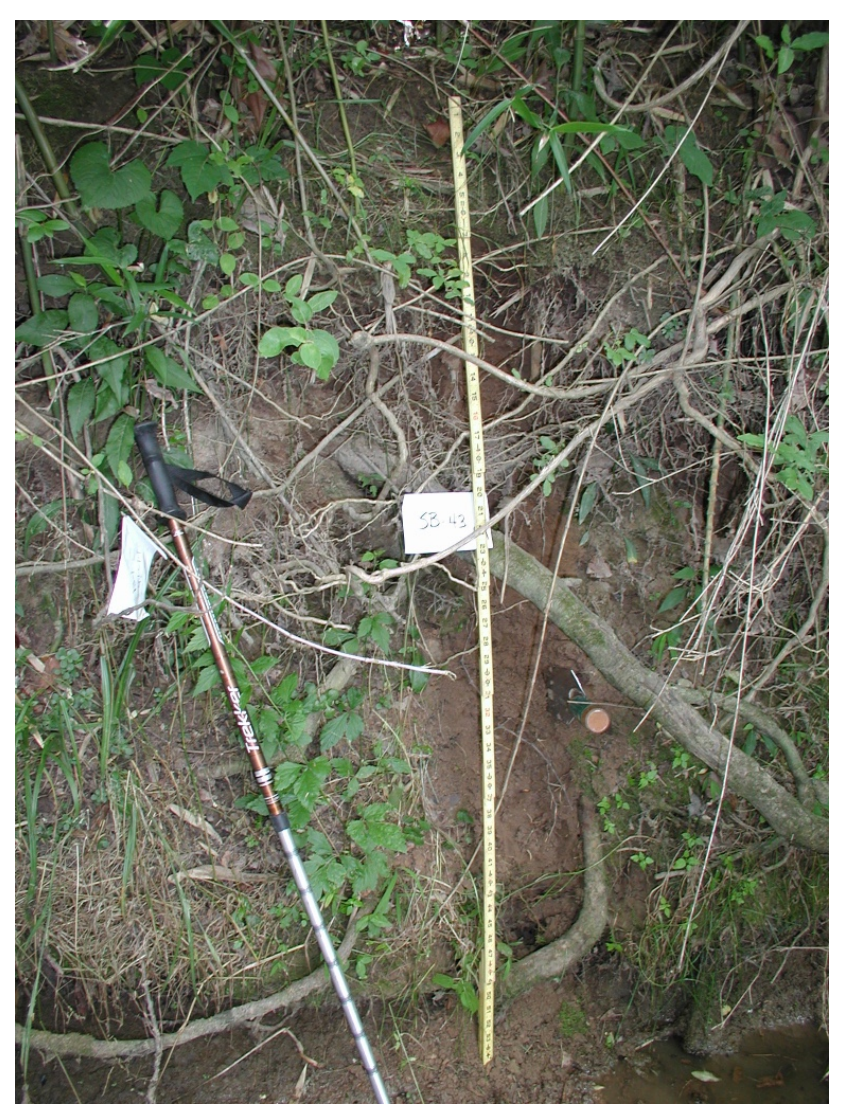




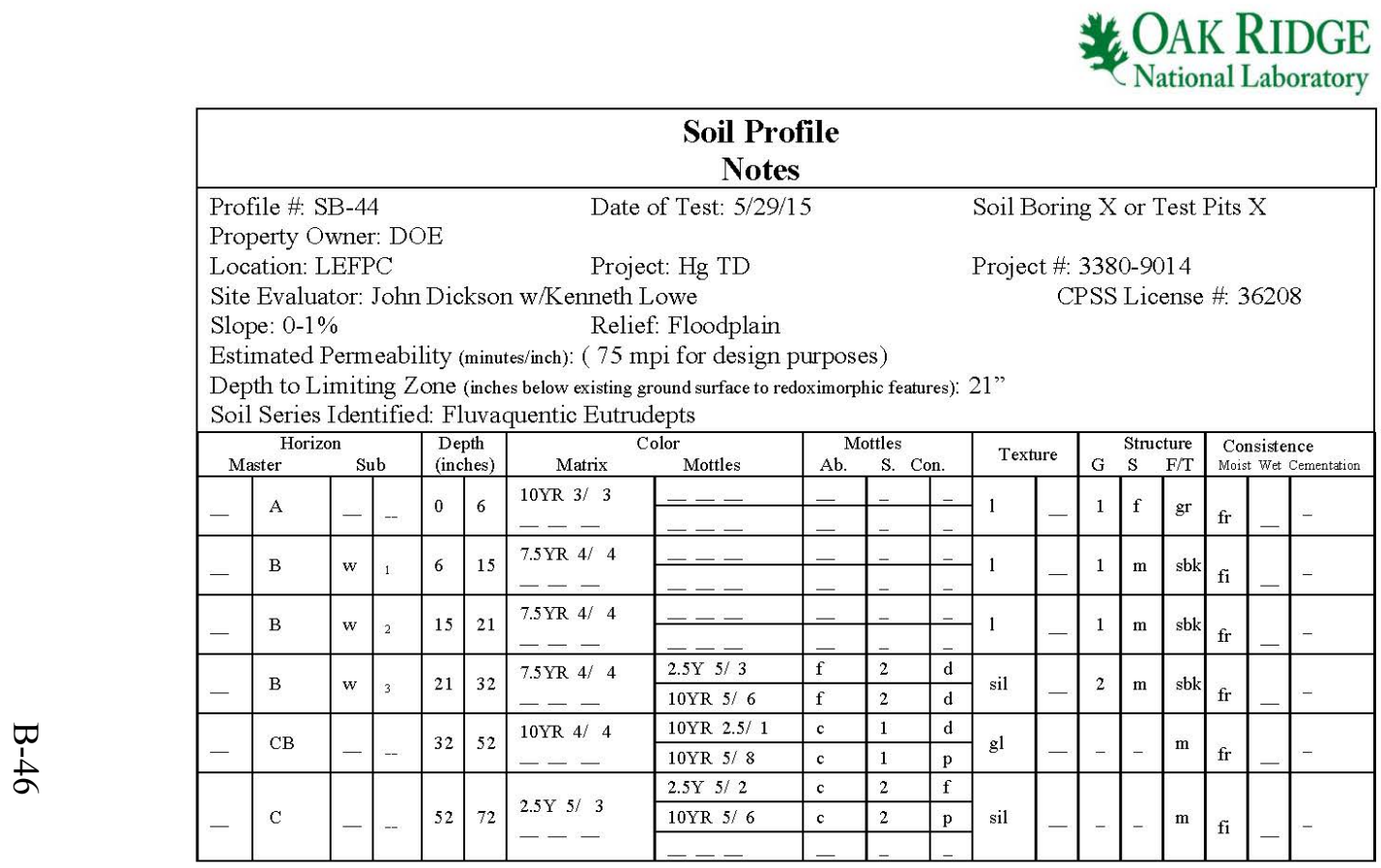

Comments:

GPS Coordinate: N: 35.98190 ; W: -84.32745

At 15-21" loam grading to silt loam, firm in places

At 32-52" lenses of coarse sands

Depth to water surface in creek: $\sim 72$ " from top of bank.

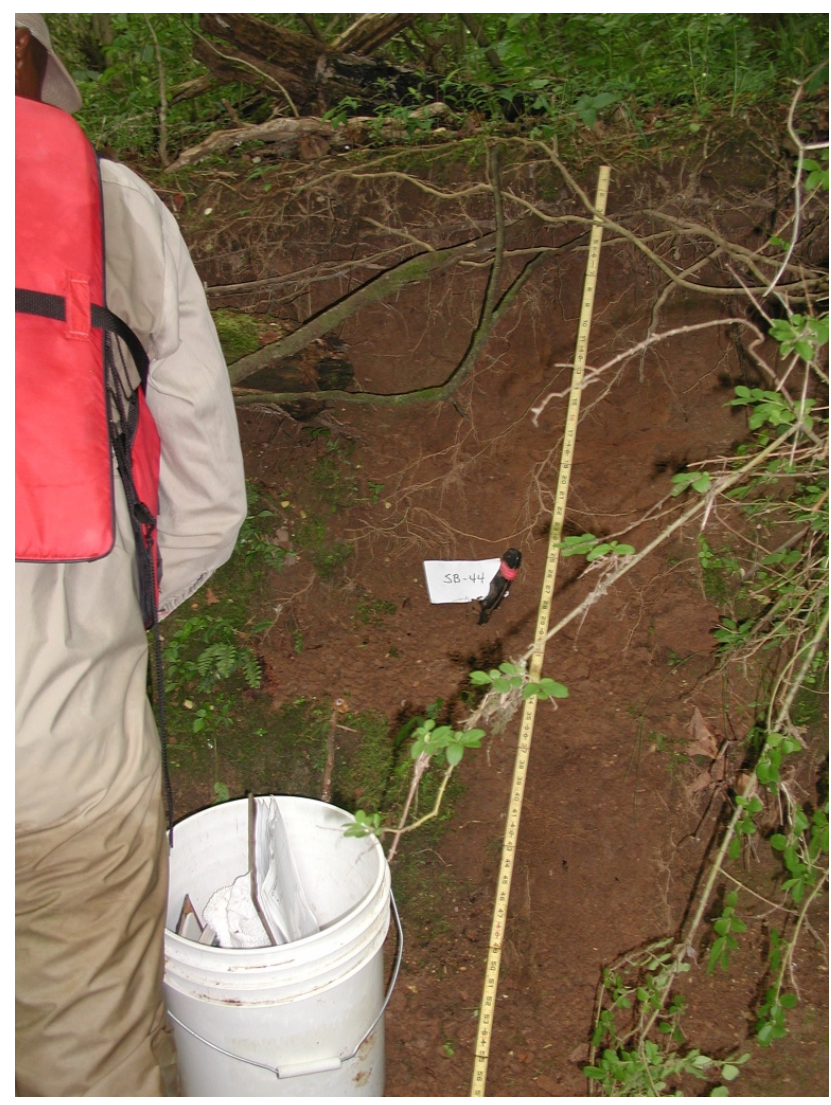




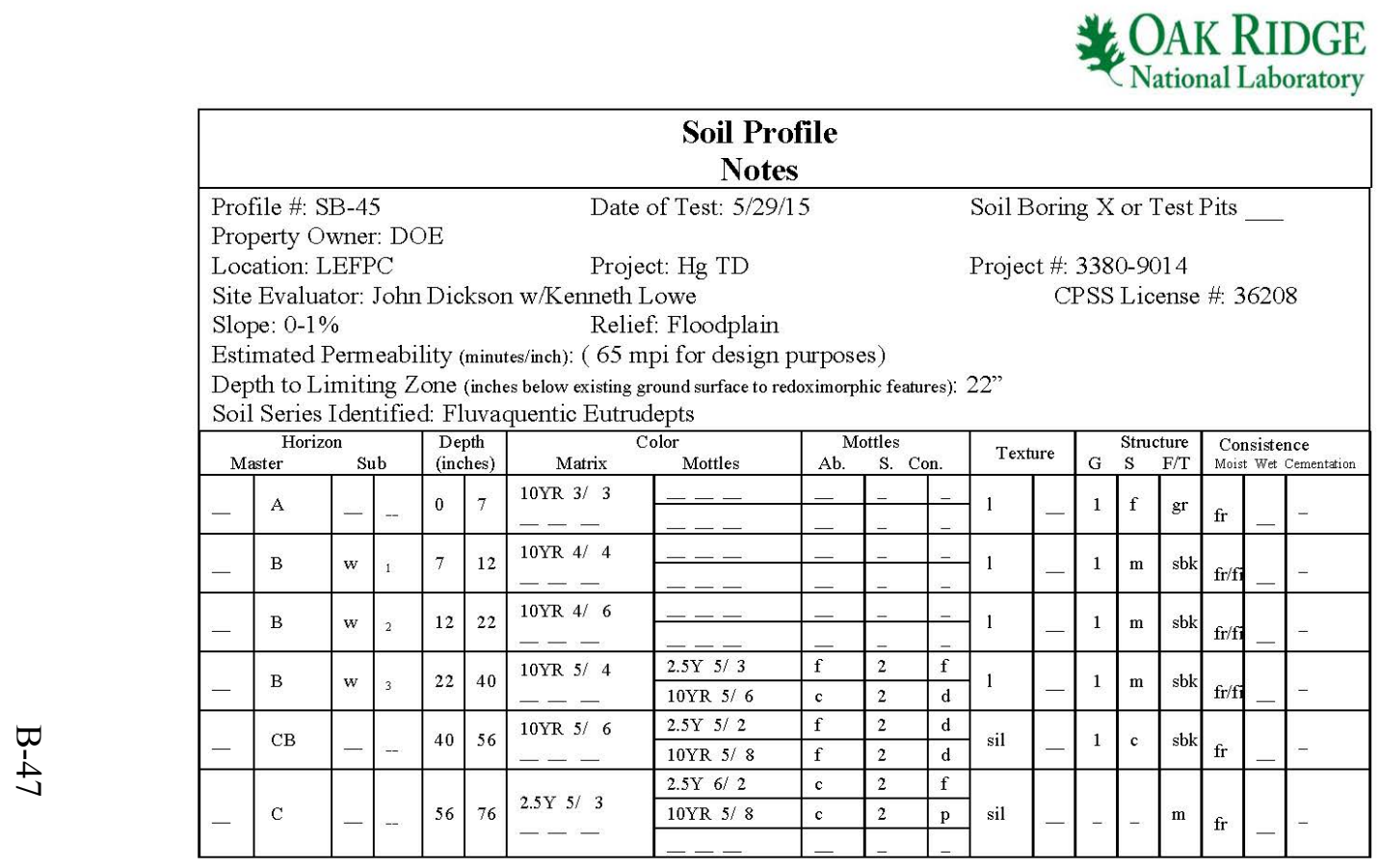

Comments

GPS Coordinate: N: 35.97986 ; W: -84.33002

At 22-56" inclusions of $10 \mathrm{YR} 4 / 3$ variegation

Depth to water surface in creek: 76 " from top of bank.

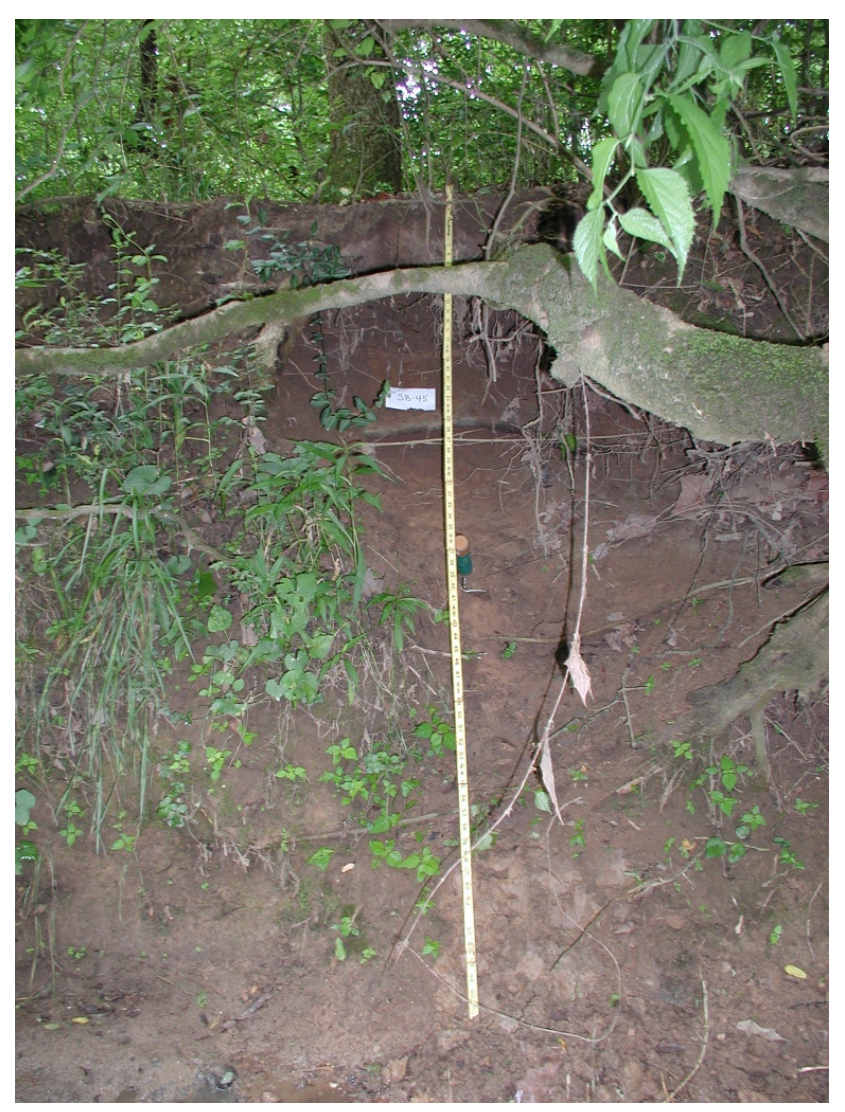




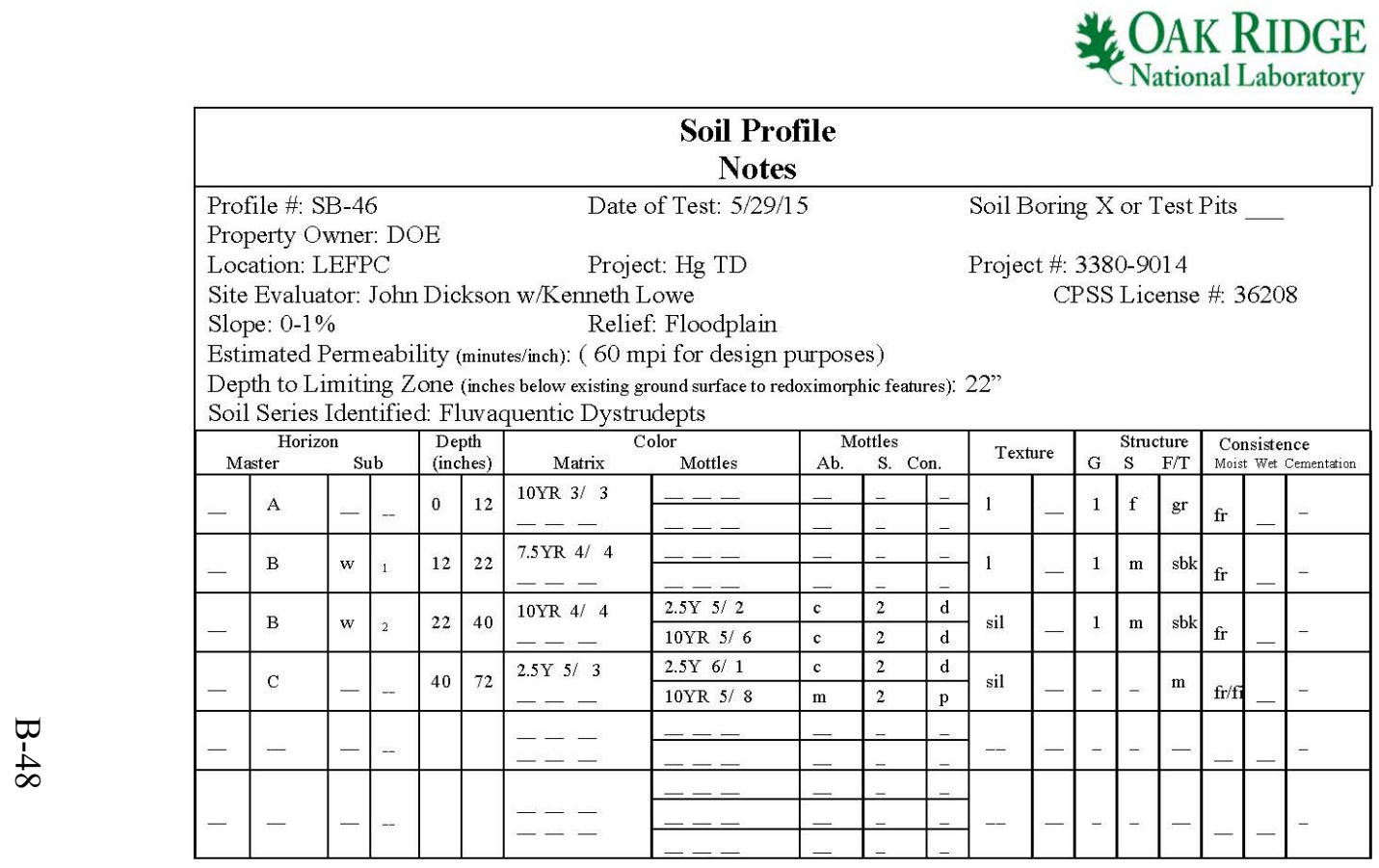

Comments:

GPS Coordinate: N: 35.97903 ; W: -84.33080

Below 72 " very firm silty clay loam grading to clay loam

Depth to water surface in creek: $\sim 72$ " from top of bank.

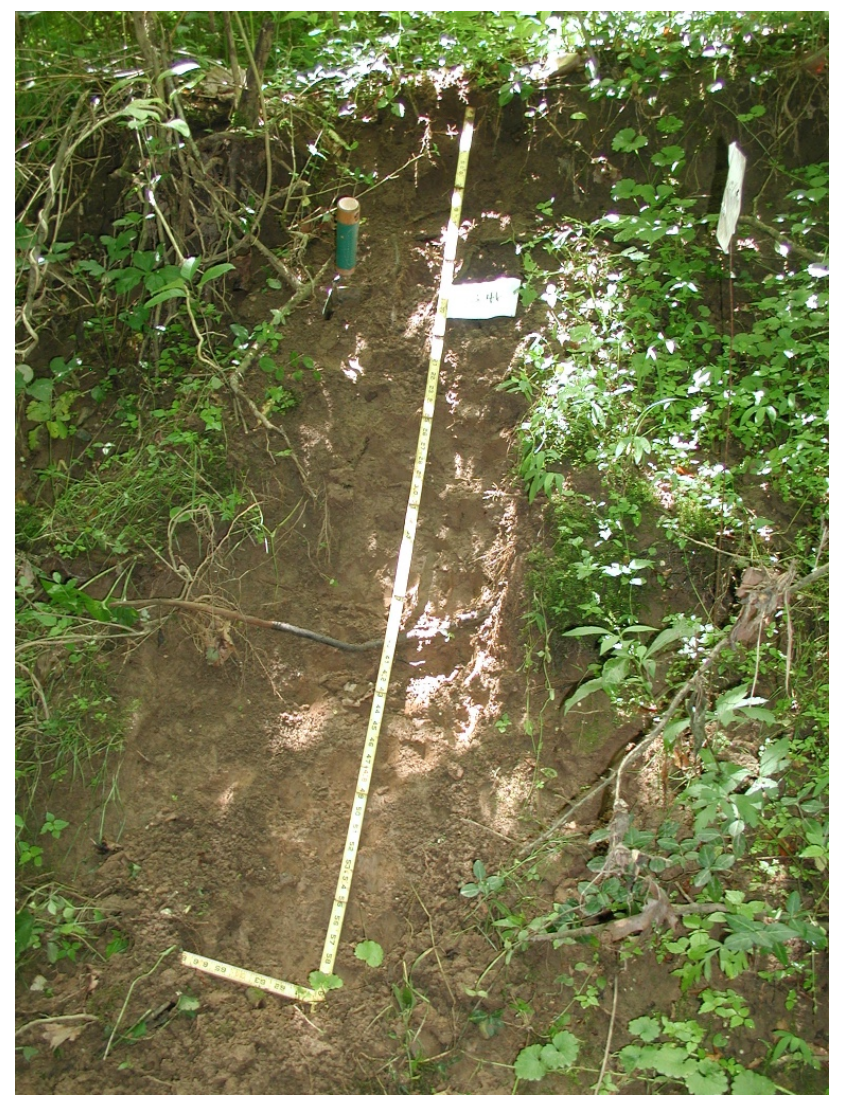




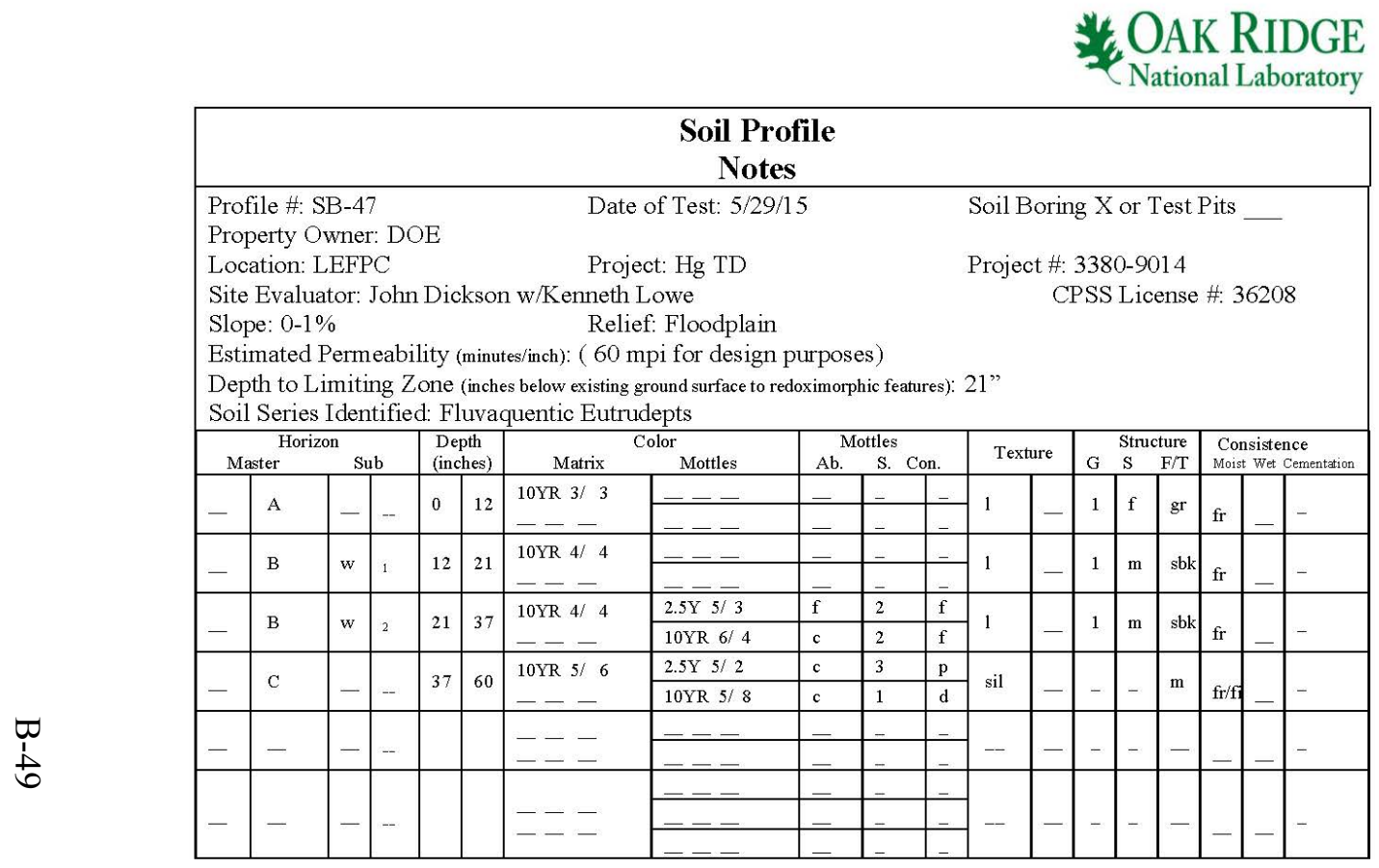

Comments:

GPS Coordinate: N: $35.97827 ; \mathrm{W}:-84.33189$

At 21-37" inclusions of few fine distinct 10YR 2/1 Mn concretions

Depth to water surface in creek: $\sim 72$ " from top of bank.

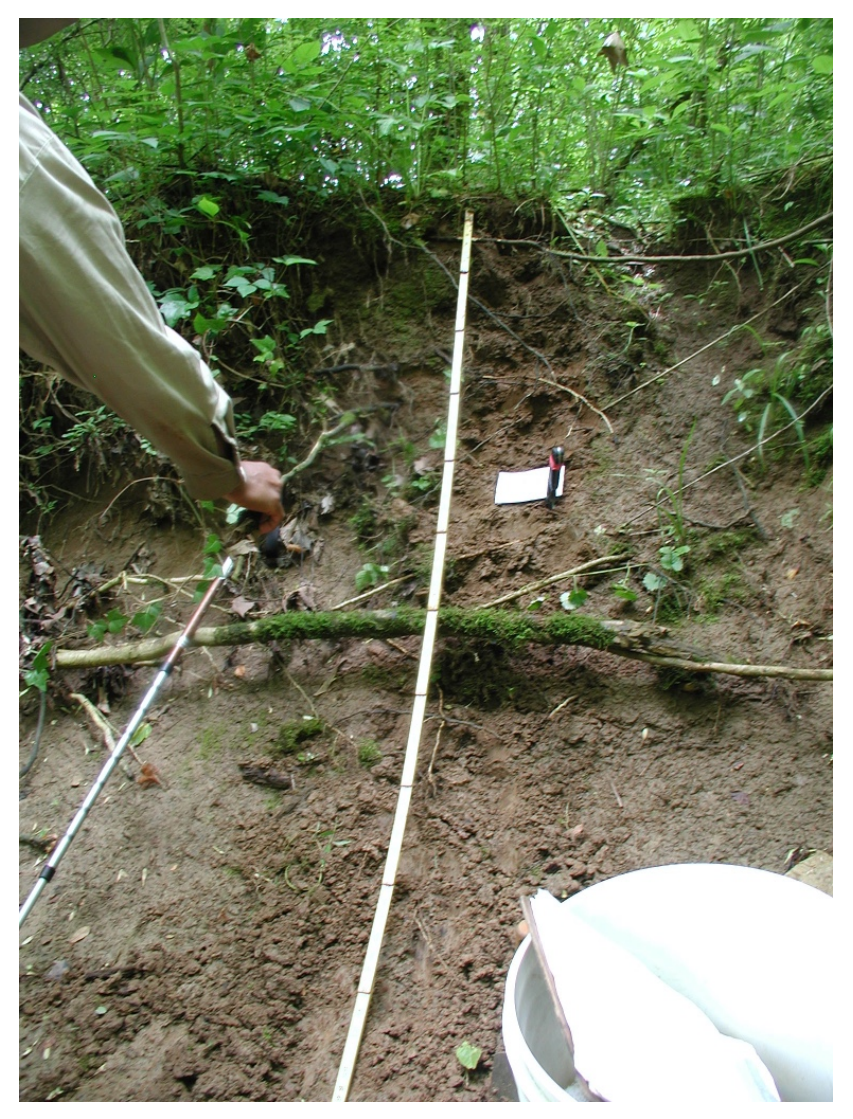




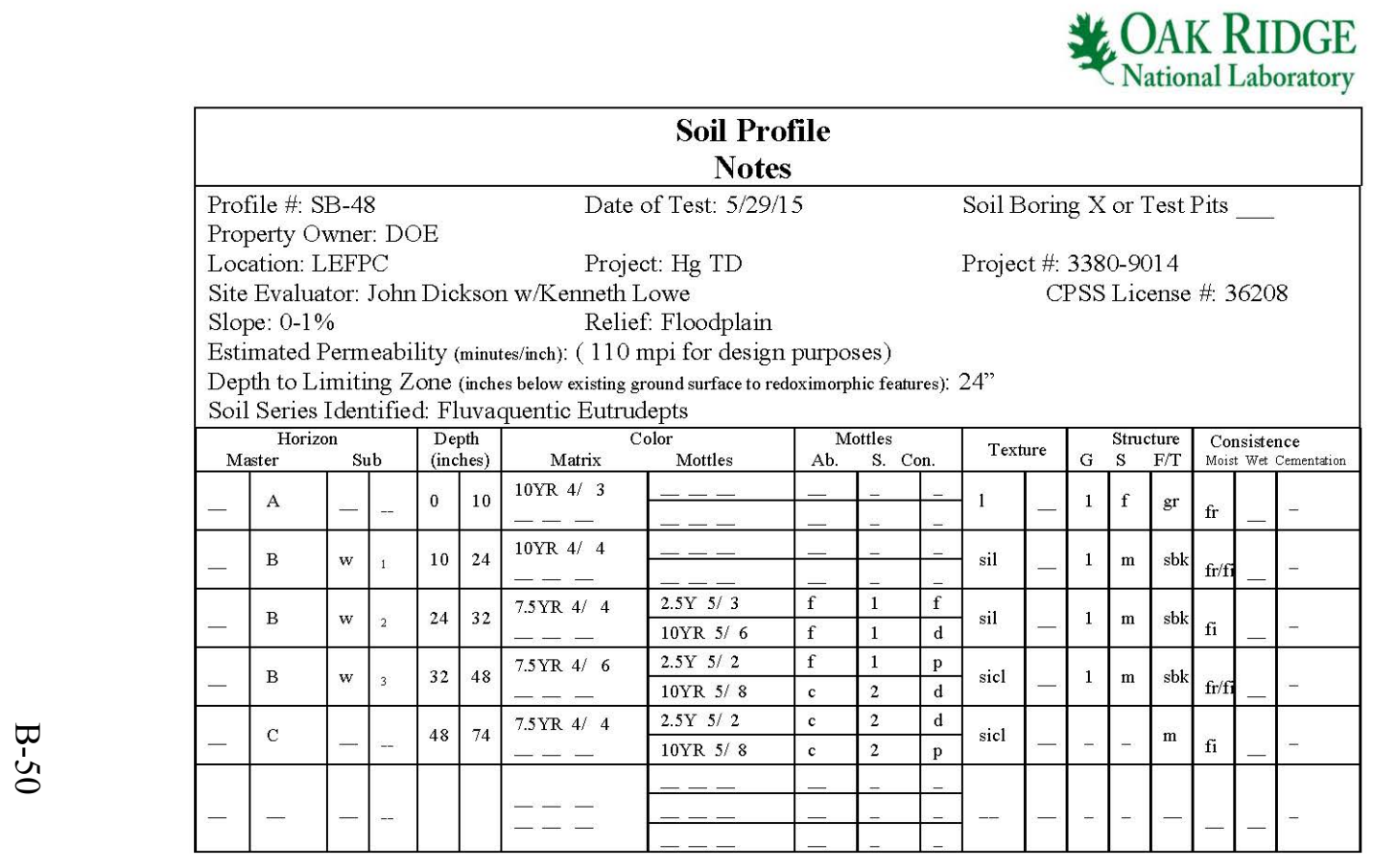

Comments:

GPS Coordinate: N: $35.97793 ; \mathrm{W}:-84.33270$

The entire soil profile appears to be firm throughout

Depth to water surface in creek: $\sim 74^{\prime \prime}$ from top of bank.

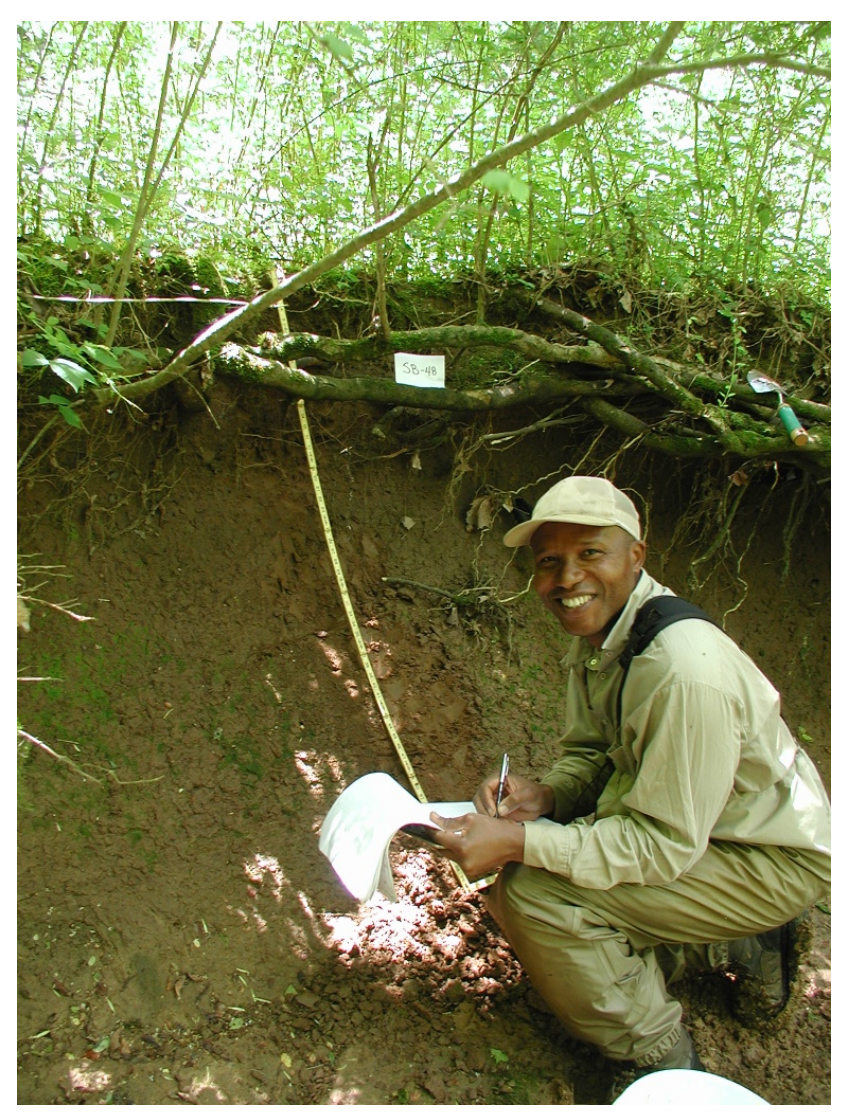




Soil Profile
Notes

Comments:

GPS Coordinate: N: 35.97694 ; W: -84.33470

At 24-36" inclusions of silty clay loam

At $54-62$ " very firm gleyed clay

Depth to water surface in creek: $\sim 62$ " from top of bank.

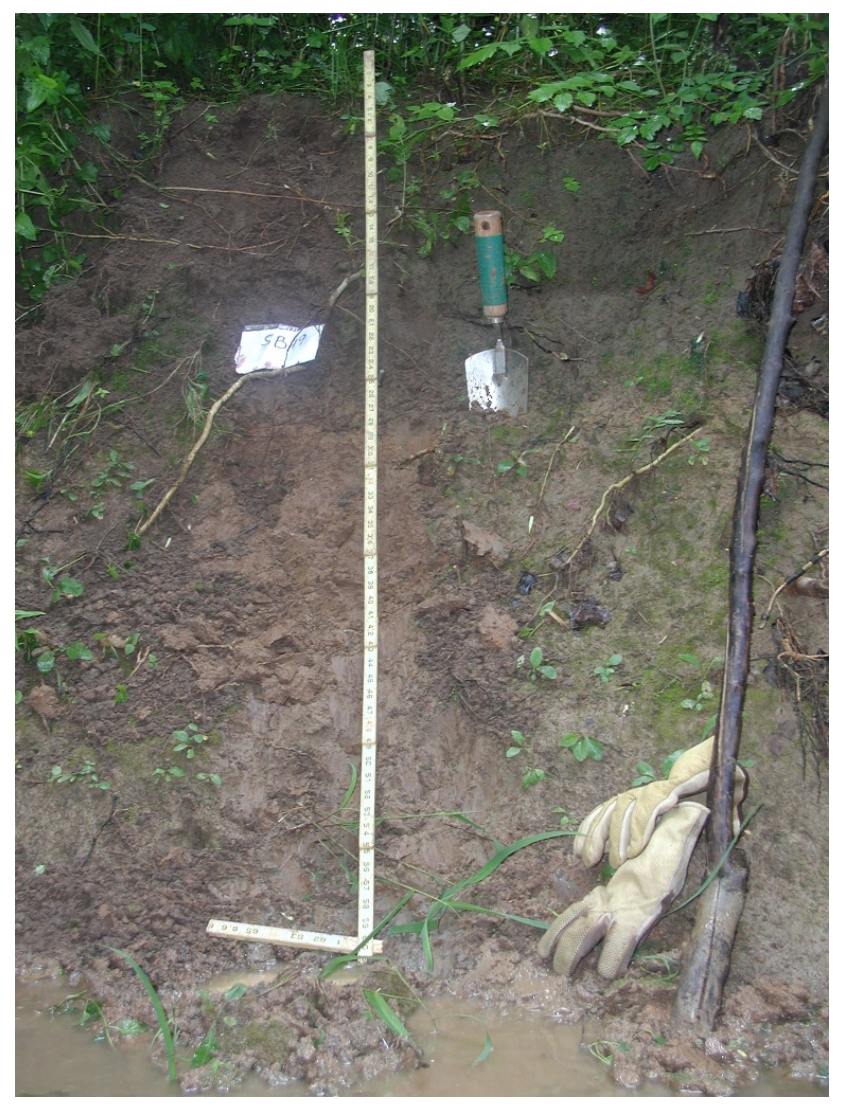




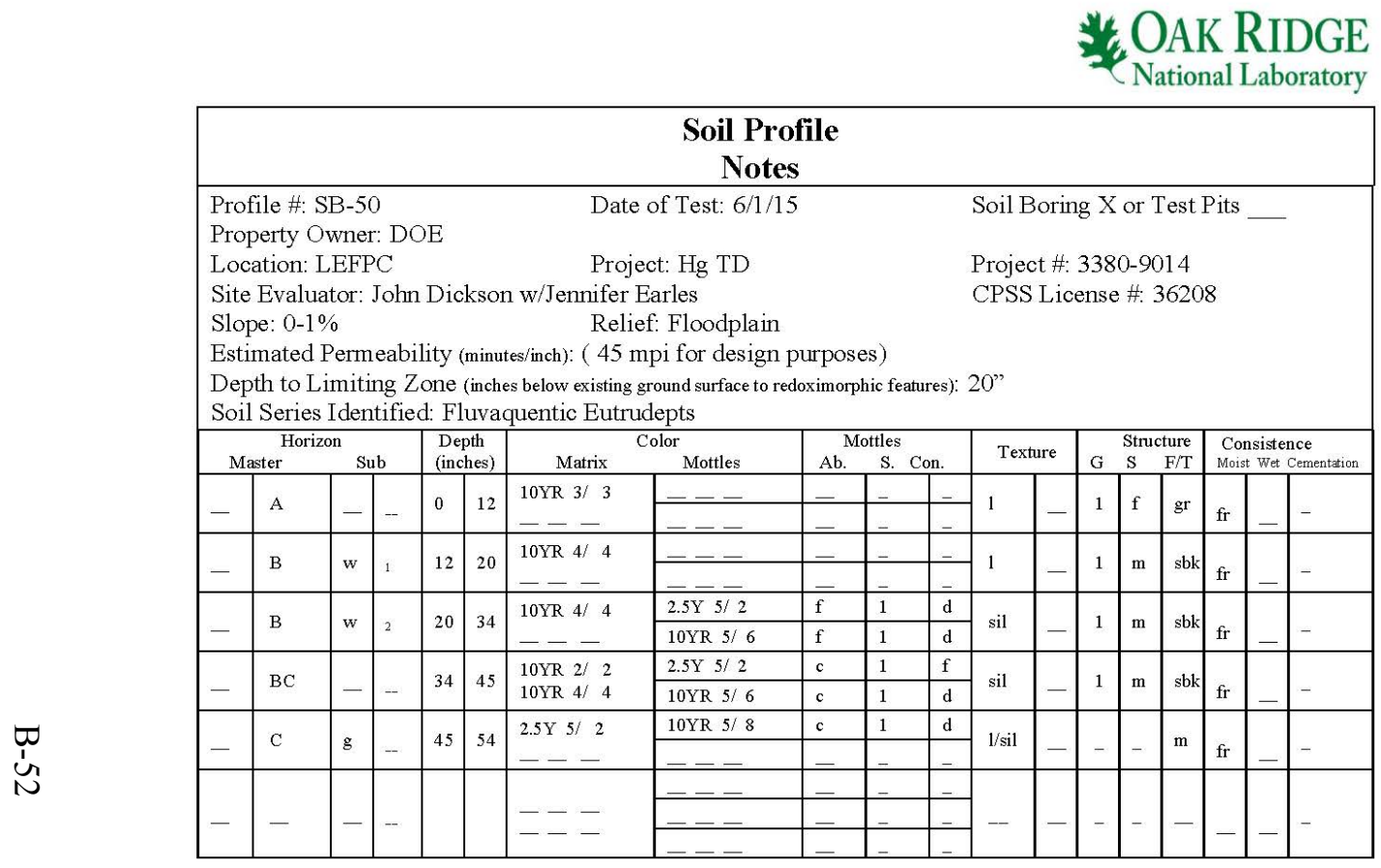

Comments:

GPS Coordinate: N: $35.97560 ; \mathrm{W}:-84.33669$

Depth to water surface in creek: 54 " from top of bank.

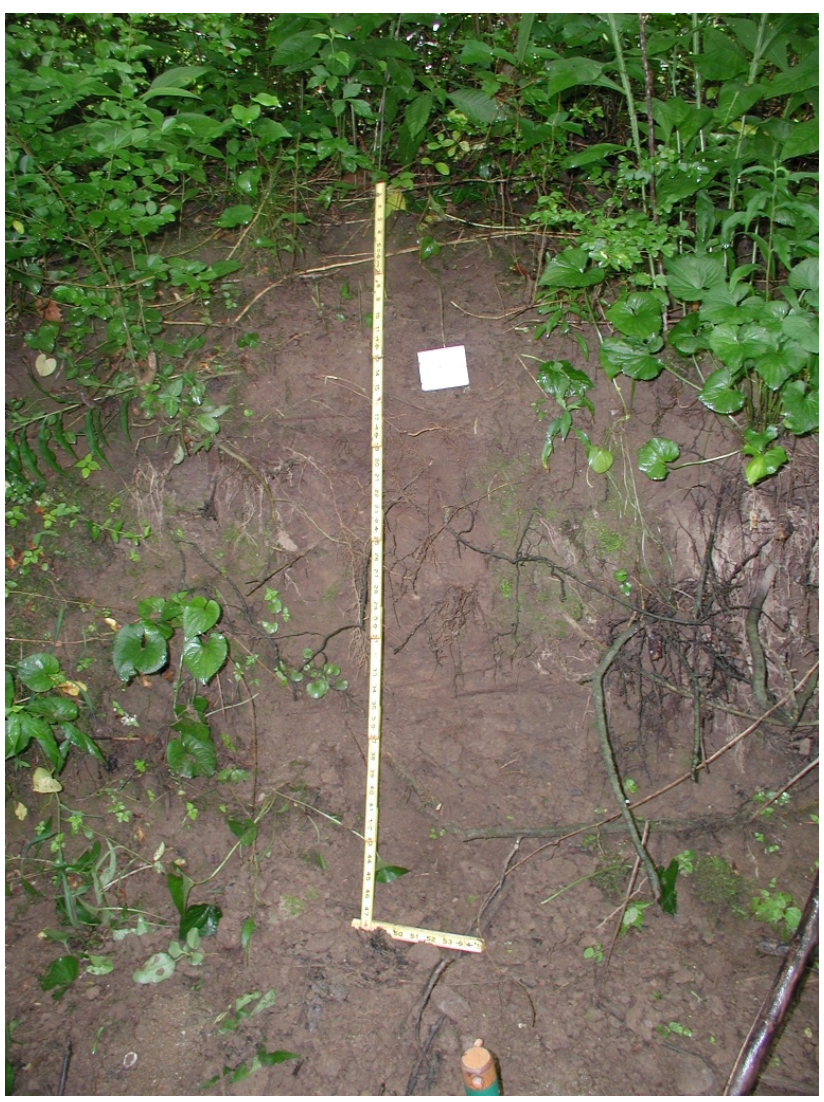




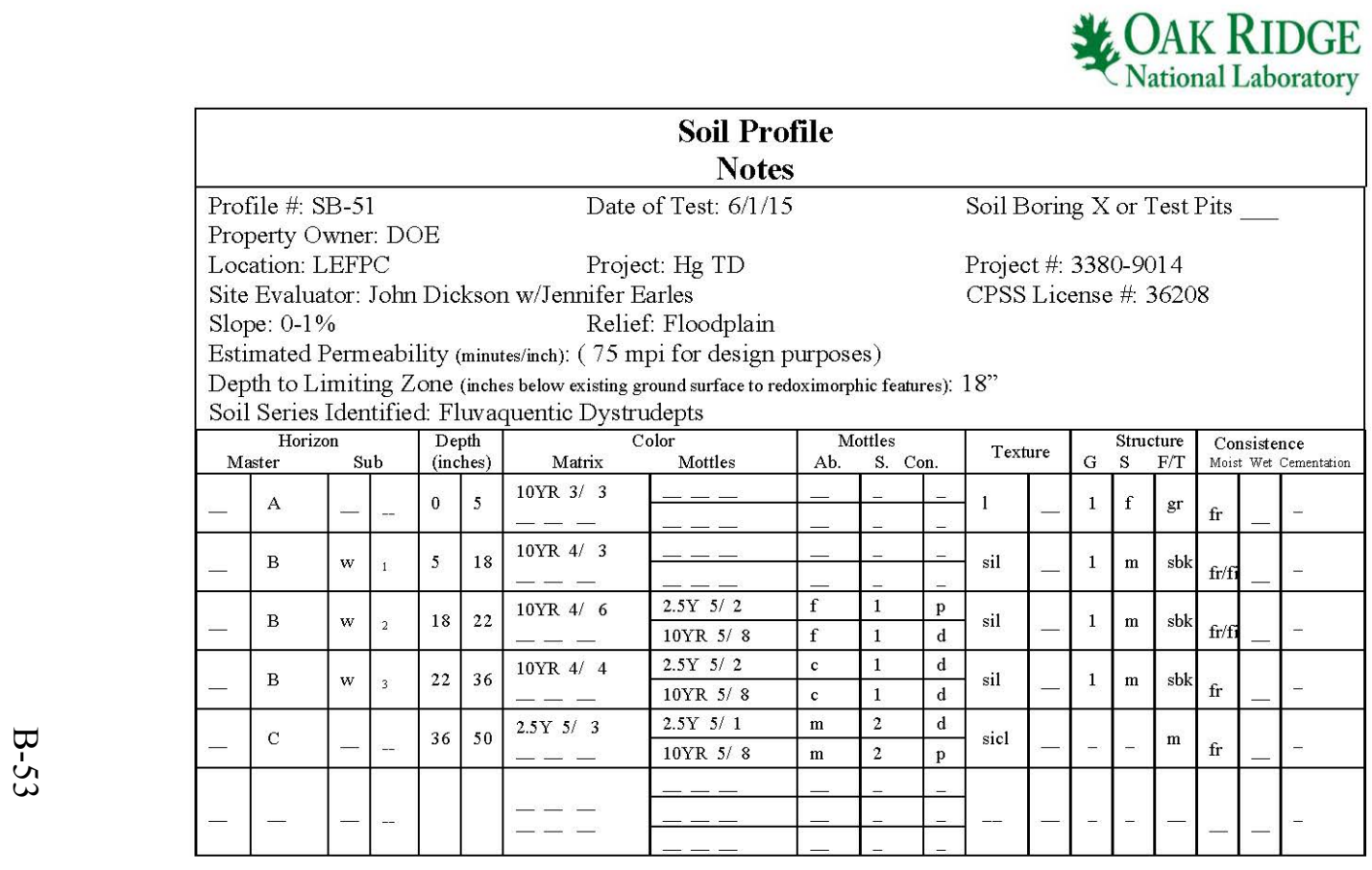

Comments:

GPS Coordinate: N: $35.97334 ; \mathrm{W}:-84.33720$

At $36-50$ " inclusions of lenses of gravels, $\sim 2 \%$ of $\mathrm{C}$ horizon At 50 " very firm clay

Depth to water surface in creek: $\sim 50$ " from top of bank.

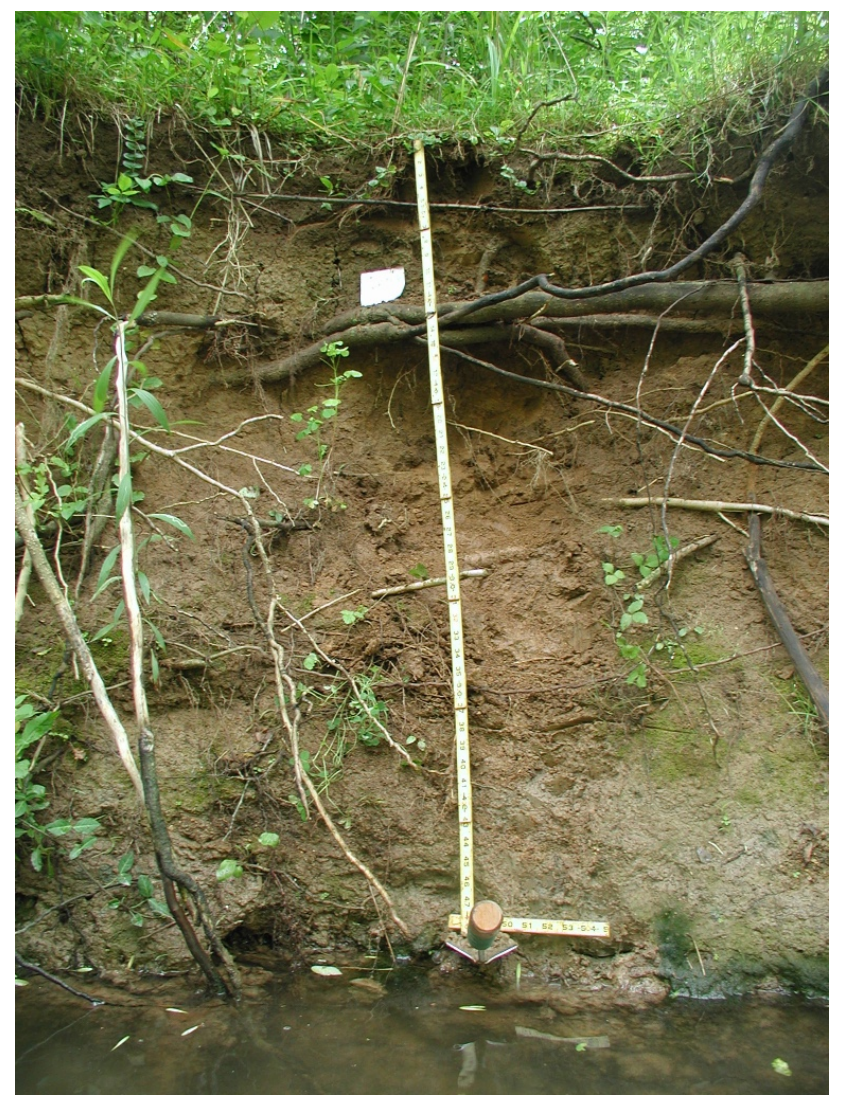




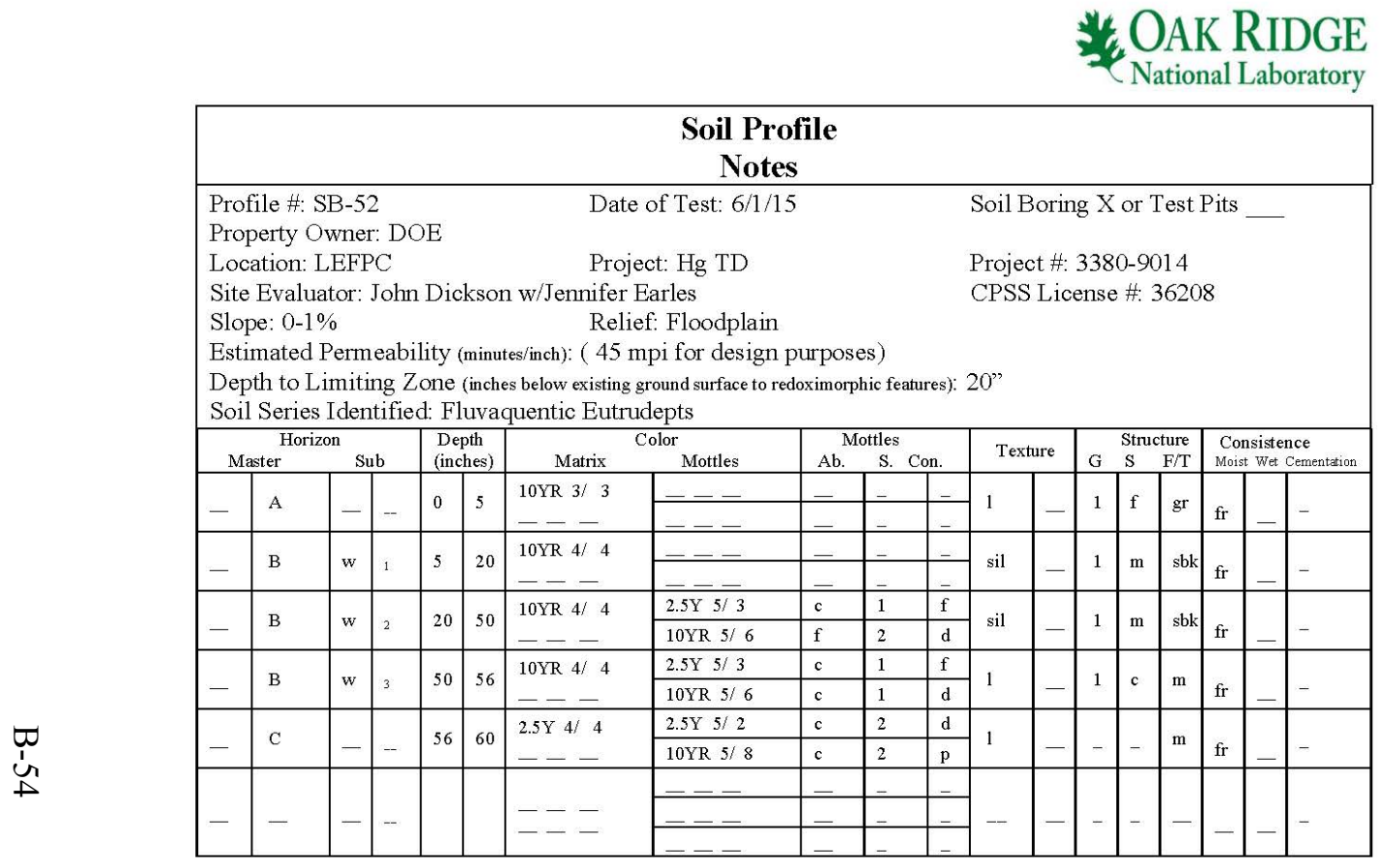

Comments:

GPS Coordinate: N: $35.97129 ;$ W: -84.33987

At 20-56" inclusions of 10YR 2/1 Mn concretions

Depth to water surface in creek: $\sim 60^{\prime \prime}$ from top of bank.

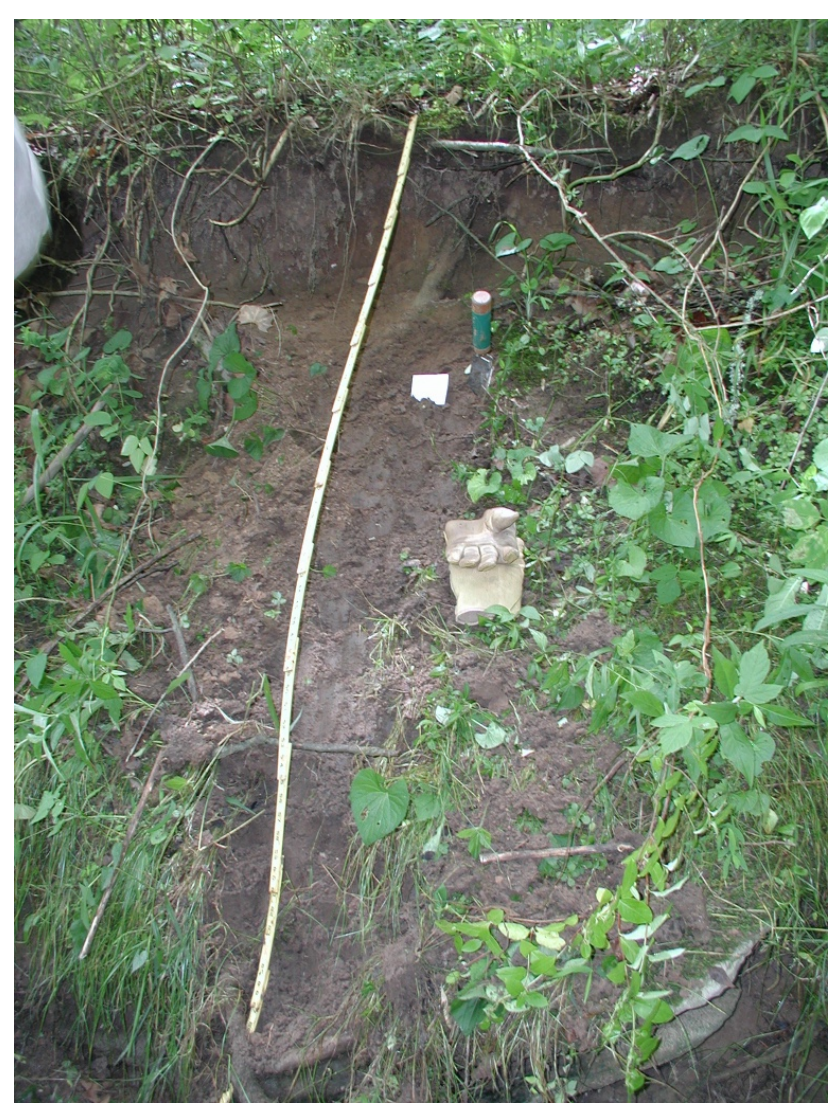




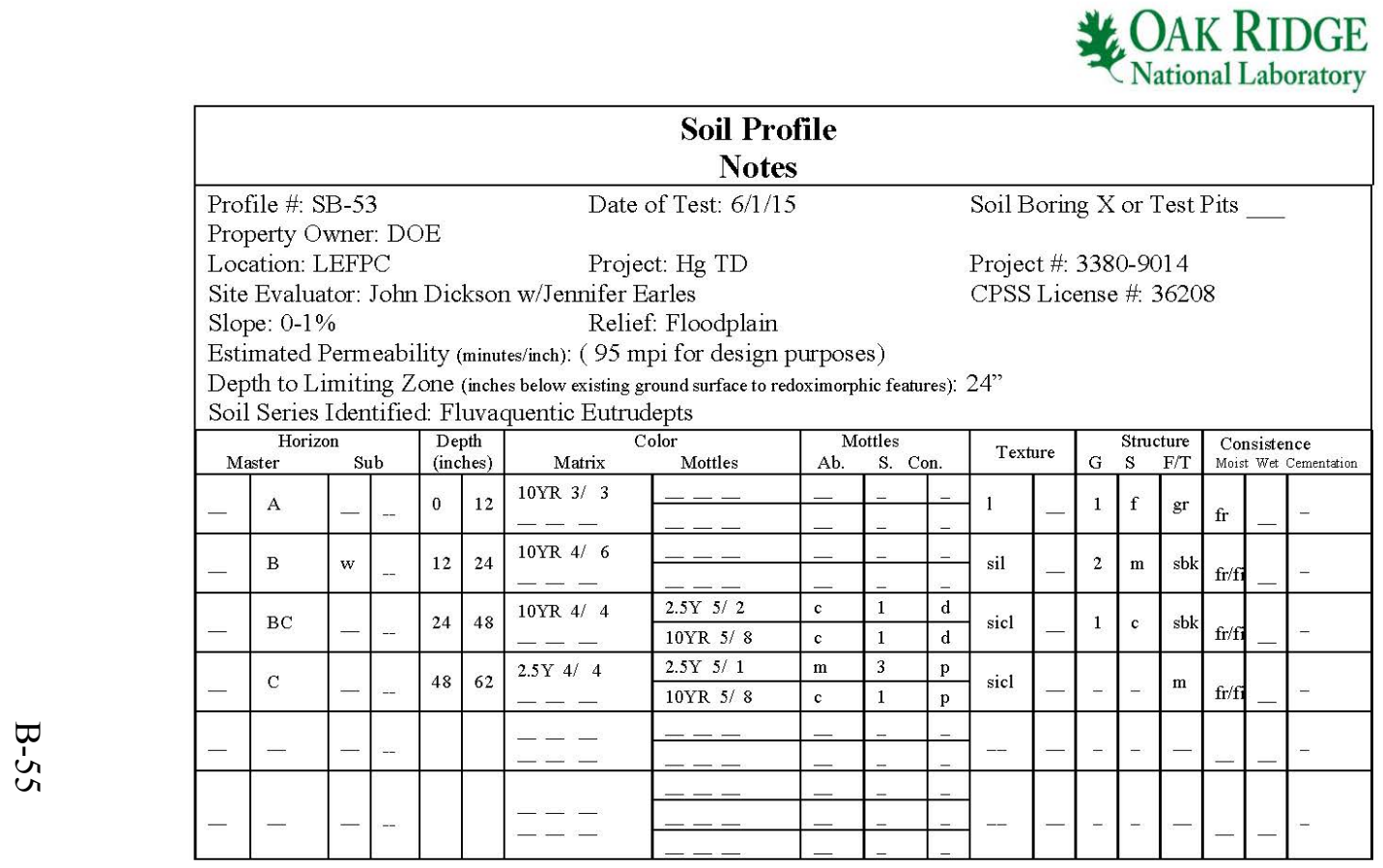

Comments:

GPS Coordinate: N: $35.97162 ; \mathrm{W}:-84.34135$

Depth to water surface in creek: $\sim 62$ " from top of bank.

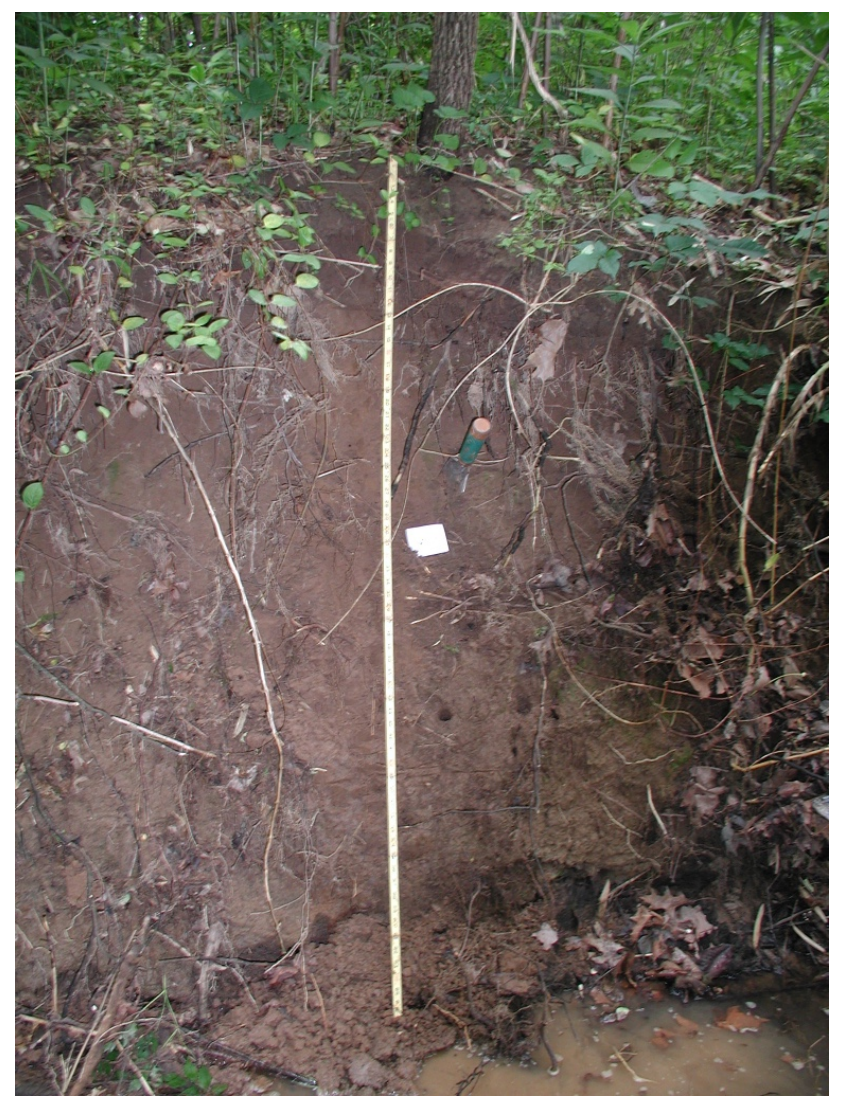

Site Evaluator's Signature 


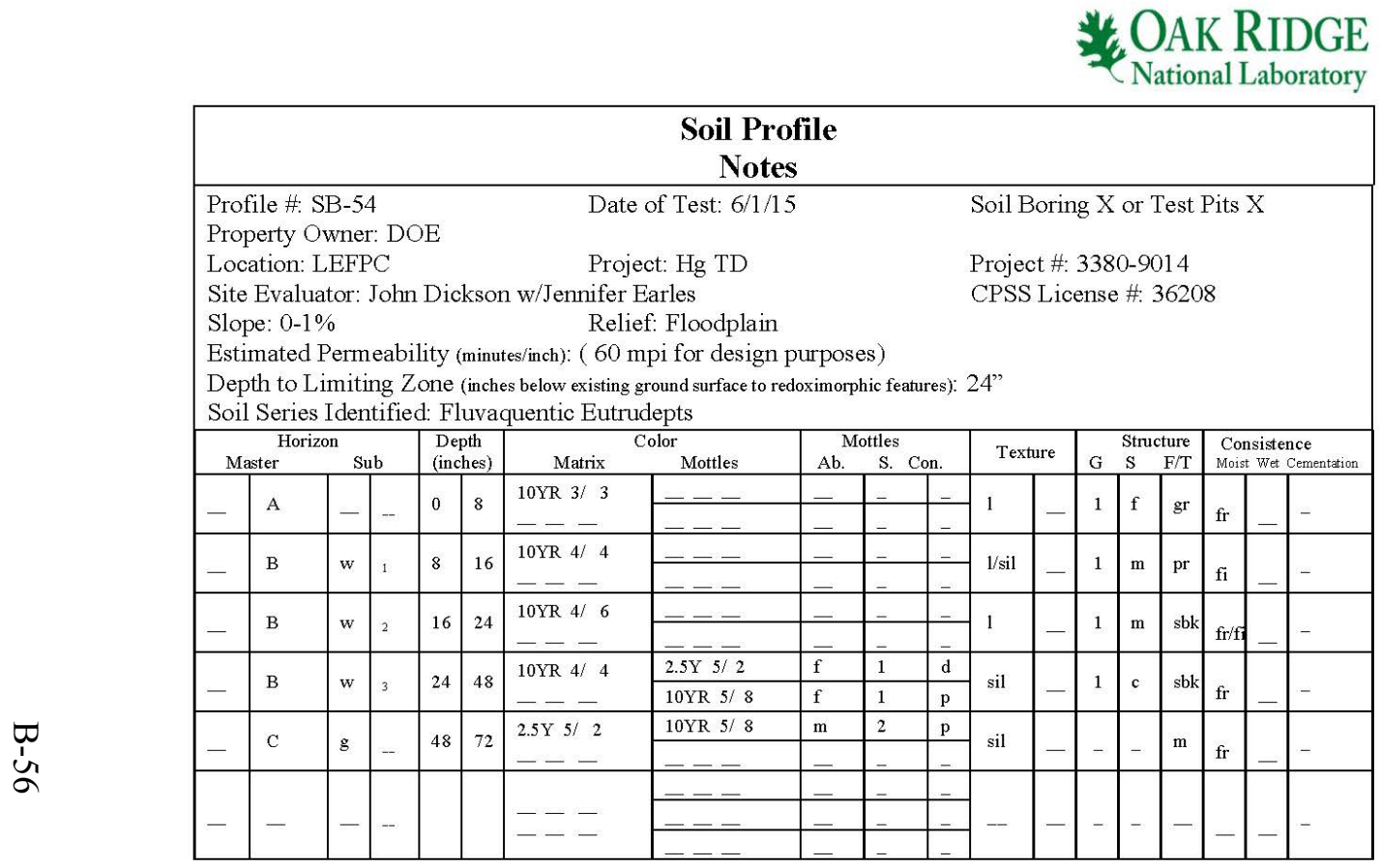

Comments:

GPS Coordinate: N: $35.96987 ; \mathrm{W}:-84.34129$

Depth to water surface in creek: $\sim 72$ " from top of bank.

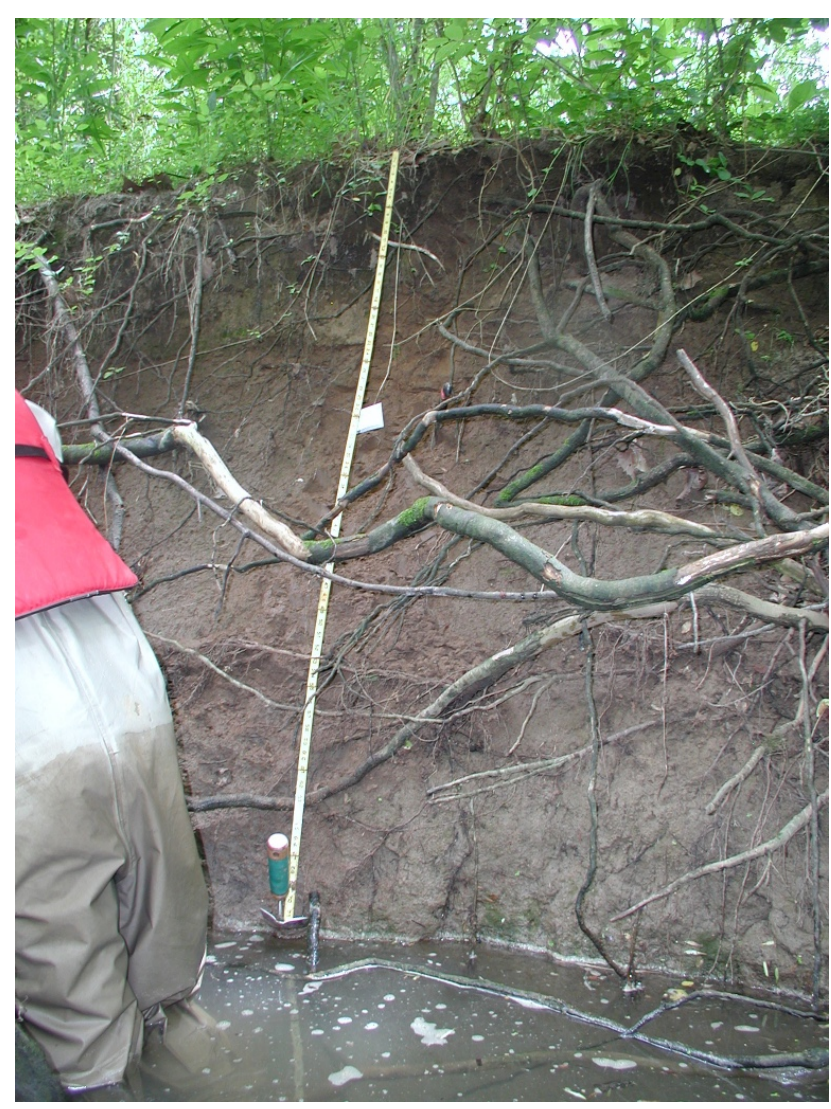




\section{OAK RIDGE}

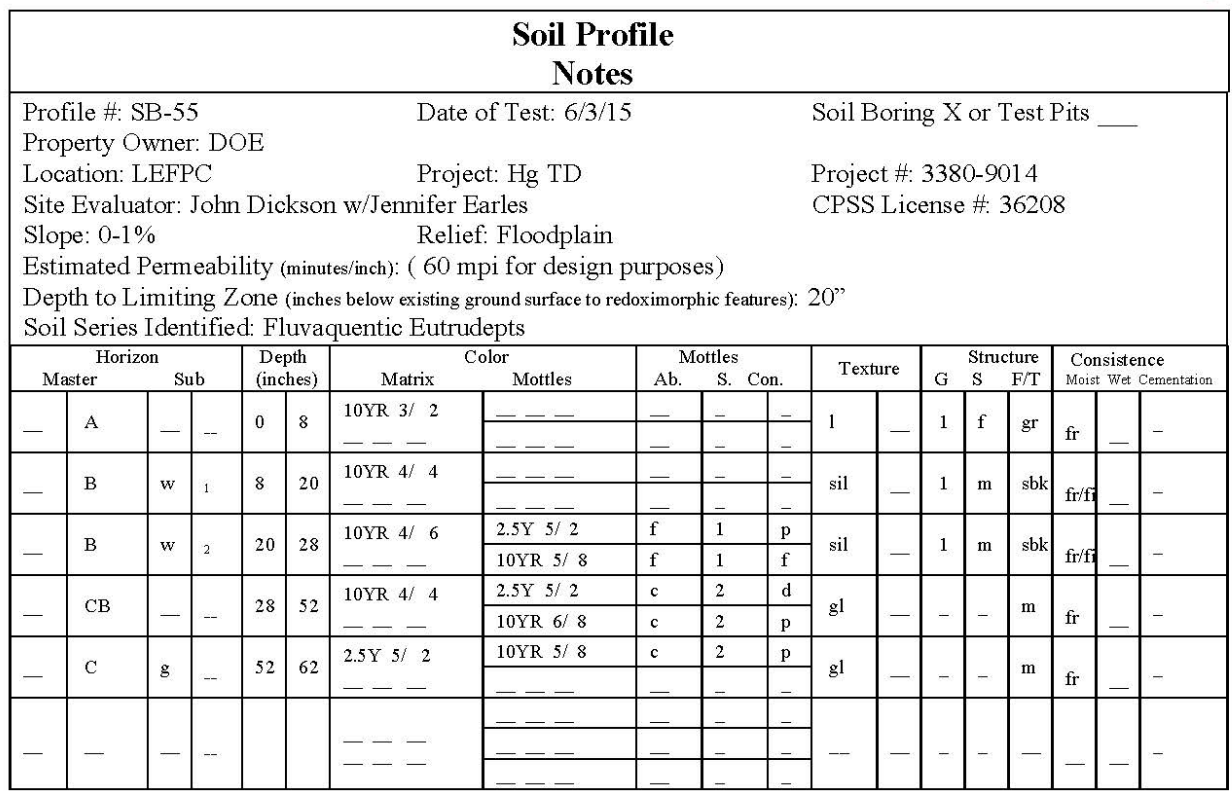

Comments:

GPS Coordinate: N: 35.96993 ; W: -84.34292

At $28-52$ " many coarse gravels (pebbles) comprising $~ 50 \%$ of horizons At 52-62" lenses of gravel

Depth to water surface in creek: $\sim 62^{\prime \prime}$ from top of bank

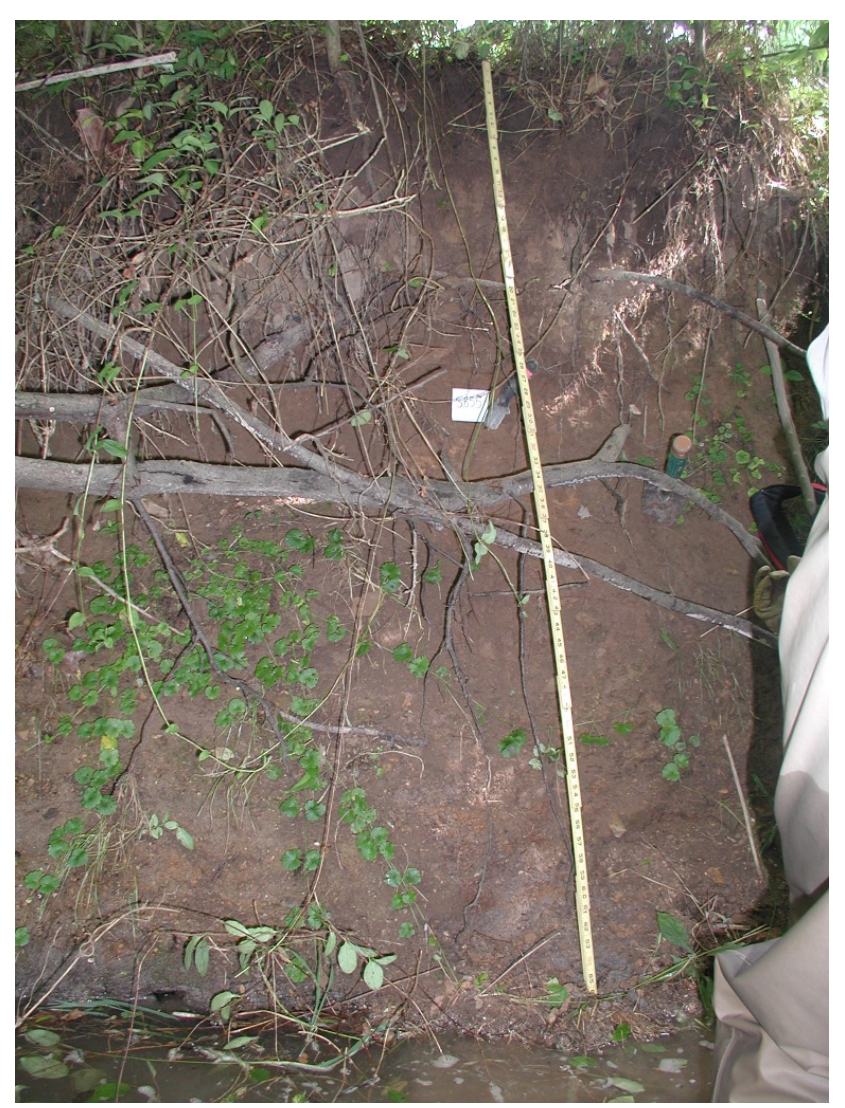

Site Evaluator's Signature 


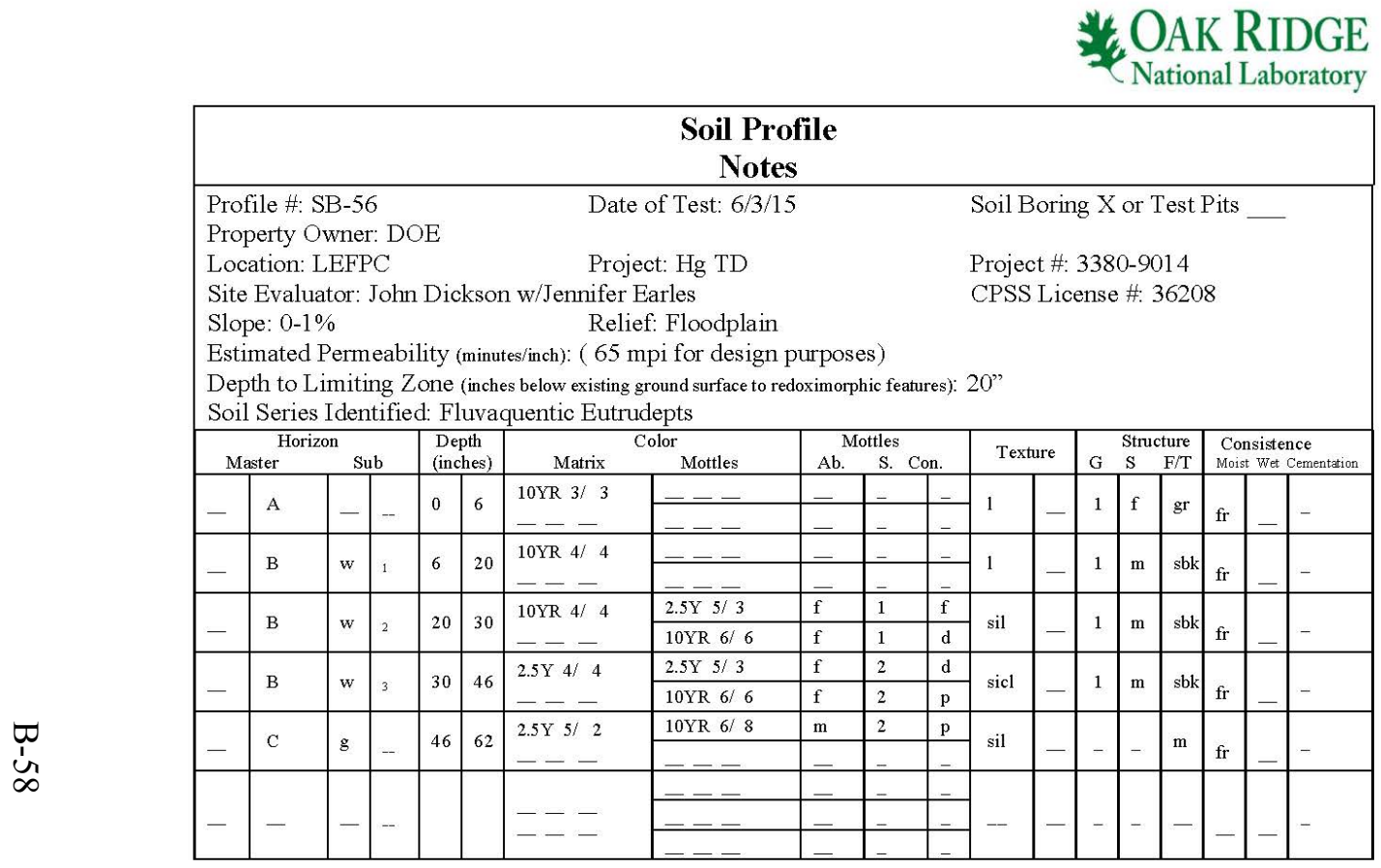

Comments:

GPS Coordinate: N: $35.96962 ; \mathrm{W}:-84.34557$

Below 62" firm gleyed clay layer

Depth to water surface in creek: $\sim 62 "$ from top of bank.

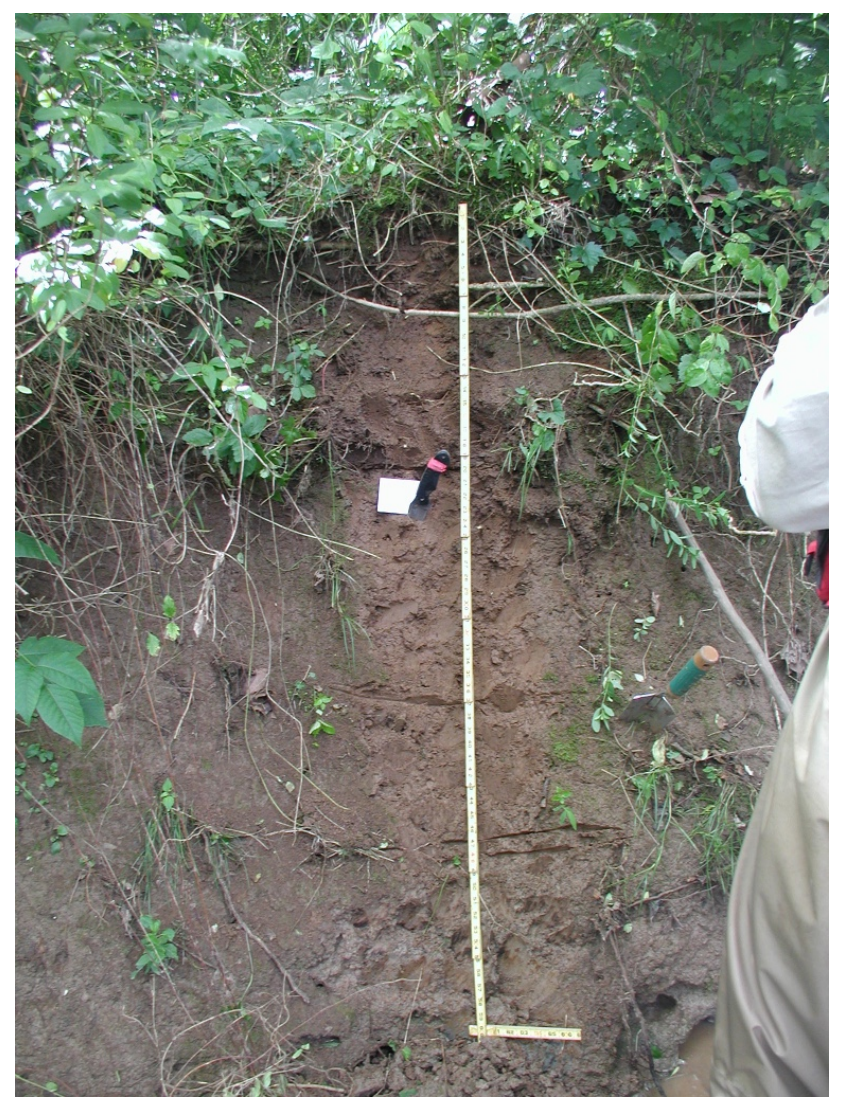




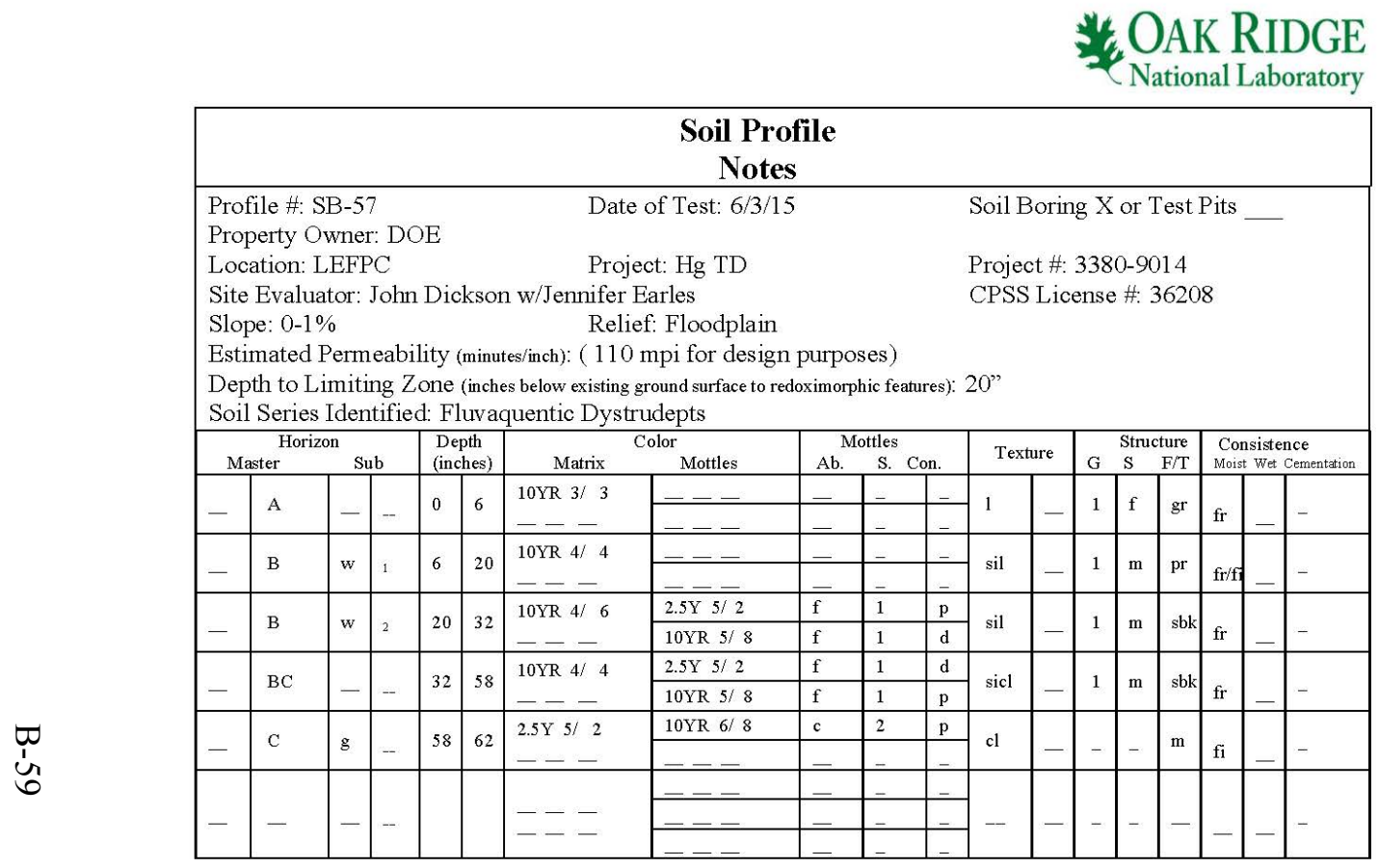

Comments:

GPS Coordinate: N: 35.97066 ; W: -84.34676

At $12-20$ " inclusion of gravels/pebbles comprising $~ 5-15 \%$ of horizon in places At 32-58" inclusion of 10YR 2/1 Mn concretions

Depth to water surface in creek: $\sim 62$ " from top of bank.

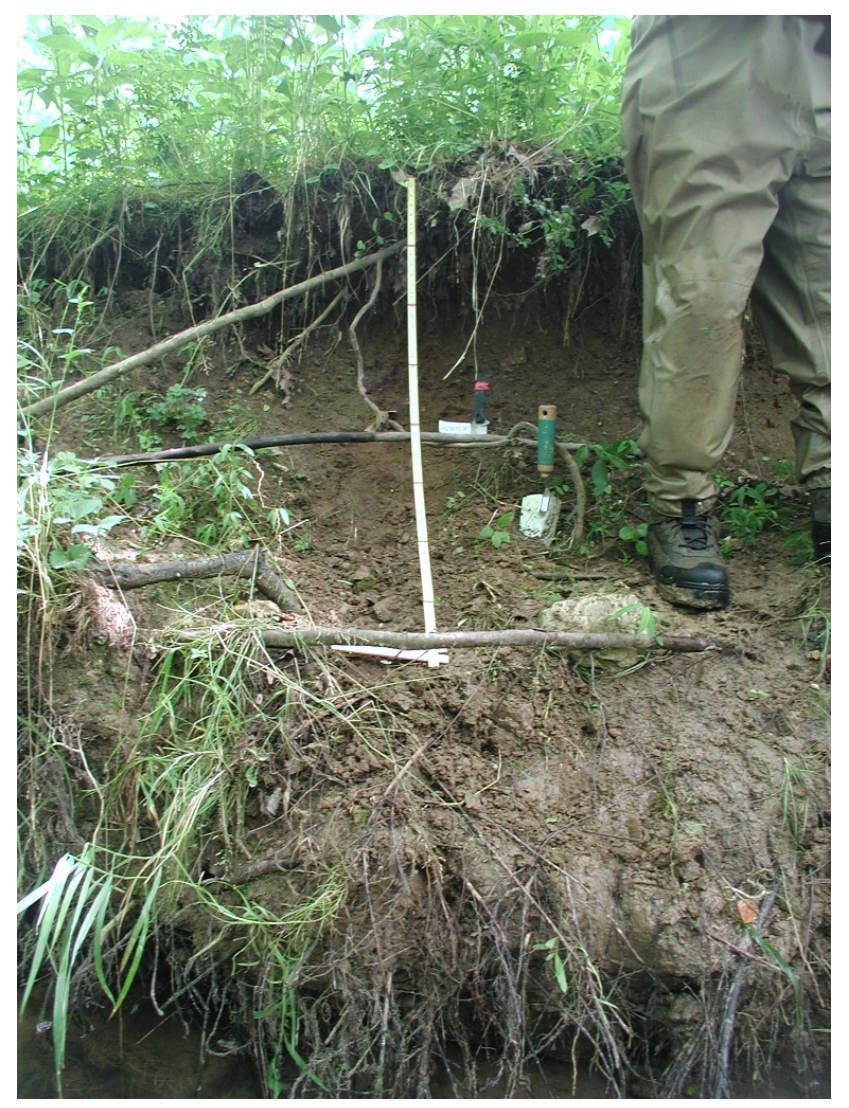


OAK RIDGE

\begin{tabular}{|c|c|c|c|c|c|c|c|c|c|c|c|c|c|c|c|c|c|c|}
\hline \multicolumn{19}{|c|}{$\begin{array}{c}\text { Soil Profille } \\
\text { Notes }\end{array}$} \\
\hline & $\begin{array}{l}\text { ile } \\
\text { erty } \\
\text { tioi } \\
\text { Eva } \\
\text { e: } \\
\text { nate } \\
\text { th to } \\
\text { Ser }\end{array}$ & $\begin{array}{l}\text { B-5 } \\
\text { Whe } \\
\text { EFl } \\
\text { tor: } \\
6 \\
\text { erm } \\
\text { mit } \\
\text { Ider }\end{array}$ & $\begin{array}{l}\text { : } \\
\text { C } \\
\text { Joh } \\
\text { eab } \\
\text { ng ? } \\
\text { tifie }\end{array}$ & $\begin{array}{l}\mathrm{E} \\
\mathrm{Di}\end{array}$ & $\begin{array}{l}\text { (minu } \\
\text { (inch } \\
\text { luva }\end{array}$ & $\begin{array}{r}\text { Dat } \\
\text { Pro } \\
\text { w/Jennifel } \\
\text { Rel } \\
\text { es/inch): ( } 60 \\
\text { s below existin } \\
\text { juentic Dys }\end{array}$ & $\begin{array}{l}\text { t: Hg TD } \\
\text { arles } \\
\text { Floodplain } \\
\text { pi for design } \\
\text { ound surface to re } \\
\text { Idepts }\end{array}$ & $\begin{array}{l}\text { urpos } \\
\text { oximor }\end{array}$ & $\begin{array}{l}\text { 8) } \\
\text { ic fea }\end{array}$ & ires): & $\begin{array}{l}\text { Soil } \\
\text { Proje } \\
\text { CPS }\end{array}$ & $\begin{array}{l}\text { ct \#: } \\
\text { Lice }\end{array}$ & $\begin{array}{l}338 \\
\text { ens }\end{array}$ & $0-90$ & 3620 & its & & \\
\hline \multicolumn{4}{|c|}{\begin{tabular}{ll}
\multicolumn{1}{c}{ Horizon } \\
Master & Sub \\
\end{tabular}} & \multicolumn{2}{|c|}{$\begin{array}{l}\begin{array}{c}\text { Depth } \\
\text { (inches) }\end{array} \\
\end{array}$} & \multicolumn{2}{|c|}{ Matrix ${ }_{\text {Mottles }}^{\text {Color }}$} & \multicolumn{3}{|c|}{ Mottles } & \multicolumn{2}{|c|}{ Texture } & \multicolumn{3}{|c|}{$\begin{array}{l}\text { Structure } \\
\mathrm{S}\end{array}$} & \multicolumn{3}{|c|}{$\begin{array}{l}\text { Consistence } \\
\text { Moist Wret Cementation }\end{array}$} \\
\hline- & A & - & -- & 0 & 7 & $\begin{array}{l}10 \mathrm{YR} 3 / 3 \\
---\end{array}$ & \begin{tabular}{|l|}
$-\ldots-$ \\
$-\ldots-$
\end{tabular} & - & $x_{0}$ & - & 1 & - & 1 & $f$ & $\mathrm{gr}$ & $\mathrm{fr}$ & & - \\
\hline- & B & $\mathrm{w}$ & 1 & 7 & 22 & $\begin{array}{l}7.5 \text { YR } 4 / 6 \\
---\end{array}$ & --- & - & - & - & sil & - & 2 & $\mathrm{~m}$ & sbk & fr & & - \\
\hline- & B & $\mathrm{w}$ & 2 & 22 & 36 & $\begin{array}{l}10 \text { YR } 4 / 4 \\
---\end{array}$ & \begin{tabular}{|l|}
$2.5 \mathrm{Y} 5 / 3$ \\
$10 \mathrm{YR} 5 / 6$ \\
\end{tabular} & $\frac{f}{f}$ & $\frac{1}{1}$ & $\begin{array}{ll}f \\
d\end{array}$ & sil & - & 1 & $\mathrm{~m}$ & sbk & $\mathrm{fr} / \mathrm{f}$ & & - \\
\hline- & C & - & - & 36 & 60 & $\begin{array}{l}2.5 \mathrm{Y} 4 / 4 \\
--- \\
\end{array}$ & \begin{tabular}{|l|}
$2.5 \mathrm{Y} 6 / 2$ \\
$10 \mathrm{YR} 5 / 6$ \\
\end{tabular} & $\begin{array}{ll}\mathrm{c} \\
\mathrm{c} \\
\end{array}$ & $\frac{2}{1}$ & $\frac{d}{d}$ & sil & - & - & - & $\mathrm{m}$ & fr & & - \\
\hline- & - & - & -- & & & $\begin{array}{l}{ }_{-1}-- \\
---\end{array}$ & \begin{tabular}{|l|}
--- \\
---
\end{tabular} & - & - & - & - & - & - & - & - & & & - \\
\hline - & - & - & -- & & & --- & & - & - & - & - & - & - & - & - & - & & - \\
\hline
\end{tabular}

Comments:

GPS Coordinate: N: 35.97077 ; W: -84.34891

At 22-36" inclusions of $\mathrm{SiL}^{+}$, and $\mathrm{SiCL}$ in places

Below 60" firm, gleyed clay horizon

Depth to water surface in creek: $\sim 60^{\prime \prime}$ from top of bank.

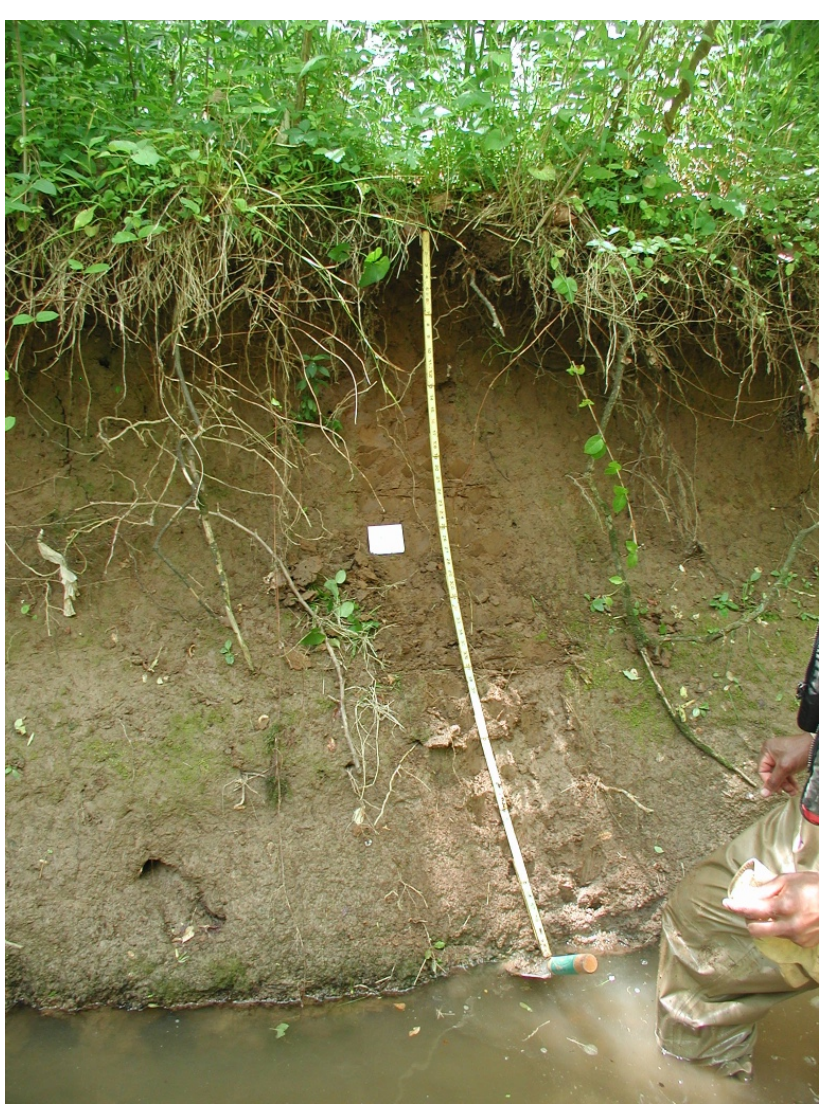




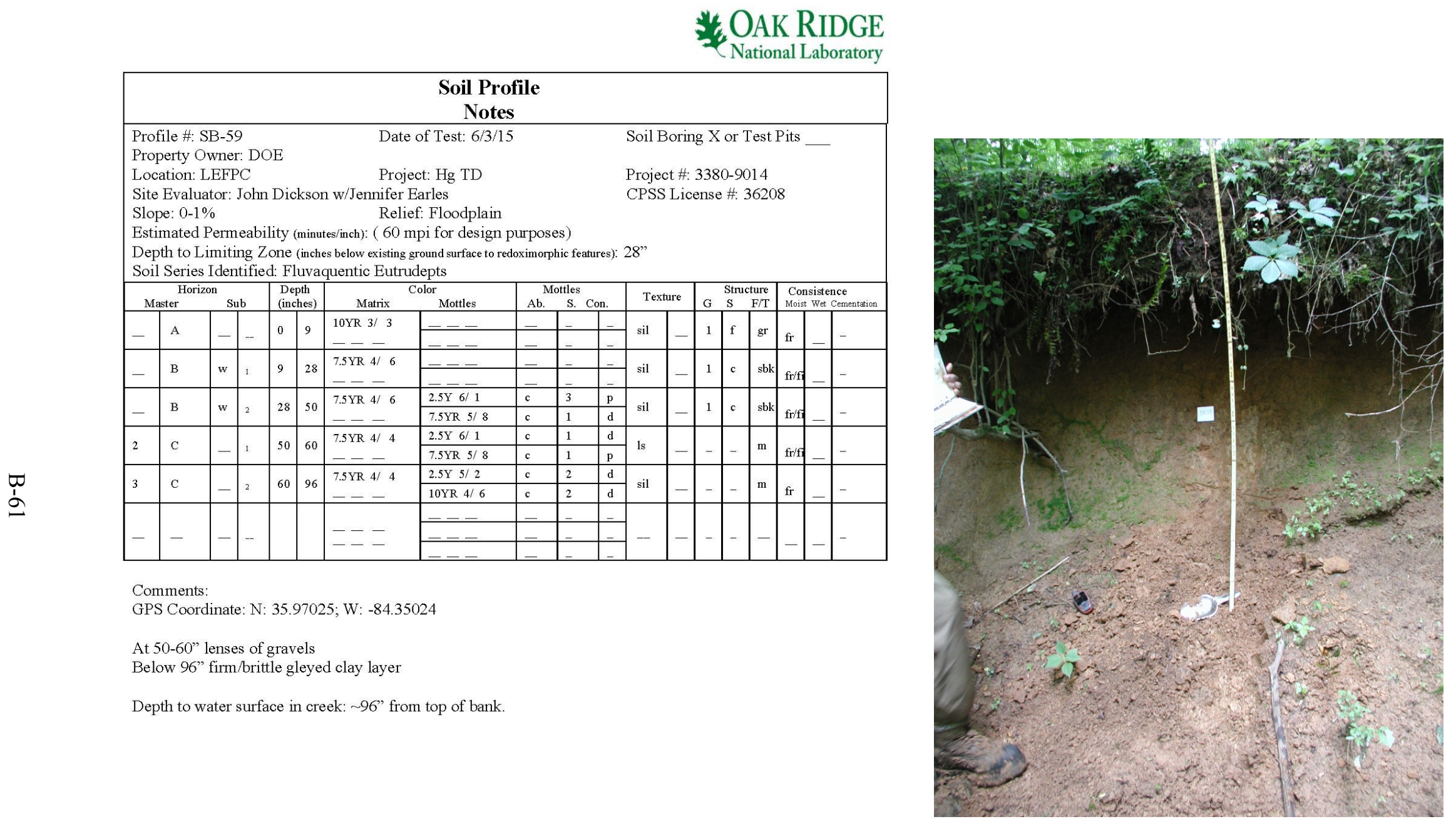




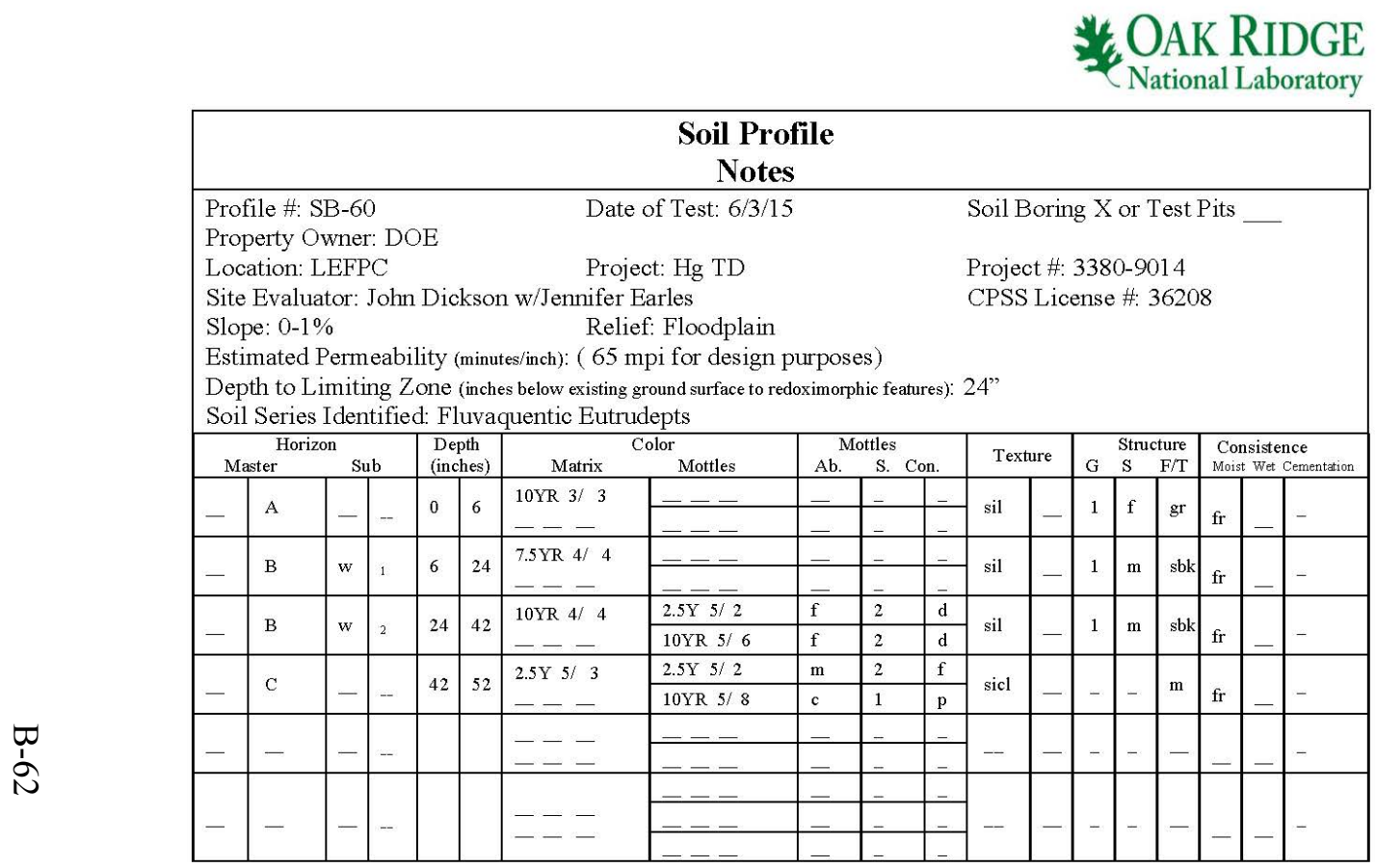

Comments:

GPS Coordinate: N: $35.96901 ; \mathrm{W}:-84.35249$

Below 52" firm gleyed clay horizon

Depth to water surface in creek: $\sim 52$ " from top of bank.

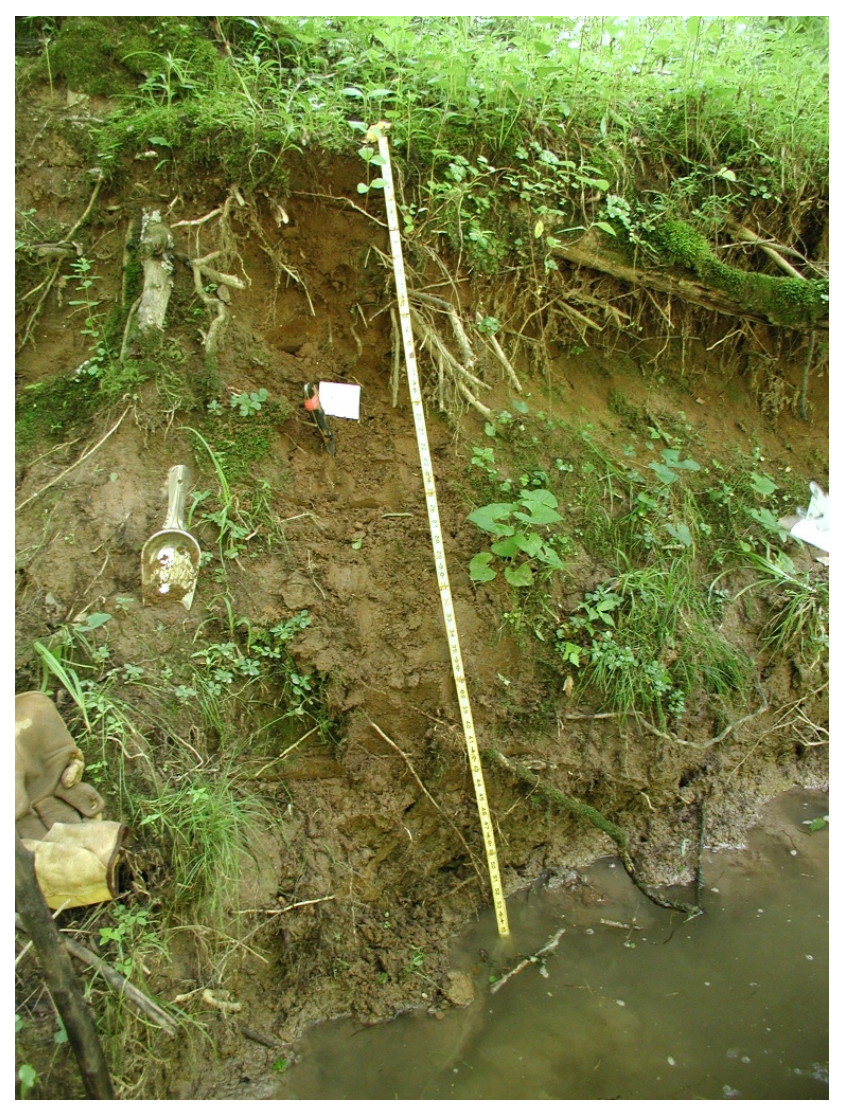




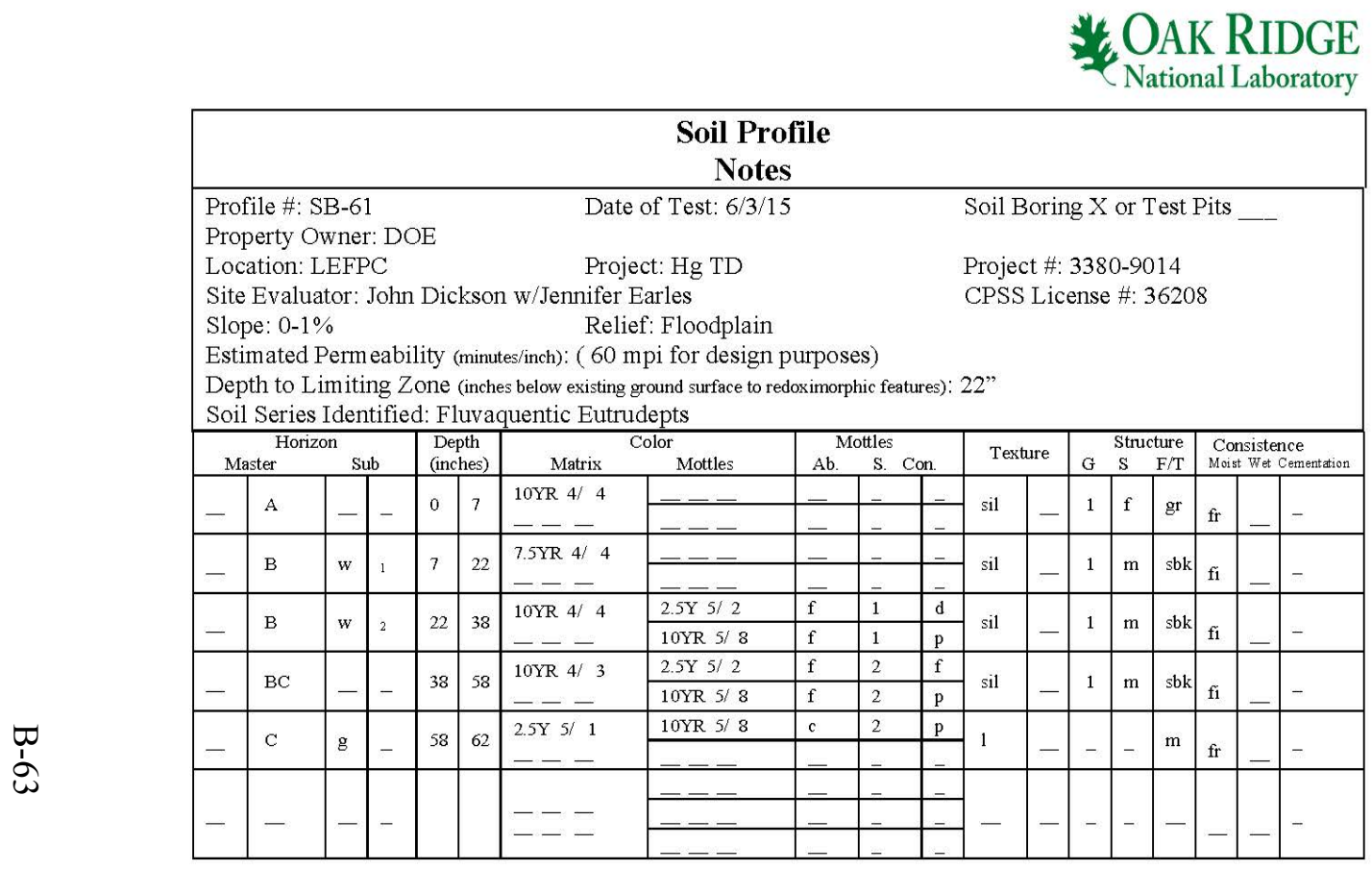

Comments:

GPS Coordinate: N: $35.96820 ; \mathrm{W}:-84.35178$

Depth to water surface in creek: $\sim 62 "$ from top of bank.

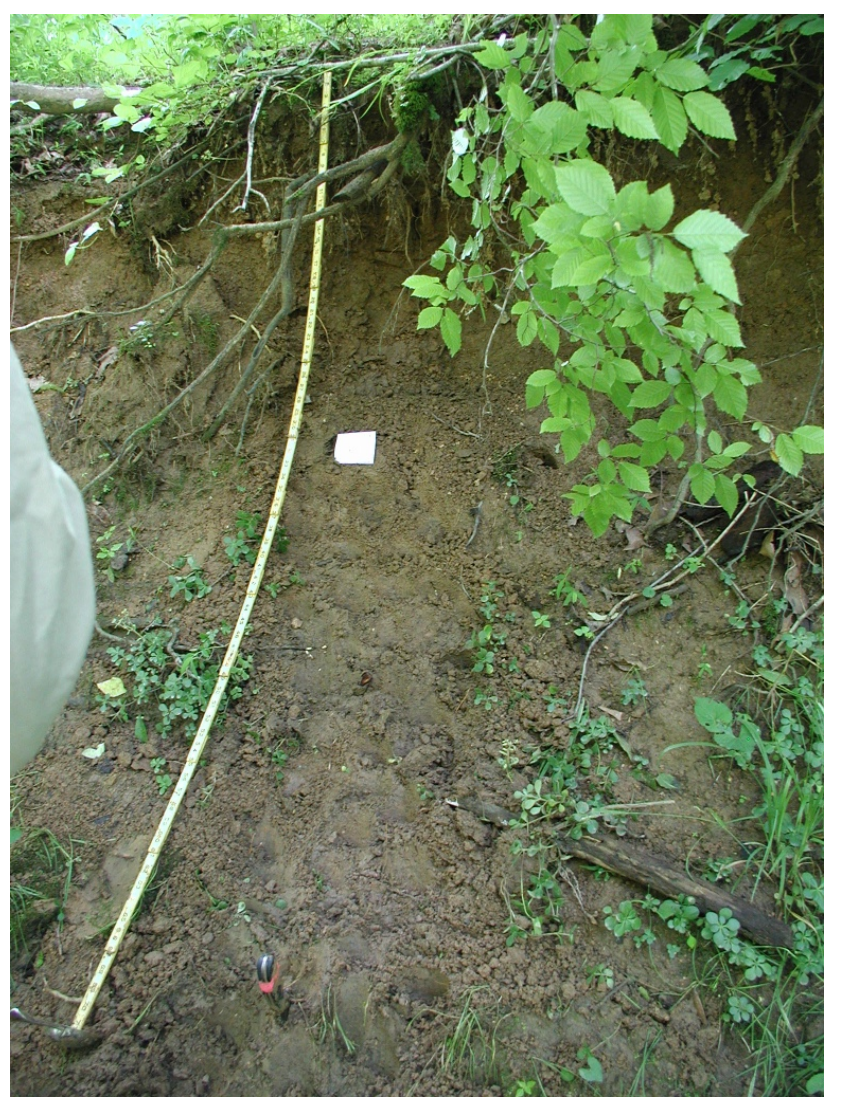




Soil Profile
Notes

Comments:

GPS Coordinate: N: 35.96772 ; W: -84.35081

Depth to water surface in creek: $\sim 96$ " from top of bank.

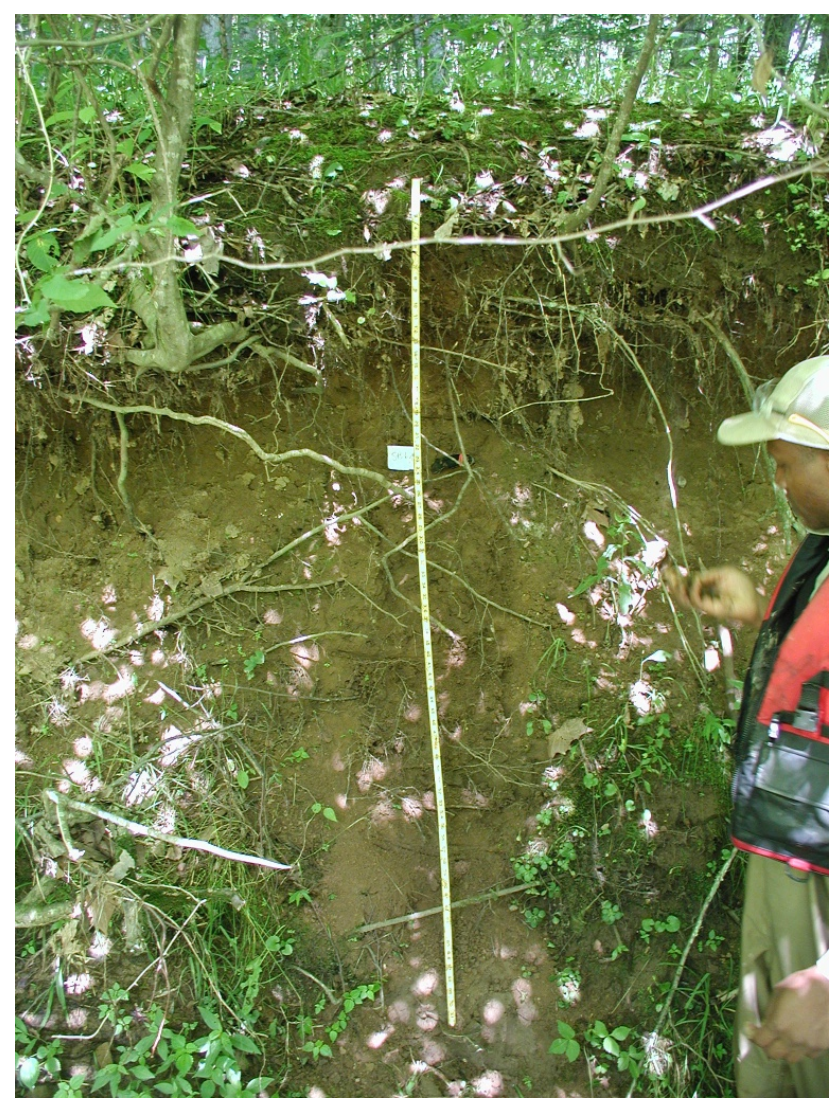




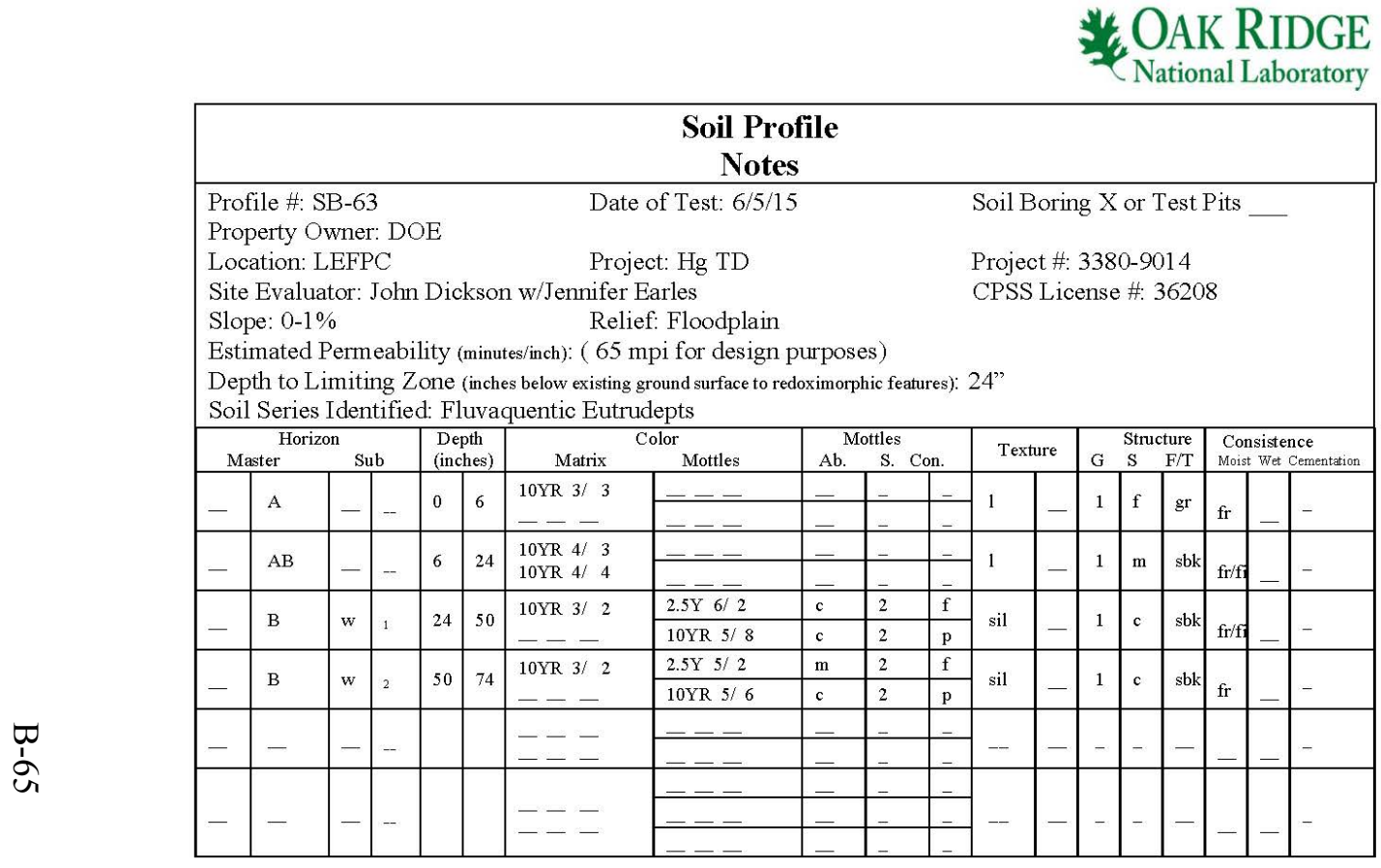

Comments:

GPS Coordinate: N: 35.96635 ; W: -84.35150

Depth to water surface in creek: 74" from top of bank.

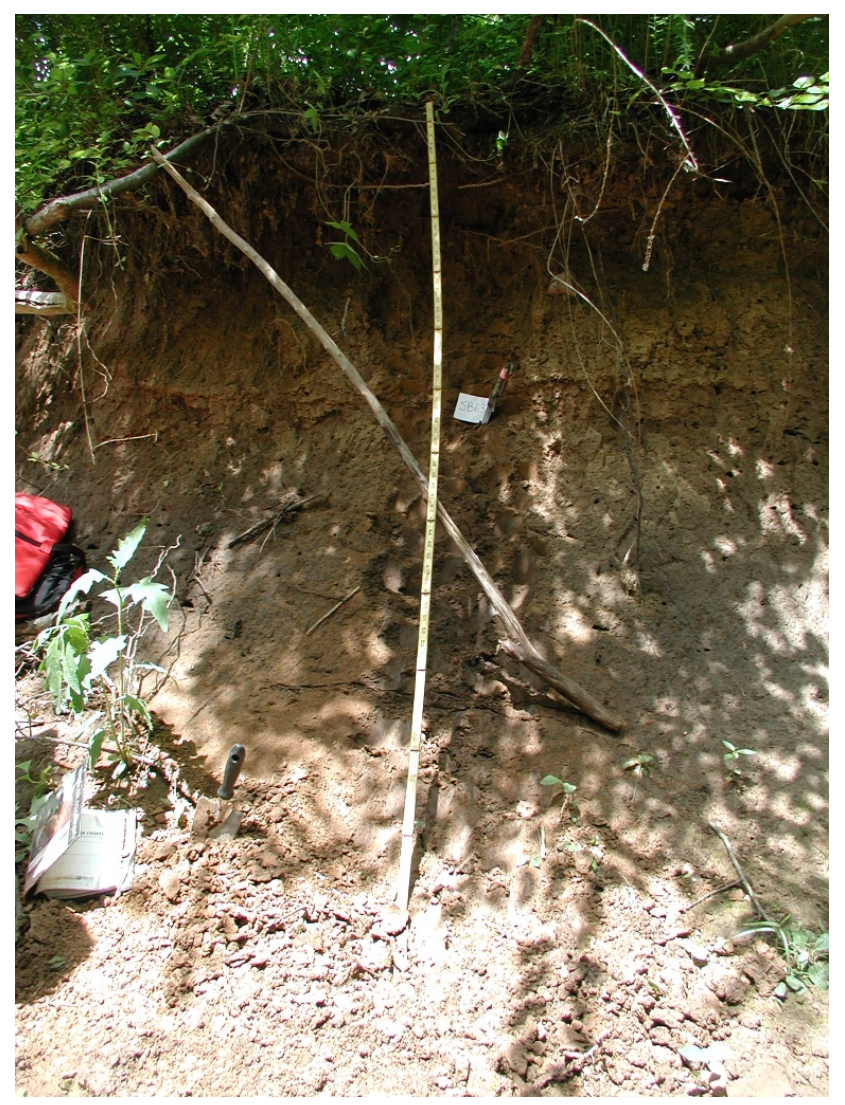




\section{OAK RIDGE}

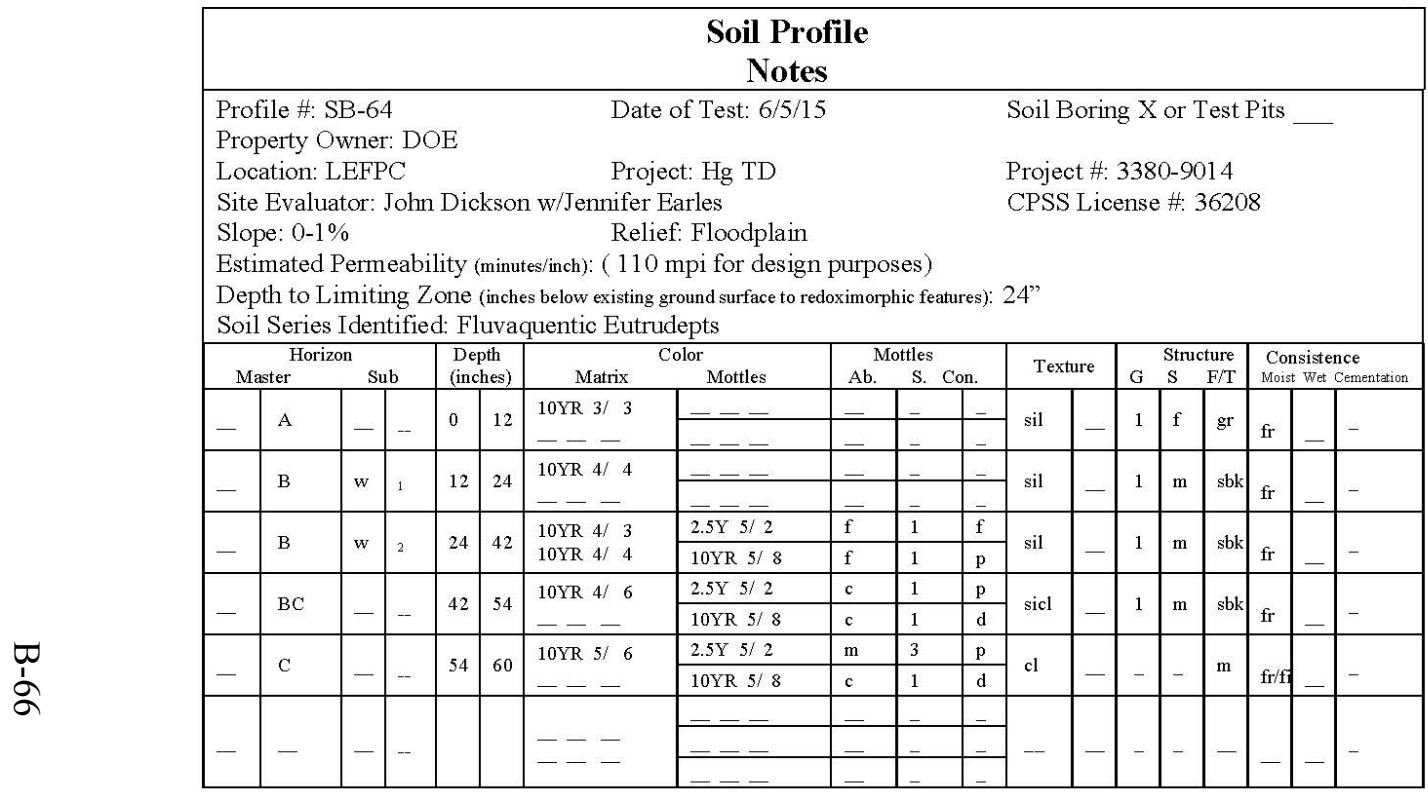

Comments:

GPS Coordinate: N: $35.96577 \cdot \mathrm{W} \cdot-84.35435$

Depth to water surface in creek: $\sim 60^{\prime \prime}$ from top of bank

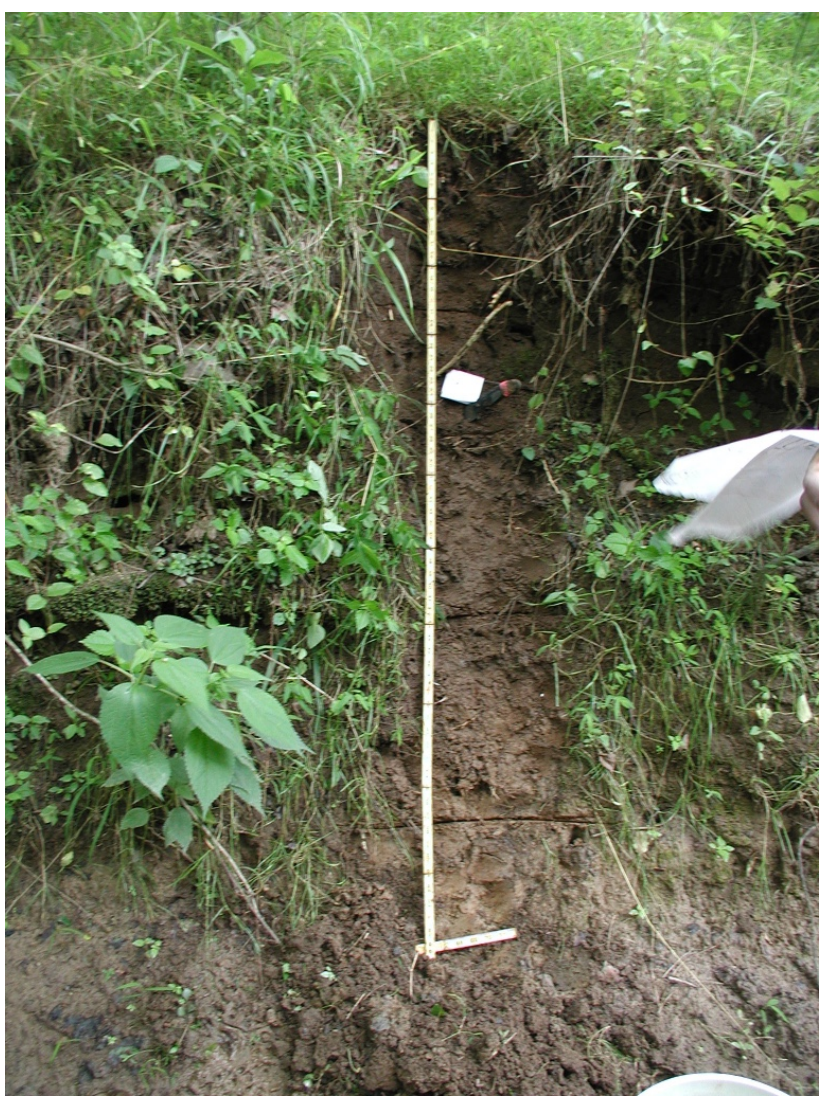




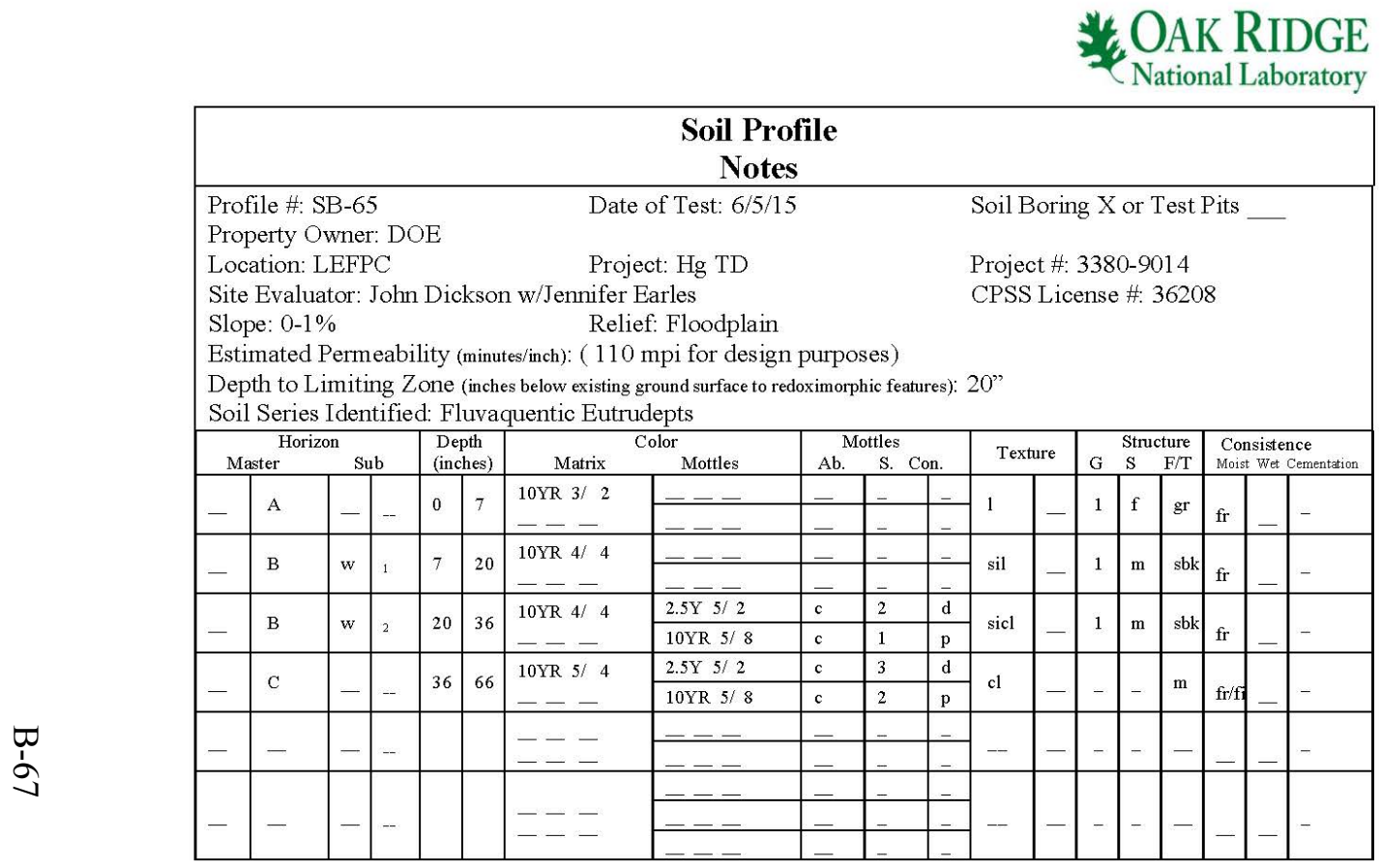

Comments:

GPS Coordinate: N: 35.96619; W: -84.35594

Depth to water surface in creek: $>66$ " from top of bank.

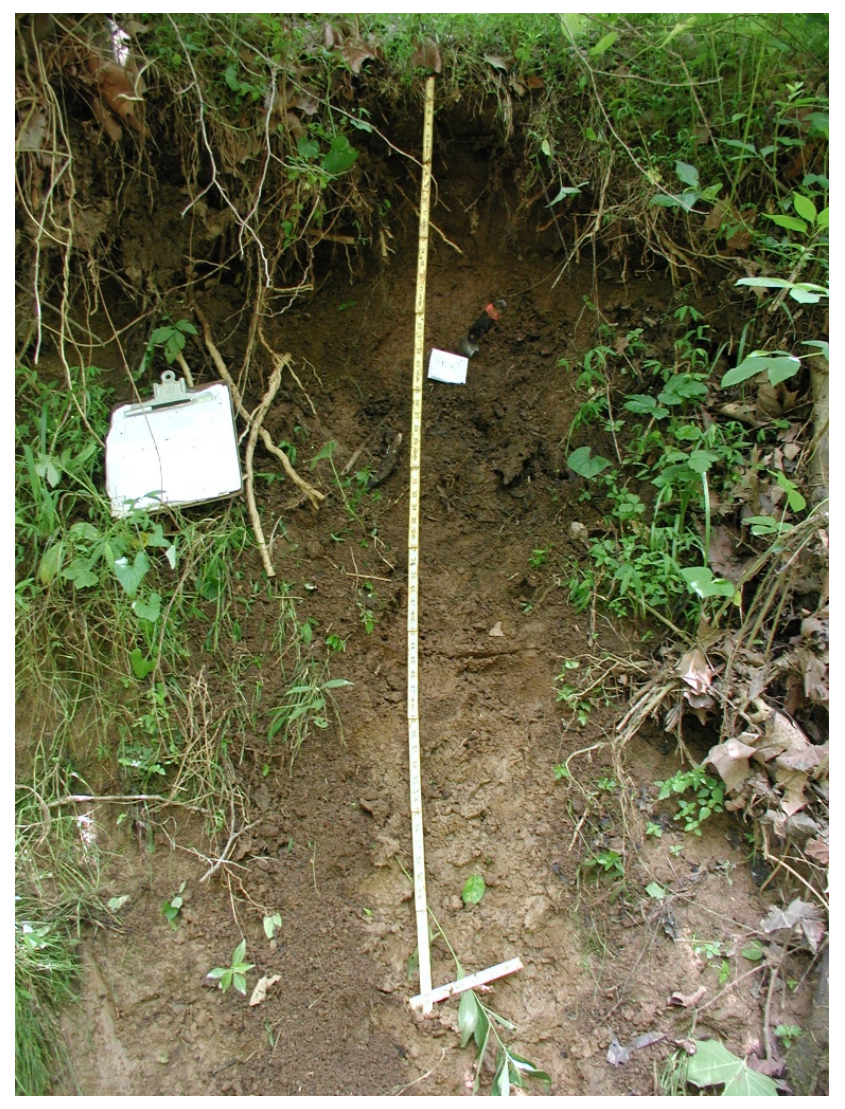




Soil Profile
Notes

Comments:

GPS Coordinate: N: 35.96609 ; W: -84.35918

At 45-48" lenses of coarse sand (LS)

Depth to water surface in creek: $\sim 52$ "from top of bank.

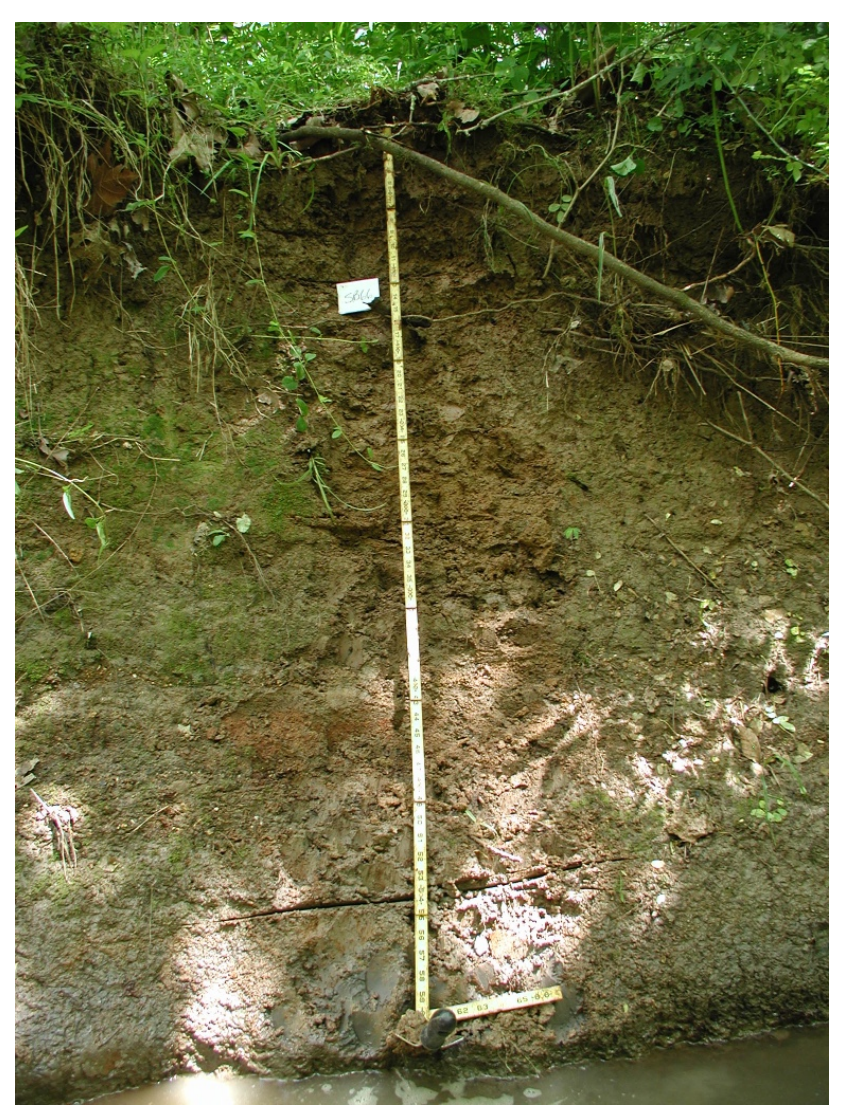

Site Evaluator's Signature 


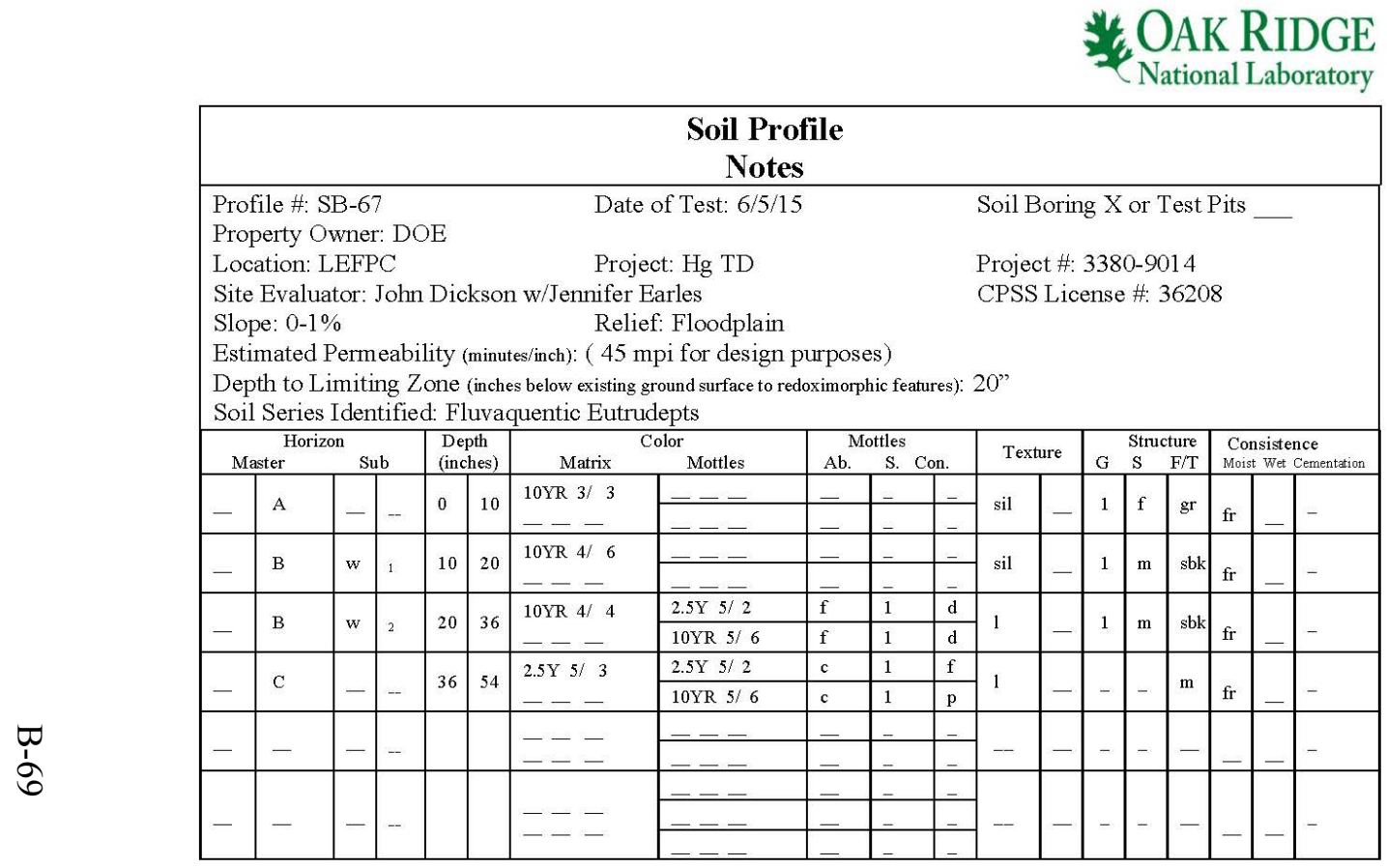

Comments:

GPS Coordinate: N: 35.96331 ; W: -84.35963

Depth to water surface in creek: 54 " from top of bank.

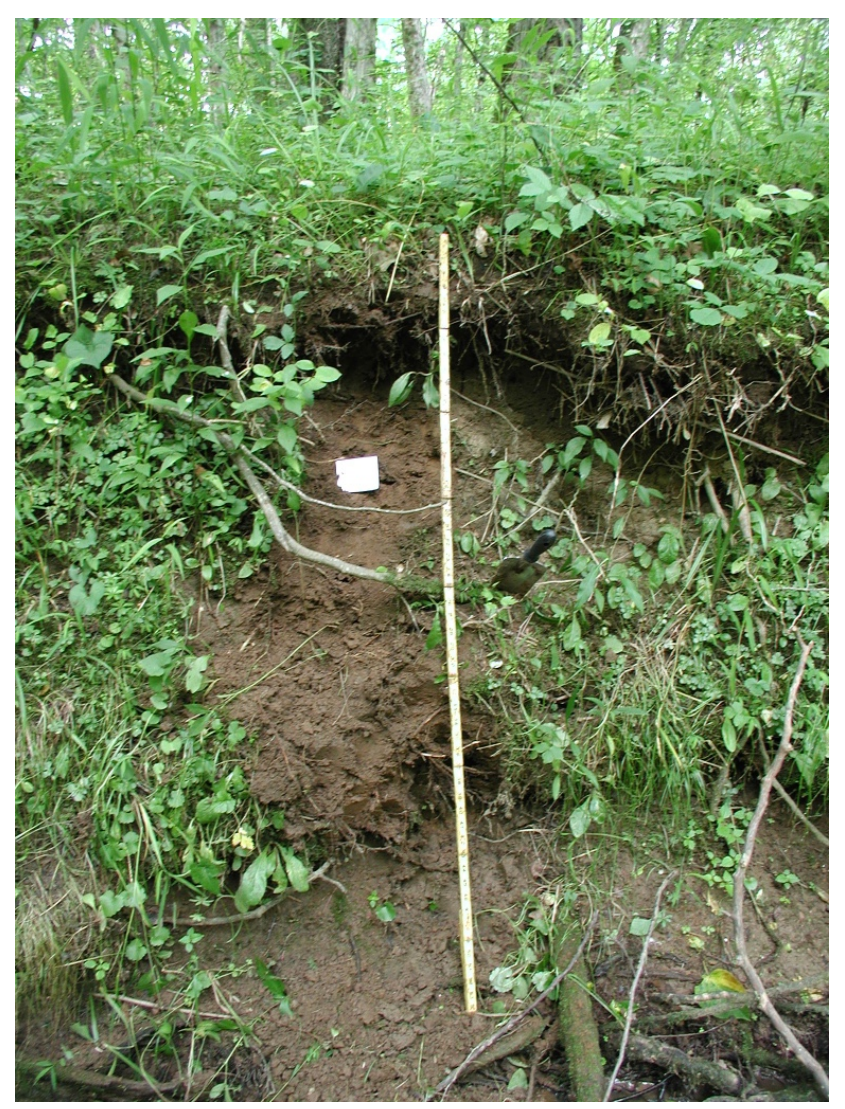

Site Evaluator's Signature: 


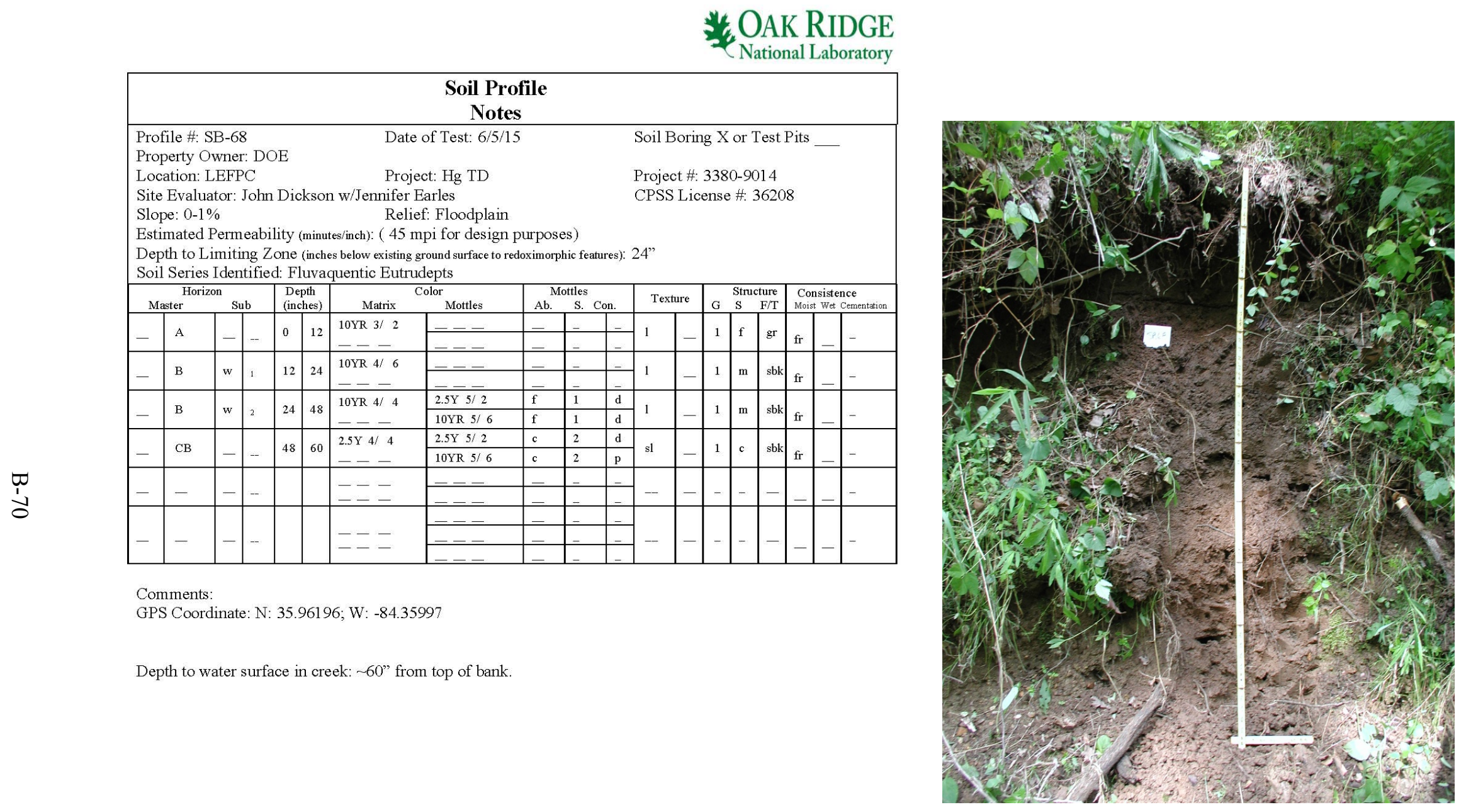




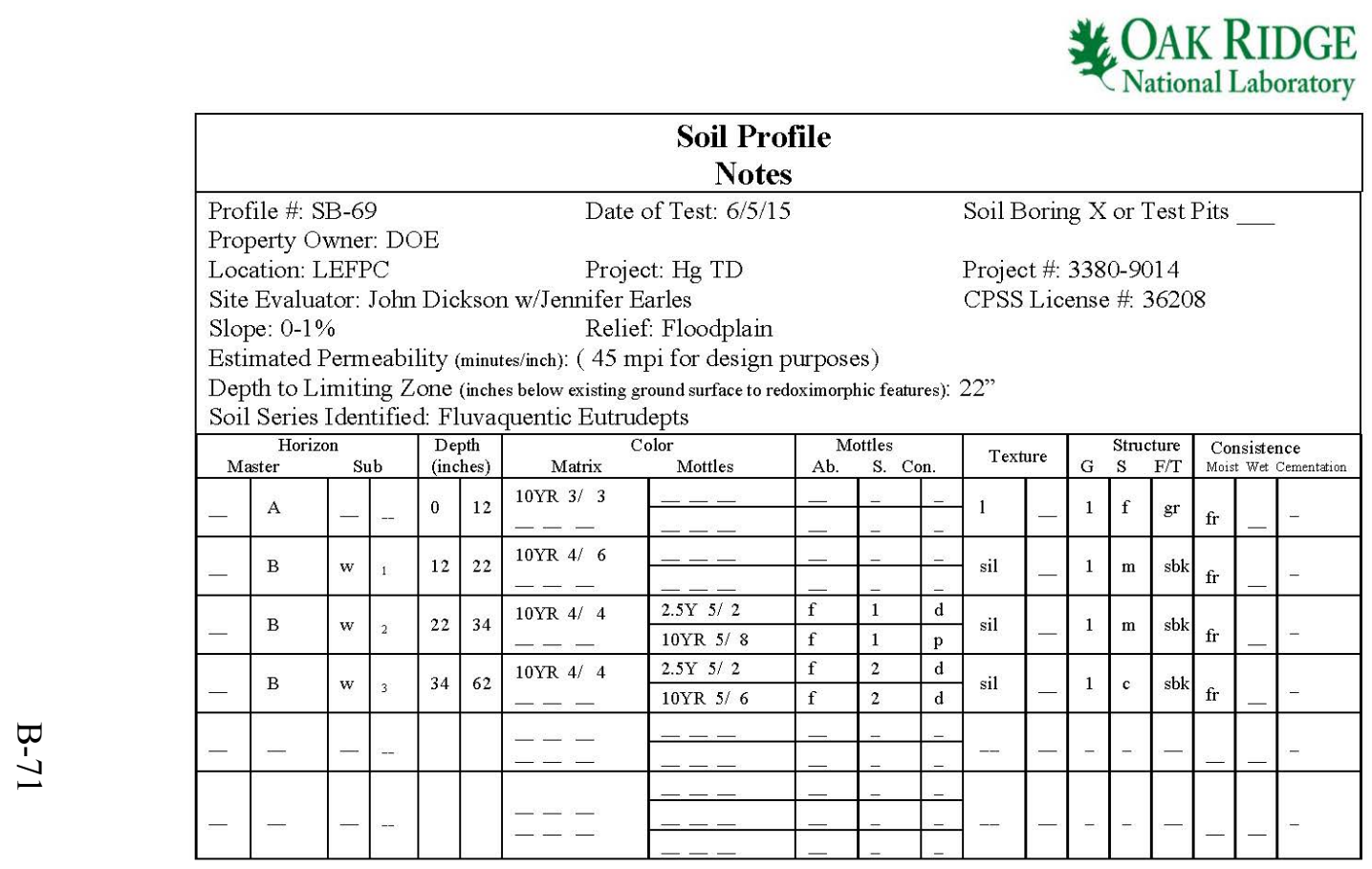

Comments:

GPS Coordinate: N: 35.96228 ; W: -84.36070

Depth to water surface in creek: $\sim 62^{\prime \prime}$ from top of bank.

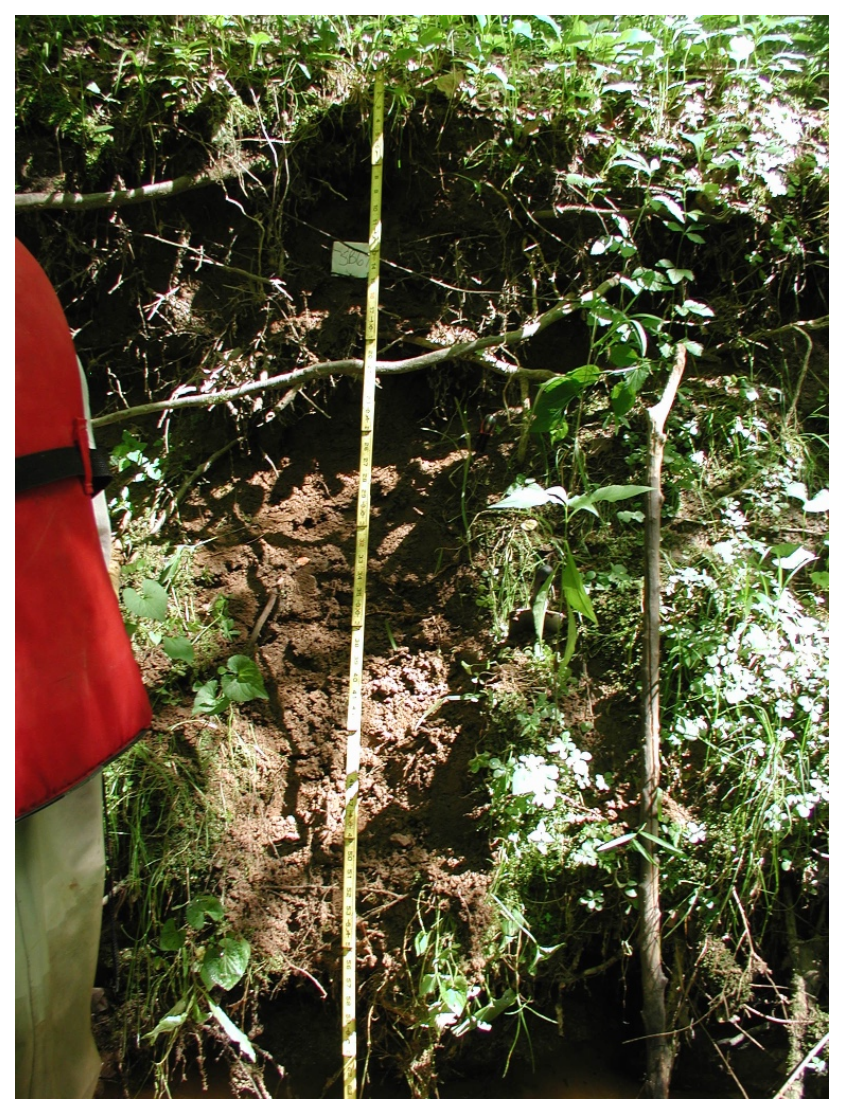





\section{APPENDIX C. BULK DENSITY SUMMARY TABLE}



APPENDIX C. BULK DENSITY SUMMARY TABLE

Table C.1. Bulk density summary table for soil mapping locations along lower East Fork Poplar Creek

\begin{tabular}{cc}
\hline Soil Map ID & $\begin{array}{c}\text { Bulk Density } \\
\left(\mathbf{g} / \mathbf{c m}^{\mathbf{3}}\right)\end{array}$ \\
\hline SB-1 & 0.984 \\
SB-5 & 0.751 \\
SB-7 & 1.329 \\
SB-8 & 1.000 \\
SB-10 & 1.321 \\
SB-14 & 1.007 \\
SB-15 & 1.467 \\
SB-19 & 1.280 \\
SB-23 & 0.914 \\
SB-24 & 1.493 \\
SB-28 & 1.315 \\
SB-32 & 1.038 \\
SB-35 & 1.116 \\
SB-38 & 1.305 \\
SB-43 & 1.259 \\
SB-45 & 1.310 \\
SB-58 & 1.391 \\
SB-61 & 1.379 \\
SB-62 & 1.223 \\
SB-63 & 1.277 \\
SB-67 & 1.386 \\
\hline
\end{tabular}


